UNIVERSIDADE DE SÃO PAULO

FACULDADE DE FILOSOFIA, LETRAS E CIÊNCIAS HUMANAS

DEPARTAMENTO DE HISTÓRIA

PROGRAMA DE PÓS-GRADUAÇÃO EM HISTÓRIA SOCIAL

\title{
CONCEPÇÕES DE HISTÓRIA E DE ENSINO \\ EM MANUAIS PARA O ENSINO MÉDIO \\ BRASILEIROS, ARGENTINOS E MEXICANOS
}

Vitória Rodrigues e Silva

São Paulo

2006 
UNIVERSIDADE DE SÃO PAULO

FACULDADE DE FILOSOFIA, LETRAS E CIÊNCIAS HUMANAS

DEPARTAMENTO DE HISTÓRIA

PROGRAMA DE PÓS-GRADUAÇÃO EM HISTÓRIA SOCIAL

\section{CONCEPÇÕES DE HISTÓRIA E DE ENSINO \\ EM MANUAIS PARA O ENSINO MÉDIO \\ BRASILEIROS, ARGENTINOS E MEXICANOS}

Vitória Rodrigues e Silva

Tese apresentada ao Programa de PósGraduação em História Social, do Departamento de História da Faculdade de Filosofia, Letras e Ciências Humanas da Universidade de São Paulo, para obtenção do título de Doutor em História.

Orientadora: Profa. Dra. Maria Lígia Coelho Prado 


\section{Resumo}

Tomando os livros didáticos como fonte de investigação e a História das disciplinas como perspectiva de análise, este trabalho tem o propósito de analisar as concepções de História e de seu ensino presentes nos livros didáticos destinados aos alunos do Ensino Médio, líderes de venda no Brasil, Argentina e México no início dos anos 2000. Produzidos após a onda de reformas curriculares verificadas na década anterior, visamos identificar em que medida essas novas proposições, bem como os debates no campo do ensino de História, influenciaram autores e editores a publicar obras sintonizadas com as mudanças propostas. Com essa análise queremos realçar a necessidade de as pesquisas em torno do ensino de História, especialmente aquelas que tomam os livros didáticos como objetos de investigação, tomarem tanto as concepções de História como as concepções sobre o ensino dessa disciplina como algo intrinsicamente integrado.

A pesquisa demonstrou que, apesar dos três países apresentarem vários traços semelhantes, tanto no tocante à realidade educacional, como do mercado editorial, os livros didáticos brasileiros, argentinos e mexicanos analisados denotam práticas bastante distintas no ensino de História. Tais diferenças decorrem de um amplo conjunto de fatores, os quais procuramos identificar.

\section{Palavras-chave}

Ensino de História - Livro didático - Concepção de ensino - Concepção de História 


\begin{abstract}
Taking textbooks as the source of investigation and the History of disciplines as the perspective for analysis, this work has the purpose of analyzing the conceptions of History and of its teaching present in textbooks aimed at High School students, which were the biggest sellers in Brazil, Argentina and Mexico in the early 2000's. Produced after the wave of curriculum reforms that took place in the previous decade, we aimed at identifying to what extent these new proposals, as well as the debates in the field of History, have influenced both authors and editors to publish works harmonized with such propositions. Through this analysis, we want to emphasize that the research on the teaching of History, especially those which have the textbook as their object of investigation, should necessarily take into account the conceptions of History as well as the teaching conceptions of this discipline as something intrinsically integrated.
\end{abstract}

The research demonstrated that, despite the fact that the three countries have shown several similar traits in relation to the educational reality as well as the editorial market, the analyzed Brazilian, Argentinian and Mexican textbooks denote very distinctive practices in the teaching of History. Such differences are due to an ample set of factors, which we attempted to indentify.

\title{
Key words
}

Teaching History - Textbook - conception of History - teaching conceptions 


\section{Resumen}

Tomando los libros didácticos como fuente de investigación y la Historia de las asignaturas como perspectiva de análisis, dicho trabajo tiene como propósito analizar las concepciones de Historia y de su enseñanza presente en los libros didácticos destinados al alumnado de Enseñanza Media, líderes de venta en Brasil, Argentina y México en inicio de los años 2000. Producidos tras la oleada de reformas curriculares ocurridas en la década anterior, pretendemos identificar en qué medida esas nuevas proposiciones, bien como los debates en el campo de la enseñanza de Historia influyeron a autores y editores a publicar obras en sintonía con tales propuestas. Con ese análisis queremos subrayar la necesidad de las investigaciones alrededor de la enseñanza de Historia, especialmente aquéllas que toman los libros didácticos como objetos de investigación, tomando tanto las concepciones de Historia como las de enseñanza de esta disciplina como algo intrínsicamente integrado.

La investigación demostró que aunque los países presenten varios trazos semejantes, en lo que se refiere a la realidad educacional, como del mercado editorial, los libros brasileños, argentinos y mexicanos que fueron analizados señalan prácticas bastante distintas en la enseñanza de Historia. Tales diferencias resultan de un amplio conjunto de hechos, los cuales buscamos identificar.

Palabras-clave

Enseñanza de Historia - libro didáctico - concepción de enseñanza concepción de Historia 
Para
Maria Aparecida, Giselle e Serafina (in memorian),

Helenice, Maria Helena

e Cleide

Mulheres sem as quais eu não seria a professora que sou.

minha mãe, Hermínia,

Sem a qual eu não seria a mulher que sou. 


\section{Sumário}

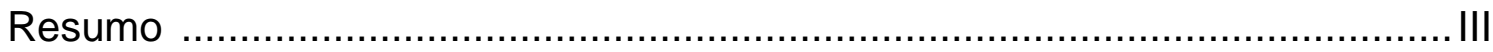

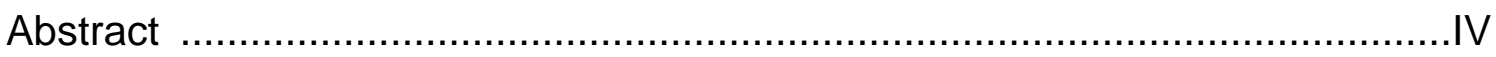

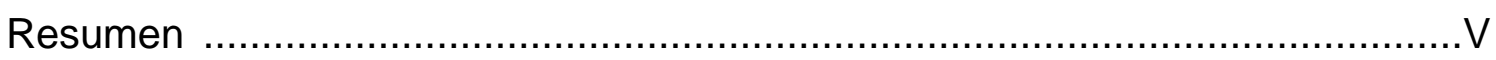

Introdução

Livro didático, concepções de História e de ensino: em busca

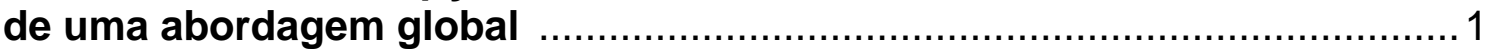

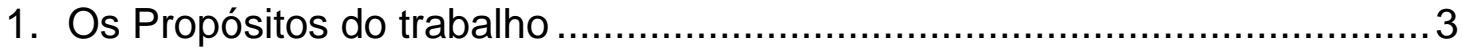

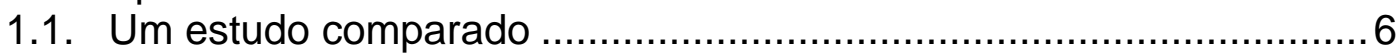

2. As Pesquisas no campo da História das disciplinas .......................... 8

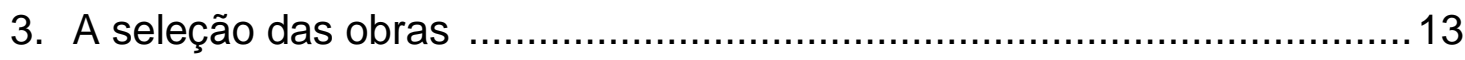

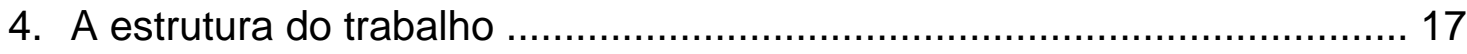

Capítulo I

Estruturas educacionais e políticas públicas para o ensino .....................20

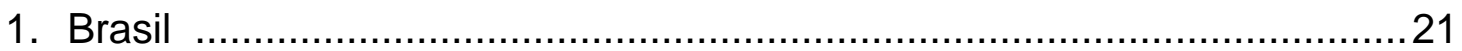

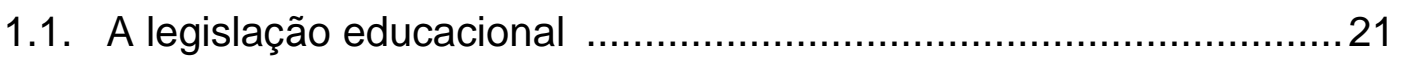

1.2. Perfil dos alunos .............................................................. 23

1.3. Perfil dos professores ....................................................... 26

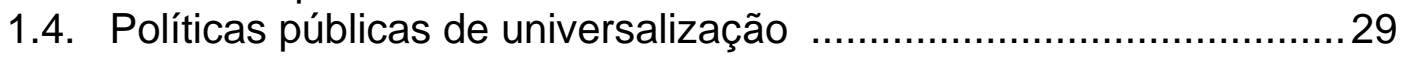

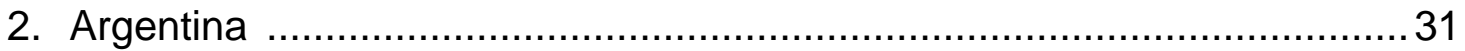

2.1. As normas legais sobre educação .......................................... 31

2.2. Políticas públicas de universalização ........................................ 32

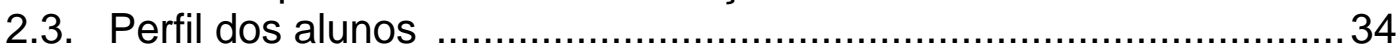

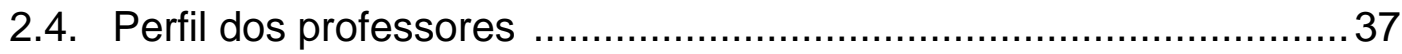

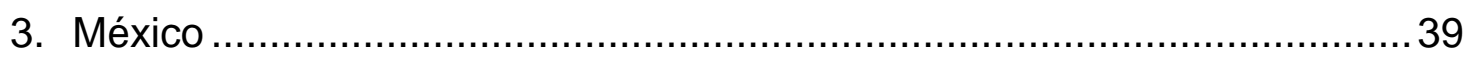

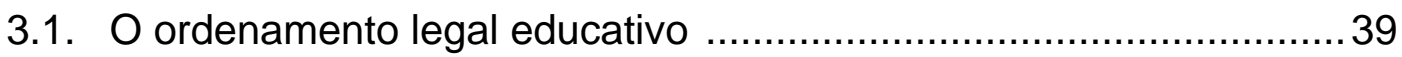

3.2. Perfil dos alunos ................................................................. 44

3.3. Perfil dos professores ......................................................... 46

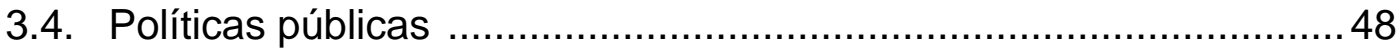

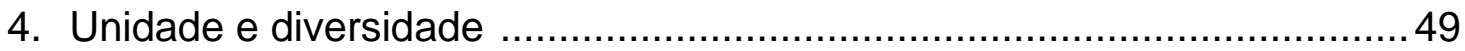


Capítulo II

Reformas educacionais e novas propostas curriculares para

o Ensino Médio: os desafios da universalização

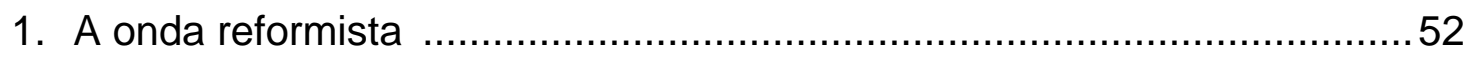

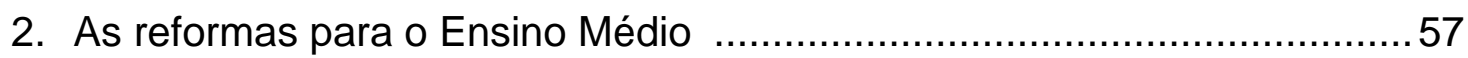

3. Brasil: Os Parâmetros Curriculares Nacionais para o Ensino Médio ..........63 63

4. Argentina: O Acordo Marco para a Educação Polimodal .........................70

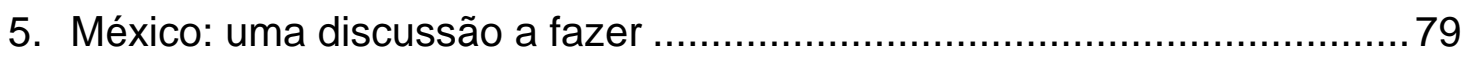

6. Currículos, propostas curriculares e a análise dos livros didáticos ...........84

Capítulo III

Os livros didáticos de História para o Ensino Médio .............................. 86

1. Os livros didáticos como fontes de pesquisa ................................... 87

2. A função dos livros didáticos ....................................................... 92

3. As pesquisas sobre o livro didático no México, Argentina e Brasil ............96

4. Os livros, os autores e as equipes editoriais ................................ 101

4.1. Os livros em seus aspectos físicos......................................... 105

4.2. Da capa para o miolo......................................................... 108

5. Introdução aos estudos históricos: começo ou recomeço? ....................118

\section{Capítulo IV}

Concepção de História e de ensino: diversidade na unidade ..................123

1. O projeto gráfico: a comunicação visual de um livro ........................... 124

2. Forma e conteúdo: concepção de História e projeto gráfico .................126

3. Iconografia: a história por meio de imagens ................................. 135

4. A abrangência dos conteúdos …............................................... 137

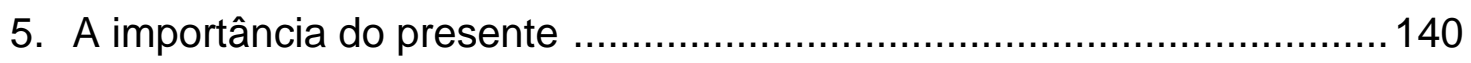

6. Revolução Industrial e lluminismo: dois tema clássicos no ensino de História ......................................................................... 146

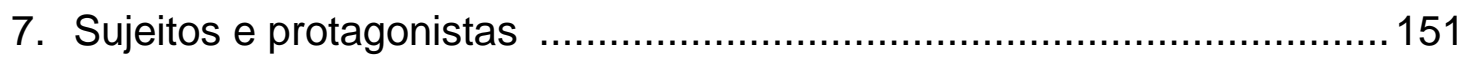

7.1. A história do século XX: eventos e nações................................ 155

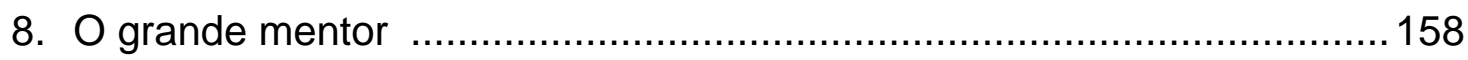

9. Diálogos com aa academia ......................................................... 161

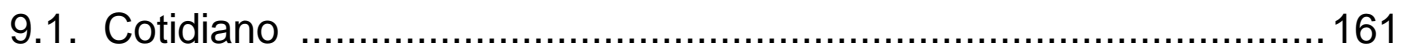

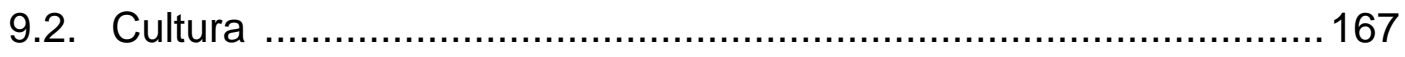




\section{Capítulo V}

Concepção de História: visões sobre a América Latina

1. O lugar da América 173

2. América Latina sob a ótica dos livros mexicanos e brasileiros 177

3. Populismo 186

4. Caudilhismo e populismo nas abordagens dos livros argentinos 192

5. Iconografia 204

6. Visões da América 207

Capítulo VI

História concebida e Historia ensinada

1. As atividades 211

1.1. A valorização das questões de aprendizagem

2. Concepções de ensino 215

3. Introdução os estudos e os conhecimentos prévios 222

4. Comparações históricas 231

5. Outros textos, outras idéias? 233

6. Leitura de imagens 235

7. Trabalho com mapas 236

8. As temporalidades 238

9. Avanços e permanências 240

Conclusão 243

1. História Geral:História da humanidade ou uma História do capitalismo? 243

2. A História como disciplina escolar 245

3. As propostas curriculares e os conteúdos dos livros 252

4. Juntando as várias pontas 255 


\section{Agradecimentos}

Houve tempo em que teses eram resultado de uma longa trajetória profissional ou acadêmica. Elas, por isso, revelavam o acúmulo de leituras, reflexões e conhecimentos tecidos ao longo de dez, quinze ou mais anos. Essa tese filia-se a essa tradição, um tanto superada, em tempos em que os títulos acadêmicos sóem ser alcançados ainda na juventude.

Por esse motivo, seria justo que nessa página de agradecimentos fossem nomeadas muitas pessoas que contribuíram de algum modo para que esse trabalho síntese de um percurso -, fosse desenvolvido. Na impossibilidade de fazê-lo, dada a extensão da lista, gostaria de citar três antigos professores da PUC-SP: em primeiro lugar, Holien Gonçalves Bezerra, mestre no sentido mais profundo que o termo pode ter e de quem, mesmo a distância, continuo a escutar a palavra de estímulo: coragem ! ; Ilana Blaj, por ter me oferecido a primeira experiência de trabalho acadêmico, como monitora em suas aulas de Brasil Colônia, e Vera Lucia Vieira por uma lição jamais esquecida: "peque pela ousadia, jamais pela omissão". Essa tese espera ser uma pequena aplicação desse ensinamento.

Sou grata a muitos colegas professores com quem pude partilhar a aventura do conhecimento nas salas de aulas de várias escolas em que trabalhei, representando a todos por meio de Pierre Chauvin, professor e amigo querido, que sempre acreditou que ser exigente é a maior lição e estímulo que podemos dar a nossos alunos e com quem aprendi o real significado do ditado " $N$ 'importe quele vache espagnole parle le français, mais ocune ne l'écrit".

Essa tese deve muito a Wilson Roberto Gambetta, e ele sabe por quê. Externo meu carinho e estima por vários colegas da Atual Editora, com quem aprendi o fascinante ofício de fazer livros didáticos. Há uma pequena porção deles nas páginas que se seguem. 
A convivência com o grupo "flutuante" do Livres, liderado pela Profa. Circe Bittencourt e pelo Prof. Kazumi Munakata possibilitou a abertura de largos horizontes sobre o trabalho com livros didáticos. As reuniões do grupo às quintas-feiras são uma prova de que vida acadêmica não precisa ser necessariamente uma fogueira de vaidades e que ela é muito melhor quando associa bom humor e companheirismo. Sou especialmente grata à Profa. Circe Bittencourt por ter me ajudado a desenvolver o projeto inicial e muitas partes desse trabalho, que algumas pessoas, do alto de sua sapiência, disseram não tratar de Educação. Foram inestimáveis as contribuições proporcionadas pelo Prof. Kazumi Munakata, sobretudo ao me franquear a participação em seu curso sobre a história dos livros e dos livros didáticos dado na PUC-SP, em 2004. Ambos forneceram ainda contribuições muito valiosas durante o exame de qualificação, que procurei incorporar na medida das minhas limitações. A interlocução e o carinho de Márcia Razzini foram sempre muito estimulantes.

Igualmente estimulantes foram os encontros do grupo de estudos sobre América Latina, coordenados pelo Profa. Maria Lígia Prado, durante os quais pude perceber quão ricos de possibilidades podem ser esses estudos e como jovens pesquisadores têm trazido contribuições importantes por meio de suas abordagens inovadoras e ousadas. Agradeço o carinho com que fui recebida por todos.

Colegas do UNIFAI foram valiosos em muitos momentos, oferecendo esclarecimentos em áreas pouco familiares, indicando ou emprestando livros, com palavras de estímulo ou em simples conversas animadas durante o cafezinho, aliviando 0 peso do trabalho cotidiano. Externo meu especial carinho à Profa. Kátia Maria de Mendonça Curtis, por ter aberto as portas da instituição para meu ingresso, acreditando que eu poderia integrar "seu" departamento, tratado com tanta diligência. Boa parte das inquietações que motivaram esse trabalho nasceu ou cresceu no convívio com meus alunos no curso de Licenciatura de História daquela instituição.

Tudo isso, porém, não teria sido possível se não fosse a grandeza e generosidade da Profa. Maria Lígia Coelho Prado. Todas as folhas de papel me seriam insuficientes para descrever o meu prazer, o meu orgulho e o meu agradecimento em poder trabalhar com ela por mais de dez anos. Nossas vidas se cruzaram em 1995, quando começamos a trabalhar juntas em uma coleção de livros, coordenada por ela e pela Profa. Maria Helena Capelato. Eu era uma aprendiz de editora e ela, o que todos 
sabemos. Apesar das abissais distâncias ente nossas experiências e conhecimentos, o contato sempre foi fácil e prazeroso. Enfrentamos as mais variadas situações, mas sempre tivemos a mais perfeita sintonia no modo de enfrentá-las. A admiração profissional pôde se tornar também pessoal ao longo dos quatro anos em que essa tese foi desenvolvida. Procurei sempre dar o melhor de mim, como forma de retribuir sua atenção, respeito, carinho. Atenção, carinho e respeito, aliás, conferidos a todos seus orientandos, sempre, em qualquer circunstância. Essa experiência foi um privilégio e, repetindo as palavras de uma colega, digo que a melhor forma que posso encontrar para retribuir tudo o que Maria Lígia me proporcionou é me espelhar em sua integridade pessoal e em seu trabalho, procurando propagar os seus ensinamentos e a sua alegria em ensinar.

Este trabalho estava prestes a ser finalizado quando a vida resolveu me proporcionar o aprendizado de mais algumas lições. Essas, porém, não estavam escritas em nenhuma página de livro, tese ou revista, não puderem ser aprendidas em nenhuma reunião, debate ou seminário.

Ter controle sobre as coisas e o tempo é um traço meu marcante. E nada me é mais fundamental do que a minha independência. No entanto, tive que reaprender que isso é pura ilusão. O acaso, as circunstâncias, o inesperado promove em minutos uma reviravolta na vida e nos vemos sem controle de nada, senhores dos tempos estabelecidos pelos outros, dependentes para realizar os atos mais banais.

Essas lições teriam sido muito mais duras de aprender se não fossem o carinho e a competência do Dr. José Roberto Caldeira, sua equipe e colegas do Hospital Amaral Carvalho, de Jaú. Sou a todos muito grata, do mesmo modo que aos meus companheiros da Editora Positivo, em particular ao Prof. Durval Tavares, com os quais em poucas semanas pude estabelecer vínculos que às vezes uma década não são suficientes para se criar. Agradeço a meus amigos - presença solidária de força inestimável - especialmente à Clô, à Renata e à Maria Luíza, amigas de muito tempo e do fundo do coração.

Sem a atenção e o carinho do Flávio, da Sílvia, da Lídia, da Alice e de minha mãe, tudo teria sido infinitamente mais difícil. 


\title{
LIVRO DIDÁTICO, CONCEPÇÕES DE HISTÓRIA E DE ENSINO: EM BUSCA DE UMA ABORDAGEM GLOBAL
}

\begin{abstract}
Pela sua própria natureza, portanto, a história dos livros deve operar em uma escala internacional e com método interdisciplinar. Mas não precisa ser privada de uma coerência conceitual, porque os livros fazem

parte de circuitos de comunicação que funcionam segundo modelos homogêneos, por mais complexos

que sejam. Examinando esses conceitos, os

historiadores podem mostrar que os livros não se limitam a relatar a história: eles a fazem.
\end{abstract}

Robert Darton, O que é a história dos livros?

Não é recente a atenção sobre o ensino de História. A rigor, desde a constituição dos sistemas escolares públicos, que ganharam impulso no início do século XIX, o ensino de História constitui tema de discussão, dado o papel dessa disciplina no currículo escolar: contribuir fortemente para formação de uma identidade nacional, difundindo um repertório de informações, valores e imagens que constituam o alicerce da cidadania. Seu caráter ideológico, portanto, é explícito, bem como sua dimensão política. Não por acaso, vez por outra o tema torna-se motivo de debates nacionais acalorados, justificados por se tratar de assunto ligado à formação das jovens gerações. Na França e na Espanha, por exemplo, os debates foram bastante intensos nos anos 1980, quando teve curso mudanças curriculares.

Como objeto de estudo acadêmico, o ensino de História também há tempos merece atenção, abordado a partir de várias perspectivas. 
No âmbito da história da educação, tem sido objeto de investigação de estudiosos em várias partes do mundo. A obra de Evelyne Hery ${ }^{1}$, é um ótimo exemplo, tratando do caso francês, assim como Raimundo Cuesta Fernandez realiza esforço parecido, com relação à Espanha ${ }^{2}$. No Brasil, a pesquisa de Circe Bittencourt ${ }^{3}$ tornou-se referência para muitos outros trabalhos. Nesses estudos, tem se procurado resgatar as práticas escolares, recuperando informações sobre os materiais usados em sala de aula, especialmente os livros, os procedimentos usuais em classe, como a leitura e a recitação, os temas mais recorrentes, dentre outros aspectos. Quando enfocados desde uma perspectiva de longa duração, tais estudos possibilitam a identificação de costumes e tradições, bem como as lentas transformações processadas nas práticas pedagógicas. A propósito, vale lembrar que inicialmente os conteúdos de História se confundiam com os da História religiosa, e foi lento o processo de separação desses conteúdos, até resultar na configuração que hoje conhecemos para essa disciplina, geralmente estruturada a partir de temas da História pátria mais ou menos articulados com temas da História geral, também denominada História da civilização ou universal.

Outro âmbito bastante privilegiado é o referente aos aspectos teóricometodológicos. Há estudos que procuram investigar as concepções de História que marcaram essa disciplina escolar, com especial ênfase no caráter ideológico de tais concepções. Nesses casos, o foco central era a análise dos conteúdos. Especialmente nos anos 80 do século XX, foi muito forte a corrente liderada por Pierre Bourdieu, conhecida como reprodutivista, que denunciava o caráter inerentemente conservador da educação, especialmente a escolar, na medida que era sua função precípua assegurar a manutenção do status quo social. Mais recentemente, vêm ganhando impulso estudos que seguem as proposições de Jörn Rüsen, em torno do que ele chama de razão histórica e de pensamento histórico ${ }^{4}$. De corte epistemológico, essa vertente discute questões ligadas à

${ }^{1}$ Hery, Evelyne. Un siècle de enseigne au lycée 1870 - 1970. Rennes: Presses Universitaires de Rennes, 1999.

${ }^{2}$ Cuesta Fernandez, Raimundo. Sociogénesis de una disciplina escolar: la Historia. Barcelona: Ediciones Pomres-Corridor, 1997.

${ }^{3}$ Bittencourt, Circe Maria F. Livro didático e conhecimento histórico: uma história do saber escolar. Faculdade de Filosofia, Letras e Ciências Humanas da Universidade de São Paulo, 1993. Tese de doutoramento.

${ }^{4}$ Rüsen, J. Razão Histórica - Teoria da história: fundamentos da ciência histórica. Brasília: UnB, 2001. 
narrativa histórica, associando linguagem, lógica e cognição, e vem ganhando adeptos no Brasil.

Numa outra vertente, muitos pesquisadores privilegiaram questões metodológicas do ensino, voltando-se para uma variedade de aspectos, especialmente os ligados à didática. Esses estudos têm ganhado mais consistência, indo além dos relatos de experiências mal ou bem sucedidas. Mencione-se ainda $o$ fato de que nas últimas duas décadas cresceu a preocupação em se explorar - de modo crítico - novos recursos tecnológicos, em particular os de mídia, visando tornar mais dinâmico e interessante o ensino de História, quebrando assim a longa tradição das aulas expositivas, centradas no professor e assentadas em leituras, resumos e questionários. Essas preocupações de certo modo refletiam os questionamentos que os pesquisadores acadêmicos fizeram, sobretudo no pós-guerra, no sentido de ampliar os horizontes da sua própria ciência, alargando as fontes e os temas e alterando as abordagens dos trabalhos.

Uma terceira linha de investigação, bem menor, ressalve-se, é aquela que se dedica a compreender os processos de aprendizagem próprios do ensino de História. Muitas vezes esses estudos não são realizados por historiadores, mas por pedagogos e psicólogos, o que por um lado ressalta o caráter interdisciplinar dos trabalhos nessa linha e por outro indica o pouco interesse dos historiadores nesse campo ${ }^{5}$.

\section{OS PROPÓSITOS DO TRABALHO}

Este estudo soma-se ao esforço realizado por muitos pesquisadores que desde os anos 1980 vêm promovendo uma importante mudança nas investigações em História da Educação, adotando a perspectiva da História das disciplinas. Esse trabalho procura, assim, contribuir para a construção de uma

5 Os estudos realizados segundo a metodologia própria da Psicologia, em que se observa o comportamento dos alunos em dadas situações, rigidamente estabelecidas a partir de protocolos de pesquisa, associada à perspectiva piagetiana de desenvolvimento adotada na maior parte desses estudos, ainda oferece limitações para que suas conclusões possam ser generalizadas e reverter em efetiva mudança metodológica nas salas de aula. Ainda assim, os trabalhos de Isabel Barca, Peter Lee e outros pesquisadores dedicados à compreensão de como se constrói o pensamento histórico têm oferecido importantes contribuições sobre como se constrói o pensamento histórico. 
História do ensino de História, tomando como objeto de análise livros didáticos produzidos nos primeiros anos do século XXI. Nosso propósito é identificar alguns traços desse ensino no presente, procurando verificar em que medida essas obras incorporam algumas das discussões acima mencionadas, sobretudo depois das reformas curriculares processadas durante os anos 1990.

Estando envolvida com o ensino de História há mais de 20 anos - como professora da Educação Básica e, depois, do Ensino Superior - , e com os livros didáticos há mais de 10 - como autora e como editora - algumas questões me intrigavam à época em que esse trabalho foi concebido: as reformas curriculares e os debates sobre educação em geral, e sobre o ensino de História em particular, teriam promovido mudanças nas concepções de História e do seu ensino nas obras recentemente editadas e destinadas aos alunos brasileiros do Ensino Médio? Minha experiência profissional indicava diferenças marcantes entre a produção destinada ao Ensino Fundamental e aquelas feitas para a etapa posterior de escolaridade. Se esses debates tinham uma abrangência internacional, levando muitos países a realizar reformas curriculares, seria possível, por meio de uma análise comparativa, identificar novas tendências nas abordagens presentes nos manuais escolares?

Essas questões envolvem uma série de aspectos: propostas e projetos educacionais, políticas educacionais nacionais e mundiais, currículo e reformas curriculares, o livro didático como artefato cultural e industrial, várias facetas do ensino da História, como a seleção dos conteúdos, a influência das novas temáticas e das novas abordagens na produção historiográfica, o trabalho com as temporalidades históricas, as questões de aprendizagem, entre outros. Interessava-me desde o início investigar essas questões de um modo abrangente e integrado. Leituras e discussões com outros pesquisadores me fizeram ver que a perspectiva da História das disciplinas seria capaz de proporcionar tal abordagem, por fornecer elementos que nos possibilitariam articular esses vários aspectos, muitas vezes tomados de modo estanque, o que nos parecia indevido. Foi a partir dessa perspectiva, pois, que desenvolvemos a pesquisa. 
Como observa Thaís Fonseca ${ }^{6}$, investigar o ensino a partir dessa plataforma é tarefa bastante desafiadora, exigindo o esforço conjugado a muitos pesquisadores, uma vez que obriga ao estudo de diversas temáticas, como as relações entre as propostas de ensino e as políticas educacionais adotadas, os sistemas de avaliação, os métodos de ensino, as propostas curriculares, os conteúdos ensinados e suas formas de apropriação, as práticas docentes, os materiais didáticos utilizados, as políticas públicas de avaliação e distribuição de livros didáticos, dentre outros aspectos. Ainda que a opção de tomar como objetos de investigação os livros didáticos naturalmente implicasse certos limites para a caracterização do ensino da disciplina, e mesmo considerando que as condições de realização da pesquisa inviabilizava a inclusão de uma etapa de averiguação de como essas obras são utilizadas em sala de aula, o problema a ser enfrentado parecia instigante e relevante. Sabemos que mudanças nos livros didáticos não representam necessariamente alterações nas práticas de sala de aula, assim como é possível que mudanças nas práticas docentes não promovam necessariamente transformações nos manuais. No entanto, sabemos que essas obras desempenham um papel relevante nas práticas escolares, e pela própria dinâmica da sua produção é possível reconhecer uma certa sintonia entre o que elas apresentam e o que é ensinado em classe. Por isso, tomamos como pressuposto que por meio desses materiais é possível captar algumas das concepções de História e de seu ensino que circulam no meio escolar e, conseqüentemente, perceber se elas apontam para novos rumos. Segundo Chervel, "dos diversos componentes de uma disciplina escolar, o primeiro na ordem cronológica, senão na ordem de importância, é a exposição pelo professor ou pelo manual de um conteúdo (sic) de conhecimentos. É esse componente que chama propriamente a atenção, pois é ele que a distingue de todas as modalidades não escolares de aprendizagem, as da família ou da sociedade. Para cada uma das disciplinas, o peso específico desse conteúdo explícito constitui uma variável histórica cujo estudo deve ter um papel privilegiado na história das disciplinas escolares. É uma variável que, em geral, põe em evidência algumas grandes tendências: evolução que vai do curso ditado para a lição aprendida no livro, da formulação estrita, até mesmo lapidar, para as exposições mais flexíveis, da recitação para a impregnação, da exaustividade para a seleção das linhas principais. [...] A tarefa primeira do historiador das disciplinas escolares é estudar os conteúdos explícitos do ensino disciplinar. [...] todas as disciplinas, ou quase todas, apresentam-se sobre este plano 
como corpus de conhecimentos, providos de uma lógica interna, articulados em torno de alguns temas específicos, organizados em planos sucessivos claramente distintos e desembocando em algumas idéias simples e claras, ou em todo caso encarregadas de esclarecer a solução de problemas mais complexos" ${ }^{\prime 7}$. Com base nesse pressuposto, tomamos como hipótese inicial que a produção editorial pósreformas curriculares, transcorridas em um contexto de intensos debates tanto no plano educacional como entre os historiadores, forneceria um conjunto de fontes de investigação bastante rico para o desenvolvimento de uma análise dentro desses marcos teóricos. E como as reformas tinham sido implementadas em muitos países, parecia interessante observar como alguns deles tinham encaminhado as propostas de ensino de História e, conseqüentemente, como o mercado editorial tinha respondido a esse novo quadro.

\subsection{Um estudo comparado}

Desde o início, portanto, procuramos realizar um trabalho em perspectiva comparada, pois imaginávamos que assim seria possível captar um movimento mais amplo no ensino da História, indo além da realidade brasileira. Circunstâncias nos encaminharam a privilegiar casos latino-americanos, recaindo a escolha nos livros mexicanos e argentinos. Isso não se deveu apenas ao fato de que ambos os países tinham passado recentemente por reformas curriculares, mas também porque seus sistemas de ensino abarcam um enorme contingente de alunos, sem, contudo, atingir a universalização dessa etapa da escolarização, e seus mercados editoriais são bastante desenvolvidos ${ }^{8}$. Trata-se, pois, de três países que apresentam características educacionais semelhantes, e para os quais o problema que pretendíamos investigar estava claramente posto. Essa configuração, sabíamos, é condição necessária para um estudo comparativo ${ }^{9}$,

7 Chervel, André. "História das disciplinas escolares: reflexões sobre um campo de pesquisa". In Teoria \& Educação no. 2. 1990. p. 202-203.

8 Inicialmente havia ainda um outro fator que fazia a comparação parecer ainda mais interessante: a informação de que no México vigora uma política de livros únicos, produzidos e oferecidos pelo próprio governo. No entanto, a medida que a pesquisa foi avançando, viemos a saber que essa política constitui elemento central no nível fundamental mas não é aplicada no nível médio; os livros destinados a esse público são produzidos por editoras privadas, ainda que necessitem de aprovação governamental para circularem, e são os professores que os escolhem, indicando-os para compra .

9 Maria Lígia Prado, em um recente artigo, retoma um tema que lhe é caro, dos estudos históricos comparados, realçando como aspecto central nessa metodologia a definição clara de um problema, que, abordado de modo comparativo, ajuda a compreender melhor cada caso individual e promove uma visão mais abrangente do mesmo. Prado, Maria Lígia C. "Repensando a História comparada da América Latina". Revista de História no. 153, 2 sem. 2005. 
uma vez que a pesquisa não se propunha apresentar três situações de ensino de História, aferindo ao final semelhanças e diferenças. O objetivo era mais ambicioso: entender como o contexto educacional de cada país, apresentando de início diversos aspectos comuns, repercute no modo como o ensino de História é realizado; para tanto, tomaria-se os livros didáticos como veículos difusores de certas concepções de História e do seu ensino, procurando verificar como tais obras atenderiam, ou não, as novas propostas curriculares.

A investigação a ser realizada desde logo demonstrou a necessidade de se reunir um grande conjunto de variáveis, às quais os livros didáticos estão relacionados. Esforço ainda maior por exigir que tal levantamento fosse feito considerando a situação dos três países e por não se encontrar no levantamento bibliográfico realizado nenhuma investigação semelhante. Os desafios, portanto, foram enormes.

O levantamento bibliográfico que realizamos apontou outro ponto relevante: a existência de um expressivo número de trabalhos sobre o ensino de História no nível Fundamental, vários deles, inclusive, tomando o livro didático como uma das fontes ou mesmo como objeto central de investigação, mas um número muitíssimo menor de estudos que tem o Ensino Médio como foco ${ }^{10}$. Essa lacuna possivelmente seja explicada pelo fato de que só muito recentemente uma maior parcela de jovens começou a atingir e concluir essa etapa da Educação Básica, tornando-se alvo de preocupação dos educadores. Além disso, a esmagadora maioria dos trabalhos na área da Educação (Pedagogia, Psicologia da aprendizagem e outros), onde muitas dessas pesquisas são realizadas, dedica-se predominantemente ao estudo dos vários ciclos do Ensino Fundamental, especialmente os primeiros, havendo menor interesse sobre o processo de aprendizagem a partir dos 15 anos.

Pessoalmente, porém, meu interesse sobre essa etapa escolar cresceu durante a segunda metade dos anos 1990. Atuando como editora de livros didáticos e como professora de metodologia do ensino de História, sentia falta de maiores subsídios para o meu trabalho nesses dois âmbitos. Além disso,

10 Essa constatação não foi feita apenas em relação ao Brasil, mas também nos casos mexicano e argentino. 
considero muito falaciosa uma idéia bastante recorrente, de que as maiores dificuldades no ensino de História são enfrentadas pelos alunos com menor idade, até por volta dos 14 anos, uma vez que a partir dessa idade seu processo de desenvolvimento cognitivo o habilitaria a raciocínios abstratos mais complexos. Minha experiência me fornece inúmeros exemplos de como, até mesmo para adultos, a natureza do pensamento histórico é complexa e considerada bastante difícil. Minha trajetória profissional, a propósito, marca profundamente essa pesquisa. Ela revela muitas das inquietações que fui tendo ao longo dos últimos 25 anos, atuando como professora, assessora pedagógica, autora de materiais didáticos e editora, em que se entrecruzaram questões sobre a construção do conhecimento em geral e do conhecimento histórico em particular, questões teóricas da ciência histórica e sua conversão para o plano pedagógico, a natureza do discurso didático e da compreensão leitora. A tentativa de articular todos esses campos, ao mesmo tempo que me parecia instigante, me possibilitava uma reflexão sobre meu próprio caminho como historiadora-professora-editora.

\section{AS PESQUISAS NO CAMPO DA HISTÓRIA DAS DISCIPLINAS}

Thaís Fonseca, no livro já mencionado, faz uma boa síntese dos estudos realizados sobre o percurso da constituição da História como disciplina escolar no Brasil desde o século XIX - um campo, aliás, que até os anos 1990 era incipiente no país. Um aspecto interessante da obra é que ao caracterizar o percurso da disciplina, ela, ao mesmo tempo em que fundamenta teoricamente o seu texto, aponta os principais autores que têm fornecido os marcos teóricos segundo os quais esse campo de investigação tem avançado entre nós, como André Chervel, Jean-Claude Forquin, Dominique Julia e outros.

Não cabe aqui reapresentar essa trajetória, mas é preciso destacar um ponto relevante: o estudo das disciplinas escolares tem se desenvolvido a partir dos referenciais da história cultural, vale dizer, considera as disciplinas como parte integrante de um conjunto de práticas sociais associadas à escola. O conjunto de saberes escolares que a constitui é resultado de uma série de relações e embates travados no âmbito da educação e mesmo da sociedade como um todo. Não se trata, portanto, de uma simples seleção de conteúdos, a partir dos conhecimentos da ciência de referência, a serem ensinados às novas gerações. Tampouco as

disciplinas são resultantes da aplicação direta de dispositivos legais, como os 
currículos oficiais, portarias e leis. Entram em jogo na sua definição as funções sociais a que se atribui à escola, as vivências e experiências dos professores e também dos alunos, os recursos que se dispõe, entre eles os livros didáticos. Entram em jogo, igualmente, aspectos políticos e ideológicos, tanto internos como externos ao mundo escolar. A História das disciplinas, ao fixar esses pressupostos, distancia-se de uma concepção de História da Educação presa apenas os parâmetros oficiais e, portanto, distante da prática escolar efetiva. Ao filiar-se à concepção cultural da História, compartilha um referencial teórico que tem animado inúmeros estudos historiográficos em outros campos, como o da História Social e da História Política.

Como observa Fonseca, ao escolher os conteúdos - um aspecto fundamental na constituição das disciplinas escolares -, os autores dos livros didáticos, ainda que possam ter alguma autonomia, o fazem a partir de seleções culturais de saberes, marcadas pelas estruturas e pelos valores sociais vigentes. São, conseqüentemente, seleções historicamente dadas. Citando Forquin, ela afirma: "Esses saberes e a constituição das disciplinas escolares que a eles correspondem estariam ligados, assim, a condicionantes sociais, não somente em sua elaboração como em sua aplicação pedagógica, considerando os grupos que os concebem e para os quais os concebem"11. Apesar desses conhecimentos estarem referenciados às áreas de conhecimento acadêmico, Chervel alerta para a necessidade de se reconhecer como eles devem ser entendidos como criação da escola, na escola e para a escola ${ }^{12}$.

Sem nos alongarmos nessa questão da transformação dos conhecimentos acadêmicos em conhecimentos escolares, vale mencionar as duas principais vertentes de análise. De um lado estão aqueles que, concordando com Yves Chevallard $^{13}$, consideram que essa transformação se dá por meio de uma transposição didática, ou seja, por meio de uma série de operações metodológicas embasadas em fundamentos pedagógicos que "traduziriam" ao nível dos alunos os conhecimentos considerados mais relevantes da(s) ciência(s) de referência, visando a formação desses indivíduos; de outro, encontramos aqueles que consideram esse processo mais complexo, uma vez que os fatores

11 Fonseca, Thais N. L Op. cit. p. 17.

12 Chervel, A. Op. cit . p. 181.

13 Chevallard, Y. Transposition didatique. Grenoble: La Pensée Sauvage, 1991. 
que interferem na constituição dos saberes escolares são mais numerosos, sendo eles tanto internos como externos ao próprio âmbito educacional. As disciplinas, afirma André Chervel, são "criações espontâneas e originais do sistema escolar"14, e por isso mesmo deve-se inserir seu estudo no interior da cultura escolar, reconhecendo sua autonomia, superando assim uma visão que predominou bastante tempo, segundo a qual as disciplinas, e a própria escola, teriam apenas um papel ideológico, reprodutor da ordem vigente. Nosso estudo adota essa segunda perspectiva, por entender que ela compreende um conjunto mais amplo de aspectos e possibilita melhor entendimento do processo de constituição e reformulações das disciplinas escolares.

Ivor Goodson ${ }^{15}$, tratando mais especificamente da constituição dos currículos escolares, observa que eles têm uma fase pré-ativa - quando são ainda formulações formais, em geral prescritivas, vindas de alguma autoridade (comissões de especialistas, órgãos oficiais, etc.) - e uma fase interativa quando eles entram em ação. A passagem de uma fase para outra não é direta, fácil ou mesmo obrigatória. Apenas para dar um exemplo, as propostas curriculares definidas pela Secretaria de Educação do Estado de São Paulo nos anos 1980, fundadas, no caso de História, no estudo a partir de eixos temáticos, jamais foram implantadas em muitas escolas da rede estadual, por vários motivos, entre eles a dificuldade de muitos professores em desenvolver o trabalho conforme as orientações oficiais ${ }^{16}$. Ainda assim, observa aquele autor, "a constituição pré-ativa pode estabelecer parâmetros importantes e significativos para a execução interativa em sala de aula "17. Muitas vezes, a publicação de um currículo ou de uma proposta curricular pode ser apenas um momento de um longo conflito, envolvendo vários setores sociais.

${ }^{14}$ Chervel, A. Op cit. p. 184. Diz ainda o mesmo autor: " A disciplina escolar é então constituída por uma combinação, em proporções variáveis, conforme o caso, de vários constituintes: um ensino de exposição, os exercícios, as práticas de incitação e de motivação e um aparelho docimológico [relativo à avaliação], os quais, em cada estudo da disciplina, funcionam evidentemente em estreita colaboração, do mesmo modo que cada um deles está, a sua maneira, em ligação direta com sua finalidade. Idem, p. 207.

15 Goodson, I. Currículo: teoria e história. Petrópolis: Vozes, 1995.

16 Uma boa análise dos embates que envolveram as propostas curriculares entre os anos 1970 e 1990 em São Paulo encontra-se em Cordeiro, Jaime. A História no centro do debate: da crítica do ensino ao ensino prático.São Paulo: Cultura Acadêmica, 2000 e em Fonseca, Selva. Os caminhos da História Ensinada. Campinas, Papirus, 1983.

17 Goodson, Ivor. Op. Cit. p. 24. 
Os livros didáticos, nesse aspecto, desempenham um duplo papel. Eles, por um lado, expressam uma determinada visão de currículo (tributária ou não de prescrições oficiais) e, ao mesmo tempo, constituem uma proposta curricular. Ou seja, eles expressam uma certa concepção de escola, de disciplina e de conhecimento e ao mesmo tempo ajudam a forjar, em cada sala de aula, uma certa prática curricular, que eventualmente pode até mesmo subverter a concepção inicial. Isso pode ocorrer, por exemplo, quando, ao apresentar um certo tema, o livro propõe que seja visto um vídeo (filme ou documentário) ou lido um texto literário, a partir do qual alunos e professores podem romper com 0 percurso sugerido pelo próprio livro, abrindo espaço para outras temáticas e dinâmicas pedagógicas.

Isso revela como os livros didáticos caracterizam-se, ao mesmo tempo, por uma estrutura em geral bastante rígida, que lhe é própria ${ }^{18}$, mas que não necessariamente gera um engessamento do trabalho pedagógico. Eles em geral constituem um campo de possibilidades (sempre a serviço de alguma intenção) e um dos objetivos desse trabalho foi verificar quais as possibilidades que os livros analisados oferecem, explícita ou implicitamente, colaborando, assim, para que certas vivências por parte dos alunos, os ajudem a construir uma dada concepção de História (que não é, entretanto, tarefa exclusiva da escola).

Nos estudos sobre livros didáticos de História, a grande maioria dos autores toma os livros nacionais como objeto de estudo, ainda que com o objetivo de discutir os mais variados problemas. São recorrentes, por exemplo, análises que buscam estabelecer relações entre ensino de História, a consolidação das nacionalidades e a difusão de uma certa memória histórica, na qual o Estadonação ocupa papel de sujeito privilegiado, o que explicaria porque imperou, por tanto tempo, uma História escolar essencialmente política, centrada nos heróis nacionais $^{19}$. Predominam, pois, estudos em que os autores investigam a produção didática de seus próprios países. A presente pesquisa, como dissemos, propõe

${ }^{18}$ É próprio de um livro didático organizar-se dentro de uma estrutura formal rígida, que se repete ao longo de todo o volume ou coleção, geralmente constituída de partes, unidades, capítulos e seções. Essa composição não implica que necessariamente o professor em sala de aula tenha que seguir com a mesma rigidez essa estrutura ou mesmo que tenha de respeitar a seqüência proposta. Muitos livros são concebidos com explícita preocupação de poder ser utilizado de muitos modos.

19 Dentre os muitos autores que trabalham nessa perspectiva, podemos citar, na produção brasileira, Circe Bittencourt, Arlete Gasparello, Selma Mattos. Suzane Citron e Annie Brüter na França, Nikita H. Vallenilla na Venezuela, Fernando Catroga em Portugal, Raimundo Cuesta Fernandez na Espanha são outros exemplos, no âmbito internacional. 
um estudo comparado ${ }^{20}$. Essa escolha exigiu privilegiar a análise dos livros de História Geral, uma vez que resultaria em tarefa bastante difícil comparar livros cujos conteúdos tratassem da história nacional do país de origem. Mesmo no caso dos livros brasileiros, que trazem capítulos de História pátria conjugados com a História Geral e História da América, em uma configuração denominada de História Integrada, deu-se ênfase à análise dos conteúdos de História Geral. Decorre dessa opção um deslocamento no foco central da investigação, pois se deixam as questões da identidade nacional ou da genealogia da nação, bastante clássicas na historiografia sobre o livro didático, para se privilegiar uma temática mais ampla: a concepção de Historia expressa por esses livros. Portanto, ainda que a questão da memória continue posta, não se trata mais da memória nacional, mas de uma memória tomada como "universal" que se imagina importante preservar e que, por isso, ensina-se às novas gerações. De todo modo, continua posta a questão das identidades, mas agora numa perspectiva mais ampla.

A escola é reconhecidamente um agente fundamental no processo de socialização das novas gerações e da formação intelectual dos indivíduos, contribuindo fortemente para a preservação de certas tradições intelectuais. Mas, observa Pierre Bourdieu ${ }^{21}$, apropriar-se da "sua" cultura será sempre um processo distinto do processo de apropriação da cultura dos "outros", pois será sempre uma apropriação mediada e erudita. As aulas de História Geral certamente são momentos privilegiados dessa apropriação, em que os alunos têm oportunidade de conhecer as experiências históricas de outras sociedades. Interessa-nos saber, então, como os livros didáticos analisados fazem isso: que tipo de apropriação propiciam? Quem são os sujeitos dessa história? São semelhantes aos sujeitos da sua história pátria? Isso nos remete á questão da cultura histórica escolar.

Dominique Julia define cultura escolar como "um conjunto de normas que definem conhecimentos a ensinar e condutas a inculcar, e um conjunto de práticas

${ }^{20}$ O Institut Georg-Eckert, importante centro de pesquisa sobre os livros didáticos da Alemanha, desenvolve trabalhos comparativos, visando colaborar para que sejam eliminados dessas publicações preconceitos e estereótipos que venham a contribuir para rivalidades entre os povos. Apesar da relevância dos trabalhos publicados, o escopo deles é bem mais limitado do que o nosso propósito. Para maiores informações, ver Moniot, Henry. Eiseigner l'histoire: des manuels à la mémoire. Nancy: Peter Lang, 1983.

${ }^{21}$ Bourdieu, Pierre. A economia das trocas simbólicas. São Paulo: Perspectiva, 1992. 
que permitem a transmissão desses conhecimentos e a incorporação desses comportamentos"22. Procuraremos identificar, assim, as características dos saberes históricos apresentados nos livros, entendendo-os como parte de uma cultura escolar mais ampla, tanto no tocante aos conteúdos como com as habilidades no trabalho com tais conhecimentos, o que nos faz deter especial atenção às atividades propostas. O trabalho comparativo nos possibilitará identificar alguns traços da cultura histórica difundida nas escolas dos três países, verificando se há traços comuns entre eles.

\section{A SELEÇÃO DAS OBRAS}

Dada a envergadura da pesquisa, foi imprescindível selecionar os livros a serem analisados, uma vez que em cada país há um número grande de obras disponíveis para escolha dos professores. O critério para a seleção foi mercadológico, ou seja, optou-se pelos dois livros mais vendidos em cada um dos países. Desse modo, como são os professores que, nos três países, escolhem os livros com os quais preferem trabalhar, seria possível chegar às propostas pedagógicas que encontram um expressivo número de adeptos entre eles, o que nos faz supor que, dentre as várias opções disponíveis, essas seriam as que encontram maior receptividade e concordância dos professores.

Para chegar a essas obras, foram consultados editores mexicanos e argentinos. No caso dos livros brasileiros, como editora, tive acesso a pesquisas realizadas pela ABRELIVROS (Associação Brasileira de Editores de Livros), entidade que congrega os editores de livros didáticos de todo o país, que apontam anualmente as obras mais vendidas em cada segmento escolar e por disciplina. No ano de 2002, a liderança era ocupada por uma obra da Editora Moderna, subsidiária da editora espanhola Santillana e outra, da Editora Scipione.

É preciso sublinhar uma particularidade do caso mexicano: segundo todos os editores consultados, boa parcela dos professores não adota um livro didático único, preferindo o que eles chamaram de "antologia pessoal", ou seja, um conjunto de textos, em sua maior parte xerocopiados, que servem de apoio para o seu trabalho em classe. Aqueles que optam por um livro - número esse que vem

22 Julia, Dominique. "A cultura escolar como objeto histórico". Revista Brasileira de História da Educação, no. 1, p. $9-43,2001$. 
crescendo, segundo os entrevistados -, preferem majoritariamente a obra publicada pela Editora Santillana. O domínio é tão amplo, que o segundo mais vendido não foi identificado com clareza por nenhum dos entrevistados (na falta de pesquisas semelhante à realizada no Brasil), dada a pequena vendagem. Entretanto, no ano em que fizemos a coleta dos livros, acabara de ser publicado, pela Editora Oxford, uma obra escrita por uma equipe de professores das Escolas Nacionais Preparatórias, cuja aceitação tinha sido muito boa nos dois cursos oferecidos pela Universidade Nacional do México, segundo o coordenador de História daquela instituição. Como uma parcela importante dos estudantes do Ensino Médio os freqüentam, optou-se por esse livro como segunda amostragem $^{23}$. Já no caso argentino, houve consenso entre os entrevistados em apontar os livros da Editora Santillana e da Puerto de Palos como os líderes de mercado, cabendo ao livro da primeira a maior vedagem.

Assim, são os seguintes os livros que serviram de base para o trabalho, tomados portanto como nossas fontes de investigação:

- Obras brasileiras:

História: das Cavernas ao Terceiro Milênio. Myriam Becho Mota e Patrícia Ramos Braick Editora Moderna, $2^{a}$ edição, 2002.

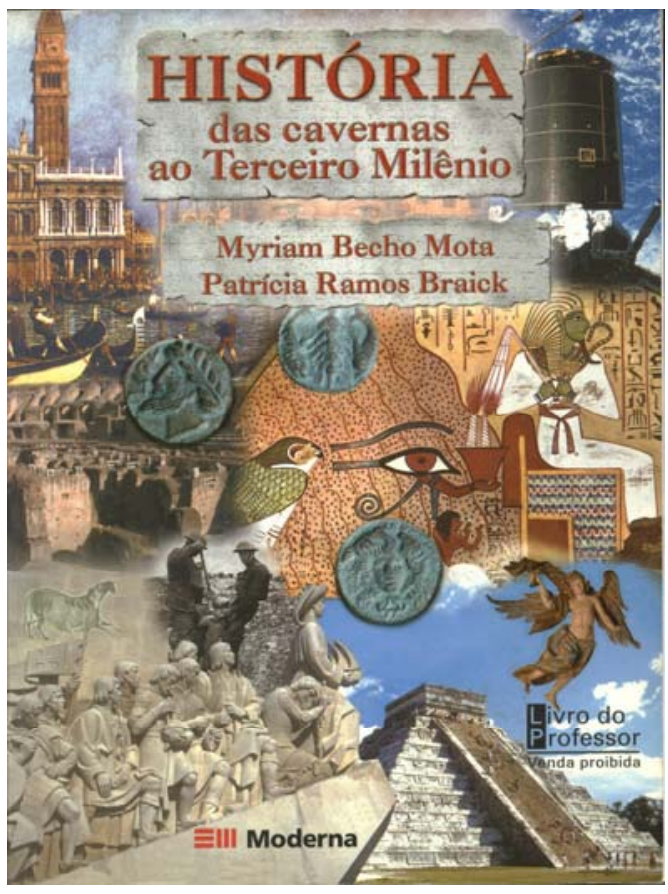

${ }^{23}$ Soubemos, pelo mesmo coordenador, que muitos professores das Escolas Nacionais Preparatórias e dos Centros de Ciências Humanas, duas modalidades de Ensino Médio oferecidas pela UNAM, faziam uso de um conjunto de apostilas com os conteúdos básicos do programa oficial. Ainda que eu tenha me empenhado, não tive acesso a esse material, que poderia servir como um interessante contraponto de análise. 
História para o Ensino Médio: história geral e do Brasil.

Série Parâmetros

Cláudio Vicentino e Gianpaolo Dorigo

Editora Scipione, $1^{\mathrm{a}}$ edição, 2001.

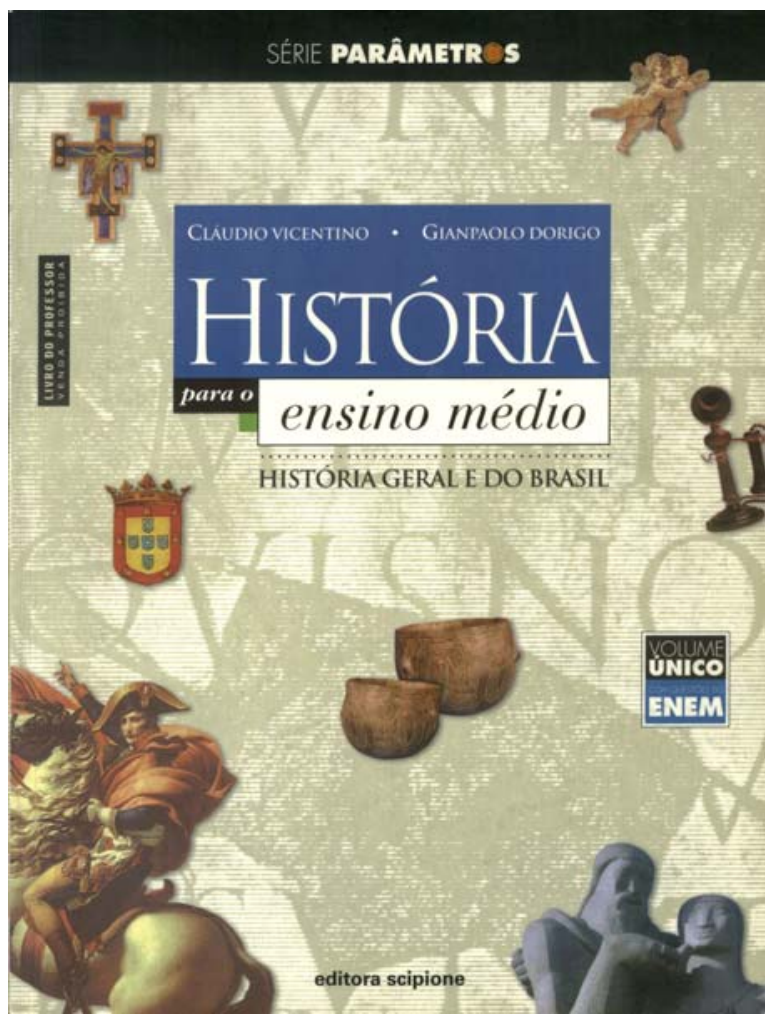

- Obras argentinas:

Historia del mundo contemporáneo

Desde la "doble revolución" hasta nuestros dias

Coleção Polimodal

Luciano de Privitellio, Lucas J Luchilo, Silvina I. Montenegro, Liliana Cattáneo

e Alejandro Cattaruzza

Editora Santillana, $1^{\mathrm{a}}$ edição, $4^{\mathrm{a}}$ reimpressão, 2002

HISTORIA

del mundo contemporáneo

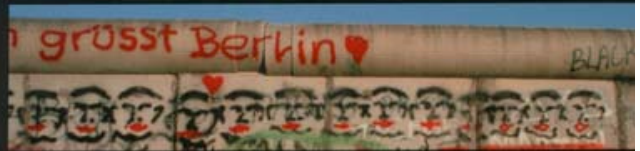

Desde la "doble revolución"

hasta nuestros dias

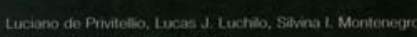

Illana Cattaneo, Alesandro Cattaruza 


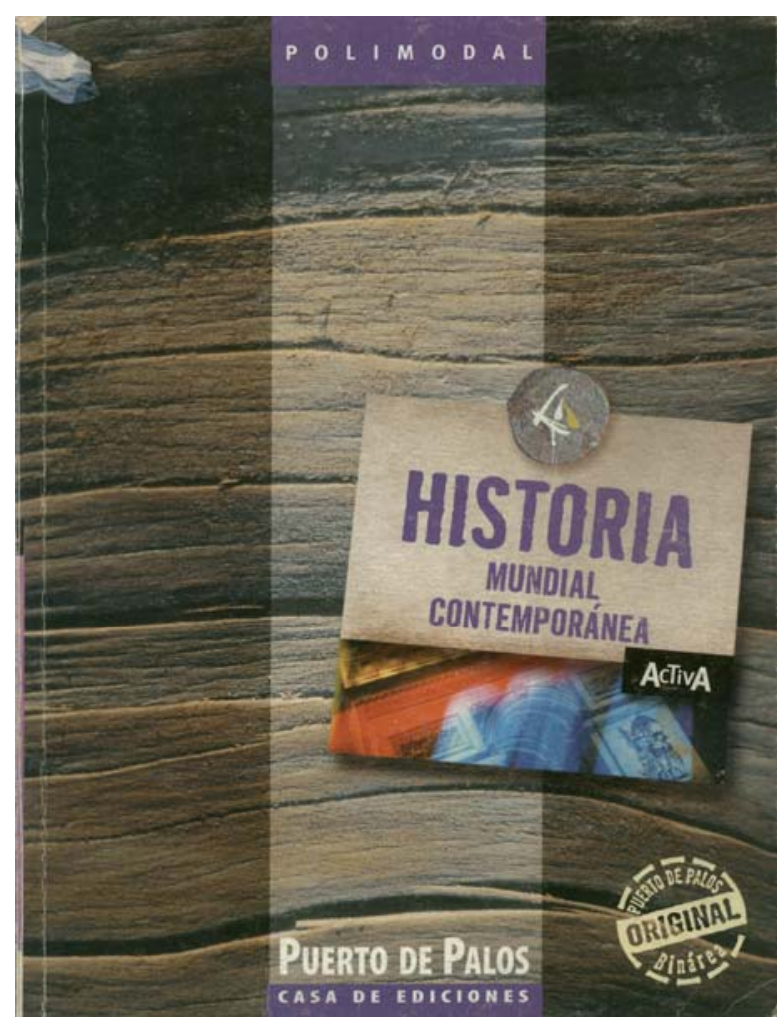

- Obras mexicanas:

Historia Universal

Bachillerato

Marialba Pastor

Editorial Santillana, $2^{a}$ edição, $4^{a}$ reimpressão, 2003.
Historia Mundial Contemporânea

Serie Activa

Marisa Alonso, José Benclowicz, Karin Grammático, Melina Piglia, Valeria Pita, Marta Poggi, Claudia Touris e Silvia Valle Puerto de Palos Casa de Ediciones, $1^{\mathrm{a}}$ edição, 2002.

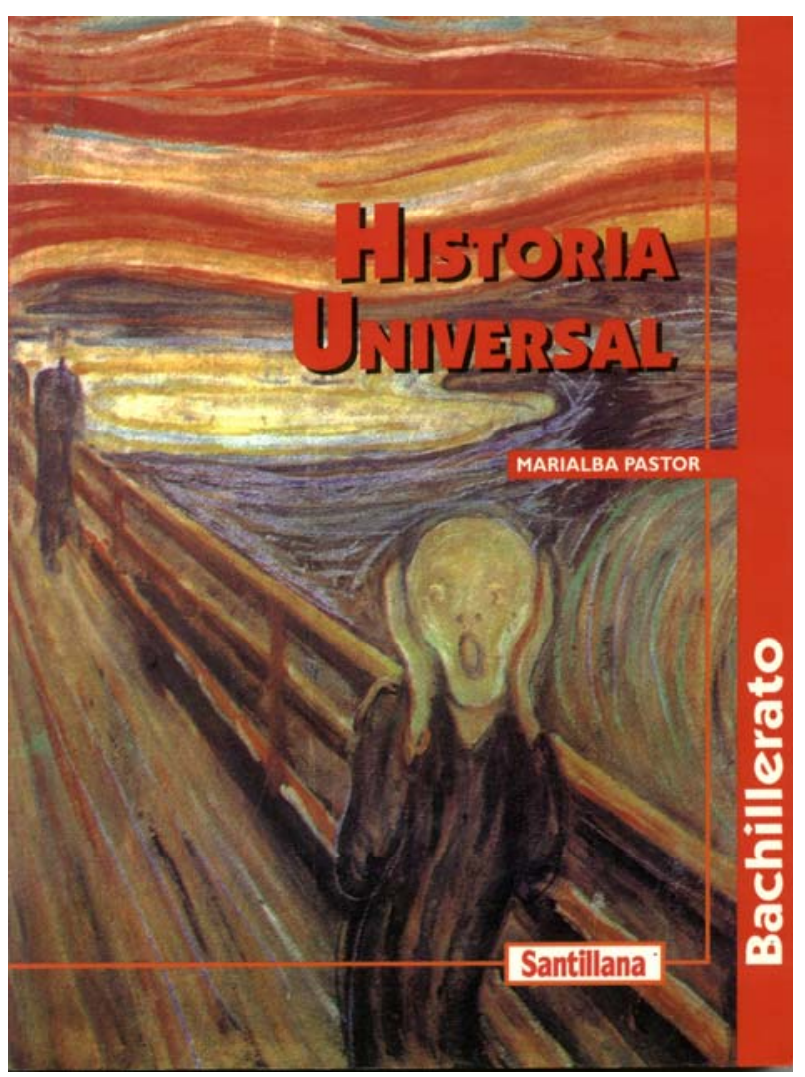


Historia Universal : De los orígenes de la modernidad a la crisis del mundo globalizado

Atzin Julieta Pérez Monroy, Geraldo Lara Cisneros e Juan Manuel Pomero Garcia

Oxford University Press Mexico, $1^{\mathrm{a}}$ edição, 2003

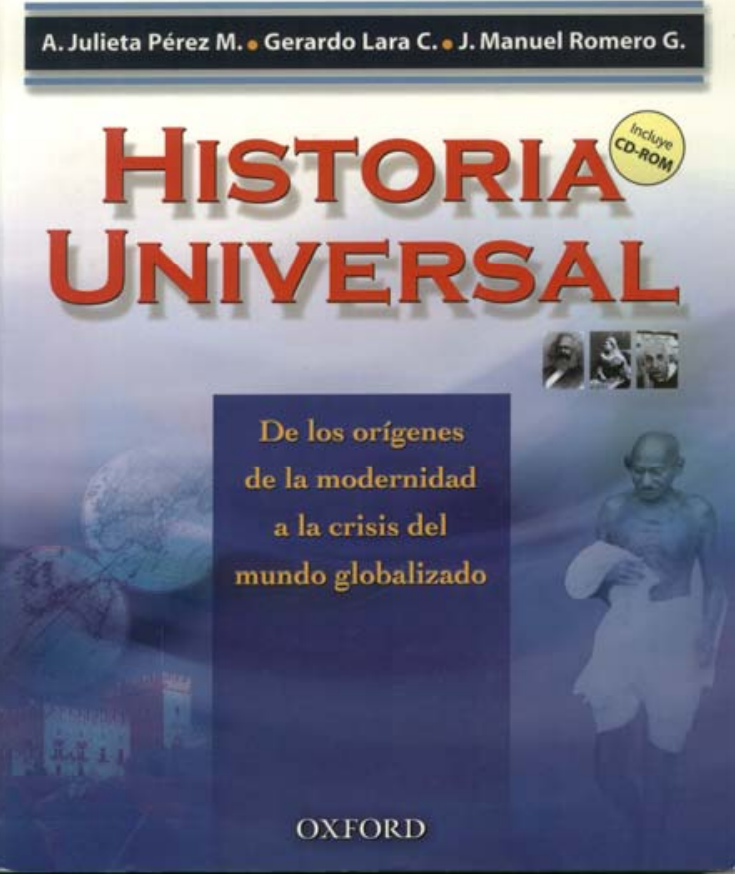

\section{A ESTRUTURA DO TRABALHO}

Esta tese é constituída por seis capítulos e uma conclusão. No primeiro capítulo, procuramos apresentar um quadro bastante abrangente do sistema educacional mexicano, argentino e brasileiro, de modo a compreendermos em que situação de escolaridade um jovem chega ao Ensino Médio em cada um dos países. Na medida do possível, procuramos caracterizar o perfil dos professores e dos alunos dessa etapa, além de identificar os grandes problemas enfrentados na atualidade para ampliar a parcela de estudantes que conseguem finalizá-la.

A abordagem comparativa passa a ser adotada mais efetivamente a partir do capítulo II, quando apresentamos os referenciais curriculares que orientam o ensino de História nos três países. Esses referenciais, por sua vez, inserem-se em um quadro mais amplo, em que grandes diretrizes educacionais foram discutidas em alguns fóruns mundiais, diretrizes essas adotadas pela comunidade de nações em desenvolvimento. Nesses debates, as idéias de alguns autores ganharam expressão mundial, o que ajuda entender porque alguns paradigmas comuns são encontrados nos projetos educacionais dos três países. Registre-se que alguns organismos internacionais têm desempenhado papel decisivo para a 
implementação dessas políticas, como a UNESCO e o Banco Mundial. Esse último, por exemplo, oferece financiamentos para projetos de grande envergadura, como por exemplo aquele que distribui livros didáticos para estudantes brasileiros do nível fundamental. Os dois primeiros capítulos, portanto, fornecem a moldura que enquadra o nosso estudo. Nosso intuito foi fazer com que, por meio deles, se possa compreender em que contexto educacional transcorre o ensino de História no nível Médio nos três países, tanto do ponto de vista das estruturas educacionais como das questões curriculares recentemente enfrentadas.

No capítulo III os livros didáticos tornam-se nossa questão central. Após tecer algumas considerações sobre os estudos em torno dos livros didáticos, tanto no plano mundial como nos três países em tela, e identificar os fundamentos que sustentam nossa pesquisa nesse campo, iniciamos a analise das obras selecionadas, começando pela sua materialidade. Depois, procuramos ver quais são as concepções de História que os livros explicitam nas páginas de apresentação ou nos capítulos de introdução, quando, em geral, os autores apresentam os fundamentos dessa disciplina.

Uma incursão mais profunda nos conteúdos trabalhados em cada um dos volumes é realizada no capítulo seguinte, quando identificamos uma série de semelhanças e diferenças nas abordagens das obras, reveladoras de como os autores concebem a História. Especial atenção demos à questão dos sujeitos históricos, o que nos possibilitou, no capítulo 5, fazer um recorte específico sobre as visões de América Latina expressas nos livros, demonstrando, entre outros aspectos, como o problema do estudo da História latino-americana é muito mais sério do que a mera inclusão de conteúdos nos programas curriculares. Por meio de nossa analise nesses dois capítulos, procuramos realçar o imbricamento entre as concepções de História e do seu ensino, revelando como elas constituem de fato uma unidade.

No último capítulo, o objetivo continua sendo o mesmo, mas agora invertendo o foco de observação, passando a privilegiar as questões relacionadas à aprendizagem, o que nos leva a analisar mais detidamente as atividades propostas ao longo dos volumes. 
Ao final, retomando as questões curriculares e sobre o ensino de História, podemos verificar como, apesar de importantes traços comuns, como no tocante às diretrizes educacionais e ao eixo central organizador dos conteúdos da disciplina no Ensino Médio, verificam-se grandes diferenças no ensino de História nesses três países, cabendo aos livros didáticos um papel relevante nessa configuração. Desse modo, esse estudo demonstra como a afirmativa de Robert Darton também tem grande validade quando se pensa os livros didáticos. 


\title{
Capítulo I
}

\section{ESTRUTURAS EDUCACIONAIS E POLÍTICAS PÚBLICAS PARA O ENSINO MÉDIO}

\begin{abstract}
[...] América latina se está transformando en un verdadero laboratorio de reflexión acerca de la educación secundaria y su destino, que puede derivar en su progresiva desaparición como espacio formativo creado para dar respuesta a la sociedad industrial moderna de fines del siglo XIX europeo y adecuado para sus transiciones de la primera mitad del siglo XX. Esa educación secundaria fue adoptada

por una América latina que siempre miró hacia Europa y ocasionalmente hacia los Estados Unidos para diseñar sus proprias formas educativas, y que ahora requiere combinar de modo diferente la mirada hacia afuera con la reflexión sobre si misma.
\end{abstract}

Cecilia Braslavsky

Nesse capítulo apresentamos, em linhas gerais, as estruturas educacionais do Brasil, da Argentina e do México, destacando os dispositivos constitucionais e infraconstitucionais, a partir dos quais se organiza o sistema educacional nos três países. Desse modo, identificamos as etapas de escolarização obrigatória e não obrigatória, bem como localizamos, na trajetória regular dos estudantes, o momento em que se cursa o Ensino Médio, etapa sobre a qual nosso estudo se detém. Trataremos das políticas públicas de ampliação do atendimento escolar, visando a universalização da educação básica, seguidas nos últimos anos pelos governos brasileiro, mexicano e argentino. Apresentamos, ainda, um perfil sumário do público atendido nesse nível escolar e dados de censos oficiais dos três países. Caracterizamos, o quanto possível, o perfil dos professores que lecionam no ensino médio no Brasil, Argentina e México, procurando identificar sua formação profissional, as condições de trabalho e algumas dificuldades que enfrentam em seu dia-a-dia. 
Com intuito de facilitar a exposição e a compreensão dessas estruturas, o capítulo apresenta a realidade de cada país separadamente. Ao final dele destacamos algumas semelhanças que chamam a atenção, assim como as singularidades verificadas em cada um deles.

\section{BRASIL}

\subsection{A legislação educacional}

A Constituição de 1988 estabelece que a educação é um dos direitos sociais de que gozam todos o brasileiros ${ }^{24}$. No seu capítulo III, fica posto que a educação é um direito de todos e um dever do Estado e da família, devendo ser incentivada e promovida por toda a sociedade. Seus objetivos são o pleno desenvolvimento da pessoa, seu preparo para o exercício da cidadania e sua qualificação para o trabalho. Dentre os princípios que devem orientar a educação está a "igualdade de condições para o acesso e permanência na escola" ${ }^{25}$. Apenas o Ensino Fundamental é obrigatório, mas o Inciso II do Art. 208 prevê a progressiva extensão da obrigatoriedade e gratuidade ao ensino médio ${ }^{26}$. Quanto ao financiamento da educação pública, determina a Constituição que os estados e o Distrito Federal devem empregar $25 \%$ de seu orçamento em educação, sendo 15\% obrigatoriamente no Ensino Fundamental e outros 10\% prioritariamente no Ensino Médio. A União deve aplicar nunca menos de $18 \%$ de todas as receitas provenientes de impostos nesse mesmo âmbito, sendo parte dele em ações de apoio ao Ensino Médio.

Dentre os dispositivos educacionais infraconstitucionais, o mais importante é a Lei 9394/96, a Lei de Diretrizes e Bases (LDB), aprovada em dezembro de 1996. Dentre as muitas determinações que estabelece, devemos destacar as que tratam da organização da estrutura educacional. Há dois níveis de educação no país: a Educação Básica e a Superior. A primeira compreende 3 segmentos: Educação Infantil, que atende as crianças entre 0 e 6 anos; a Educação Fundamental, que atente as crianças e jovens entre 7 e 14 anos, compreendendo

${ }^{24}$ Constituição da República Federativa do Brasil, Capítulo II: Dos Direitos Sociais.

25 Inciso I do Artigo 206 do Capítulo III.

${ }^{26}$ No Artigo $214 \mathrm{~m}$ que trata do Plano Nacional de Educação, fica estabelecida que uma das suas metas deve ser a universalização do atendimento escolar. 
8 séries $^{27}$ de estudo, com um ano de duração cada um, e a Educação Média, que atende alunos entre 15 e 17 anos, em cursos com duração mínima de 3 anos. No final de 2005, o Ensino Fundamental passou ter a duração de nove anos, uma vez que a lei 11.274 instituiu o último ano da Educação Infantil (a ser cursada aos 6 anos) como obrigatório. Assim, a Educação Básica passou a ser composta de 12 anos de escolaridade, sendo os nove anos do Ensino Fundamental obrigatórios. Já o Ensino Superior está organizado em graduação e pós-graduação, ambas com períodos de duração bastante variados, dependendo do curso a ser seguido.

O Artigo 35 define as finalidades do Ensino Médio, entendido como etapa final da educação Básica:

I. a consolidação e o aprofundamento dos conhecimentos adquiridos no ensino fundamental, possibilitando o prosseguimento de estudos;

II. a preparação básica para o trabalho e a cidadania do educando, para continuar aprendendo, de modo a ser capaz de se adaptar com flexibilidade a novas condições de ocupação ou aperfeiçoamento posteriores;

III. o aprimoramento do educando como pessoa humana, incluindo a formação ética e o desenvolvimento da autonomia intelectual e do pensamento crítico;

IV. a compreensão dos fundamentos científico-tecnológicos dos processos produtivos, relacionando a teoria com a prática, no ensino de cada disciplina". No artigo seguinte, que trata do currículo desse nível escolar, fica estabelecido que a diretriz que deve reger a sua elaboração, entre outros aspectos, deve destacar o "processo histórico de transformação da sociedade e da cultura."

${ }^{27}$ A LDB faculta a organização do Ensino Fundamental em ciclos, com duração de dois anos, podendo a promoção ou retenção dar-se depois desse intervalo de tempo. As oito séries (ou 4 ciclos) estão organizados em duas etapas (ainda nomeadas informalmente de primário e ginásio), em que a organização escolar se dá em bases bastante distintas: enquanto nas quatro primeiras séries predominam as classes regidas por um único professor polivalente, eventualmente com auxílio de professores específicos para certas áreas e atividades, como educação física, nas quatro séries finais as aulas são ministradas por vários professores, encarregados de disciplinas específicas. A organização dos programas e do horário escolar, nesse sentido, aproxima o chamado Ensino Fundamental maior da estrutura do Ensino Médio. 
Ainda que o Ensino Médio possa ser cursado com alguma modalidade de educação profissional, a atual LDB define para esse nível de ensino um caráter de formação integral do aluno.

\section{2. Perfil dos alunos}

Historicamente, o Ensino Médio, desde quando constituía uma etapa da Educação Secundária ${ }^{28}$, sempre foi reservado a uma pequena parcela da sociedade. Seu objetivo básico era servir de etapa preparatória para os estudos superiores, razão pela qual os estudos sobre esse nível escolar sempre ressaltaram a falta de uma identidade própria dentro do sistema educacional. Ainda hoje esse problema persiste, sendo muito freqüentes os debates sobre a finalidade dos cursos médios: formação integral dos estudantes ou preparação mais específica para o mercado de trabalho? Ou seja, o mais apropriado seria oferecer aos alunos uma formação geral, preparatória para a vida adulta e para seguir os cursos superiores ou, ao contrário, deveria-se habilitá-los para o ingresso no mercado de trabalho? No próximo capítulo teremos oportunidade de nos determos nessa questão, que tem peso decisivo na composição curricular e da qual decorre um debate comum aos três países.

Enquanto atendeu a um conjunto reduzido de alunos, em geral moradores de cidades de grande e médio porte - no que se entendia por isso ao longo dos três primeiros quartéis do século XX em nosso país - os problemas enfrentados diziam respeito basicamente aos âmbitos do currículo (composição da grade curricular e da carga horária), formação de professores (em quantidade e com a capacitação adequadas) e processos institucionais de avaliação ${ }^{29}$. No entanto, a partir dos anos 1970, e com maior ênfase a partir dos anos 1990, começou a haver uma maior pressão dos segmentos médios e populares da população para que seus filhos tivessem acesso a esse nível escolar. Fruto de um complexo processo econômico e

${ }^{28}$ O Ensino Secundário foi instituído formalmente apenas em 1931, pela Reforma Francisco Campos. Entre 1942 e a Reforma promovida pela lei 5692/71, o Ensino Secundário compreendia duas etapas escolares: o ginásio e o curso colegial, que tinha duas modalidades: clássico e científico. A partir desse ano, o curso ginasial passou a integrar o Ensino de $1^{\circ}$. Grau, composto de oito séries, seguido pelo curso de $2^{\circ}$. grau, cuja duração podia ser de três ou quatro anos.

29 Sobre essas questões, ver, entre outros, Hollanda, Guy. Programas e Compêndios de História para o Ensino Secundário Brasileiro 1931- 1956. Rio de Janeiro: INEP - Ministério da Educação e Cultura, 1957 e Leite, Miriam Moreira. O Ensino da História no Primário e no Ginásio. São Paulo: Cultrix, 1969. 
social, cuja expressão mais visível era o acelerado crescimento dos centros urbanos, essas pressões começaram a forçar os governos estaduais, responsáveis pelo atendimento desse nível, a ampliar a rede de escolas, obrigando, inclusive, a construção de unidades em municípios que não dispunham de classes para esse nível escolar. Assim, entre 1970 e 2000 assistiu-se a um expressivo crescimento do ensino secundário ou médio no Brasil. Em 1970, havia 1.003.475 alunos matriculados nos cursos colegiais, nomenclatura do então Ensino Médio, número que passou para 3.770.182 em 1991. Entre 1994 e 1999, houve um crescimento de 57,3\% no número de matrículas, o que representa uma média de 11,5\% ao ano, fazendo chegar, nesse último ano, a cerca de 7,7 milhões de alunos matriculados ${ }^{30}$.

Nos últimos cinco anos, essa demanda tem crescido ainda mais. Dois fatores explicam esse fenômeno: primeiro, o fato de que muitos jovens não encontram espaço no mercado de trabalho, que exige cada vez mais a conclusão do ensino médio como condição básica para ingresso nesse mercado; segundo, uma política de aceleração escolar que tem proporcionado um aumento no número de alunos concluintes do Ensino Fundamental, que, assim, passam a requerer uma vaga na etapa escolar subseqüente.

O resultado prático dessa pressão para ampliação da rede escolar é que as escolas de Ensino Médio passaram a receber alunos pertencentes a famílias que até então não tinham chegado até esse estágio de escolaridade ${ }^{31}$, e cujo capital cultural é bastante diferente daquele que caracterizava os antigos alunos. As expectativas desses estudantes com relação à escola tende a ser igualmente distinta ${ }^{32}$.

${ }^{30}$ Cf. Berger Fo. Ruy Leite. "Enseñanza media: los desafios de la inclusión" . In Braslavsky, Cecilia. La educación secundaria.¿Cambio o inmutabilidade? Buenos Aires: Santillana, 2001, p.338/339. Dados do MEC/INEP/SEEC informam ainda que em 1980 o total de matriculados era de 2.819.182 e que em 2000 chegou-se a 8.192.948 matriculados.

${ }^{31}$ Enquanto aproximadamente $20 \%$ dos pais de alunos da escola privada cursaram o nível superior, apenas $15 \%$ dos pais dos alunos da rede pública passaram pelo ensino fundamental. Cf. Abramovay, Miriam e Castro, Mary. Ensino Médio: múltiplas vozes. Brasília: UNESCO/NEC, 2003, p. 147.

${ }^{32} \mathrm{Na}$ verdade, as mudanças sociais e culturais das últimas décadas também provocaram um esgotamento de um certo modelo escolar, ainda muito centrado na exposição de conteúdos por parte dos professores, fazendo com que os jovens perdessem o interesse pelo ambiente escolar, exceto, talvez, na sua dimensão de sociabilidade. A medida que a escola perdeu a condição de grande janela para o mundo e para o conhecimento, ou de porta para o mercado de trabalho, o seu valor social para os jovens esvaiu-se. Sobre o tema, ver entre outros, Bueno, Maria Sylvia S. Políticas atuais pra o Ensino Médio. Campinas, Papirus, 2000; Zibas, D., Aguiar, M. e Bueno, Maria Sylvia. O Ensino Médio e a Reforma da Educação Básica. Brasília: Plano, 2002. 
O sistema ainda enfrenta enormes desafios: é muito elevada a defasagem entre a idade e a série escolar cursada. Assim, apenas 32,6\% dos alunos matriculados em 1999 tinham a idade prevista, entre 15 e 17 anos. Além disso, dos quase 44 milhões de estudantes integrantes do sistema escolar brasileiro naquele mesmo ano, cerca de 37 milhões de fato deveriam dele participar, por contarem entre 7 e 17 anos. Em média, os alunos brasileiros levam 11 anos para cursar os oito anos do Ensino Fundamental ${ }^{33}$.

Uma pesquisa realizada pela UNESCO durante o ano de 2002 fornece informações sobre esse mesmo problema, com a vantagem de detalhar a situação própria a diversos estados. Foi constatado que a idade média dos alunos que freqüentavam o Ensino Médio em treze capitais era de 19 anos. Ainda que em certas capitais houvesse um predomínio de alunos entre 16 e 17 anos, como em São Paulo e Curitiba, em outros - como Belém, Teresina e Maceió - mais de 30\% dos alunos contam mais de 20 anos, especialmente nos cursos noturnos. Esses dados nos levam a pensar que essa escolaridade cheia de percalços, geralmente associada a um ingresso precoce no mercado de trabalho, faz com que os alunos brasileiros que cursam o Ensino Médio possuam concepções de mundo e de história marcadas pelas duras condições de vida que enfrentam. Essas concepções por certo que interferem diretamente no sentido que atribuem à História ensinada na escola. Por outro lado, essa situação nos lança a questão de verificar se os livros didáticos pressupõem leitores com esse tipo de vivência.

A distorção na relação idade/série não é mais problemática do que a incidência daqueles que abandonam os estudos sem concluí-los. Enquanto entre 1970 e 1973 74\% dos que ingressavam no Ensino Médio concluíam seus estudos, no período 1977-1980 esse índice caiu para 51\% e entre 1991-1994 reduziu-se a 44\%; portanto, se por um lado houve ampliação no atendimento, por outro, menos de metade dos que ingressam na $1^{a}$ série do Ensino Médio chegam ao final do terceiro ano. Mais uma vez o fato de expressiva parcela dos alunos freqüentarem cursos noturnos ajuda a explicar esses resultados ${ }^{34}$.

33 Berger Fo. Op. Cit., p. 343.

34 Idem, p.339. O mesmo autor informa que, entre outros motivos, esse elevado número de alunos em cursos noturnos se explica porque o sistema cresceu de modo desordenado e, muitas vezes, as vagas oferecidas aproveitavam as salas usadas durante o dia para os cursos do Ensino Fundamental. De onde se conclui que é comum uma escola atender a alunos de todas as etapas escolares ao longo de um dia, não oferecendo, portanto, espaços apropriados para cada uma delas. 
Outro aspecto que chama atenção é que enquanto em 1980 55,8\%dos matriculados freqüentavam escolas particulares, em 1990 esse percentual reduziu-se para 38,4\% e em 1998 chegou a apenas 20,5\%, indicando um expressivo alargamento do atendimento das escolas públicas (federais, estaduais e municipais) na última década.

\subsection{O Perfil dos professores}

Segundo o então Secretário de Educação Média e Tecnológica do Ministério da Educação, Ruy Berger Filho, 88\% dos professores que lecionavam no Ensino Médio em 1999 tinham formação superior completa, o que significava que aproximadamente 45 mil docentes não tinham ainda graduação concluída ou mesmo contavam apenas com o Ensino Médio ${ }^{35}$. Esse é outro sério entrave para a expansão da rede escolar, uma vez que para muitas disciplinas já não há professores com formação apropriada, quanto mais para atender maior número de escolas. É bom lembrar que no Brasil o exercício do magistério requer um curso de licenciatura, o que faz com que um bacharel em Biologia ou Química, por exemplo, só possa dar aulas, legalmente, depois de cursar uma série de disciplinas ligadas ao ensino. Como a remuneração dos professores é, quase sempre, inferior a recebida por aqueles que seguem um outro ramo profissional, poucos optam pela carreira ou se orientam para os cursos de licenciatura.

Outro sério problema, decorrente do mencionado acima, é que uma expressiva parcela dos professores necessitam dar um elevado número de aulas semanais para reunir recursos suficientes para o seu sustento e o de sua família. A longa jornada de trabalho raramente é completada apenas em uma escola, o que os obrigam a deslocamentos de uma unidade a outra - não raro, uma distante da outra, muitas vezes no mesmo dia. São por demais conhecidos os reflexos das condições de vida e de trabalho no desempenho de qualquer área profissional, em particular do magistério.

35 No outro extremo, tem crescido o número de professores com curso de pós-graduação. Em Curitiba, por exemplo, 39\% atingiu esse nível de ensino, número que em Porto Alegre chega a 24,5\%. Cf. Abramovay, Miriam e Castro, Mary. Op. cit., p. 133. 
A já mencionada pesquisa Ensino Médio: múltiplas vozes, depois de entrevistar cerca de 7 mil professores de 13 capitais no ano de 2002, concluiu que é marcante a predominância de mulheres entre os professores, tanto na rede pública como privada, ainda que nessas eles estejam mais representados do que naquelas. No universo pesquisado, a maioria encontrava-se na faixa etária entre 30 e 49 anos (aproximadamente 60\%), embora fosse expressivo também o número daqueles que diziam contar até 29 anos (cerca de um terço deles), o que permite concluir que os professores, em sua maioria, são relativamente jovens, mas com considerável experiência profissional. Levando-se em conta que um professor deve começar sua carreira em torno de 23 anos, e que será preciso contar 25 (no caso das mulheres) ou 30 anos (no caso dos homens) para aposentar-se, é relativamente pequena a parcela daqueles que podem se considerar em final de carreira ${ }^{36}$.

Nesse mesmo estudo encontramos, ainda, alguns indicadores interessantes sobre o perfil sócio-econômico dos professores e seus hábitos culturais. Entre os entrevistados que lecionavam na rede pública, uma parcela que varia entre 25,7 (Belém) e 9,6 (Rio de Janeiro) disse não ter ido ao cinema nenhuma vez no ano de 2001. Por outro lado, os que diziam ter ido mais de 6 vezes aos cinema naquele mesmo ano variava entre 48\% ( Rio de Janeiro) e 28, 4 \% ( Teresina). A ida a teatros e a museus era menos freqüente do que ao cinema, com cerca de um terço dos professores entrevistados afirmando não ter ido a nenhum teatro ou museu ao longo de 2001. Quase todos os professores dispunham de TV a cores em casa e cerca de 90\% dispunham de aparelhos de CDs. Já computadores pessoais (residenciais), os números variaram entre 91,4\% em São Paulo e 57,9\% em Rio Branco, revelando as fortes disparidades regionais quando se trata da chamada inclusão digital.

É também muito discrepante a situação, por estado da federação, do percentual de professores que ingressaram na rede pública por meio de concursos. Se em Belém, 63,1\% disseram não ter ingressado por meio de um

${ }^{36}$ Dentre os estados pesquisados, chama atenção o Rio de Janeiro, onde $24 \%$ dos professores entrevistados, e pertencentes à rede pública, contavam mais de 50 anos. Em São Paulo, esse índice era de 17,4 e em Curitiba 18,3. A média de tempo de serviço dos professores no Ensino Médio oscila entre 9,2 ( Teresina) e 15,6 ( Porto Alegre). Abramovay, Miriam e Castro, Mary.Op. cit, p. 108/109. 
deles, em Belo Horizonte esse percentual chegou a 74,4\%; por outro lado, em Macapá e no Rio de Janeiro verificou-se o inverso: 85,6\% e 87,2, respectivamente, ingressaram por meio de concurso ${ }^{37}$.

Outro dado importante que o estudo da UNESCO revelou diz respeito à situação funcional. Em 11 das 13 capitais pesquisadas, o percentual de professores efetivos é superior ao percentual de professores em outras situações funcionais (permanente, contrato temporário ou precário de trabalho, substituto eventual). As exceções são Belo Horizonte e Rio Branco. Belo Horizonte é a única capital pesquisada na qual o percentual de professores efetivos nas escolas públicas $(25,3 \%)$ é inferior ao percentual de professores que possuem contrato precário ou temporário $(69,4 \%)$. Nas escolas privadas de Cuibá, o percentual de professores efetivos $(36,7 \%)$ é inferior à porcentagem dos que são permanentes (39,6\%). Em Teresina, embora o percentual de professores efetivos em escolas privadas seja alto $(48,7)$, não é superior à soma das outras alternativas.

Entre as escolas pesquisadas, a segunda situação funcional mais comum é a dos professores que possuem contrato precário ou temporário de trabalho. Apenas em Belos Horizonte e Macapá constituem exceção. Em Belo Horizonte, como já vimos, o percentual de professores da escola pública que possuem contrato precário ou temporário é superior ao percentual de professores efetivos. Em Macapá, o percentual de professores permanentes $(18,2 \%)$ é superior ao percentual dos professores que possuem contrato precário ou temporário $(9,2 \%)$. Nas escolas privadas pesquisadas, o segundo tipo de situação funcional mais comum é a dos professores que possuem contrato permanente. As exceções são Cuiabá e Teresina ${ }^{38}$.

Apesar desses problemas, quando analisamos os dados em termos nacionais, verificamos que mais de $75 \%$ dos professores ingressaram na carreira docente por meio de concurso público, o que seria indicador de uma relativa estabilidade funcional desses profissionais.

Quanto à renda, a maioria dos professores pesquisados se declararam insatisfeitos com a renda obtida com seu trabalho. Parcela expressiva se disse 
públicas, mas a reação também foi freqüente nas escolas privadas. Menos de $5 \%$ se consideram satisfeitos com seus rendimentos.

\section{4. Políticas públicas de universalização}

Com cerca de $97 \%$ das crianças entre 7 e 14 anos matriculadas no Ensino Fundamental, o governo brasileiro hoje se esforça para ampliar o atendimento aos jovens que querem cursar o Ensino Médio. Não há um movimento mais consistente no sentido de assegurar constitucionalmente a obrigatoriedade a esse nível escolar, uma vez que os aportes financeiros para tanto seriam bastante grandes e nem todos os governos estaduais suportariam a inclusão desses investimentos em seus orçamentos.

Ainda assim, nos últimos anos, o governo federal tem procurado aumentar os recursos repassados para os estados e destinados ao nível Médio ${ }^{40}$. Com apontamos mais acima, a LDB, em seu inciso II, artigo $4^{\circ}$., determina que é dever do Estado "promover a progressiva extensão da obrigatoriedade do Ensino Médio". As avaliações comparativas com outros países em desenvolvimento têm realçado a necessidade de o país melhorar seus indicadores educacionais, ampliando a escolaridade média dos brasileiros. Mais do que interesses sociais, visando diminuir as gritantes desigualdades que marcam a sociedade brasileira, são interesses econômicos que têm pressionado nessa direção. Embora o custo da mão de obra e a disponibilidade de recursos naturais e matérias primas continuem sendo fatores importantes, atualmente o fator que parece ser determinante para a atração de investimentos estrangeiros é a relação entre salários e qualificação da mão de obra. A revolução tecnológica das últimas duas décadas tornou os processos produtivos e mesmo a prestação de serviço menos dependentes de mão-de-obra intensiva. Desse modo, a escolaridade média da

40 O "Projeto Escola Nova" é uma das iniciativas com esse objetivo. O governo federal apóia projetos desenvolvidos nas unidades da federação, garantindo aportes de recursos mediante contrapartidas dos estados. Parte dos recursos aplicados vêm de organismos internacionais, como o Banco Interamericano de Desenvolvimento (BID). Outra iniciativa nesse sentido é a transformação do FUNDEF em FUNDEB, mas que até outubro de 2006 ainda não tinha sido aprovada pelo Congresso. Desse modo, esse fundo federal passaria a atender a toda educação básica, favorecendo a ampliação do atendimento no ensino médio. 
população passou a ser um dos aspectos importantes a ser considerado pelos investidores internacionais, o que tem obrigado tanto o governo federal como os estaduais a ampliar suas ações no sentido de aumentar o número de jovens atendidos pelo Ensino Médio. Nesse sentido, um dos compromissos assumidos no Plano Nacional de Educação (Lei 10127/2001) é que até 2011 o Brasil atinja $100 \%$ de atendimento dos jovens entre 15 e 17 anos $^{41}$. Por outro lado, uma análise de caráter econométrico dos resultados educacionais indica que ainda é relativamente baixa a relação custo/benefício dos investimentos feitos nos últimos anos, uma vez que o sistema ainda não foi capaz de reter os alunos tanto no Ensino Fundamental como, principalmente, no Ensino Médio, conforme apontado anteriormente. A evasão representa, deste ponto de vista, um duplo prejuízo, uma vez que os alunos representam investimento não aproveitado integralmente (não chegam a obter um certificado de conclusão escolar) e impedem o aumento do tempo médio de escolaridade da população ${ }^{42}$.

Tomando-se dados estatísticos de 2001, para uma população total de mais de 169 milhões e brasileiros, os jovens com idade entre 15 e 17 anos somavam 10,3 milhões. Desses, 4 milhões freqüentavam o Ensino Médio e 1 milhão ainda não haviam concluído o Ensino Fundamental ou estavam integrando algum programa de Educação de Jovens e Adultos (EJA). De onde se conclui que mais de 5 milhões de jovens dessa faixa etária estavam fora da escola. Não há porque pensar que esse quadro tenha se alterado substancialmente nos anos mais recentes.

${ }^{41}$ O PNE previa que em 2 anos, a partir do início da sua vigência, todos os egressos do Ensino Fundamental deveriam encontrar uma vaga no Ensino Médio, fato que parece assegurado quando se considera apenas o universo de alunos que, assim que concluem o Ensino Fundamental, dão continuidade a seus estudos. Contudo, é elevada a parcela daqueles que interrompem, ainda que temporariamente, seus estudos ao término do Fundamental. Cf. Plano Nacional de Educação. Documento disponível em www.mec.gov.br./consed.

42 Dessa questão decorre outro sério problema, relativo à aprovação/retenção dos alunos. Pressionado a apresentar resultados mais positivos, é dominante a opinião em todo o sistema escolar brasileiro de que a promoção dos alunos não depende de mérito ou aprendizagem efetiva; a aprovação seria supostamente "automática". Sobre o tema ver, entre outros, Jacomini, Márcia A. "A escola e os educadores em tempo de ciclos e progressão continuada" . Educação e Pesquisa v. 30, no. 3, p. 401-418, 2004. É interessante observar, ainda, como diversas entidades empresariais têm criado programas ou projetos visando contribuir para a melhoria do desempenho das escolas, de modo a melhorar os indicativos educacionais brasileiros, tidos unanimemente como muitos ruins. 


\section{ARGENTINA}

2.1. As normas legais sobre educação

O sistema educacional nacional argentino foi estabelecido em 1884, pela Lei 1420, e até 2003 não tinha passado por nenhum processo mais profundo de reorganização, segundo o próprio Conselho Federal de Educação daquele país ${ }^{43}$.

O Pacto Federativo Educativo (PFE), assinado em 11 de setembro de 1993, e a Lei Federal de Educação (LFE) ${ }^{44}$, aprovada no mesmo ano, são os dispositivos legais mais importantes sobre o assunto naquele país. No capítulo 1 do PFE, ficou estabelecido que o objetivo geral da educação é o de afiançar a identidade cultural como base estrutural e garantia da Unidade Nacional, integrando as particularidades provinciais e locais. É curioso observar que é apenas no quarto parágrafo que se fixa a justiça social como objetivo básico da educação e no parágrafo seguinte que se coloca a educação como promotora do desenvolvimento nacional ${ }^{45}$.

Outro ponto a destacar é que o PFE, ao definir as formas de financiamento do sistema, aponta para um fortalecimento das províncias e torna as escolas e colégios as unidades básicas de gestão, indicando uma intenção, ao menos teórica, de promover a descentralização do sistema educativo.

O Sistema Educacional Argentino está organizado em quatro níveis:

- Educação Inicial, compreendendo o Jardim de Infância, atendendo às crianças entre 3 e 5 anos.

- Educação Geral Básica (EGB), etapa obrigatória da escolarização no país, com 9 anos de duração, a ser iniciada aos 6 anos, e organizada em 3 ciclos (EGB 1, 2 e 3).

${ }^{43}$ Assembléia do Conselho Federal de Educação, de 27 de novembro de 2003.

44 Ambos os documentos estão disponíveis em www.meyc.gov.ar, na seção Legislação.

${ }^{45} \mathrm{Na}$ história argentina encontramos a explicação para o fato de a Identidade cultural nacional ser o primeiro objetivo da educação no país. Stella Maris S. Franco, analisando os manuais de história nacional argentinos entre 1868 e 1912, já chamou atenção para esse aspecto, destacando o papel que a disciplina de história desempenhou. Ver Franco, Stella M. S. Luzes e sombras na construção da Nação Argentina: os manuais de história nacional (1868-1912). Bragança Paulista: EDUSF, 2003. 
- Educação Geral Básica (EGB), etapa obrigatória da escolarização no país, com 9 anos de duração, a ser iniciada aos 6 anos, e organizada em 3 ciclos (EGB 1, 2 e 3).

- Educação Polimodal, cursada depois do EGB, oferecido por instituições específicas, com 3 anos de duração mínima.

- Educação Superior, Profissional e Acadêmica de Grau.

Já a LFE, (Lei 24195), define, em seu título I, Artigo 3, que o Estado nacional, as Províncias e a Municipalidade da cidade de Buenos Aires garantem o acesso à educação em todos os ciclos, níveis e regimes especiais a toda a população, mediante a criação, sustento, autorização e supervisão dos serviços necessários com a participação da família, da comunidade, suas organizações e iniciativa privada. No artigo 4 fica determinado que as ações educativas são responsabilidade da família, como agente natural e primário da educação, do Estado nacional, como responsável principal, dos municípios, da Igreja Católica, das demais confissões religiosas oficialmente reconhecidas e das organizações sociais, o que denota o importante papel que a Igreja Católica ainda desempenha naquele país, a ponto de merecer menção explícita nesse dispositivo legal.

No título II, sobre a Política Educativa, fica determinado que o primeiro direito, princípio e critério de orientação educativa é o fortalecimento da identidade nacional, atendendo às idiossincrasias locais, provinciais e regionais. Determina que tal política deve afiançar a soberania nacional, a consolidação da democracia, em sua forma representativa, republicana e federal, assim como deve promover o desenvolvimento social, cultural, científico, tecnológico e econômico do país. Há menção, ainda, sobre a necessidade dessa política promover a superação de todo estereótipo discriminatório nos manuais didáticos.

\section{2. Políticas públicas de universalização}

O PFE fixou o compromisso de universalização do atendimento educacional no país até 1999 , nos seguintes termos: atendimento de $100 \%$ das crianças e jovens entre 5 e 14 anos (EGB), e cobertura de 70\% dos adolescentes entre 15 e 17 anos (Polimodal). Sabemos que não foi possível alcançar essas metas, sobretudo depois que se agravaram os problemas financeiros do Estado argentino, no final de 2001. Foi preciso repactuar essas metas e em 2003 o 
governamentais (federal, provincial e municipal), mas buscou dar maior unidade a todo o sistema, estabelecendo os Conteúdos Básicos Comuns (CBCs) para todas as jurisdições educacionais. Embora não fossem determinados os conteúdos a serem abordados nas escolas, em cada um dos ciclos, a preocupação dos legisladores foi estabelecer uma estrutura curricular nacional, evitando a multiplicação do que os argentinos chamam de trayectos curriculares.

No caso do nível de ensino que nos interessa mais particularmente, o Ensino Médio, denominado Polimodal, deve ter uma carga horária mínima de 2700 horas, a ser cumprido em pelo menos três anos ${ }^{46}$. O currículo dessa etapa escolar pode ser composto por até 30 "espaços curriculares", entendendo por isso não matérias ou disciplinas, mas um conjunto de temas, de caráter interdisciplinar, articulados de modo a constituir um curso. Visava-se com isso reduzir o número de disciplinas que os alunos cursavam em cada um dos anos, que podiam chegar a catorze, com comprometimento da aprendizagem, pois as cargas horárias em vários casos eram muito pequenas (chegando a uma aula semanal). Ressalve-se, porém, que a reorganização curricular dá às escolas autonomia para completar a carga horária mínima com disciplinas que atendam às necessidades locais ou a um projeto próprio de cada unidade escolar, podendo mesmo vir a se articular com cursos técnicos profissionais, mas cuja carga horária é contabilizada à parte.

Percorrendo-se o texto que fixa os Conteúdos Básicos Comuns (CBCs) para o Polimodal, percebe-se claramente a sua organização por eixos temáticos, estruturados em módulos, para os quais são fixados objetivos gerais, conceituais, procedimentais e atitudinais. Definem-se competências que os alunos devem adquirir ao final de cada etapa ou módulo ${ }^{47}$, competências essas que devem prepara-los tanto para a vida social como profissional. No próximo capítulo detalharemos melhor os fundamentos que nortearam a reforma de ensino, especialmente no tocante ao Ensino Médio, realçando o fato de que os referenciais teóricos que orientaram a reforma Argentina foram, em boa medida, os mesmos que guiaram as reformas no Brasil e no México. Cabe ressaltar, desde já, que uma das motivações para essas reformas estava no fato de se

${ }^{46}$ O EGB3 e o Polimodal correspondem à antiga educação secundária, antes composta por 5 séries. Com a LFE, os dois primeiros anos dessa etapa passaram a compor a EGB e os outros três o Polimodal.

47 Cf. Conteúdos Básicos Comuns para o Polimodal, Conselho Federal de Cultura e Educação, 1996. Disponível em www.meyc.gov.ar 
referenciais teóricos que orientaram a reforma Argentina foram, em boa medida, os mesmos que guiaram as reformas no Brasil e no México. Cabe ressaltar, desde já, que uma das motivações para essas reformas estava no fato de se reconhecer uma grande inadequação entre o modelo de ensino então em prática e as necessidades do país na formação de quadros profissionais, ao mesmo tempo que esse modelo não mais atendia a uma nova parcela da sociedade que chegava ao Ensino Médio, cujas demandas e necessidades são de uma nova ordem.

\subsection{Perfil dos alunos}

O Censo Nacional de População, Residências e Educação, realizado em 2001, aferiu uma população de 34.262.181 indivíduos com 3 ou mais anos ${ }^{48}$, sendo que desse total, 11.171 .446 era atendida pelo sistema educacional argentino. No EGB3, considerada, como vimos, primeira etapa da educação secundária, estavam matriculados 2,2 milhões de alunos, enquanto que nos cursos do Polimodal haviam outros 1, 4 milhões de jovens. A população entre 15 e 17 anos era de 1.921.972, sendo que 1.526.049 estava sendo atendida pelo sistema educacional. Uma parcela esmagadora, 1.403.349, morava em zonas urbanas $^{49}$.

Para uma população de 26.012.435 pessoas com 15 anos ou mais, 4,2 milhões haviam terminado o curso secundário (equivalentes aos atuais EGB3 e Polimodal), o que representava $58 \%$ do total de ingressantes, indicando um importante avanço na escolaridade da população, pois em 1991 esse percentual era de $37 \%^{50}$.

De fato, assim como no Brasil, durante mais de um século, a educação secundária foi restrita aos filhos da elite argentina. Por esse motivo, calcava-se em um modelo clássico de educação preparatória para o ensino superior, em que ciências e humanidades se mesclavam. Havia pouca preocupação, nesses

\footnotetext{
48 No total, a população Argentina era de 36.260.130 habitantes.

49 Segundo as normas do censo, considerou-se zona urbana toda aquela que contava mais de 2 mil habitantes.

50 Cf. Censo Nacional de Población, Hogares y Vivendas de 2001. Dados obtidos em www.indec.mecon.gov.ar.
} 
cursos, com uma formação profissional, sendo essa garantida por cursos técnicos de outra modalidade.

Fernández, Finocchio e Fumagalli ${ }^{51}$, informam, em um recente estudo, que nos últimos 30 anos, a educação secundária teve uma forte expansão na Argentina. Enquanto em 1960 apenas 24,5\% dos adolescente e jovens entre 13 e 18 anos freqüentavam uma escola desse nível, em 1996 esse percentual havia atingido 67,2, o que colocava aquele país, junto com o Uruguai e Chile, como os que melhor atendiam essa faixa etária na América do Sul ${ }^{52}$. Uma das conseqüências dessa expansão é que entre 1980 e 1991 o tempo médio de escolarização naquele país passou de 9,7 anos para 10,3 anos. Em termos de número de matriculados, os censos educativos de 1994 e 1998 apontavam 2.144.372 alunos no primeiro ano e 2.539.749 no segundo.

Uma expansão dessa magnitude indica que um novo estrato social passou a ter acesso à educação secundária, em um movimento bastante semelhante ao que vimos no Brasil. As mudanças econômicas tiveram importante papel para tanto, embora também tenham gerado um paradoxo, assinalado por Daniel Filmus: quanto mais necessária ela se tornou para assegurar uma melhor condição social e profissional aos indivíduos, mais insuficiente ela acabou se convertendo para a formação dos jovens, mostrando um aspecto perverso da democratização da educação, o que, diga-se, não é próprio apenas da Argentina ${ }^{53}$.

Dados de 1999 apontavam que 70\% dos matriculados no Polimodal freqüentavam escolas públicas, frente a outros 30\% que estudavam em escolas privadas $^{54}$. Percentual semelhante se verificava em 1980, com a diferença que àquela época a esfera federal atendia $45,2 \%$ e os governos provinciais $24 \%$, e em 1999 todos os alunos que estavam no sistema público freqüentavam escolas mantidas por essa esfera governamental, ainda que com aportes expressivos do

${ }^{51}$ Fernandéz, Ana Lia; Finocchio, Silvia e Fumagalli, Laura. "Cambio de la educaión secundaria em la Argentina". In Braslavsky, Cecília(Org.). Op. Cit, p.407-466.

52 A excelência do sistema argentino pode ser aferida pela cobertura de $98 \%$ das crianças no nível pré-escolar e 100 no nível primário, segundo dados de 1998. É provável, porém, que os problemas enfrentados pelo país nos anos mais recentes tenha provocado alguma piora nesses indicadores.

53 Filmus, Daniel. Cada vez más necesária,cada vez más insuficiente - escuela media y mercado de trabajo en épocas de globalización. Argentina: Santillana, 2001.

${ }^{54}$ Grande parte das instituições privadas que oferecem cursos polimodais são religiosas. 
governo central. Esse crescente protagonismo das províncias, denota uma descentralização do sistema, com a conseqüente autonomização na organização de suas redes, com evidentes desdobramentos políticos, como realçam as três autoras mencionadas ${ }^{55}$. Uma dessas conseqüências é a coexistência de realidades provinciais ou locais bastante variadas, o que faz as mesmas autoras afirmarem que

Como consecuencia de esa diversidad de estrategias para la extensión de la obrigatoriedad escolar y para la gestación del tercer ciclo y del Polimodal, actualmente existe una gran heterogeneidad nacional relacionada con: la modalidad de transformación de la educación secundaria preexistente tanto en tercer ciclo de la EGB como en el Polimodal, la localización [física] del tercer ciclo, su dependencia administrativa, la definición de la estructura curricular y otros aspectos. ${ }^{56}$

Ou seja, do pondo de vista do funcionamento das escolas, há uma grande variedade de situações, em que a antiga estrutura ainda convive com a nova, o que dificulta uma melhor avaliação da situação nacional como um todo.

Outro problema sério é que continua elevado o índice de evasão e repetência, bem como a baixa qualidade das aprendizagens ${ }^{57}$. Cerca de $20 \%$ dos alunos do Polimodal são reprovados, cerca de 5\% repetem e outros quase $15 \%$ abandonam seus estudos a cada ano, segundo dados de 2002. Segundo Cecília Braslavsky ${ }^{58}$, diversos estudos têm demonstrado que a falta de adequação entre as demandas e necessidades dos jovens e o modelo da escola secundária - e isso não apenas na Argentina - tem se constituído em causa relevante de abandono escolar e baixos índices de aprendizagem. Em um exame nacional, semelhante ao Exame Nacional do Ensino Médio (ENEM) brasileiro, realizado em 2000, os alunos tiveram média de 63,3 em matemática e 59,1 em castelhano, o que pode ser uma prova desses baixos rendimentos.

\footnotetext{
55 Idem, pp. $425-431$.

Idem, pp. $429-430$.

Idem, p. 408.

58 Braslavsky, Cecília. "Los procesos contemporâneos de câmbios de la educación secundaria em América Latina: análisis de casos em América del Sur". In Braslavsky, C. La educación secundaria ¿Cambio o inmutabilidad? Op. Cit. p. 233.
} 
As reformas curriculares promovidas nos anos 1990 tiveram como uma das metas principais reverter esse quadro, mas os resultados não são de todo satisfatórios, como veremos no próximo capítulo ${ }^{59}$.

\subsection{Perfil dos Professores}

A formação docente para a EGB1 a EGB2 é diferente daquela exigida para os professores da EGB3 e do Polimodal. Até mesmo a nomenclatura muda: enquanto os primeiros são chamados de maestros, os segundos são denominados de professores. Contudo, apesar de terem formação superior, esses professores não necessariamente têm curso universitário, ainda que devessem tê-lo.

Além das modificações na estrutura de ensino e nos currículos, verificou-se na Argentina desde os anos 1990 diversas iniciativas no sentido de ampliar a capacitação profissional dos professores, tanto daqueles que atuam nas diversas etapas da EGB como no Polimodal. Segundo Fernandéz, Finocchio e Fumagalli, boa parte dessas iniciativas não redundou em melhoria efetiva, entre outros motivos porque não superaram o formato que elas denominaram de "cursillista", no sentido de constituírem um momento recortado da rotina de trabalho dos professores, pouco alterando-a. Parece ser esse um entrave para a melhoria da qualidade das aprendizagens naquele país: apesar de contar com um corpo docente qualificado ${ }^{60}$, um grande número de professores, cuja prática cristalizouse dentro de certos modelos educativos ou que, por pertencerem a estruturas funcionais rígidas, têm pouca disponibilidade para mudanças, pouco alteraram sua prática de sala de aula, apesar das reformas em curso. Por outro lado, os professores deveriam passar a cumprir sua carga horária semanal de trabalho a partir de uma nova regulamentação, de modo a poder exercer outras atividades além das aulas propriamente, como as tutorias (orientação direta de alunos), componente importante da nova proposta educacional. No entanto, isso não se efetivou, o que também contribui para dificultar ou desestimular mudanças.

59 Um bom quadro das questões sociais, culturais e econômicas que envolvem esse nível escolar é encontrado em Barbosa, Ricardo et al. Educación Media y cultura adolescente - Desafio del siglo XXI. Buenos Aires: Academia Nacional de Educación, 2003.

60 Apesar de grande parte dos professores terem curso superior, parte deles não conta com a formação adequada quando se trata de conteúdos tecnológicos e de inglês, cujas cargas horárias se ampliaram na reforma. Cf. Fernandéz, Finocchio e Fumagalli, op. cit, p. 437. 
Outro importante aspecto a destacar é que os professores que atuam nos cursos Polimodal são em número insuficiente para uma demanda crescente. Some-se a isso o fato de que grande parte deles teve uma formação clássica, com base disciplinar, e durante décadas atuou em uma estrutura escolar assentada nas asignaturas. Portanto, um importante ponto a ser enfrentado é a melhor articulação entre o sistema educacional e a formação de novos professores, de modo, que, por um lado, esses não enfrentem dificuldades para desenvolver os novos programas estabelecidos, e, por outro, seja possível ampliar rapidamente o número de habilitados para o magistério. Uma importante iniciativa com tais propósitos foi a reforma dos cursos de Formação Docente, algo equivalente aos cursos de licenciatura no Brasil. Segundo o novo desenho curricular desses cursos, definido pela Lei de Educação Superior de 1995, eles devem ser constituídos por conteúdos básicos mínimos, mas a formação dos professores deixa de ser orientada por uma única ciência de referência para assumir claramente um perfil multidisciplinar, além de enfatizar aspectos relacionados a ciência e tecnologia. Desse modo, ao final do curso, os professores adquirem uma habilitação principal e outra complementar. No caso específico das Ciências Sociais, por exemplo, eles podem ministrar aulas de História e Economia, ampliando suas chances de colocação profissional, ao mesmo tempo que possibilita que um mesmo professor atenda, legalmente, a diversos espaços curriculares definidos pela escola ${ }^{61}$.

Infelizmente, não é possível traçar um perfil mais detalhado dos professores, pois as mudanças administrativas e as reformas dos últimos anos fragmentou a estrutura docente do país, a ponto do atual ministro da Educação, Daniel Filmus, um importante especialista em educação secundária, afirmar em um entrevista que era impossível ter uma noção correta sobre a realidade docente em todo o país $^{62}$. Os professores totalizavam, segundo uma primeira contagem do censo Educacional, pouco mais de 560 mil, atuando em cerca de 41 mil estabelecimentos $^{63}$.

61 Sobre essa questão, ver Plan Nacional Plurianual de Ciencia y Tecnologia 1998-2000. In www.secyt.gov.ar/planplur/seceduca.htm.

62 Jornal La Prensa, edição on line de 26.10.2004.

63 O Ministério da Educação e Cultura realizou em 2004 um grande censo visando estabelecer um quadro mais amplo e preciso da realidade educacional do país. 


\title{
3. MÉXICO
}

\subsection{O Ordenamento legal educativo}

Desde agosto de 1993, estabelece o Artigo $3^{\circ}$. da Constituição Mexicana:

Todo o indivíduo tem direito a receber educação. O Estado Federação, Estados e Municípios oferecerão educação pré-escolar, primária e secundária. A educação primária e a secundária são obrigatórias.

\author{
A educação oferecida pelo Estado deverá desenvolver \\ harmonicamente todas as faculdades do ser humano e fomentará \\ igualmente, o amor à Pátria e a consciência da solidariedade internacional, \\ a independência e a justiça ${ }^{64}$.
}

Os oito incisos que se seguem, detalham esse importante direito dos cidadãos mexicanos, cabendo destacar um aspecto muito caro à história da educação naquele país: a educação pública deve ser necessariamente gratuita e laica ${ }^{65}$.

O segundo artigo constitucional a tratar da educação, o Artigo 31, determina que é obrigação dos mexicanos:

Fazer com que seus filhos ou pupilos freqüentem as escolas públicas ou privadas, para obter educação primária e secundária, e recebam a militar, nos termos estabelecidos pela lei.

${ }^{64}$ Articulo $3^{\circ}$ Constitucional y Ley General de Educación. México: Secretaria de Educação Pública (SEP), 1993. A alteração constitucional ocorrida naquele ano inseria-se no conjunto de reformas educacionais promovidas pelo governo federal, visando moderniza-la e ampliar o atendimento à população. A Constituição mexicana atual foi aprovada em 1917.

65 Segundo Raúl Bolaños Martinez, a conquista da educação laica e pública foi assegurada pelo povo mexicano desde a aprovação da Lei Orgânica de Instrução Pública de 1869, ainda que a Constituição de 1857 já contemplasse esse princípio. Cf. Martínez, Raúl B. "Origenes de la educación pública en México". In: Solana, Fernando et al. Historia de la educación pública en México. México: Fondo de Cultura Económica, 1997, p.32. A importância e o significado político dessa laicização da educação, inclusive no nível superior, é explicada por Maria Ligia C. Prado no capítulo 4 de seu livro América Latina no século XIX: Tramas, Telas e Textos, São Paulo: EDUSP, 2004. 
O sistema educativo mexicano assegura, desde aquela data, como dever do Estado o fornecimento de educação pública até o ensino secundário ${ }^{66}$, ainda que a escolarização não se encerre nesse nível. A organização educacional atual no México assim se estrutura:

- Ensino Básico, composto de 9 anos obrigatórios, antecedidos por outros três de educação infantil ${ }^{67}$, sendo que os últimos três anos recebem o nome de ensino secundário.

- Ensino Médio Superior, com duração de três anos.

- Ensino Superior.

Até 1993, o ensino secundário, por fazer parte do nível médio de ensino, não era obrigatório ${ }^{68}$. Cada uma das duas etapas que o constituía tinha duração de três anos, e seus currículos eram claramente voltados para uma formação propedêutica, visando a preparação para o curso superior. Contudo, mudanças econômicas, mais especificamente no mercado de trabalho, começaram a exigir uma mão-de-obra mais qualificada ${ }^{69}$. Ao mesmo tempo, como muitos jovens precisavam ingressar nesse mercado, de modo a contribuir com a renda familiar, entendia-se ser necessário ampliar a formação profissional, especialmente nos ramos técnicos. Havia, assim, pressões sociais e políticas pela universalização do ensino secundário, ampliando a cobertura de atendimento nesse nível de ensino, até então bastante limitada. Desse modo, com a reforma educacional de 1993, a

${ }^{66}$ A educação primária tornou-se constitucionalmente obrigatória em 1934, como informa a exposição de motivos da Reformas Constitucionais do Presidente Salinas de Gortari.Artículo $3^{\circ}$. Constitucional y Ley General de Educación. México: Secretaria de Educação Pública (SEP), 1993, p. 14.

67 Embora seja obrigação do Estado oferecer escolas de Educação Infantil para as crianças de 3 a 5 anos, ela não é obrigatória, pois os legisladores entenderam que as famílias poderiam querer encarregar-se sozinhas dessa etapa da formação. Artículo $3^{\circ}$. Constitucional y lei General de Educación. Op. cit. p. 19.

68 A mudança ocorreu quando da aprovação da Ley General de Educación, aprovada em 13 de julho de 1993, durante a gestão de Ernesto Zedillo como Secretário da Educação (presidência de Carlos Salinas de Gortari). Essa lei equivale à Lei de Diretrizes e Bases da Educação brasileira, regulamentando toda a educação no país (dispositivos infra-constitucionais).

69 É interessante registrar que, constitucionalmente, nenhum mexicano pode ser privado do acesso ao trabalho em razão da sua não escolarização ou escolarização incompleta. Em sua exposição de motivos ao Congresso, quando do envio do projeto da referida lei, afirma o presidente: "em este sentido, dichos niveles de educación no se convierten em requisito para obtener trabajo, ejercer los derechos políticos o ejercer la pátria potestad sobre los hijos. Para los indivíduos, la educación es un deber social cuya única sanción reside en un más limitado desarrollo de la persona." Artículo $3^{\circ}$. Constitucional y Ley General de Educación, op. cit. p.21. 
escolaridade obrigatória estendeu-se para o ensino secundário, cujos currículos podem conter uma parte técnica profissionalizante ${ }^{70}$.

A Educação Média Superior (EdMS), entretanto, continua não fazendo parte da escolaridade obrigatória e, por extensão, não há exigência constitucional para que o Estado, em suas três instâncias, ofereça vagas a todos os jovens em idade de cursá-la. Nem por isso, entretanto, é desprezível o número de alunos que freqüentam essa etapa escolar. Segundo o relatório da Secretaria de Educação Pública - SEP -, no período letivo de 1998/1999, estavam matriculados 2,8 milhões de alunos, nas mais de dez mil escolas de Educação Média Superior do país, o equivalente a cerca de $10 \%$ do total de estudantes do Ensino Básico. Apesar da magnitude dos números, eles não representavam mais do que $50 \%$ do total de jovens entre 16 e 18 anos do país ${ }^{71}$. Ainda que haja esforço das autoridades educacionais para ampliar esse atendimento, o maior desafio, atualmente, é o de ampliar o acesso ao nível secundário, cuja cobertura está mais próxima de ser universalizada ${ }^{72}$

Não fazendo parte da Educação Básica, a Educação Média Superior não se subordina à SEP, órgão equivalente ao nosso Ministério da Educação. Há instâncias deliberativas descentralizadas, ainda que caiba à SEP o repasse de verbas e a avaliação dos materiais didáticos, por exemplo. Além disso, desde 1979 foi criado pela SEP um órgão de Coordenação Nacional para Planejamento e Programas da Educação Média Superior - CONPPEMS - com o objetivo de combater a dispersão e discrepâncias dentro do sistema. Nos anos 1990, esse órgão passou por reformulações, passando a se chamar Coordenação Nacional

70 O ensino secundário é oferecido nas seguintes modalidades: geral, para trabalhadores, telesecundária, técnica e para adultos. Essa última é oferecida aos maiores de 16 anos, que não podem cursar as classes regulares a partir dessa idade, exceto se não interromperem sua escolarização. Perfil de la Educacion en México. México: SEP, 2000, P. 23.

71 Cf. Prieto, Ana Maria. "La educación Media Superior".In: Bertussi, Guadelupe T. Anuário Educativo Mexicano: Visión retropspectiva (Tomo I). Mexico: Universidad Pedagogica Nacional, 2001.

72 Dados da SEP dão conta que a rede escolar atende a mais de $90 \%$ da população que deveria ingressar no nível secundário ( por ter concluído o primário), mas apenas $65 \%$ do jovens com 18 anos conseguem concluir essa etapa escolar, denotando que, além de aumentar o empenho para garantir o acesso, deverá ser grande o esforço das autoridades para diminuir o elevado índice de evasão escolar. Ver Perfil em la educación em México. México:SEP, 2000. O periódico Educação 2001_em dezembro de 2003 dedicou todo um número à análise do Nível Secundário e, no editorial, informa-se que somente $70 \%$ dos jovens entre 16 e 18 anos são atendidos. Outro dado apresentado no mesmo editorial é que parcela expressiva dos que abandonam as salas de aula (mais de $20 \%$ deles), o fazem porque não gostam da escola, e não por motivos econômicos, conforme apurou a Pesquisa Nacional da Juventude. Educação 2001- Revista Mexicana de Educação. No. 103, p.9, dez. 2003. 
da Educação Média Superior - CONAEMS -, formada por representantes dos estados da federação ${ }^{73}$.

A EdMS é requisito obrigatório para se ingressar no curso superior e é oferecido em três modalidades ou subsistemas:

Bachillerato geral ou propedêutico - dividido, por sua ver em:

- Escolas Preparatórias

- Colégio de Bachilleres

- Preparatória Aberta ( para adultos)

- EdMS à Distância (destinada a comunidades pequenas, que não tenham uma unidade escolar)

- Educação Profissional Técnica ${ }^{74}$

- Bachillerato tecnológico - modalidade bivalente, fornecendo formação propedêutica e profissionalizante.

Espera-se que os alunos ingressem aos 16 anos nessa fase escolar e a concluam aos 18. Aqueles que fazem uma modalidade propedêutica podem concorrer a uma vaga em um curso superior, mediante a avaliação de seu currículo. Em tese, todos os aprovados na terceira série da EdMS têm assegurada sua vaga universitária, mas em alguns cursos mais concorridos, o acesso é mais difícil, exigindo em certos casos a realização de um exame de ingresso. Assim, pode-se dizer que o verdadeiro funil do sistema educacional mexicano ocorre quando da seleção para ingresso nas melhores instituições que oferecem EdMS, pois um certificado de conclusão em uma delas, sobretudo com boas notas, garante acesso a qualquer carreira na Universidade Nacional Autônoma do México (UNAM), a maior e mais importante instituição acadêmica (pública) do país. Cabe mencionar que os dois cursos de EdMS com maior prestígio e, por isso mesmo, os mais disputados, são oferecidos pela própria UNAM (portanto,

não por motivos econômicos, conforme apurou a Pesquisa Nacional da Juventude. Educação 2001- Revista Mexicana de Educação. No. 103, p.9, dez. 2003.

73 Cf. Castanón y Seco. La educación media superior en México. Mexico: Noriega Editores, 2000, p. 98.

74 Essa modalidade é terminal, não fornecendo habilitação para um curso superior. 
com recursos federais): os cursos das Escolas Nacionais Preparatórias (ENPS), criados em 1867, e os Colégios de Ciências Sociais ( $\mathrm{CCHs}$ ), criados mais recentemente, em $1971^{75}$. Somente as ENPs atendem cerca de 40 mil alunos, espalhados por 9 unidades. A maior delas tem 11 mil alunos. Já os CCHs atendem outros 50 mil alunos aproximadamente, em cinco unidades. Outros cursos bastante disputados são aqueles oferecidos pelo Instituto Politécnico Nacional, que possui 15 centros de Estudos Científicos e Tecnológicos, que proporcionam formação para aqueles que desejam ingressar nas carreiras de Ciências Exatas e Biológicas, mas obtendo formação profissional ao final da EdMS ( currículo bivalente).

Para ingressar nas ENPs ou nos CCHs os alunos precisam se submeter a um exame unificado e, dependendo da nota, ele é encaminhado para uma das opções que ele próprio indicou. Muitos não conseguem entrar onde desejavam (cada unidade oferece currículos diferenciados, com maior ênfase em uma área, e algumas são consideradas como fornecedoras de melhor nível educacional), vendo-se obrigados a fazer o curso em uma ENP de menor prestígio. Ainda assim, elas desfrutam de maior reconhecimento do que os Colégios de Bachilleres (CBs), em geral modalidade financiada pelos governos estaduais, com aportes do governo federal $^{76}$. Como as ENPs e os CCHs são oferecidos apenas no Distrito Federal, muitos jovens precisam deixar suas cidades para freqüenta-los.

A estrutura curricular dessas diversas modalidades de EdMS é bastante complexa ${ }^{77}$, o que é visto, inclusive, como um dos mais graves problemas a serem enfrentados pelas autoridades educacionais, pois há pouca mobilidade de um subsistema para outro. Apenas para dar um exemplo: um jovem que ingressa em um Centro de Estudos Tecnológicos Industriais e de Serviço bivalente, enfrenta dificuldades para transferir-se para um curso similar, mas apenas de natureza

75 Castrejón Diez, Jaime. "El bachillerato". In: Sarre, Pablo Latapi (Coord). Un siglo de educación en México. México: Fondo de Estudios e Investigaciones Ricardo J. Zevada/Fondo de Cultura Econômica, 1997., pp. 283 e 289.

76 Em geral, os custos operacionais das unidades, incluindo o pagamento dos professores, são cobertos pelos governos das unidades federadas, Cf. Perfil de la educación em México, Op. cit. p. 65. Em 2000 havia 450 unidades de CBs em todo o país, Cf. Castanón Y Seco, Op. cit., p. 32.

77 Há mais de 300 programas diferentes em todo o sistema, oferecidos por cerca de 860 instituições, outorgando diplomas com mais de 730 denominações diferentes cf. Castanón y Seco: idem, ibidem. 
profissionalizante ou vice-versa. Nesses casos, será preciso refazer boa parte das disciplinas, dadas as diferenças de carga horária e dos currículos ${ }^{78}$.

De todo modo, todas as escolas de EdMS têm um núcleo curricular comum, visando uma formação básica. História faz parte desse núcleo, mas a carga horária pode variar.

O forte processo seletivo, além da sua concentração na capital ${ }^{79}$, por si só fazem os cursos de Bachillerato Geral uma etapa acessível apenas para uma parcela privilegiada da sociedade, sobretudo dos centros urbanos maiores. Além disso, seu caráter exclusivamente propedêutico, voltado para a preparação para o curso universitário, acentua ainda mais esse caráter elitista dos cursos ${ }^{80}$. Curiosamente, porém, a maioria dos concluintes do ensino secundários (57\%) opta por um dos vários cursos dessa modalidade ${ }^{81}$, enquanto outros $28 \%$ escolhem uma opção bivalente. Somente $15 \%$ fazem cursos técnicoprofissionalizantes, o que os impede de seguir uma carreira universitária. Considerando a fonte de financiamento dessas escolas, $80 \%$ dos estudantes freqüentam escolas públicas, enquanto escolas privadas atendem $20 \%$ deles $^{82}$.

\subsection{Perfil dos alunos}

De acordo com o censo realizado em 1991, cerca de 9,3 milhões de jovens mexicanos contavam entre 15 e 19 anos; portanto, pouco mais de $11 \%$ da população tinha idade para cursar a EdMS. Uma parcela expressiva, porém, não freqüentava a escola, contrastando com a parcela entre 6 e 14 anos, que era

78 Cf. Castanón y Seco. Op. cit. p. 240.

79 Não só há concentração dos cursos na capital, como se verifica uma distribuição heterogênea entre e nos estados.

80 Um importante indicador do caráter elitista da EdMS é que a SEP reconhece que são as famílias de renda média e alta e não as de renda menor que mais se beneficiam com os gastos públicos nesse nível escolar. Esse dado ganha ainda mais significado quando sabemos que as famílias que constituem a parcela dos 10\% com maior renda no país empregam cerca de 16\% dessa renda em educação, enquanto o decil com a menor renda despende 8,5\%, denunciando o perverso mecanismo de concentração de renda embutido em tal sistema escolar. Enquanto a SEP gastou em $1996 \$ 3.315 .50$ pesos por aluno da Educação Básica (perfazendo 65\% dos gastos totais do órgão), com cada aluno da EdMS foram gastos 5.893,40 (correspondente à 9,5\% do total de gastos) Ver Perfil de la educación en México. Op. Cit. P.126,132-134.

81 A escolha predominante por cursos propedêuticos se deve à defasagem entre o que é oferecido nos cursos profissionalizantes e as exigências do mercado de trabalho, Cf. Castanón Y Seco, idem, p. 33.

82 Dados do Informe de labores $1997 / 98$ da SEP, apud Castanón Y Seco, idem, p. 81. Durante o governo Fox, parece ter havido uma campanha de desvalorização do ensino público, com a conseqüente valorização das instituições privadas, o que tenderia a ampliar a participação das escolas particulares. 
atendida em mais de $90 \%$ pelo sistema de ensino ${ }^{83}$. Um dos fatores que muito contribuía para essa situação era o fato de mais de 33\% daquele contingente viver em pequenas localidades, onde não havia escolas desse nível de ensino. Embora constituíssem um grupo pequeno - cerca de $8 \%$ do total da população indígena os jovens entre 15 e 19 anos que pertenciam a essas comunidades e não falavam o espanhol tinham nessa condição uma outra barreira para estudar.

Um estudo realizado pela UNAM entre 1991 e 1993 revelou que a maior parte dos alunos que freqüentavam seus cursos de bachirellato provinham de famílias compostas em geral de 4 a 6 membros, em que os pais no máximo tinham concluído o nível primário ${ }^{84}$. Em muitos casos, o sustento era garantido pelos rendimentos apenas do pai, uma vez que as mães dedicavam-se aos trabalhos domésticos sem obter outros rendimentos. Portanto, do mesmo modo que verificamos no Brasil e na Argentina, nas últimas décadas vem crescendo a parcela de estudantes cujas famílias pela primeira vez atingem um maior nível de escolaridade.

Entretanto, é bastante alto o índice de evasão, havendo uma diminuição expressiva do número de matriculados em cada uma das três séries, o que redunda no fato de que apenas $55 \%$ dos alunos conseguem o certificado de conclusão. Segundo uma pesquisa com alunos de 215 escolas públicas e privadas $^{85}$, a evasão é maior nos cursos técnicos (48\%), quando comparada com a dos cursos de bachillerato (25\%),

A idade média dos estudantes, segundo a mesma pesquisa, é de 17 anos, o que contrasta com a realidade dos estudantes brasileiros, e a maioria apenas estuda. Naturalmente que a minoria que precisa trabalhar enfrenta uma situação mais difícil para prosseguir os estudos, e entre eles a evasão é maior.

${ }^{83}$ Segundo o Censo de 1995, mais de $70 \%$ dos jovens entre 15 e 24 anos não estudavam, enquanto que entre aqueles que tinham entre 6 e 14 anos esse percentual era de menos de 8\%. Cf. Castanón R. y Seco, Rosa. Op. cit. p.66.

${ }^{84}$ Segundo o levantamento, enquanto 5.182 alunos tinham pais com nível superior de educação, outros 9.152 tinham pais que concluíram o secundários e o de outros 14.886, tinham estudado até o primário. No presente, esses percentuais continuam semelhantes .Cf. Castanón R. Y Seco, R. Op. Cit. p. 72. Não é descabido pensar que, por se tratar de uma instituição de excelência, com acesso muito seletivo, a realidade do sistema nacional como um todo deve apontar para uma parcela ainda maior de estudantes cujos pais têm uma baixa escolaridade.

85 A pesquisa foi parte do projeto que redundou na publicação da obra La Educación Media Superior en México. 
De acordo com a auto-avaliação dos próprios pesquisados, eles têm dificuldades para realizar leituras mais prolongadas, para redigir trabalhos escolares, fazer uso de computadores e para fazer uso de informações de revistas e jornais. Por outro lado, eles consideram não ter dificuldade para expressar-se oralmente nem para entender seus livros didáticos. Mais expressiva, contudo, é a revelação de que parcela expressiva dos entrevistados disse não ter certeza da utilidade do que estavam estudando ${ }^{86}$.

\section{3. Perfil dos professores}

Legalmente, todo professor no México deve ter nível superior, ou seja, deve ter pelo menos o Curso Normal ${ }^{87}$. Na prática, contudo, isso ainda está longe de se constituir realidade. Especialmente nas pequenas comunidades, nos estados mais pobres, é grande o número de professores da Escola Básica que apenas concluíram a EdMS ou não completaram o Curso Normal. Há os que nem mesmo essa formação dispõem. De modo semelhante ao Brasil, a formação dos professores e as políticas governamentais de estímulo ao magistério não atraem para a carreira os estudantes mais qualificados ${ }^{88}$.

No caso da EdMS, há algumas diferenças relevantes. Primeiro, do ponto de vista legal, os professores precisam ser licenciados ${ }^{89}$, ou terem feito o curso Normal com especialização no ensino de uma disciplina (no nosso caso, em História). Portanto, esses professores encontram-se no grupo dos mais bem preparados (ou com melhor formação acadêmica) do país ${ }^{90}$. Segundo, que o Ensino Médio desfruta de maior prestígio do que a Educação Básica; por isso, dar

${ }^{86}$ Castanón R. Y Seco. R. Op. cit. p. 173. No questionário, os alunos deveriam atribuir uma pontuação de 0 a 100 para a pergunta sobre a certeza da utilidade do que estavam aprendendo. A média foi de 46 pontos.

87 No México denomina-se de curso Normal o que em nosso sistema equivaleria ao curso de Pedagogia. Ele tem duração de 4 anos.

88 Uma boa avaliação dos problemas relacionados aos professores pode ser encontrado em Educação 2000, Revista Mexicana de Educação, de dezembro de 2003.

89 No México o título de licenciado corresponde ao nosso bacharel.

90 A pesquisa realizada para a elaboração da obra La Educación Média Superior: uma invitación a la reflexión, chegou aos seguintes resultados: $58 \%$ dos professore tinham curso completo de licenciatura; cerca de um terço deles continuava estudando, fazendo mestrado ou mesmo uma segunda licenciatura. Outro $1 / 4$ disse estar fazendo cursos livres. No entanto, a pesquisa identificou professores que não tinham o título de licenciados (mas não se menciona a percentagem). Os professores reconheceram que nas escolas em que atuavam eram oferecidas oportunidades para aperfeiçoamento profissional, especialmente no tocante a aspectos pedagógicos, mas cerca de $15 \%$ achava que elas pouco ou nada ajudavam no seu trabalho cotidiano. A pesquisa identificou, ainda, um baixo grau de adesão dos professores (cerca de 25\%) aos programas de promoção profissional, que incluem cursos de aprimoramento profissional. Cf. Castanón y Seco. Op. cit. p. 175. 
aulas para alunos dessa etapa escolar confere distinção, razão pela qual muitos professores ambicionam lecionar nesse nível escolar.

Um outro aspecto importante a ser mencionado, no caso específico de História: os cursos de Licenciatura, até o período letivo de 2003-2004, não privilegiavam a formação de professores, ainda que sabidamente a maior parte dos alunos tenha essa carreira como opção profissional. Desse modo, apesar de terem uma competente formação na área, não se encontram plenamente habilitados para exercer o magistério. Segundo o Coordenador do Departamento de História da ENPs, em entrevista à autora ${ }^{91}$, a partir do período letivo 2004/2005 a UNAM oferece um currículo específico para formar docentes tanto para o Ensino Secundário como para a EdMS. Com isso se espera superar o sério problema de qualificação profissional para esses dois níveis de ensino e, não menos importante, estimular uma renovação nos quadros dos professores da EdMS, cuja idade média, segundo ele, é alta ${ }^{92}$, motivo, inclusive, ao qual ele atribui a resistência para que importantes mudanças curriculares e de metodologia de ensino ocorram.

No tocante à carga horária de trabalho, a partir da reforma instaurada pelo Acordo Nacional para a Modernização da Educação Básica, de 1993, os programas curriculares passaram por mudanças. A antiga área de Ciências Sociais passou a ser composta por História, Geografia e Civismo, o que trouxe impactos e debates importantes. Por um lado, os professores que lecionavam nas escolas secundárias não conseguiam mais compor sua carga horária semanal trabalhando em uma ou no máximo duas escolas, como vinham fazendo, dando aulas tanto de História, como de Geografia e Civismo, independente de sua formação acadêmica. A partir daquela data, as aulas de História - 3 por semana, para cada uma das três séries, com 50 minutos de duração - só poderiam ser dadas por licenciados nessa disciplina, o mesmo ocorrendo com os professores

91 A entrevista com o Prof. Carlos Amya foi realizada no dia 15 de dezembro de 2003.

92 A principal causa da permanência dos professores nas suas cadeiras, mesmo depois de atingirem idade para aposentadoria, são os baixos salários. Parte de sua remuneração advém do programa de estímulo profissional aos mestres, que proporciona valores adicionais para aqueles que realizam pesquisas. Esses acréscimos são perdidos quando o professor aposentase. Uma das principais conseqüências disso é, segundo o Coordenador do Depto. de História da ENP, a manutenção de abordagens tradicionais, assentadas sobretudo no plano político. 
de Geografia. Conseqüentemente, para conseguir compor sua jornada de trabalho, o professor passou a lecionar em duas, três ou até quatro escolas, de modo a completar sua jornada de trabalho ${ }^{93}$, o que nos permite concluir que as condições de trabalho e de vida dos professores está longe do desejável.

\subsection{Políticas públicas}

A EdMS não contava, até 2004, com uma política mais concertada, visando enfrentar os diversos problemas, como a ampliação da cobertura, com o consequente aumento da escolarização média da população. O fato das etapas anteriores, mais especificamente a educação secundária, constituir atualmente um foco de ação política mais forte, visando sua universalização, associado ao fato de que a EdMS conta com uma relativa autonomia frente a SEP, explicam esse relativo desinteresse. Ainda assim, diversas iniciativas, como os estudos que resultaram na publicação do livro La Educación Media em México, de que muito nos valemos, indicam uma crescente preocupação em se realizar um plano de ação mais consistente, de modo que o país possa fazer frente aos desafios sociais e econômicos da atualidade. A condição singular daquele país no enfrentamento das inúmeras situações decorrentes da globalização, uma vez que a proximidade com os Estados Unidos coloca para os mexicanos problemas bastante complexos, como a emigração, tem exigido dos governantes, e em especial das autoridades educativas, a adoção de uma política mais articulada para o Ensino Médio. A julgar pelas conclusões apresentadas por Roberto Castanón e Rosa Maria Seco no referido estudo, o modelo que se pretende construir aponta para grandes e profundas transformações, de modo a proporcionar aos jovens mexicanos uma educação bastante diferente daquela que se vê no presente.

${ }^{93}$ No México, os professores assinam contratos de trabalho em que se determina o número de horas semanais de trabalho. No segundo semestre de 2004 a SEP anunciou uma nova reestruturação curricular no nível secundário, alterando novamente a composição de aulas dos professores, mas agora no sentido inverso do que ocorrera anteriormente. Segundo essa proposta, toda a carga horária de História se concentraria no segundo ano, o que representaria para os professores o mesmo número de horas aula, mas uma expressiva diminuição no número de classes e alunos. 


\section{UNIDADE E DIVERSIDADE}

Depois de termos apresentado um quadro geral da educação nos três países, alguns aspectos merecem ser destacados. O primeiro é que o universo de alunos atendidos é, em termos reais, expressivamente maior no Brasil: 8,1 milhões (2000), frente aos 2,8 milhões no México (1998/1999) e 1,4 na Argentina (2001). Ainda assim, em termos proporcionais, é o país que oferece a menor cobertura, pois atende a pouco mais de $40 \%$ dos jovens em idade de cursar esse nível de ensino. No México, o sistema consegue atender uma parcela ligeiramente maior, de cerca de 50\%, enquanto na Argentina a cobertura é de aproximadamente $70 \%$. A universalização da cobertura, porém, é um desafio para as autoridades educacionais dos três países, sobretudo porque, ainda que consiga absorver todos os jovens na idade correspondente, é preciso assegurar que eles concluam essa etapa escolar. Os índices de reprovação e especialmente de evasão é muito superior ao esperado. No caso do Brasil há um outro dado grave: é grande a defasagem entre a idade dos alunos e aquela considerada ideal para cursar o Ensino Médio.

Nos três países, a maior parte dos alunos freqüenta escolas públicas: no Brasil esse setor atende quase $80 \%$ dos matriculados, valor semelhante ao verificado no México e maior do que na Argentina, que recebe $70 \%$.

Apenas na Argentina o Ensino Médio é legalmente obrigatório, ainda que no Brasil e no México a obrigatoriedade esteja posta como uma meta. Nos três países ela tem duração mínima de 3 anos, constituindo o período final da escolarização básica, antes do ingresso no nível superior. A idade ideal para cursar é praticamente a mesma: de 15 a 17 anos no Brasil e na Argentina e de 16 a 18 no México.

Outro ponto comum é o fato de que nos três países os professores para lecionar nesse nível de ensino necessitam ter uma formação superior, ainda que em cada um deles isso possa ser feito de modos diferentes. Nem todos eles, porém, de fato cumprem essa exigência. 
Quanto ao Brasil, o traço mais singular é o fato de uma expressiva parcela dos estudantes fazerem cursos noturnos. A carga horária mais reduzida e o perfil sócio-econômico dos alunos, boa parte trabalhadores, são dois componentes decisivos para limitar o seu desempenho escolar.

Para finalizar, devemos destacar um comentário comum a vários pesquisadores, que apontam a percepção geral, por parte dos alunos, sobre o distanciamento entre os conhecimentos difundidos pela escola e o mundo fora dela, razão, inclusive, para muitos abandonarem os estudos. Embora as referências tenham sido feitas de modo genérico, elas levam à formulação de uma questão central para nosso trabalho: em que medida os currículos e, mais especificamente, os livros didáticos de História contribuem para essa visão dos alunos? 


\section{Capítulo II}

\section{REFORMAS EDUCACIONAIS E NOVAS PROPOSTAS CURRICULARES PARA O ENSINO MÉDIO: OS DESAFIOS DA UNIVERSALIZAÇÃO}

O fator humano é fundamental para a atividade econômica, a competitividade e a prosperidade, quer se manifeste sob a forma menos tangível de

flexibilidade, abertura à inovação e cultura da empresa... Os modelos do emprego e os processos de mudança do lugar de trabalho evoluem rapidamente. Em conjunto, essas mutações exercem

um profundo impacto sobre a topografia dos conhecimentos e das competências pertinentes - por conseqüência, sobre a capacidade dos indivíduos, jovens ou mais idosos, homens ou mulheres, para participarem da vida econômica.

Reunion sur Éducation de Qualité pour Tous, OCDE (1992)

Livros didáticos são artefatos que sofrem múltiplas influências e interferências na sua produção e no seu uso. Dentre elas, uma das mais importantes são os planos curriculares, uma vez que os currículos procuram prescrever, de modo mais ou menos detalhado e idealizado, o que deve ser ensinado aos alunos em cada uma das séries, ciclos ou etapas escolares.

Neste capítulo nosso propósito é apresentar os marcos curriculares que orientam os cursos de História no Ensino Médio na Argentina, no Brasil e no México, antecedidos por considerações sobre as principais linhas pedagógicas que informaram uma "onda de reformas curriculares" havida nos anos 1990 em várias partes do mundo e que também exerceram forte influência na América Latina. Desse modo, apontamos um outro conjunto de semelhanças e diferenças verificadas nos três países, importantes para a análise de nosso objeto. 


\section{A ONDA REFORMISTA}

Se, historicamente, a academia sempre exerceu influência no sistema escolar, no ensino secundário essa influência foi particularmente grande. Ivor Goodson $^{94}$ explica esse fato, primeiro, porque os sistemas de avaliação normalmente eram fixados por ela; segundo, porque o ensino secundário sempre esteve fortemente estruturado nas disciplinas e os programas freqüentemente reproduziam a estrutura científica da disciplina-mãe. Não é de surpreender, então, que nesse nível de ensino as tensões sobre as questões curriculares sejam maiores e, conseqüentemente, as mudanças aí sejam sempre muito mais difíceis $^{95}$. O autor acrescenta ainda um outro fator, que no Brasil parece particularmente relevante: a força dos processos de seleção para ingresso na universidade, que tende a subordinar o ensino secundário a sua lógica. Entretanto, desde os anos 1980 o modelo de ascensão escolar para o nível secundário rompeu com o tradicional paradigma do mérito, ou seja, com uma concepção de que o ensino secundário e, especialmente, o superior deveriam ser exclusivos para aqueles que mostraram méritos e condições intelectuais, "os eleitos", como já foram chamados ${ }^{96}$. Essa concepção de sistema educacional hierarquizado e altamente elitista não atendia mais à realidade social, em processo de transformação, que passava a exigir a universalização do ensino secundário. Esse nível escolar era acusado de acentuar as desigualdades sociais, de ser pouco aberto ao mundo exterior, não preparar os jovens nem para os cursos superiores nem para o trabalho, apresentar pouca pertinência com relação às matérias ensinadas e pouca preocupação com a aquisição de atitudes e valores $^{97}$. Assim, no final dos anos 1980, ganhou impulso uma visão educacional que desde o início dos anos 1970 já era apregoada pela UNESCO: conceber a educação como um processo contínuo, que se dá também fora da escola e depois dela, de modo que o aprender a conhecer seja a principal meta escolar. Assim, a escola deveria associar uma ampla formação geral com o domínio mais profundo de apenas algumas áreas. Esses conhecimentos, segundo Jacques Delors,

\footnotetext{
94 Goodson, Ivor. A construção social do currículo. Lisboa: EDUCA, 1997.

95 Jacques Delors chega mesmo a indagar: "será o caso de afirmar que esse ensino secundário é de algum modo 'o mal amado' de toda a reflexão sobre a educação?". Delors, Jacques. Educação: um tesouro a descobrir. São Paulo: Cortez; Brasília: UNESCO, 2003, p. 23.

96 Goodson, I. Op. Cit. p. 83.

${ }^{97}$ Delors, J. Op. Cit. p. 134.
} 
serviriam de "passaporte para uma educação permanente, na medida em que fornece o gosto e as bases para a aprendizagem ao longo de toda a vida""98.

Assim, desde essa época, em diversos países europeus verificou-se um conjunto de ações governamentais no sentido de universalizar a educação secundária. Embora o percentual de cobertura já fosse relativamente alto, era preciso atender a uma parcela social que ainda saía do sistema educacional ao final da Educação Básica, por volta dos 14 anos. O desafio era duplo: massificar, sem perder a qualidade, ao mesmo tempo em que era preciso oferecer capacitação profissional àqueles que não pretendiam ingressar em um curso superior.

$\mathrm{Na}$ Inglaterra, a reforma do sistema educativo promovida em 1988, foi bastante profunda, atingindo os vários estágios da escolarização; já na França, as mudanças atingiram mais diretamente o nível médio (baccalauréat), de modo que se chegasse no ano 2000 com uma cobertura de $80 \%$ de atendimento. $\mathrm{Na}$ Espanha as reformas começaram em 1990, tendo estabelecido a obrigatoriedade e a gratuidade da educação até os 16 anos, criando para tanto um novo curso secundário, destinado aos jovens entre 12 e 16 anos. Nesse país o esforço para a descentralização do sistema foi muito importante e serviu de inspiração, quando não de modelo, para diversos outros ${ }^{99}$.

Essas reformas foram acompanhadas por um processo de intensificação de avaliações nacionais ou mesmo envolvendo diversos países, como aquelas promovidas pela OCDE (Organização de Cooperação para o Desenvolvimento Econômico). O objetivo de tais avaliações era estabelecer marcos comparativos de desempenho dos alunos e dos sistemas educacionais, mesmo reconhecendo as inevitáveis limitações que tais instrumentos teriam. Assim, França, Inglaterra, Espanha e País de Gales começaram a realizar exames ao final da educação secundária. Na Inglaterra, a esse exame se somou um outro sistema avaliativo, denominado de "efeito escola", em que as autoridades educativas procuravam verificar o "valor agregado" da educação ao longo das etapas escolares. Algo semelhante também começou a ser feito com estudantes franceses, que

98 Idem, p. 20

99 Cf. Castanón, Roberto y Seco, Rosa. La Educación Media superior en México: una invitación a la reflexión. México: Noriega, 2000. p.45. Dados da Unesco, publicados no Word education report, em 1995, davam conta que nos países desenvolvidos a taxa de atendimento atingira cerca de 90\%. Cf. Diretrizes Curriculares Nacionais para o Ensino Médio. In: Parâmetros curriculares Nacionais para o Ensino Médio. Brasília: MEC, 2002, p. 66. 
passaram a se submeter a exames na $2^{a}$ série do curso elementar (aos 8 anos), no Sexième (aos 11 anos) e na passagem do collége para o lycée, por volta 14 ou 15 anos $^{100}$.

Não foi apenas na Europa que se viram movimentos reformistas. Antes, em 1985, preocupados com o desempenho de seus alunos nas áreas de Ciências e Tecnologia, a Associação Norte-americana para o Avanço da Ciência (AAAS) desenvolveu o "Projeto 2061" (alusão ao ano do "retorno" do Cometa Halley à Terra), cujo objetivo principal era promover reformas curriculares que ampliassem os conhecimentos dos alunos nessa área, melhorando seu raciocínio lógico e crítico. Desse modo se procurava combater o que chamaram de analfabetismo científico, que colocava os estudantes norte-americanos em franca defasagem com estudantes europeus e, sobretudo, asiáticos ${ }^{101}$.

A onda reformista na educação ganhou ainda maior impulso e amplitude geográfica depois da Conferência Mundial de Jomtien, na Tailândia, em 1990. Autoridades, especialistas e organizações não-governamentais de 155 países, além de 20 organismos intergovernamentais, lançaram um documento - a Declaração Mundial sobre Educação Para Todos: plano de ação para satisfazer as necessidades básicas de aprendizagem - com metas visando aumentar a eqüidade educacional, sobretudo nos países em desenvolvimento. No artigo 4 desse documento, aborda-se um dos pontos centrais da proposta: o foco na aprendizagem:

100 Ibidem e Perrenoud, Phillipe. Construir as competências desde a escola. Porto Alegre: Artmed, 1999, p.18.

101 Idem p. 46-47. Vale a pena mencionar que em julho de 2005 foi publicado nos Estados Unidos, pela Harvard Graduate School of Education o livro Os alunos que abandonam a escola nos EUA: Confrontando a crise do índice de graduação, obra constituída por uma coletânea de ensaios em que os autores chamavam a atenção para o fato de que apenas $2 / 3$ dos alunos americanos concluíam o Ensino Médio, sendo que entre os negros, latinos e índios esse percentual caíra para 1/2. A Gates Fundation, financiada por Bill e Melinda Gates, publicou na mesma época um estudo demonstrando como a conclusão desse nível de ensino representava melhorias salariais expressivas, sem contar que entre eles era menor o índice de desemprego, de presos e de eleitores absenteístas. O articulista da revista The New Yorker que comentava esse estudo, chamava atenção para os riscos que isso representava para o futuro do país. Cf. O Estado de São Paulo, 24 de julho de 2005, p. A26. Algumas semanas antes, o mesmo jornal paulista trazia um artigo assinado pelo próprio Bill Gates, publicado originalmente no jornal Los Angeles Tmes, em que ele usa adjetivos como obsoletas, falidas, defeituosa e desprovidas dos recursos necessários para caracterizar as high schools de seu país. Projetadas em outra época, as escolas não ensinam o que as crianças precisam saber, arruinando o futuro delas e, por extensão, do país, asseverava o maior bilionário do planeta. Ele se alarmava especialmente com as diferenças curriculares (em que os ricos aprendem álgebra, enquanto os pobres fazem exercícios para aprender tirar o saldo em um talão de cheques) e os elevados índices de evasão nesse nível escolar, entre os mais altos do mundo. Cf. O Estado de São Paulo, 6 de março de 2005, p. A24. 
A tradução das oportunidades ampliadas de educação em desenvolvimento efetivo - para o indivíduo ou para a sociedade dependerá em última instância de, em razão dessas mesmas oportunidades, as pessoas aprenderem de fato, ou seja, aprenderem conhecimentos úteis, habilidades de raciocínio, aptidões e valores [...].

No final do artigo, associava-se o alcance dessa meta à criação e implementação de sistemas de avaliação de desempenho dos alunos ${ }^{102}$.

No caso da América Latina, as reformas tinham como primeira meta universalizar a Educação Fundamental, mas havia também preocupação de ampliar o atendimento no ensino secundário, onde já começava haver maior demanda, de modo que os egressos do ensino fundamental pudessem seguir seus estudos.

Diversos autores vêem estreita ligação entre esse evento e a implementação de reformas em vários países da América Latina, sobretudo porque a Conferência de Jomtien foi promovida pelo Programa das Nações Unidas para o Desenvolvimento (PNUD), pela UNESCO, UNICEF e pelo Banco Mundial (BIRD), organismos que apoiariam, tanto financeira como tecnicamente, as reformas educacionais efetuadas nos anos seguintes em muitos países. Mais ainda, esses autores não acham que seja mera coincidência o fato de tais reformas ocorrerem simultaneamente aos programas de "ajustes estruturais", orientados pelo FMI, visando sanear as finanças públicas dos países latino-americanos, bastante comprometidas pelos endividamentos interno e externo, e pelos déficits públicos crônicos. As reformas educacionais seriam, segundo essa ótica, um dos braços dos organismos internacionais para aprofundar a implantação do modelo neoliberal nesses países ${ }^{103}$.

102 Declaração Mundial sobre Educação Para Todos. Plano de ação para satisfazer as necessidades básicas em aprendizagem. Brasília: UNICEF, 1990.

103 São exemplos dessa visão: Bueno, Maria Sylvia S. Políticas atuais para o ensino médio. Campinas: Papirus, 2000; Zibas, D., Aguiar, M. e Bueno, M.S.S. O Ensino Médio e a reforma da Educação Básica. Brasília: Plano, 2002. Há de se registrar uma outra coincidência: a implantação das "reformas estruturais" provocou elevação no índice de desemprego e, desse modo, muitos jovens tiveram de postergar a sua entrada no mercado de trabalho, o que servia como um estímulo a mais para continuarem seus estudos, de modo a ampliar suas oportunidades futuras. Como se vê, o crescimento da procura por vagas no ensino médio teve várias motivações. 
Entretanto, como observa Martin Carnoy, ${ }^{104}$ ele mesmo um assessor do BIRD, as reformas educacionais com objetivo de ampliar a equidade social tendem a ser contrárias às reformas financeiras, uma vez que elas aumentam os dispêndios governamentais com educação. Além disso, os organismos internacionais sugerem que esses recursos sejam aplicados preferencialmente na Educação Básica, em detrimento da Educação Secundária e, sobretudo, da Superior, uma vez que o financiamento às instituições públicas desses dois níveis tenderia a beneficiar aqueles estratos sociais que conseguiram ultrapassar todas as barreiras do sistema, chegando a uma universidade; seriam, portanto, segmentos privilegiados. Seria preferível, segundo a ótica dessas entidades, deixar esses níveis de ensino a cargo das instituições privadas. Na Educação Básica, ao contrário, a relação custo/benefício seria muito mais alta; logo, seria mais compensador economicamente concentrar aí os investimentos públicos. As orientações, observa Carnoy, não parecem ter se convertido em ação ${ }^{105}$.

Outro aspecto destacado por Carnoy parece igualmente pertinente aos países em tela: o processo de descentralização do sistema. Segundo ele, as reformas ocorridas na Argentina em 1978 e 1993, no México em 1991 e no Brasil em 1996 apontam claramente para uma maior autonomia dos governos estaduais ou provinciais, e mesmo das escolas, na definição de seus planos pedagógicos. Foram feitas transferências de gestão e responsabilidade financeira tanto para as províncias ou estados como para os municípios, de tal sorte que coubesse a essas esferas administrativas parcela importante dos gastos com educação. Ocorre que nem sempre esses encargos vieram acompanhados com os aportes

104 Carnoy, Martin. Mundialização e Reforma na Educação. Brasília: UNESCO/IIPE, 2003.

105 De fato, essas teses não parecem caber para os casos do México, da Argentina e do Brasil, uma vez que nos três países é muito expressivo o número de alunos atendidos pelo sistema público, tendo havido ainda um forte crescimento nos últimos anos, como apontamos no capítulo anterior. Autores como Luiz Antonio Cunha consideram totalmente equivocadas as interpretações filiadas a "teorias conspiratórias", segundo as quais os organismos internacionais, como o BIRD, seriam meros agentes dos países centrais, defendendo seus interesses. É preciso lembrar que assessores e especialistas brasileiros, mexicanos e argentinos (e de outros países) integram esses organismos, compondo as comissões técnicas que assessoram os governos nacionais. Portanto, muitas vezes são pesquisadores nacionais (ou latino-americanos), que fornecem diretrizes para as reformas, defendendo pontos de vista que eram seus antes de ingressar nesses organismos. O autor dá como exemplo o pesquisador Cláudio Moura e Castro, que desempenhou papel relevante durante a gestão de Paulo Renato frente ao MEC, e que como técnico do Banco Mundial apenas implementou o que ele defendia, muito tempo antes, no tocante ao ensino médio. Assim, segundo Cunha, mais do que uma "lógica" do capital internacional, deveria se privilegiar mais uma análise sociológica entre esses técnicos, suas idéias e sua trajetória profissional. Cunha, Luiz Antonio. "As agências financeiras internacionais e a reforma brasileira do Ensino Técnico: a crítica da crítica". In: Zibas, D., Aguiar, M. e Bueno, M.S.S. Op. cit. p. 103-132. 
financeiros devidos, resultando em escassez de recursos e limitações estruturais para implementação das reformas. Mais ainda: em uma conjuntura mundial muito instável, os países passaram por momentos de aguda crise, que, entre outras graves conseqüências, diminuiu drasticamente o poder de ação dos governos, dada as limitações financeiras que enfrentavam. Portanto, no momento mesmo em que esses países se esforçavam para ampliar a escolarização da sua população, os investimentos públicos precisaram ser cortados, afetando a área educacional (salários de professores, equipamentos, instalações, etc.) geralmente responsável por parcela expressiva dos orçamentos públicos. O resultado em toda a América Latina foi uma queda acentuada na qualidade de ensino, ainda mais visível com os sistemas de avaliação implantados, acompanhada de problemas tradicionais, como a evasão e a repetência ${ }^{106}$.

\section{AS REFORMAS PARA O ENSINO MÉDIO}

No caso específico do Ensino Médio, as reformas realizadas no México, na Argentina e no Brasil procuraram resolver um problema crônico desse nível de ensino: sua falta de identidade.

As novas realidades do mundo do trabalho - que parecem tornar cada vez menos provável que um jovem ingresse no mercado formal desempenhando uma certa função e nela permaneça ao longo da sua vida produtiva - passaram a exigir uma educação diferente, tanto no tocante ao ensino profissionalizante como no tradicional modelo propedêutico, preparatório para o ensino superior, que durante décadas predominou nesse nível escolar (e que conferia ao ensino médio o caráter de mera etapa intermediária na formação escolar). É generalizada hoje em dia a convicção de que mesmo os alunos que pretendem continuar seus estudos, ingressando em uma universidade, precisam adquirir, no lugar do rol de

106 Bueno, Maria Sylvia. Políticas públicas para o Ensino Médio. Campinas: Papirus, 2000. p. 89. Com relação à reforma na Argentina ver Ziegler, Sandra. De las políticas curriculares a las resignificaciones de los docentes: una análisis de la reforma de los años '90 en la Provincia de Buenos Aires a partir de la recepción de documentos curriculares por parte de los docentes. Flacso, 2001, tesis de doctoramento. A autora vê na tentativa de descentralização promovida pela Ley Federal de Educación alguns avanços, mas também reconhece a força da tradição centralizadora, que marca a educação em seu país, o que resultou, na implementação das reformas, diversos embates entre os três níveis educacionais ( federal, provincial e o das próprias escolas). 
conhecimentos tradicionais desse nível escolar, um conjunto de competências básicas e fundamentais para a vida.

Esse termo assumiu, no contexto das reformas, um papel central em todos os discursos educacionais dos três países. Às competências associa-se freqüentemente a idéia de desenvolvimento de habilidades. Assim, o foco deixou de ser os conteúdos disciplinares clássicos para se valorizar a resolução de problemas, o raciocínio lógico, a compreensão leitora, o domínio de procedimentos metodológicos (habilidades procedimentais), e a valorização do comportamento colaborativo (habilidades atitudinais). Todas as questões de aprendizagem ganharam maior atenção, sendo abordados em uma vasta bibliografia, em que se sobressaem os trabalhos de psicólogos e psicopedagogos. As novas máximas educacionais asseveravam que, tão importante quanto saber, é saber fazer, e, sobretudo, aprender a aprender ${ }^{107}$, de modo que o aluno desenvolvesse autonomia para continuar adquirindo novos conhecimentos, mesmo depois de finalizada sua escolarização básica. Só assim ele poderia enfrentar as novas demandas do mercado de trabalho, que exigem profissionais mais flexíveis, com grande criatividade e facilidade para o trabalho em equipe ${ }^{108}$.

A educação para o trabalho, portanto, ganha uma enorme ênfase. Mas é preciso realçar um aspecto importante: educação para o trabalho não mais se confunde com profissionalização e menos ainda com ensino técnico. Toma-se como novo paradigma que educar para a cidadania e para o trabalho é uma tarefa só, una. Qualquer educação é educação para o trabalho, entendendo-se por trabalho algo mais amplo. Os antigos modelos de adestramento técnico não mais atendem ao mercado de trabalho, o que explica o fracasso de muitas iniciativas de

107 A difusão dessas máximas teve no documento produzido pela Comissão Internacional de Educação para o Século XXI, dirigida Jacques Delors, denominado Educação: um tesouro a descobrir, um grande motor. Neles foram fixados como os 4 pilares da educação o aprender a aprender e conhecer; aprender a ser, aprender a fazer e aprender a viver com os demais. Delors. J. Op. cit.

Martin Carnoy argumenta que dentre os múltiplos impactos que a mundialização tem provocado, aqueles relacionados ao mundo da educação e do trabalho são especialmente fortes. Mesmo trabalhadores com alta capacitação tendem a não ter uma carreira profissional tradicional, com emprego permanente em uma só empresa. Deverá prevalecer o trabalho temporário (mesmo que contínuo), ligado a diferentes projetos, que provavelmente farão com que o trabalhador tenha uma rede de colegas, com quem se comunica pela internet, mas com quem tem pouco contato pessoal. Será, segundo o autor, inevitável a necessidade de constante aperfeiçoamento, exigindo grande adaptabilidade e formação educacional de alta qualidade, que dê autonomia para o indivíduo coletar e interpretar informações, enfrentar desafios, resolver problemas. Carnoy. M. Op. cit, pp 35- 51 (Capítulo 2). 
promover cursos secundários profissionalizantes. O desenvolvimento das capacidades intelectuais dos alunos passa a ser fundamental. Nesse sentido, falase em uma oportunidade histórica de superação do velho e aparentemente insolúvel problema da dicotomia entre educação para a vida/estudos e educação para o trabalho, valorizando-se mais a formação humana ${ }^{109}$. É preciso realçar que essa visão é menos tributária de uma revalorização dos estudos humanistas clássicos e mais resultado de uma constatação contundente: a revolução tecnológica, acentuada a partir dos anos 1980, acelerou de tal modo a velocidade das inovações nesse campo que a escola, por mais que procurasse se manter atualizada na formação de seus estudantes, nunca conseguiria uma sincronia entre a formação deles e as necessidades do mercado. A percepção de uma defasagem inexorável e crônica entre os conhecimentos que os alunos egressos dos cursos técnicos disporiam e as necessidades do mercado de trabalho geraram tensões e insatisfações generalizadas: pais, alunos, professores, diretores, empresários, autoridades governamentais consideravam o sistema educativo profissionalizante insatisfatório, caro, frustrante. No entanto, o mercado precisa de trabalhadores cada vez mais preparados e a escola precisa dar conta dessa demanda. O que fazer?

O caminho que se tem seguido é o que aponta a necessidade de conferir aos estudantes capacitação para que eles próprios promovam, continuamente, sua auto-atualização. Ou seja, a principal atribuição da escola passa a ser desenvolver as competências básicas para que os estudantes continuem a adquirir novos conhecimentos de maneira autônoma, para o resto de suas vidas. Com isso desloca-se o foco dos currículos do domínio de um amplo leque de repertório informativo para um conjunto de competências e habilidades que os alunos devem demonstrar ao final de cada etapa escolar, particularmente no ensino médio. Desse modo, as aprendizagens, mais do que os conteúdos propriamente, passam a ser o centro das propostas curriculares. Essa perspectiva oferece ainda outra vantagem, pois aponta uma saída para outro impasse muito evidente nesse nível de ensino: o crescente acúmulo de informação agregado aos currículos de cada uma das disciplinas, resultante do próprio avanço nas várias ciências de referência que as informam ou de novas abordagens dadas a elas. Os cursos de caráter enciclopédico perdem força e passa-se a valorizar a capacidade 
do aluno buscar, nos mais diversos meios que as tecnologias da informação disponibilizam, a informação de que necessita para dar conta de responder a uma dúvida, um problema, uma indagação. Disso decorre, por exemplo, uma mudança de paradigma na formulação das avaliações, do qual o Exame Nacional do Ensino Médio (ENEM), no caso brasileiro, é um bom exemplo. Esse enfoque educacional, acredita-se, tem forte papel na formação para o trabalho, pois se desenvolve em torno de projetos em equipes, e consegue romper com os modelos tradicionais de disciplinas estanques, proporcionando oportunidades de estudos ou abordagens interdisciplinares.

É interessante observar que a origem da concepção da aprendizagem por competência foi a França socialista de F. Mitterrand, onde se procurava assegurar aos alunos mais pobres a valorização de seus aprendizados e modos de aprender, para evitar a seletividade com base na origem social, já que os alunos de estratos superiores tinham um repertório cultural superior e avaliações com foco em domínio de conteúdos tendiam a privilegia-los ${ }^{110}$. Assim, o primeiro âmbito educacional em que a idéia de competência circulou foi da educação profissional, transbordando, logo depois, para as outras modalidades.

Mas essas concepções têm seus críticos ${ }^{111}$. Considerando a questão dos investimentos como algo fundamental para os países em desenvolvimento superarem seus problemas sociais, ampliando a atividade econômica e a renda da população, e tendo em vista a nova lógica que rege o mundo do trabalho, muitos concluíram que apenas mercados que possuam trabalhadores qualificados poderão se habilitar a disputar e receber uma expressiva parcela dos investimentos internacionais. Disso decorre, segundo alguns autores, uma valorização dos modelos educacionais que privilegiam a racionalidade e a eficiência, sendo a noção de competência a expressão por excelência desse modelo. Ainda que a abordagem por competências tenda a valorizar o trabalho coletivo, os procedimentos na elaboração das tarefas, bem como as atitudes dos alunos (o que pressupõe a adoção de valores sociais como o respeito e a cooperação), os modelos educacionais assentados nesses princípios, afirmam

110 Cf. Kuenzer, Acácia. Ensino Médio: construindo uma proposta para os que vivem do trabalho. São Paulo: Cortez, 2002.

111 Os artigos que compõem o livro $O$ enigma da competência em educação podem servir de exemplo dessas críticas. Dolz, Joaquim e Ollagnier, Edmée. O enigma da competência em educação. Porto Alegre: Artmed,2004. 
esses autores, acabam por privilegiar o desempenho individual dos alunos, por meio de medidas de avaliação objetivas, geralmente aferidas dentro de um grande universo de alunos.

Uma outra crítica comum a esse modelo por competências é que ele tende a esvaziar a importância dos conteúdos. A interpretação de um texto ou de um enunciado passa a ser mais relevante do que o domínio ou reflexão sobre um dado tema. As informações, assim, podem se tornar apenas meios para se aferir a capacidade leitora do indivíduo ${ }^{112}$.

Philippe Perrenoud, um dos mais importante teóricos e defensores da aprendizagem por competências, argumenta, rebatendo as críticas, que o desenvolvimento de competências não implica desconsiderar a aquisição de conhecimentos, uma vez que competência é "uma capacidade de agir eficazmente em determinado tipo de situação apoiada em conhecimentos, mas sem limitar-se a eles"113. Competências e conhecimentos estão, pois, sempre associados, de modo complementar. Contudo, em termos de escolaridade, pode haver "conflitos de prioridades", ou seja, considerando que a escolaridade como um todo, e a aula de modo particular, têm um tempo determinado para transcorrer, o que acaba se impondo é uma escolha: "cabeças bem-feitas $x$ cabeças bem-cheias" ${ }^{114}$ É precisamente dessa escolha, ou a busca de um equilíbrio entre esses dois modelos, que resultará o perfil dos currículos, ficando mais comprometidos com o desenvolvimento das competências ou mais vinculados a uma educação de caráter enciclopédico. Depreende-se, por esses argumentos, que a articulação entre as disciplinas e a abordagem por competências é bastante difícil, pois ambas são orientadas por princípios distintos. A primeira é, em geral, orientada por uma lógica interna, enquanto a segunda

112 Luis Fernando Cerri, discutindo a questão dos saberes históricos nas provas do Exame Nacional do Ensino Médio (ENEM), exemplifica esse problema no âmbito do ensino de história, ao mostrar como há um predomínio de questões em que os conteúdos históricos são meros recursos para se aferir o quanto o aluno é capaz de entender o que lê. Cerri, Luis Fernando. "Saberes históricos diante da avaliação do ensino: notas sobre os conteúdos de história nas provas do Exame Nacional do Ensino Médio ENEM". Revista Brasileira de História, n. 48, vol. 24, 2005, p. 213- 231.

113 Perrenoud, Philippe. Construir competências desde a escola. Porto Alegre: ArtMed, 1999, p. 7.

114 A propósito dessa questão posta desde os tempos de Montaigne, o famoso pensador francês Edgar Morin foi convidado pelo Ministério da Educação de seu país a colaborar na reforma do Ensino Médio, daí resultando um conjunto de oito jornadas conduzidas por ele. A conclusão mais contundente desses debates foi que sem uma reforma no pensamento, que privilegiasse a compreensão do todo e não das partes, pouco se avançaria. Ver Morin, Edgar. A cabeça bem feita - repensar a reforma, reformar o pensamento. Rio de Janeiro: Bertrand Brasil, 2001. 
estaria vinculada a uma compreensão do, e a uma ação no, mundo. Essa segunda abordagem seria muito mais abrangente, uma vez que não se liga a apenas a uma determinada área de conhecimento, assumindo caráter mais transversal. Daí porque é tarefa complexa "converter" as disciplinas clássicas em programas escolares voltados para as competências, sobretudo porque essas necessariamente exigem contextualização e formulação de problemas práticos e significativos para os alunos, considerando, pois, a sua realidade social e cultural, o que colide com concepções curriculares em que o estudo dos conteúdos se justifica por si mesmo ${ }^{115}$.

Retomando a questão da educação no novo cenário mundial, torna-se corrente a crença de que para ser atraente e competitivo, um país precisa oferecer trabalhadores com esse novo perfil de domínio de competências. Por outro lado, o país precisa dispor de mecanismos que garantam baixos salários. No caso dos três países da América Latina que analisamos, esse cenário levou os governos a decidir por políticas educacionais nacionais visando aumentar o tempo de escolarização e melhorar a qualidade de educação oferecida para um grande contingente de jovens, de modo que esses tivessem a possibilidade (mas não a garantia) de inserção no novo mercado de trabalho. E para alcançar tais fins, foi preciso otimizar os investimentos. Uma das recomendações dos organismos internacionais que orientavam a implementação de tais políticas era a de que as classes fossem numerosas, com cerca de 45 alunos, aumentando assim a relação número de alunos por professor; outra recomendação é que os professores passassem a ser mais valorizados ${ }^{116}$ e que lhes fossem oferecidos cursos de capacitação continuada, objetivando aumentar a qualidade das aulas; e fossem ainda empregados recursos de alto rendimento e baixos custos, fazendo uso especialmente das novas tecnologias da comunicação. Contudo, os organismos internacionais continuaram vendo os livros didáticos como o melhor recurso na relação custo/benefício para se promover a melhoria nos níveis de educação, uma

115 Idem, ver especialmente Cap. 2 - Programas escolares e competências.

116 Segundo a OCDE, "os elementos complexos de atratividade da profissão docente não se restringem apenas aos salários, mas também ao julgamento social que se faz do seu trabalho, o isolamento parcial que experimentam em seu trabalho e o grau de profissionalismo que lhes é reconhecido pela burocracia da educação. Reunion sur Éducation de Qualité pour tous. OCDE, 2002, apud Carnoy, Op. Cit. P. 59-60. 
vez que por meio deles é possível requalificar os professores, fornecendo encartes com diversos tipos de orientações ${ }^{117}$.

\section{BRASIL : OS PARÂMETROS CURRICULARES NACIONAIS PARA O ENSINO MÉDIO}

Procuramos desenhar até aqui as novas balizas educacionais formuladas entre os anos 1980 e 1990 que orientaram as reformas educacionais como um todo. No caso específico do Brasil, essa reformulação, no tocante aos currículos, expressou-se por meio dos Parâmetros Curriculares Nacionais (PCNs), que foram organizados em três módulos: dois para o Ensino Fundamental (um para os dois primeiros ciclos e outro para os dois finais, cobrindo os oito anos dessa etapa escolar) e um para o Ensino Médio. Esses documentos derivaram das disposições da Lei de Diretrizes e Bases (LDB), aprovada em 1996. Os PCNs do Ensino Médio foram aprovados junto com as Diretrizes Curriculares Nacionais para o Ensino Médio (DCNEM), em 1998, sendo que o primeiro documento têm caráter mais orientador e o segundo mais impositivo ${ }^{118}$. Em ambos os textos são evidentes os vínculos com as premissas definidas pela UNESCO nos documentos anteriormente referidos. Aprender a conhecer, aprender a fazer, aprender a viver e aprender a ser são definidos explicitamente como os eixos estruturais da educação nacional, o que claramente indica um privilegiamento do âmbito da aprendizagem frente ao domínio de rol de conteúdos informativos mínimos ou básicos. Como conseqüência, os PCNs assumem um discurso muito mais voltado para o como ensinar do que para o quê ensinar: "não se trata mais de acumular conhecimentos" afirma-se ${ }^{119}$. Pode-se dizer que o conhecimento a ser ensinado é exatamente o como fazer para adquirir os conhecimentos de que se necessita para a vida e para o trabalho (o aprender a aprender). Daí porque, ao definir o papel da educação em uma sociedade tecnológica, se afirma a necessidade do

117 Idem p. 64. Um bom exemplo dessa visão encontramos nos programas brasileiros de distribuição de livros didáticos, os PNLDs. Nos processos de avaliação das obras que poderão ser selecionadas pelos professores, um dos critérios importantes é exatamente o chamado Manual do Professor, que deve conter diversas modalidades de orientações, tanto no âmbito pedagógico como das áreas de conhecimento abarcadas pela disciplina.

118 "Estas DCNEM não pretendem, portanto, ser as últimas, porque no âmbito pedagógico nada encerra toda a verdade, tudo comporta e exige contínua atualização. Enquanto expressão das diretrizes e bases da educação nacional, serão obrigatórias uma vez aprovadas e homologadas." Diretrizes Curriculares Nacionais para o Ensino Médio - Parecer CEB 15/98. In: PCNs do Ensino Médio. Brasília: MEC, 2002, p. 64.

119 O novo Ensino Médio. PCNs do Ensino Médio. Brasília: MEC, 2002, p 15. 
desenvolvimento das competências para o exercício da cidadania e do desempenho profissional. E diz textualmente o documento:

De que competências se está falando? "Da capacidade de abstração, do desenvolvimento do pensamento sistêmico, ao contrário da compreensão parcial e fragmentada dos fenômenos, da criatividade, da capacidade de pensar múltiplas alternativas para a solução de um problema, ou seja, do desenvolvimento do pensamento crítico, da capacidade de trabalhar em equipe, da disposição para procurar e aceitar críticas, da disposição para o risco, do saber comunicar-se, da capacidade de buscar conhecimento"120.

Em linha com esses princípios, as DCNEM estabelecem que:

Esses conhecimentos e competências é que dão sustentação à análises, à prospecção e à solução de problemas, à capacidade de tomar decisões, à adaptabilidade a situações novas, à arte de dar sentido a um mundo em mutação.

Não é por acaso que essas mesmas competências estão entre as mais valorizadas pelas novas formas de produção pós-industrial que se instalam nas economias contemporâneas. Essa é a esperança e a promessa que o novo humanismo traz para a educação, em especial a média: a possibilidade de integrar a formação para o trabalho num projeto mais ambicioso de desenvolvimento da pessoa humana ${ }^{121}$.

Tomaz Tadeu da Silva afirma que "o currículo é sempre o resultado de uma seleção: dentro de um universo mais amplo de conhecimentos e saberes, seleciona-se aquela parte que vai constituir, precisamente, o currículo. As teorias do currículo, tendo decidido quais conhecimentos devem ser selecionados, buscam justificar porque 'esses conhecimentos' e não 'aqueles' devem ser

120 "O papel da educação na sociedade tecnológica". PCNs do Ensino Médio. Brasília: MEC, 2002, p. 23-24. No texto que introduz a proposta da reforma, lê-se: "Essa educação geral, que permite buscar informação, gerar informação, usá-la para solucionar problemas concretos na produção de bens ou na gestão e prestação de serviços, é preparação básica para o trabalho. $\mathrm{Na}$ verdade, qualquer competência requerida no exercício profissional, seja ela psicomotora, socioafetiva ou cognitiva, é um afinamento ds competências básicas. Essa educação geral permite a construção de competências que se manifestarão em habilidades básicas, técnicas ou de gestão". Cf. PCNs, op. Cit. p. 31.

121 Diretrizes Curriculares Nacionais para o Ensino Médio. PCNs do Ensino Médio. Brasília: MEC, 2002, p. 79. 
selecionados"122. Essa seleção não é feita apenas no âmbito dos conhecimentos de uma ou mais ciência que informam uma disciplina. Além desses conteúdos, muitos outros são agregados: os saberes próprios dos professores, tanto aqueles vindos dos diversos campos da pedagogia como os resultantes das práticas escolares, o repertório de conhecimentos consagrados pela tradição escolar, questões de caráter social e cultural próprios de uma sociedade e de uma época. Portanto, o currículo constitui sempre um campo de forças e tensões, sendo necessário ainda considerar que o documento de caráter oficial e prescritivo não se realiza tal e qual na sala de aula. Como adverte Goodson, na fase interativa, em que o currículo é implementado por meio de ações, ele pode ser subvertido ou transcender a fase pré-ativa ${ }^{123}$. No caso dos livros didáticos, objeto que nos interessa de modo mais efetivo, podemos entendê-los como expressões interpretadas e concretizadas - das formulações curriculares oficiais e, assim, um dos mediadores entre o currículo pré-ativo e o currículo interativo. Como veremos mais detidamente no capítulo seguinte, os livros didáticos guardam uma maneira de conceber o conhecimento e uma concepção da disciplina, e formulam uma proposta prática de currículo, o que necessariamente implica na expressão de uma certa concepção de currículo. Com nossa análise poderemos aferir, então, em que medida os livros didáticos foram elaborados em sintonia com as propostas oficiais (de âmbito nacional) curriculares. Em uma perspectiva comparada, será possível verificar um aspecto interessante, apontado por Pierre Bourdieu ${ }^{124}$ quando observou que os currículos e mais especificamente os programas escolares indicam claramente um conjunto de questões ou temas obrigatórios que definem o campo cultural de uma época, ou seja, poderemos identificar como essas orientações curriculares, dentro dos marcos já apresentados, promovem, ou não, um rearranjo dos conteúdos históricos, valorizando tais e quais questões. Dito de maneira mais precisa: em que medida as orientações de um currículo organizado segundo a abordagem de aquisição de competências resulta em uma (nova? diferente?) abordagem para o ensino de história ?

122 Silva, Tomaz Tadeu. Documentos e Identidade: uma introdução às teorias do currículo. Belo Horizonte: Autêntica: 2003, p. 14.

123 Goodson, Ivor. Currículo: teoria e história. Petrópolis: Vozes, 1995, p. 24.

124 Bourdieu, Pierre. "Sistema de ensino e sistema de pensamento". In: A economia das trocas simbólicas. São Paulo: Perspectiva: 1992, p. 207. 
Tomando, então, a proposta desenhada nos PCNs de História para o Ensino Médio, que questões e temas foram privilegiados, considerando toda a moldura definida anteriormente?

Primeiro aspecto a destacar é que a proposta de história integra uma outra, mais ampla, denominada área de Ciências Humanas e suas Tecnologias, em que são contemplados conhecimentos de geografia, sociologia e filosofia, bem como de antropologia, política, direito, economia e psicologia, todos vistos como “indispensáveis à formação básica do cidadão ${ }^{125}$. Ressalte-se que não se defende a disciplinarização desses conhecimentos, de modo que todos eles se tornem componentes curriculares próprios, mas que eles sejam tomados, ao contrário, desde uma perspectiva interdisciplinar e contextualizada, que sempre leve em conta a realidade e as experiências dos alunos. Valoriza-se, pois, os conhecimentos humanísticos, articulados com o estudo das ciências, como possibilidade de compreensão do real e visando a construção de uma sociedade mais justa e solidária ${ }^{126}$.

No tocante às competências e habilidades, destaca-se o aprender a conhecer, visto como "base que qualifica o fazer, o conviver e o ser, e síntese de uma educação que prepara o indivíduo e a sociedade para os desafios futuros, em um mundo em constante e acelerada transformação". E prossegue:

Cabe ainda observar preliminarmente que as competências não eliminam os conteúdos, pois que não é possível desenvolvê-las no vazio. Elas apenas norteiam a seleção dos conteúdos, para que o professor tenha presente que o que importa na Educação Básica não é a quantidade de informações, mas a capacidade de lidar com elas, através de processos que impliquem sua apropriação e comunicação, e, principalmente, sua produção ou reconstrução, a fim de que sejam transpostas a situações novas.

Somente quando se dá essa apropriação e transposição de conhecimentos para novas situações é que se pode dizer que houve aprendizado. Do contrário, o que se dá é um simplório mecanismo de memorização, através do qual os fatos, mas não as idéias, circulam de uma folha de papel para outra, do livro didático 
para o caderno e do caderno para a prova, caindo em esquecimento no dia seguinte, por não encontrarem ressonância nem fazerem sentido para quem lê, ouve ou escreve ${ }^{127}$.

Levado para o âmbito específico dos conteúdos de História, tal perspectiva resulta no seguinte quadro de competências e habilidades a serem desenvolvidas durante o Ensino Médio:

\begin{tabular}{|c|c|}
\hline $\begin{array}{l}\text { Representação e } \\
\text { comunicação }\end{array}$ & $\begin{array}{l}\text { - Entender a importância das tecnologias contemporâneas de } \\
\text { comunicação e informação para planejamento, gestão, organização } \\
\text { e fortalecimento do trabalho de equipe. }\end{array}$ \\
\hline $\begin{array}{l}\text { Investigação e } \\
\text { compreensão }\end{array}$ & $\begin{array}{l}\text { - Compreender os elementos os cognitivos, afetivos, sociais e } \\
\text { culturais que constituem a identidade própria e a dos outros. } \\
\text { - Compreender a sociedade, sua gênese e transformação, e os } \\
\text { múltiplos fatores que nela intervêm, como produtos da ação } \\
\text { humana; a si mesmo como agente social; e os processos sociais } \\
\text { como orientadores da dinâmica dos diferentes grupos de } \\
\text { indivíduos. } \\
\text { - Entender os princípios das tecnologias associadas ao } \\
\text { conhecimento do indivíduo, da sociedade e da cultura, entre as } \\
\text { quais as de planejamento, organização, gestão, trabalho de equipe, } \\
\text { e associá-las aos problemas que se propõem resolver. }\end{array}$ \\
\hline $\begin{array}{l}\text { Contextualização } \\
\text { sociocultural }\end{array}$ & $\begin{array}{l}\text { - Compreender o desenvolvimento da sociedade como processo de } \\
\text { ocupação de espaços físicos e as relações da vida humana com a } \\
\text { paisagem, em seus desdobramentos políticos, culturais, } \\
\text { econômicos e humanos. } \\
\text { - Compreender a produção e o papel histórico das instituições } \\
\text { sociais, políticas e econômicas, associando-as às práticas dos } \\
\text { diferentes grupos e atores sociais, aos princípios que regulam a } \\
\text { convivência em sociedade, aos direitos e deveres da cidadania, à } \\
\text { injustiça e à distribuição dos benefícios econômicos. } \\
\text { - Traduzir os conhecimentos sobre a pessoa, a sociedade, a } \\
\text { economia, as práticas sociais e culturais em condutas de } \\
\text { indagação, análise, problematização e protagonismo diante de } \\
\text { situações novas, problemas ou questões da vida pessoal, social, } \\
\text { política, econômica e cultural. } \\
\text { - Entender o impacto das tecnologias associadas às Ciências } \\
\text { Humanas sobre sua vida pessoal, os processos de produção, o } \\
\text { desenvolvimento do conhecimento e a vida social. } \\
\text { - Aplicar as tecnologias das Ciências Humanas e Sociais na escola, } \\
\text { no trabalho e em outros contextos relevantes para a sua vida. }\end{array}$ \\
\hline
\end{tabular}

Fonte: Parâmetros Curriculares Nacionais. Op. cit. p. 297.

Observe-se que não se menciona um rol de conteúdos mínimos, nem mesmo temas que pudessem constituir um guia para a formulação de um programa. Tampouco há referências aos recortes cronológicos que devam orientar o trabalho dos professores. No texto em que se justifica essa seleção de competências e habilidades argumenta-se que a compreensão da cidadania em uma perspectiva 
histórica pode servir "como referência para a organização dos conteúdos da disciplina histórica"128, por meio de conteúdos significativos (grifo no original) para a atual geração, de onde se pode depreender que a temática poderia ser tomada desde a Antiguidade Clássica. Contudo, o texto assegura que "identificar e selecionar conteúdos significativos são tarefas fundamentais dos professores, uma vez que se constata a evidência de que é impossível estudar 'toda a história da humanidade' "129. Menciona-se explicitamente, em outra parte, que deve ser dada maior ênfase à história nacional, em conformidade com as disposições da $\mathrm{LDB}^{130}$. Porém, não são indicados temas ou assuntos que devam necessariamente ser abordados, tampouco se destaca regiões do mundo cujas sociedades devam merecer especial atenção, como por exemplo a África ou a América Latina. Fala-se, quando muito, que a escravidão pode ser uma temática adequada para se trabalhar a categoria temporal de duração, desde uma perspectiva braudeliana (acontecimento breve, conjuntura e estrutura).

Um documento posteriormente publicado pelo MEC, denominado PCNs+ Ciências Humanas e suas Tecnologias, apresenta quatro sugestões de como converter essas orientações em uma proposta pedagógica com conceitos mais estruturados, organizados a partir de eixos temáticos. A título de exemplo, apresentamos dois desses eixos temáticos sugeridos:

\begin{tabular}{|c|c|}
\hline \multicolumn{2}{|c|}{ EIXOS TEMÁTICOS } \\
\hline CIDADANIA: DIFERENÇAS E DESIGUALDADES \\
\hline Temas & \multicolumn{1}{c|}{ Subtemas } \\
\hline \multirow{3}{*}{ 1. O cidadão e o Estado } & - A definição da cidadania \\
& Cidadania ateniense \\
& Cidadania do século XVIII: Revolução Francesa \\
& - Participação política \\
& Atenas: participação direta dos iguais \\
& Brasil republicano: participação indireta dos desiguais \\
\hline & - A luta pela liberdade \\
& Rebelião de escravos em Roma antiga \\
& Rebeliões e resistência de escravos no Brasil do século \\
& XIX \\
& - Liberdade para lutar \\
& Movimentos negros nos EUA: a luta pelos direitos civis \\
& Movimentos negros no Brasil: contra a discriminação, \\
& por trabalho e educação \\
\hline
\end{tabular}

128 Conhecimentos de história. PCNs do Ensino Médio, Op. cit. p. 305.

129 Idem ibidem.

130 É curioso notar que essa recomendação não está na parte específica de História, mas naquela que trata das competências e habilidades próprias da área. PCNs do Ensino Médio, Op. cit. p.290. 


\begin{tabular}{|c|c|}
\hline 3. Cidadania e etnia & $\begin{array}{l}\text { - Luta por autonomia } \\
\text { Estratégias terroristas: ETA e IRA } \\
\text { Estratégias de guerra: Guerra da luguslávia e/ou } \\
\text { guerras étnicas no continente africano } \\
\text { - Direito de expressão } \\
\text { Movimentos da música étnica } \\
\text { O direito à beleza: arte e moda étnicas }\end{array}$ \\
\hline 4. O cidadão e o Planeta & $\begin{array}{l}\text { - Declaração Universal dos Direitos Humanos } \\
\text { Igualdade entre os sexos } \\
\text { Os direitos da infância, da juventude e da velhice } \\
\text { - Patrimônio da humanidade: o passado e o futuro } \\
\text { Movimentos de consciência ecológica }\end{array}$ \\
\hline \multicolumn{2}{|c|}{ CULTURA E TRABALHO } \\
\hline Temas & Subtemas \\
\hline $\begin{array}{l}\text { 1. Tecnologias e fontes de } \\
\text { energia }\end{array}$ & $\begin{array}{l}\text { - Pedra, madeira e água } \\
\text { Caçadores e coletores na África contemporânea } \\
\text { Revolução agrícola no Oriente Médio } \\
\text { - Máquinas, fogo e eletricidade } \\
\text { Revolução Industrial na Inglaterra (séculos XVIII e XIX) } \\
\text { Revolução tecnplógica na segunda metade do século } \\
\text { XX }\end{array}$ \\
\hline 2. Relações de produção & $\begin{array}{l}\text { - Liberdade de propriedade } \\
\text { Divisão entre os sexos nas sociedades indígenas } \\
\text { brasileiras } \\
\text { Camponeses e escravos no Egito Antigo e/ou Império } \\
\text { Inca } \\
\text { - Propriedade e exploração } \\
\text { Burguesia e operariado na Revolução Industrial } \\
\text { Terceirização, desemprego e trabalho informal no } \\
\text { mundo contemporâneo }\end{array}$ \\
\hline 3. Transformação do tempo & $\begin{array}{l}\text { - O tempo da natureza } \\
\text { Tempo da coleta e da migração } \\
\text { Tempo de plantar e colher } \\
\text { - Mecanização e fragmentação } \\
\text { Tempo da fábrica } \\
\text { Tempo da informação via satélite } \\
\end{array}$ \\
\hline $\begin{array}{l}\text { 4. Mentalidades: o trabalho no } \\
\text { tempo }\end{array}$ & $\begin{array}{l}\text { - Comparações com paraíso } \\
\text { Vida e trabalho nas sociedades indígenas brasileiras } \\
\text { Castigo e pecado: o trabalho na cristandade medieval } \\
\text { - Reino da fartura e das necessidades } \\
\text { Glorificação do trabalho na ética protestante e } \\
\text { capitalista } \\
\text { Trabalho e alienação nas sociedades industriais. }\end{array}$ \\
\hline
\end{tabular}

Fonte: PCN+ Ensino Médio - Orientações Educacionais Complementares aos PCNs. Ciências Humanas e suas tecnologias. Brasília: MEC/SEMTEC, 2002, p.83-84.

Os outros dois eixos sugeridos são Transporte e comunicação no caminho da globalização e Nações e nacionalismos.

Fica evidenciado que a proposta defende o estudo da História Geral, com menções que vão desde o período neolítico até a atualidade, mas com um predomínio de referencias a temporalidades mais recentes. Entretanto, houve o cuidado deliberado de se evitar qualquer referência à tradicional periodização quadripartite, que pudesse sugerir um programa respeitando uma seqüência 
cronológica linear, que, diga-se de passagem, tem longa tradição, tanto nas propostas curriculares como na organização dos programas de cada escola e nos livros didáticos. Apresenta-se, assim, uma proposta que não é inédita ${ }^{131}$, mas que sabidamente é bastante diferente do que se encontrava nas salas de aula de todo o país. Dadas as condições de trabalho dos professores, e as limitações de formação de muitos deles, a existência de materiais didáticos que atendam a essa proposta, portanto, é uma das condições para sua efetiva implantação em termo nacionais, o que reforça o papel do livro didático como elemento chave na implementação da reforma.

\section{ARGENTINA: O ACORDO MARCO PARA A EDUCAÇÃO POLIMODAL}

Reiterando o princípio geral de que a Educação Polimodal (como o Ensino Médio é denominado nesse país) deve garantir três funções básicas - formação do cidadão, preparação para prosseguir nos estudos superiores e a formação para o trabalho - o documento que orienta a implantação da reforma, denominado Acordo Marco, define que essas funções serão cumpridas por meio de dois tipos de formação: uma Formação Geral de Fundamento e uma Formação Orientada, por sua vez organizada em cinco modalidades curriculares: Ciências Naturais, Economia e Gestão de Organização; Humanidades e Ciências Sociais; Produção de Bens e Serviços e Comunicação, Artes e Desenho. Apesar dessa divisão, os currículos de todas as modalidades deverão ser constituídos de Conteúdos Básicos Comuns (CBC), que asseguram um núcleo comum de formação a todos os jovens ${ }^{132}$, indistintamente, somados aos Conteúdos Básicos Orientados e os Conteúdos Diferenciados, próprios de cada modalidade. Assim, o Conselho Federal de Cultura e Educação, definiu em 1997, como objetivos gerais dos CBC:

131 Para maiores informações sobre as propostas curriculares de História, especialmente a questão da introdução dos eixos temáticos, ver Bittencourt, Circe M. F. "Propostas curriculares de História: continuidades e transformações". In: Barreto, Elba de Sá B. (Org.). Os curriculos do ensino fundamental para as escolas brasileiras. Campinas: Autores Associados; São Paulo: Fundação Carlos Chagas, 1998, p. 127-161.

De modo semelhante ao Brasil, a formulação de um núcleo curricular comum nacional tinha o propósito de garantir um mínimo de homogeneidade aos muitos projetos curriculares então em vigência na Argentina, uma vez que desde os anos 1980, com a descentralização da administração educacional, cada província desenvolvia programações próprias. Disso decorria sérios problemas para os jovens que precisavam migrar de uma província para outra. Cf. Gvirtz, Silvina. "Los contenidos de la escuela en la Argentina de hoy". In: Las transformaciones de la educación en diez años de democracial. Buenos Aires: FLACSO, 1995. 
Los CBC de Ciencias Sociales plantean un conjunto de temas que posibilitan, tal como lo establece la Ley Federal de Educacion N 24.195, que los estudiantes de todas las modalidades de la Educación Polimodal comprendan el mundo actual en relación con la busqueda del bien comun, la consolidación de la democracia, el fortalecimiento de la unidad nacional a partir de la diversidad regional, la conservación del ambiente, la productividad y competitividad económicas y las demandas de un mundo laboral en permanente cambio. Este capítulo incluye un conjunto de saberes básicos de las ciencias sociales de mayor nivel de complejidad y profundidad que en la EGB. Además, se focaliza especialmente en la escala geográfica mundial y en el tiempo histórico contemporáneo. Los contenidos propuestos en este capítulo recogen el aporte de la historia, la geografia, la sociologia, la economia, la antropologia, y la ciencia politica. A través del tratamiento de estos contenidos se propone profundizar la conciencia histórica y territorial con el fin de que el alumno y la alumna puedan percibir, comprender y proyectarse en las coordenadas del tiempo y el espacio, cuestión de importancia vital en un mundo que se transforma aceleradamente en esas dos dimensiones. Es imprescindible que los estudiantes que cursan la Educacion Polimodal cuenten con algunas herramientas teóricas que les permitan analizar y comprender las diferentes dimensiones de la realidad. En consecuencia en este nivel se pondra enfasis en la enseñanza de aportes conceptuales de las diferentes disciplinas sociales, que complementaran el estudio de procesos y casos especificos. Se enfatiza la busqueda, selección, organización y análisis de múltiples fuentes de información adecuadas al nivel de comprensión de los alumnos y a los temas tratados, asi como el ejercicio de la reflexión crítica referida a diferentes problemas sociales. Para ello, interesa el acercamiento de la escuela con la comunidad en su conjunto, y especialmente con el campo académico. La elaboración de las competencias requeridas para la lectura comprensiva de la realidad social, resulta decisiva para la formación de personas capaces de participar en forma autonoma, solidaria y fundamentada en la evaluación y busqueda de respuestas a los problemas de nuestro tiempo, y en el afianzamiento del sistema democrático. Los alcances de contenidos de este capítulo propician la comprensión y explicación del mundo contemporáneo a traves de: - El estudio de las sociedades en relacion con los procesos de globalizacion y la 
diversidad del espacio mundial. - El analisis de los procesos históricos contemporáneos. - La aproximación a la realidad argentina contemporánea.

Observe-se que, ao contrário da proposta brasileira, nesta se menciona explicitamente o período contemporâneo como aquele que deve ser privilegiado na organização dos programas. Por outro lado, de modo semelhante ao verificado no caso brasileiro, também se defende claramente uma abordagem interdisciplinar, envolvendo diversos âmbitos das Ciências Sociais ${ }^{133}$.

Explicando os objetivos próprios de História, encontramos as seguintes orientações:

\section{LOS PROCESOS HISTÓRICOS CONTEMPORÁNEOS}

Síntesis explicativa

Los contenidos de este bloque se articulan con los del anterior en la busqueda de una profundización del conocimiento y la reflexión sobre los procesos históricos mundiales y americanos desde la segunda mitad del siglo XVIII hasta el presente. La inclusión del estudio de los procesos contemporáneos en la Educación Polimodal apunta a profundizar los contenidos propuestos para la EGB, estableciendo una mayor especificidad en el análisis de las problemáticas de la historia mundial y americana y en las diversas perspectivas disciplinarias desde las que se las aborda. Se apuntara a fortalecer la comprensión de las dinámicas propias de los procesos económicos, a través de sus desarrollos históricos contemporáneos, focalizando en las transformaciones del capitalismo y la economia mundial y americana, con especial atención a los procesos de industrialización y los escenarios posindustriales. Se buscará profundizar el estudio iniciado en EGB sobre experiencias políticas en el mundo contemporáneo, incrementando la comprensión de conceptos básicos en torno a la sociedad y la política y focalizando en la cuestión del Estado, los regimenes políticos y los gobiernos, a través de sus desarrollos históricos a partir del siglo XVIII, asi como de los rasgos fundamentales del pensamiento

133 Cabe mencionar que na proposta Argentina, os conteúdos de Filosofia e Psicologia constituem um outro núcleo do $\mathrm{CBC}$, chamados de Humanidades. No caso dos alunos que tenham optado pelos módulos de Humanidades e Ciências Humanas ou de Comunicação, Artes e Desenho, os CBO e o CD aprofundarão os conhecimentos desses dois núcleos do CBC. 
político y social contemporáneo. Se analizara el rol del Estado y la relación de los movimientos sociales con el cambio politico, enfatizando en la comprensión de los desarrollos de la democracia como regimen político, como conjunto de prácticas sociales y de modos de relación entre el espacio público y el privado, y como conjunto de valores. Se ampliara la cuestion de la sociedad civil y su vinculación con el Estado. Desde diversas perspectivas teoricas se profundizará el estudio de los diversos actores y estrategias sociales, de los vínculos familiares y comunitarios y de las redes de relaciones en el contexto de las diversas sociedades y culturas estudiadas. Se fortalecerá la comprensión de nuevas formas de ciudadania politica y social que se desarrollan en el mundo contemporáneo y, en particular, en América. Se introducirá a los estudiantes en el estudio de la complejidad de relaciones que se establecen entre Estado y sociedad, y el proceso histórico de constitución de la sociedad civil en la era contemporánea. Se subrayara la importancia de la participación social en las sociedades democráticas, analizando diversos casos del pasado o el presente, e identificando diversos canales de participación comunitaria, especialmente en la respuesta a situaciones sociales de riesgo. Los contenidos referidos al estudio de la cultura proponen profundizar en los conceptos de cultura y culturas a partir de diferentes perspectivas teoricas. Se focalizará en las cuestiones vinculadas a la identidad y la diversidad cultural, y sus continuidades y transformaciones a través del ciclo contemporáneo. Se analizará la dinámica cultural en las diferentes sociedades históricas y contemporáneas estudiadas, teniendo en cuenta el mundo de las ideas, los valores, las diversas concepciones, creencias religiosas y mentalidades y sus formas de expresión, y analizando algunas de las tendencias culturales contemporáneas. En ese marco se enfatizará el analisis y la comprensión de los fenómenos culturales juveniles. En el estudio de las diferentes dimensiones - económica, politica, social o cultural - que abordan los contenidos propuestos en este bloque, se enfatizará la aproximación de los estudiantes a diferentes perspectivas teóricas, y se focalizará en la historia de las ideas, a través de la lectura de textos seleccionados de autores significativos. La selección de textos se realizará teniendo en cuenta una equilibrada presentación de diversas corrientes de pensamiento y contextos 
históricos, tanto a nivel mundial como americano, adecuada al nivel de comprensión de los estudiantes.

Os elaboradores da proposta não tiveram as mesmas preocupações que verificamos no Brasil no sentido de não se elencar conteúdos; o documento apresenta orientações que identificam um conjunto de temas que devem compor os programas. Merece menção, também, a reiterada referência ao estudo de temas relacionados à História da América, o que não se verifica nos documentos brasileiros $^{134}$.

Dadas essas grandes balizas, o documento vai além e elenca um conjunto de conteúdos conceituais e procedimentais a serem desenvolvidos, admitindo, contudo, que ele poderá resultar em diferentes arranjos programáticos:

Sociedad y procesos económicos

El sistema capitalista y la economia mundial.

El proceso de industrialización europeo y norteamericano en los siglos XVIII al XX.

La organización de la economia y la cuestion social.

La expansión colonial del siglo XIX, y su impacto en las economias colonizadas.

Los procesos emancipadores latinoamericanos del siglo XIX y el desarrollo de economias de exportación primária.

Ciclos económicos latinoamericanos: diversas experiencias nacionales.

El sistema económico mundial durante el siglo XX.

Los escenarios posindustriales.

La revolución tecnológica y su incidencia en el mundo del trabajo, en la producción y el consumo. Su impacto en las economias latinoamericanas.

Sociedad y politica

Las revoluciones americanas y europeas de los siglos XVIII y XIX.

134 A palavra América não é registrada em nenhum momento na parte concernente à História nos documentos brasileiros. 
Los Imperios coloniales y los procesos de descolonización y de organización política de diferentes areas socioculturales: África negra; el mundo musulman; las sociedades asiáticas.

La cuestión de las nacionalidades en el siglo XIX y XX.

Estado y sistemas políticos.

Estado, regimen politico y gobierno: diversas conceptualizaciones.

El pensamiento político y social contemporáneo: el liberalismo, el socialismo, la Doctrina social de la Iglesia, entre otras.

Experiencias políticas mundiales y americanas.

Los conflictos contemporáneos y los esfuerzos por la paz.

Diferentes experiencias históricas en la resolución de conflictos. Estado, movimientos sociales y cambio político en el mundo contemporáneo: voluntad popular, participación ciudadana y consensos políticos.

Desarrollos de la democracia como regimen político, como conjunto de prácticas sociales y de modos de relación entre el espacio público y el privado, y como conjunto de valores.

\section{La sociedad civil}

Los actores y estrategias sociales.

La sociabilidad contemporánea; las estrategias familiares y comunitarias.

Grupos sociales y redes de relaciones en distintos medios socioculturales.

Situaciones sociales de riesgo: accion pública e iniciativa social.

Principales formas de discriminación en el mundo contemporáneo.

Relaciones Estado-sociedad.

Procesos históricos de configuración de la sociedad civil.

Participación social en las sociedades democráticas.

Actores, organizaciones e instituciones sociales

Sociedad y cultura

Cultura y culturas: conceptos.

La identidad y la cultura: continuidades y transformaciones a en el ciclo contemporáneo. 
La diversidad cultural.

La dinámica cultural en diferentes sociedades: ideas, concepciones, creencias religiosas y mentalidades y sus formas de expresion. Las tendencias culturales contemporáneas.

Diversas identidades y tendencias globales. Integración y multiculturalidad en las sociedades contemporáneas.

Manifestaciones culturales juveniles.

\section{PROCEDIMENTALES}

Selección y utilización crítica y adecuada de fuentes históricas, políticas, económicas, sociologicas y antropólogicas.

Lectura de obras o fragmentos de textos de autores representativos de diversas corrientes de pensamiento y contextos históricos contemporáneos.

Lectura critica y reflexiva de información periodistica, de materiales de divulgación y de bibliografia especifica.

Aplicación de conceptos y principios de las ciencias sociales en el análisis de los procesos mundiales y americanos contemporáneos.

Asociación de conceptos en la elaboración de níveles mas altos de interpretación y explicación de los procesos sociales, económicos, políticos y culturales.

Comparación de casos y procesos comprendiendo las similitudes y diferencias entre experiencias en diversos contextos espaciotemporales.

Planificación y realización de investigaciones escolares sobre procesos contemporáneos.

O documento apresenta ainda as "expectativas de logros" que os alunos devem atingir, sendo eles de duas ordens: conceituais e procedimentais, o que reforça o caráter prescritivo da proposta:

Al finalizar la Educación Polimodal, los estudiantes estarán en condiciones de: 
- Relacionar el analisis de los procesos historicos con la comprension de la realidad contemporánea.

- Comprender y comparar diferentes procesos de industrialización y posindustrialización, y familiarizarse con algunos de los principales procesos económicos contemporáneos.

- Reconocer y valorar criticamente las diferentes tradiciones y experiencias políticas y sociales contemporáneas.

- Comprender y valorar la democracia en sus desarrollos históricos contemporáneos.

- Reconocer y analizar los principales fenómenos y tendencias sociales y culturales presentes en el mundo contemporáneo.

Pode-se dizer, assim, que as deliberações das autoridades federais argentinas acabaram estabelecendo, ao menos teoricamente, margens mais estreitas de liberdade para as instâncias provinciais e locais (escolas) formularem seus planos curriculares. Por outro lado, é inegável que os desenhos curriculares propostos são bastante ambiciosos, exigindo uma série de recursos, tanto materiais como humanos, para serem efetivamente implementados.

Quando analisamos os conteúdos procedimentais que constituem o quarto bloco dos CBC de Ciências Sociais, bem como os conteúdos atitudinais, que constituem o quinto e último bloco, percebe-se a intenção dos formuladores da proposta de tornar esses dois âmbitos transversais aos blocos de conteúdos conceituais (relativos à geografia, à História geral e à História Argentina), o que demonstra a influência da proposta espanhola ${ }^{135}$.

Retomando as considerações de Bourdieu, para quem os currículos ou os programas indicam um campo cultural de uma dada época, podemos dizer que o ensino de História tanto na Argentina como no Brasil, ao menos no plano das propostas oficiais nacionais, é concebido como uma área de conhecimento importante e bastante abrangente, especialmente pelo que ela proporciona para a compreensão do presente. Embora entre os historiadores essa idéia possa parecer um tanto quanto óbvia, ela é, no âmbito da história escolar, relativamente

135 No Brasil essa influência também pode ser notada, especialmente nos PCNs do Ensino Fundamental, em que se inserem os chamados Temas Transversais, que percorrem todos os conteúdos conceituais e todos os ciclos. Sobre essa questão ver Coll, César. Os conteúdos da Reforma. Porto Alegre: Artmed, 1998. 
nova, uma vez que até recentemente predominava uma concepção segundo a qual o estudo de história se justificava porque oferecia ao aluno a oportunidade de adquirir um certo repertório de informações, sobre a trajetória da humanidade em geral, e do seu país em particular, cujo final resultava no estudo do presente. Não era o presente que orientava o estudo do passado; bem ao contrário, ele era, freqüentemente, o maior ausente. Desse modo, em ambas as propostas recomenda-se uma abordagem no estudo da história em que a relação entre o passado e o presente sejam uma constante, o que representa uma das mais importantes inovações e, por via de conseqüência, um dos maiores desafios para a sua implementação ${ }^{136}$. Reside aqui um é importante aspecto a se verificar nos livros didáticos: em que medida eles procuram propiciar a reflexão sobre essa relação, atendendo essa orientação?

Merece destaque o fato de que, tanto na Argentina como no Brasil, apesar das grandes transformações havidas desde a institucionalização da história como disciplina escolar, no século XIX, ela continua sendo vista como essencial para a formação dos cidadãos - reconhecendo-se naturalmente que não se trata da mesma concepção de cidadão do século XIX - o que implica dizer que continua central nessa disciplina o seu papel de construtora de identidades e de preservadora de memórias coletivas. Nesse sentido, a análise dos livros didáticos pode ajudar a compreender que tipo de identidade ele ajuda a (re)construir e de que memórias se tratam, sobretudo se levarmos em conta o cenário de transformações profundas verificadas na passagem do século passado para esse, quando os livros estavam sendo produzidos ${ }^{137}$.

136 No caso brasileiro, desde os anos 1980 diversas propostas curriculares estaduais já apresentavam essa abordagem, com maior ou menor êxodo em sua implantação. De todo modo, são nos PCNs que ela se apresenta, pela primeira vez, em uma proposta de caráter nacional. Dentre os vários autores que trataram dessa questão, ver Bittencourt, Circe M. F. "Propostas curriculares de História: continuidades e transformações". Op. cit; Cordeiro, Jaime. A História no centro do debate. São Paulo: Cultura Acadêmica, 2000 e Fonseca, Selva Guimarães. Os caminhos da História ensinada. Campinas: Papirus: 1983.

137 É vasta a bibliografia sobre a relação entre ensino de história, livros didáticos e construção de identidades. Contudo, toda essa bibliografia sempre toma a História pátria como referência, ou seja, procura analisar a relação entre os livros didáticos de História nacional (dos mais diversos países) e a questão da identidade nacional. Nosso estudo, nesse sentido, procura ir um pouco além, na medida que tomamos como objeto os livros que tratam de história geral e, portanto, em última instância, possibilitam aos estudantes estabelecer algum vínculo entre eles, seu país e o mundo, formulando uma concepção de identidade para além das fronteiras nacionais. Essa questão, que nesse estudo é especialmente relevante, será aprofundada no próximo capítulo. 
$\mathrm{Na}$ impossibilidade de varrer dezenas de séculos, a partir de uma perspectiva que toma a história desde as origens das sociedades humanas, e as perseguem ao longo do tempo, até chegar ao presente, tanto a proposta brasileira como a argentina descartam o estudo de "toda a história". No entanto, os caminhos que são propostos são bastante distintos. Enquanto no Brasil se propõem estudos a partir de eixos temáticos (cidadania, cultura e trabalho, história das técnicas e tecnologias, nação e nacionalismo são os exemplos oferecidos), contemplando-se diversos espaços e diversas temporalidades, na Argentina se mantém uma periodização clássica: privilegia-se o estudo do período contemporâneo, tendo a Europa e a América como foco.

E no México, como essas questões se apresentam?

\section{MÉXICO: UMA DISCUSSÃO A FAZER}

No caso mexicano, embora a reforma educacional tenha de algum modo atingido a Educação Média Superior, no plano dos currículos somente muito recentemente é que se passou a discuti-los de modo mais profundo ${ }^{138}$. Primeiro, porque, como dissemos anteriormente, o foco do governo mexicano estava no nível secundário e, segundo, porque o Ensino Médio tem naquele país uma estrutura extremamente complexa. Do ponto de vista institucional, as escolas de EdMS podem ser federais, estaduais, autônomas e particulares, sendo que a SEP não tem ingerência sobre todas elas. As instituições autônomas, como o caso dos cursos oferecidos pelas universidades, devem se submeter aos dispositivos da Ley General de Educación, mas não são obrigadas a seguir determinações do órgão federal de educação. Mesmo o organismo criado para oferecer algum grau de coordenação para esse nível de ensino, denominado CONAEMS, parece pouco efetivo ${ }^{139}$. A própria Ley General de Educación, no seu artigo 48, não assegura à SEP sequer poderes com relação à definição dos planos e programas curriculares para a EdMS, embora seja sua atribuição fazê-lo com relação a

138 A partir de 2004 tiveram início várias iniciativas ligadas a EdMS, algumas delas resultando em novas propostas curriculares, como uma destinada aos cursos de EdMS tecnológicos.

139 Embora reúna as mais importantes instâncias e instituições vinculadas a EdMS, o CONAEMS parece não dispor de força ou disposição para promover uma ação mais ordenada. Desde os anos 1970 se solicita que as universidades e as instituições públicas deixem de oferecer cursos de bachirllerato, para que esses passem a ser responsabilidade da SEP, mas até o momento tal meta não foi alcançada. Cf. Castanón, R. y Seco.Op. cit. p. 99 
educação primária, secundária, educação normal e as demais voltadas para a formação de professores de educação básica ${ }^{140}$.

Disso decorre que, diferentemente do Brasil e da Argentina, não há no México um documento contendo orientações curriculares válidas ou obrigatórias para todo o país. Contudo, pela força da tradição, os cursos de bachillerato oferecidos pela UNAM, tanto por meio das Escolas Nacionais Preparatórias como pelos Colégios de Ciências Humanas, continuam servindo de modelo ou parâmetro para os cursos desse tipo oferecidos por outras universidades, escolas estaduais e mesmo instituições particulares ${ }^{141}$. Daí porque grande parte dos alunos que cursa essa modalidade educacional dedica um ano ao estudo da Historia Geral, com ênfase no período contemporâneo, dedicando um outro ano ao estudo da História do México e, dependendo da opção que pretende fazer ao ingressar no nível superior, uma terceira disciplina, como História da Cultura ou História da Revolução Mexicana. Desse modo, o documento denominado Núcleo de Conocimientos y Formación Básicos que debe proporciar el bachillerato de la UNAM (NCFB) pode ser tomado como uma referência sobre o ensino de História Universal Moderna e Contemporânea verificado em muitas escolas. Nele se fixam os seguintes postulados:

- Concebir a la historia como un proceso en cuya conformación intervienen diversos aspectos interrelacionados que, en ciertas circustancias, algunos de ellos adquieren mayor relavancia, dejando atrás enfoques sustentados en la simples transmisión y acumulación de información sobre personajes, fechas o acontecimientos.

- Atender el carácter multicausal y relación dialéctica que subyce en todo proceso.

- Considerar la ubicación de los hechos históricos representativos en las coordenadas tiempo-espacio.

- Enfatizar las continuidades y rupturas que se dan en el acontecer histórico, vinculandolas al proceso histórico global en estudio, para no apresentarlas como actos aislados.

- Considerar el papel de los diferentes actores de la historia. o que reforça o seu peso, além do fato de que o ingresso nessa universidade é a meta almejada de muitos estudantes. 
- Atender en todo momento la relación entre presente y pasao, para explicar compreender el proceso de formación de los rasgos que caracterizan a nuestro entorno actual.

- Ubicar los conceptos de orden histórico en función del significado que adquiren en un contexto o proceso determinado.

Entretanto, é interessante observar que, também nesse documento, se fala em conhecimentos, habilidades, atitudes e valores, dentro dos mesmos princípios de "deber saber, deber hacer y saber valorar", o que denuncia também no México a influência dos modelos educacionais mencionados anteriormente.

No tocante aos conhecimentos históricos em geral, são elencados 6 itens:

1. La Historia, su objeto y utilidad.

2. La interpretación histórica.

3. Los sujetos da la Historia.

4. Tiempo y espacio en la Historia.

5. Las fuentes de la Historia.

6. La investigación histórica.

Eles se desdobram, em um segundo momento, em uma lista de objetivos ou desempeños correspondientes, como é chamado no documento, composta de 45 itens.

No que tange à História Universal, os conteúdos estão organizados a partir de três grandes temas:

1. La transición del feudalismo al capitalismo en Europa

2. Los procesos históricos que hacen posible: la consolidación capitalista, la formación del imperialismo y los orígenes del socialismo.

3. Los procesos históricos que conducen de la crisis del capitalismo y el surgimiento del socialismo, a la crisis del sistema socialista y la apertura de nuevas perspectivas del mundo al final del siglo $X X$.

Percebe-se, evidentemente, um privilegiamento do âmbito econômico, mais especificamente da história do capitalismo. É interessante notar que, 
reconhecendo grande semelhança entre os conteúdos programáticos do bachillerato com aqueles desenvolvidos na etapa anterior, da educação secundária, o documento registra que na verdade tratam-se de desempenhos distintos, pois nesse novo ciclo escolar "no se trata em modo alguno de repetir lo que se supone debe saber ya el alumno que ingresa al bachirellato. En ese sentido, en el NCFB se enfatiza el desarollo de habiliddes intelectuales de orden superior a la memorización ${ }^{142}$. Registre-se que não se considera esses saberes como conhecimentos prévios dos alunos, a partir dos quais outros poderão ser construídos, mas se considera que agora os alunos desenvolverão uma outra ordem de habilidades intelectuais, tratando-se, pois, de um "outro" conhecimento.

A listagem de objetivos (com 34 itens, sendo que os dois últimos se desmembram em outros 15 e 9 itens respectivamente) relativos à compreensão histórica segue modelo clássico, começando sempre com verbos que indicam determinadas habilidades, como se vê na listagem referente ao tópico sobre a origem do capitalismo ema Europa, nos séculos XV e XVI:

Relaciona la ciudad y los orígenes del capitalismo a través de:

- El impulso del comercio y desarrollo de las ciudades.

- El surgimento de la burguesia

- Describe el surgimiento y desarrollo de los primeros estados nacionales: Francia, Inglaterra, Espanã ${ }^{143}$.

- Compreende la importancia del renacimiento, el humanismo, el desarrollo del pensamiento científico y el desarrollo tecnológico.

- Ubica los grandes descubrimientos geográficos y por qué la expansión colonial europea.

- Reconoce la acumulción de metales preciosos y sus efectos. Identifica a los imperios europeus de la época.

- Compreende la ruptura de la unidad religiosa: reforma y contrarreforma y la secularización de la vida social e cultural.

- Reconoce el papel de América en este proceso.

\footnotetext{
Idem p. VIII-4.

143 Note-se: não se menciona Portugal.
} 
A essa lista se segue um conjunto de conceitos que devem ser especialmente focados:

Feudalismo, vasallaje, autarquia, grêmios, guildas, burgos, ciudad, burguesia, mercantilismo, acumulación originaria de capital, capitalismo, monarquia, renacimiento, humanismo, colonización, Império, estado-nación, reforma, contrarreforma.

O mesmo é feito com os demais tópicos, de modo que, pela "listagem dos conceitos" (como são identificados no documento) que são indicados como os centrais, pode-se ter uma boa dimensão do programa proposto:

Revolución agrícola, Revolución Industrial, Revolución económica, politica y social, clase obrera, sistema fabril, capitalismo industrial, Antiguo Régimen, Estado, Absolutismo, República, ciudadano, patria, nación, nacionalismo, independencia, ilustracion; Congreso de Viena, Santa Alianza, conservadorismo, proletariado, lucha de classes, anarquismo, asociacionismo, mutualismo, colectivismo, Las Internacionales, socialismo utópico, marxismo, La Comuna de Paris, División Internacional del Trabajo, neocolonialismo, imperialismo, Destino Manifesto, Guerra de Secesión,liberalismo económico y liberalismo político, nacionalismo, migraciones mundiales,potencias emergentes mundiales, shogunato y restauración Meiji, Segunda Revolución Industrial; Taylorismo, New Deal, regímines políticos, fascismo, nacional-socialismo, estado oligárquico, estado populista, vanguardias culturales, zarismo, revolución proletaria, los Soviets, stalinismo, Guerra Fria, mundo bipolar y multipolar, bloques de poder, lucha ideológica, coexistencia pacífica, zona de influencia, la descolonización, los alineados, los no alineados, Primer, Segundo y Tercer Mundos, movimientos de liberación nacional, movimientos culturales y artísticos de la época; la Perestroika, el nuevo Orden Internacional, Unión Europea, Regiones Geoeconómicas, TLC, Reunificación Alemana, dependencia, estado benfector, capitalismo tardio, guerra de baixa intensidad, Guerra de las Galaxias, capitalismo financeiro, contracultura, hegemonia, bloque socialista, sociedad de masas, sociedad de consumo.

Percebe-se, assim, como o modelo que orienta os programas de muitos professores mexicanos oferece margens ainda mais estreitas do que as dadas 
para seus colegas argentinos, pelo menos segundo o que o programa predominante estabelece, pois são listados tópicos bastante específicos a serem contemplados $^{144}$. Se considerarmos que todo esse programa corresponde apenas a um ano letivo, não é exagero concluir que resta pouca liberdade para os professores incluírem em seus programas outros temas e questões, menos ainda abordá-los desde outras perspectivas historiográficas, uma vez que claramente se aponta para um viés marxista de análise.

Soa muito familiar aos professores brasileiros a organização dos conteúdos acima mencionados, a ponto de se poder dizer que, salvo a barreira da língua, um professor de nosso país poderia perfeitamente lecionar História Geral em escolas mexicanas e vice-versa. Ainda são comuns no Brasil modelos de planejamentos anuais (muito em voga nos anos 1980) que se estruturam a partir da listagem de conteúdos, objetivos e conceitos centrais, tal como vemos no México.

Podemos dizer, então, que enquanto propostas curriculares prescritas, a brasileira e a Argentina possuem muitas semelhanças, ainda que se reconheça na primeira uma ousadia um pouco maior, por propor o rompimento com o estudo cronológico linear, fundada na periodização tradicional quadripartite (História Antiga, Medieval, Média e Contemporânea). Já o programa seguido nos cursos de EdMS da UNAM se distancia desse desenho, ainda que ele se assemelhe muito à prática de muitos professores brasileiros.

\section{CURRÍCULOS, PROPOSTAS CURRICULARES E A ANÁLISE DOS LIVROS DIDÁTICOS}

Tendo em vista todas esses aspectos abordados ao longo deste capítulo, podemos finalmente formular o problema que nos toca mais diretamente: em que medida essas orientações curriculares pré-ativas estão ou não presentes nos livros didáticos desenvolvidos para serem usados nas salas de aulas? As diferenças verificadas em cada um dos países implicam em diferenças nos manuais produzidos para atender esse nível escolar? Como esses aspectos todos

144 Nesse sentido, a advertência de que a lista de conhecimentos, habilidades, atitudes e valores básicos apresentados não corresponde a um programa de estudos, podendo-se propor outras experiências de aprendizagem parecem apenas um recurso retórico dos elaboradores do documento. Ver. Desempeños correspondientes a Historia Universal Moderna Y Contemporânea e Historia de México - Apresentación, p. VIII - 2 ( versão de Maio de 2000). 
interferem na concepção de história e de ensino presente nessas obras? Em que medida pode-se perceber a efetivação nas salas de aula das propostas que se orientam pelo paradigma das competências ou por novas abordagens históricas, como a dos eixos temáticos? A produção editorial pós-reforma indica que autores e editores procuraram atender a essas novas propostas ou, ao contrário, mantiveram-se fiéis a cânones mais consolidados, pressupondo que os professores continuariam presos aos programas "tradicionais" ? 


\section{Capítulo III}

\section{OS LIVROS DIDÁTICOS DE HISTÓRIA PARA O ENSINO MÉDIO}

El manual segue sendo necesario en la escuela y, aunque su inevitabilidad no conduce a la fatabilidad, exige, como mínimo, la posibilidad[...].

Jesus Garcia Minguez

Neste capítulo começamos efetivamente a análise dos seis livros selecionados. Inicialmente, apresentamos algumas considerações sobre as pesquisas que tomam os livros didáticos como fonte, destacando as principais linhas de investigação e apontando a qual delas o presente trabalho se filia. Apresentamos também um quadro geral das pesquisas em torno desse objeto nos três países.

Em um segundo momento, caracterizamos as obras selecionadas quanto a seus autores e equipes que as produziram. Em seguida, as analisamos seus aspectos físicos e visuais, chamando a atenção para a relação entre o projeto gráfico e as propostas pedagógicas que as sustentam.

O capítulo se encerra com a caracterização das concepções de História explicitadas pelos autores, ou no texto de apresentação ou no capítulo introdutório, partes geralmente destinadas ao esclarecimento do leitor sobre os fundamentos da ciência histórica. Esse tema nos possibilita verificar que concepções os autores têm sobre os conhecimentos prévios que os alunos trazem de sua escolaridade anterior. 


\section{OS LIVROS DIDÁTICOS COMO FONTES DE PESQUISA}

Ao longo do século $X V I$, quando a prensa de tipos móveis começava a se difundir, e em meio a um contexto de intensos conflitos religiosos, que motivou a criação de instituições voltadas para a formação das crianças e jovens ${ }^{145}$, surgiam as primeiras obras destinadas à educação ${ }^{146}$, ainda que essas estivessem muito longe do que concebemos hoje por livro didático. O modelo moderno surgiu no século XIX, e desde então ele tem passado por mudanças significativas. No Brasil, ele surgiu no século XIX, na mesma época em que se instituía um sistema educacional mais articulado e se constituía a escola pública ${ }^{147}$.

Os livros didáticos tornaram-se fontes de pesquisa sobre o ensino há bastante tempo ${ }^{148}$, reflexo do papel central que desempenham nos sistemas educacionais ocidentais. No entanto, são mais recentes os estudos que se inserem no âmbito da História da Educação; tal tendência ganhou impulso a partir dos anos 1960. Ao contrário do que muitos pensam, não são apenas nos países pouco desenvolvidos que os livros didáticos desempenham papel relevante nas práticas escolares. Da Noruega à Argentina, do Japão aos Estados Unidos, é unânime o reconhecimento da importância dessas obras nos sistemas educacionais de inúmeros países ${ }^{149}$. Não é à toa que quase todos eles têm uma legislação específica que regulamenta a produção e/ou a circulação delas. Por essa razão, encontram-se estudos sobre o livro didático das mais variadas nacionalidades.

145 Cf. Choppin, A . "História dos livros e das edições didáticas: sobre o estado da arte". In Educação e Pesquisa, vol 30 no. 3, p. 554, set/dez 2004.

146 Segundo Selander, considera-se Peter Pamus (1515-1572) o criador do livro texto numa época em que se promoviam mudanças no sistema educativo. No século seguinte, Comenius, com sua célebre Didática Magna, foi o primeiro a ressaltar a importância da organização do tempo, das matérias e dos métodos escolares. Cf. Selander, S. Análisis del texto pedagógico. In Garcia Minguez, J. E Beas Miranda, M. Libros texto como construcción de materiales curriculres. Granada: Proyecto Sur de Ediciones, 1995, p. 151.

147 Bittencourt, Circe. Livro didático e conhecimento histórico:uma história do saber escolar.Tese de doutoramento, Departamento de História da FFLCH-USP, 1993, p. 4.

148 Segundo Alain Choppin, nos Estados Unidos estudos com essa temática contam mais de 100 anos, enquanto na Alemanha e Japão eles se desenvolveram desde o final da II Guerra Mundial. Cf. Choppin, A. Op. Cit. p. 551.

149

Entre os muitos autores que realçam esse aspecto, podemos citar Egil Børre Johnsen Libros de texto en el calidoscopio. Barcelona: Ediciones Pomares Corridor, 1996, p. 134; Michel Apple Trabalho docente e textos: economia política das relações de classe e gênero em educação.Porto Alegre:Artes Médicas, 1995, p. 85.e Marisa Lajolo "Livro didático: um (quase) manual de usuário". In Em Aberto Ano 16, no. 69, 1996, p.4. Johnsen ressalva, porém que as formas de uso do livro texto variam muito, segundo os professores, a matéria, o nível escolar, a escola, o estudante e o lar de onde procedem. (p.134). 
Essa importância fez com que os manuais passassem a merecer, desde os anos 1960, atenção crescente por parte de pesquisadores europeus e norteamericanos. Desde então, as abordagens ou as clivagens na seleção das obras estudadas têm variado bastante, apesar da notória predominância dos estudos sobre os conteúdos das obras. A bibliografia disponível sobre o tema na atualidade é considerável, podendo-se mesmo dizer que nas últimas décadas verificou-se uma explosão na publicação de livros e artigos que tenham o livro didático como tema e/ou fonte. Mais recentemente, tem se notado a tendência dos pesquisadores se reunirem em centros ou núcleos, tornando assim os esforços coletivos, o que tem ampliado, aprofundado e facilitado a difusão dos resultados dos trabalhos. O maior problema, no entanto, é que a maior parte dessa bibliografia encontra-se muito dispersa, o que dificulta sobremodo a sua consulta e sistematização, como apontou Alain Choppin ${ }^{150}$.

Uma linha de investigação que vem crescendo mais recentemente é aquela dedicada à análise dos livros e outros materiais impressos usados nas escolas. Orientados pelas reflexões de autores como Roger e Anne Marie Chartier, Robert Darnton, Jean Hébrard, dentre vários outros, esses estudos têm tomado os livros escolares, em especial os didáticos, a partir de uma perspectiva mais ampla, da história do livro, valorizando aspectos ainda pouco estudados, como os da sua materialidade, a sua produção e a circulação dessas obras.

Tal abordagem oferece muitas e férteis possibilidades de investigação, entrecruzando variáveis como mercado editorial, tecnologia editorial e gráfica, legislação sobre os livros escolares, programas de compras oficiais e outras, o que faz com que o objeto livro didático seja colocado dentro de um contexto muitíssimo mais amplo do que aquele visto nos estudos realizados na chamada perspectiva ideológica ${ }^{151}$. A teia de relações a ser analisada, por ser mais

150 Choppin, A .Op. cit.p. 549-551.

$151 \mathrm{Na}$ bibliografia analítica sobre os livros didáticos, denomina-se de perspectiva ideológica uma dada abordagem que entendia os manuais como veiculadores e reprodutores de ideologias dominantes, com o propósito de assegurar a reprodução do status quo. A crítica que se faz hoje a essa abordagem é que ela desconsidera o fato de que ela própria era portadora e veiculadora de ideologias, como de resto qualquer análise, não havendo portanto a isenção ou suposta objetividade que os analistas julgavam ter em suas interpretações. Deste modo, quando nos referimos à "análises ideológicas" em outras passagens deste trabalho estamos nos reportando àquela abordagem, o que não nos isenta de reconhecer que nossa própria investigação se embasa em pressupostos ideológicos e que também nós realizamos uma crítica ideológica dos manuais, ainda que não nos limitemos a isso. 
complexa, é mais difícil de ser estabelecida, mas, por outro lado, proporciona uma visão mais rica e multifacetada. Uma das conseqüências de tal abordagem é que a idéia de autoria passa a ser entendida de modo também mais amplo, indo além daqueles que assinam a obra e passando a abarcar uma equipe de profissionais, que, de vários e diferentes modos, interferem na elaboração, circulação e consumo desses livros, sobretudo quando se investiga a produção mais recente $^{152}$. Nesse trabalho, assumimos essa perspectiva de análise.

Atualmente são bastante diversificadas as linhas de pesquisa: há quem se detenha no estudo da produção de um certo autor ou de uma casa editorial, ou quem analise mudanças gráficas e tecnológicas que interferiram na produção editorial didática. Outros têm procurado investigar questões ligadas à circulação dessas obras ou então buscam compreender como esse recurso é utilizado por professores e alunos; predominam, porém, os estudos que privilegiam os conteúdos, relacionando-os com questões mais amplas, como o currículo e a cultura. Nesse sentido, autores como Gimeno Sacristán consideram que os livros escolares exercem grande influência na formulação dos currículos, a ponto do autor espanhol dizer que os editores muitas vezes decidem na prática os programas que serão desenvolvidos nas salas de aula. Por esse motivo, os livros didáticos seriam responsáveis por uma homogeneização cultural, difundindo um certo repertório de conhecimentos e uma dada visão de mundo. Outros autores, como Jesus Garcia Mínguez, sem negar a importância desempenhada pelos livros didáticos, considera que há mediadores nesse processo que impedem uma maior "pasteurização" cultural. De todo modo, é forçoso reconhecer que os livros didáticos, circulando aos milhões, contribuem para aquilo que Sacristán chama de "consenso cultural mínimo"153. No caso dos livros únicos de circulação nacional, que muitas vezes constituem os únicos livros a que crianças e jovens têm acesso,

152 Na segunda metade dos anos 1990 houve importantes mudanças nos procedimentos editoriais para a produção dos livros didáticos no Brasil. Esses deixaram de ser uma obra autoral, no sentido de serem fortemente ancorada nos originais de um autor, que constituíam a base de todo o trabalho editorial, para se constituir em um produto mais sofisticado, com apoio de vários tipos de assessoria técnica, que constroem conjuntamente a obra. Um bom indício desse fenômeno pode ser notado na página de créditos, onde, em geral, todos os colaboradores têm seus nomes inscritos. Os processos de avaliação das obras por parte de comissões designadas pelo MEC, associados a cronogramas cada vez mais apertados para 0 desenvolvimento das obras, visando o atendimento dos seguidos programas governamentais, contribuíram para consolidar essa prática de envolver grande número de pessoas no desenvolvimento dos livros.

153 Sacristán, G. "Materiales y textos: contradiciones de la democracia cultural". In Garcia Minguez,J. e Beas Miranda, M. Op. cit. p. 79. 
essa questão assume contornos ainda mais graves, pois sabemos que essas obras veiculam não apenas informações, mas valores sociais, conhecimentos socialmente valorizados e ajudam a forjar identidades. Por outro lado, tanto no campo do currículo como da produção desses livros se estabelecem campos de luta, em que forças defensoras de uma certa tradição cultural enfrentam outras dispostas a promover mudanças. Isso dá uma medida do quão intrincada é a análise desse objeto.

Ainda assim, percebe-se em boa parte dos estudos mais recentes um traço comum: a abordagem cultural, segundo a qual os livros didáticos são resultantes de muitas variáveis e de muitas mediações sociais, historicamente construídas ${ }^{154}$. Desse modo, tornam-se mais raros os estudos que tomam essas obras encerradas em si mesmas. Michel Appel, nesse sentido, adverte que elas devem ser estudadas inseridas nas relações entre educação e sociedade, relações essas marcadas por tensões e contradições, por reproduções, mas também por resistências $^{155}$.

Alain Choppin é um dos autores que têm dado importantes contribuições para uma reflexão mais teórica sobre essas questões ${ }^{156}$, alertando para a necessidade dos estudiosos desse campo considerarem aspectos pouco explorados, como por exemplo os processos de produção e os vários tipos de mediações que eles pressupõem, inclusive os tecnológicos, que interferem no modo como esses livros serão usados (ou rejeitados) pelos professores e alunos. Além disso, ele destaca o papel do Estado (como comprador ou legislador) ${ }^{157}$ e do

154 Choppin, A. Les manuels scolaires. Histoire et actualité. Paris: Hachette Éducacion, p. 198.

155 Apple, M. Educaçao e poder.Porto Alegre: ArtMed, 1989, apud Bittencourt, Circe. Op. cit. p. 7.

156 Alain Choppin é responsável por um grande projeto em torno de livros didáticos junto ao Institut Nacional de Recherche Pédagogique (INRP), na França, do qual resulta o banco de dados EMMANUELLE Esse banco é desenvolvido com o apoio INRP, sediado em Paris, e que disponibiliza suas informações por meio da Internet. Convênios com instituições de vários países, possibilitam que por meio desse banco os pesquisadores tenham acesso a informações sobre livros didáticos para além da França. Para maiores informações consultar: www. inrp.fr/she/emmanuelle.htm.

157 A questão das políticas públicas sobre o livro didático tem motivado a produção de alguns textos. Dentre eles podemos mencionar Politcas del libro texto escolar, do espanhol Jaume Martinez Bonafé e "Las políticas em libros escolares em el mundo", do próprio Choppin. Segundo Munakata, no entanto, no Brasil é ainda incipiente essa linha de investigação, em que se destacam os pioneiros trabalhos de Heloísa Höfling, em que a autora procura constituir uma cronologia das políticas governamentais para a área. Munakata, Kazumi. "Investigações acerca dos livros escolares no Brasil: das idéias à materialidade". In: História de las ideas, actores, intituces educativas. Memória Del VI Contreso Iberoamericano de Historia de la Educación Latinoamericana, San Luis Potosi (versão em CD-ROM), 2003. 
próprio desenvolvimento do capitalismo como fatores relevantes no estudo dos livros didáticos, em particular de sua história.

O mesmo autor observa que os desafios educativos postos nas últimas décadas têm contribuído para uma importante mudança de abordagem:

Nos anos 1970 opera-se, progressivamente, uma mudança de perspectiva na análise de conteúdos dos antigos manuais escolares. As dificuldades vividas então pelos principais sistemas educativos ocidentais levam os pesquisadores a se interrogarem sobre as finalidades do ensino, sobre seus conteúdos e métodos e, entre outras coisas, a colocarem aos antigos manuais escolares questões de natureza epistemológica e didática propriamente dita: qual(s) concepção(s) de história, qual(s) teoria(s) científica(s) ou qual(s) doutrina(s) linguística(s) representam ou privilegiam? Qual o papel que atribuem à disciplina? Que escolhas são efetuadas entre os conhecimentos? Quais são os conhecimentos fundamentais? Como eles são expostos, organizados? Quais os métodos de aprendizagem (indutivo, expositivo, dedutivo, etc.) são apresentados nos manuais ${ }^{158}$

É interessante ressaltar que boa parte dos estudos realizados segundo essa perspectiva refere-se a livros de História e leitura, ainda que já se disponha de trabalhos em áreas que até recentemente contavam com poucos trabalhos, como a Física e a Química ${ }^{159}$.

Michel Apple afirma que os livros didáticos legitimam os conhecimentos veiculados em classe ${ }^{160}$. No entanto, é importante não perder de vista que a apropriação que o leitor faz da mensagem contida em um texto não é necessariamente aquela que o autor ou o editor almejavam ${ }^{161}$. Nesse ponto da recepção textual se estabelece uma tensão importante, mas difícil de ser abordada: o texto didático, tal como o texto científico, é elaborado de modo a assegurar um determinado entendimento da informação ou da interpretação

158 Choppin, Alain. "História dos livros e das edições didáticas: sobre o estado da arte". In Educação e Pesquisa, vol 30 no. 3, set/dez 2004, p. 558.

159 Idem, ibidem.

160 Apple, M. Op. cit. p. 85.

161 Estudos realizados na França e na Alemanha desde meados dos anos 1980 têm demonstrado a influência efetiva dos livros didáticos na formação das mentalidades, cf. Choppin, A. Op. cit. P. 565. 
veiculada. Para isso faz-se uso de recursos lingüísticos que visam eliminar o tanto quanto possível a ambigüidade, supondo sempre um leitor modelo, implícito ao texto. Protocolos de leitura também são usados, como por exemplo os exercícios de verificação do entendimento do texto, em que o leitor deve se limitar a reproduzir o que o próprio diz. Ocorre que entre o leitor modelo e o leitor real há um mediador com um papel muito importante: o professor. Esse mediador é muito mais forte que o autor, pois em última análise é ele que tende a determinar o significado dos textos, por meio de suas explicações e das avaliações. Ele pode mesmo se sobrepor ao autor, o que é inclusive desejável, demonstrando aos alunos que os conhecimentos são criticáveis e superáveis. Portanto, as concepções originais do autor podem ser apreendidas pelos alunos de modo bastante distinto. Mas, por outro lado, é preciso considerar que na maior parte dos casos são os próprios professores que escolhem os livros que seus alunos utilizam durante as aulas, e provavelmente escolhem aqueles que apresentam maior grau de concordância com suas próprias concepções. É nesse intervalo entre as intenções do autor e o uso que o professor faz do texto que os livros didáticos atuam, o que os colocam entre dois limites: o da prescrição e o de recurso ${ }^{162}$.

\section{A FUNÇÃO DOS LIVROS DIDÁTICOS}

Segundo Choppin, os livros didáticos tiveram papel central na construção das identidades nacionais, juntamente com a moeda, a bandeira e os símbolos nacionais, durante o processo de consolidação dos Estados Nacionais, uma vez que eles se constituíram em um recurso acessível a parcela crescente de crianças e jovens, e na medida mesmo que esses Estados criavam e ampliavam a rede escolar pública. Ele afirma que os manuais escolares são instrumentos de coesão cultural de um país, contribuindo para a sua identidade ${ }^{163}$. Durante muito tempo,

162 As pesquisas voltadas para o uso dos livros didáticos tendem a jogar mais luz sobre essa questão, como vemos no trabalho de Luciana Telles de Araújo, O uso do livro didático no ensino de História: depoimentos de professores de escolas estaduais de ensino fundamental situadas em São Paulo. PUC-SP, 2001, dissertação de mestrado. Diversos autores discutem a questão do nível de controle dos livros didáticos sobre os professores, ou, dito de outro modo, da autonomia dos mestres frente as prescrições que trazem, como por exemplo Johnsen, B. Op. cit. p. 145.

163 Nesse sentido, as disciplinas de Língua Nacional e História desempenham papel especialmente relevante. Choppin, Alain. "Las políticas de libros escolares en el mundo: perspectiva comparativa e historica" In Perez Siller, J. E Radkau Garcia. V. Identidad en el imagiario nacional: reescritura y enseñanza de la Historial. Puebla: Instituto de Ciencias Sociales y Humanidades/Colegio de San Luis; Brauschwerg: Institut George Eckert, 1998, p. 169. 
para as parcelas mais pobres da sociedade, os livros escolares eram uns dos

poucos, senão o único, artefato da cultura letrada acessível a elas, veiculando valores e comportamentos tidos como patrióticos, logo, próprios dos cidadãos. Essa seria a função mais antiga que os livros didáticos desempenha: a função cultural-ideológica. Eles desempenham ainda, segundo o mesmo autor, mais três funções centrais: referencial, instrumental e documental ${ }^{164}$.

A função referencial está associada ao fato deles reproduzirem fielmente os programas oficiais, ou, no caso de não haver um programa único, de fornecerem uma versão para o desenvolvimento da programação escolar, devidamente organizada e sistematizada, considerando o sistema escolar ao qual visam atender. Os livros didáticos, portanto, são depositários de um conjunto de conhecimentos socialmente relevantes, em geral formalmente estabelecidos nos programas curriculares das disciplinas escolares, os quais, por sua vez, resultam de um jogo de forças sociais historicamente determinadas.

A função instrumental é conseqüência da anterior: os conhecimentos contidos nos livros didáticos são arranjados a partir de certos métodos de aprendizagem, entendidos como os melhores ou como facilitadores para a transmissão dos mesmos. Portanto, todo livro expressa necessariamente uma concepção, mais ou menos bem desenvolvida e teoricamente embasada, de aprendizagem e de conhecimento.

A função documental refere-se ao fato de que todo livro didático constitui-se em um conjunto de textos, imagens e outros recursos a partir dos quais os alunos desenvolvem seu senso crítico, ou seja, pensam, questionam, interpretam, etc. Quanto mais compromissados com a autonomia intelectual dos alunos, mais essas competências são estimuladas pelos livros. Isso, na verdade, pode ser entendido como uma função potencial, pois sua concretização vai depender do modo como o livro será usado pelo professor e pelo aluno.

Choppin adverte que essas funções estão muito inter-relacionadas, chegando mesmo a se fundir. Esse é um dos motivos pelos quais a análise dos 
livros didáticos é muito complexa, envolvendo muitos sujeitos que neles interferem: Estado, família, editores, professores, alunos, movimentos sociais e outros $^{165}$. Isso ajuda a entender porque as antigas análises restritas apenas aos conteúdos por eles veiculados tornaram-se insuficientes. O desafio é contemplar os aspectos de sua produção assim como os associados ao seu uso, o que é especialmente difícil, pelo esforço que a pesquisa implica ${ }^{166}$. Por outro lado, à medida que foram aumentando em quantidade, e ganhando circulação mais ampla, os estudos possibilitaram debates nacionais e, mais recentemente, internacionais, proporcionando múltiplas interpretações e, conseqüentemente, um salto qualitativo no debate. São evidentes os avanços metodológicos havidos nos últimos anos, o que tem se potencializado com os intercâmbios entre os centros de pesquisa, ao mesmo tempo que têm possibilitado a identificação de influências e empréstimos vindos do exterior na produção dos livros, a despeito do seu caráter fortemente nacional $^{167}$. O mesmo pesquisador francês pondera que 0 deslocamento das análises ideológicas para um enfoque mais epistemológico e didático tem feito com que os estudos se detenham em uma disciplina de referência ( e não mais nas disciplinas de conteúdo mais genérico, como os livros de leitura), que possui suas próprias finalidades, seus conteúdos de ensino e seus métodos de aprendizagem específicos ${ }^{168}$. Decorre daí uma aproximação dos estudos sobre os livros didáticos com os da história das disciplinas.

André Chervel, ao indicar alguns caminhos possíveis para o desenvolvimento da História das disciplinas, observa que o estudo dos conteúdos escolares, bem como das atividades praticadas no cotidiano escolar, são fontes importantes para esse desenvolvimento. Os livros didáticos, nesse sentido, parecem recursos especialmente valiosos, uma vez que eles apresentam os conteúdos, organizados segundo alguns pressupostos pedagógicos, e em geral são acompanhados de exercícios que visam consolidar a aprendizagem. Por meio deles também é

165 Citando Chris Stray, Choppin afirma que "o livro didático é um produto cultural complexo...[que] se situa no cruzamento da cultura, da pedagogia, da produção editorial e da sociedade. Choppin, A . idem. p. 563.

166 Como observa Marisa Lajolo, mais do que propriamente lido, os manuais escolares são manipulados, de modo sistemático, em diversas situações de ensino e aprendizagem, tanto de modo individual como coletivo. O "uso" do livro didático é portanto muito mais variado do que a mera leitura, em que cabe ao leitor "colher as idéias (mais ou menos) perfeitas [...] ". Cf. Munakata, K. Op. cit. pp. 6 -7. Choppin, A . "História dos livros e das edições didáticas: sobre o estado da arte". Op cit. p. 565.

168 Idem, p. 558. 
possível identificar algumas das tradições pedagógicas e didáticas que esses livros ajudam a difundir entre os professores, que, por sua vez, as realimentam.

No âmbito da história do ensino de História, Circe Bittencourt demonstrou exemplarmente essa possibilidade quando analisou livros didáticos utilizados no Brasil no final do século XIX e início do XX. Entre muitos outros aspectos, ela demonstrou como no último quartel do século XIX verificou-se a substituição do tradicional modelo catequético dos manuais de História (estruturado a partir de perguntas e respostas) por um outro, estruturado em um texto sobre determinado tema seguido por um questionário (exercícios de fixação), ao mesmo tempo que uma concepção de história religiosa dava lugar a outra, laica. Esse novo modelo teve grande aceitação entre os professores, redundando em grandes vendagens e, com algumas variações, ainda hoje é encontrado em muitos livros ${ }^{169}$.

Situações de reformas educacionais e/ou curriculares constituem momentos especialmente interessantes de estudo, pois pode-se verificar em que medida disposições tomadas desde cima do sistema educacional - que definem os saberes a serem ensinados - ganham o plano da prática, introduzindo, ou não, mudanças e inovações efetivas nas práticas escolares, alterando, assim, os saberes ensinados e os saberes aprendidos ${ }^{170}$. O mesmo autor observa que a cada época vigora uma "vulgata", ou seja, a cada época o ensino de uma disciplina constitui um corpo de saberes e práticas cuja difusão é generalizada em todo o sistema de ensino de um país. Essas vulgatas são muito parecidas, quando não idênticas, havendo mesmo plágios ${ }^{171}$. Apesar dessas vulgatas constituírem certos modelos, não se pode pensar que eles se cristalizam, a ponto de se perenizarem. Ao contrário, em certo momento, diferentes circunstâncias podem fazer com que uma "obra inovadora" seja publicada, sendo gradativamente adotada por número crescente de professores. Vai se estabelecendo, então, um novo modelo para essas vulgatas.

169 No âmbito de outras disciplinas, podemos citar os trabalhos de Razzini, Márcia de Paulo G. 0 espelho da Nação: a Antologia Nacional e o ensino de português e literatura. Universidade Estadual de Campinas, 2000, Tese de doutoramento, em que a autora, estudando sucessivas edições da Antologia Nacional identificou $m$ conjunto de textos e excertos literários que gerações e gerações de secundaristas brasileiros estudaram; e Valente, Wagner. Uma História da Matemática Escolar no Brasil (1730 - 1930). São Paulo: Annablume, 1999, que analisa, desde uma perspectiva da longa duração, como foram se constituindo os saberes próprios à Matemática na escola.

171 Idem, p. 203. 
A pesquisa que realizamos possibilitou a verificação de como as vulgatas chegam a ter abrangência para além das fronteiras nacionais, podendo-se encontrar obras de mais de um país que seguem o mesmo modelo. Cuesta Fernandez chama esses modelos de códigos disciplinares, pois eles fornecem paradigmas estruturantes para uma disciplina escolar. A disseminação desses códigos pode se explicar por vários motivos. No caso específico de História, sabemos a força que representou o modelo francês na estruturação educacional em geral e dessa disciplina em particular, forjando uma certa organização programática que ainda hoje é percebida ${ }^{172}$. De outro lado, na medida em que os debates educacionais assumem caráter internacional, favorecidos ainda pelos meios eletrônicos de circulação de informação, novas propostas, surgidas em um país, podem ser rapidamente apropriadas ou adaptadas em outros. A questão que se põe é até que ponto essas inovações preservam, no fundo, antigas tradições ou, de fato, promovem rupturas ou pelo menos tentativas dela. Sabemos o quanto a escola e as práticas escolares tendem à preservação de tradições, mas ela está longe de ser algo petrificado; no entanto, nem sempre os que estão fora dela se dão conta disso e muitos continuam considerando a escola como local da inércia. Um exemplo clássico é a recorrente caracterização, no senso comum, de que o ensino de História continua assentado na memorização de grandes fatos e seus heróis. Ainda que se possa encontrar professores presos a essa concepção, ela está longe de constituir a única realidade encontrada nas salas de aula brasileiras.

\section{AS PESQUISAS SOBRE LIVROS DIDÁTICOS NO MÉXICO, ARGENTINA E BRASIL}

Os artigos de Graziela Batalla, Manuel Somoza e Kazumi Munakata reunidos no livro Los Manuales escolares como fuente para la Historia de la Educación en América Latina informam que os livros didáticos só recentemente passaram a ser tomados de modo mais sistemático como fontes de investigação nos três países em tela. A primeira autora, analisando a produção acadêmica entre as décadas de 1960 e 1990 no México, afirma que no âmbito da História da Educação, sobretudo desde uma perspectiva da história social da educação, as pesquisas ainda eram

172 O estudo de Evelyne Hery nos fornece uma visão ao mesmo tempo profunda e abrangente da história dessa disciplina escolar na França, enquanto diversos autores já apontaram a influência francesa na constituição da mesma disciplina na escola brasileira, como por exemplo Circe Bittencourt em sua tese de doutoramento, obra mencionada anteriormente. Hery, Evelyne. Un siècle de leçons d'histoire. L'histoire enseignée ao lycée 1870 - 1970. Rennes: Presses Universitaires de Rennes, 1999. 
muito incipientes. Os estudos pioneiros foram realizados entre os anos 1970 e $1980^{173}$ e somente na década seguinte se intensificaram, surgindo alguns centros de pesquisa tanto na capital do país como em outras cidades. A maior parte desses estudos privilegiou o viés da análise ideológica dos conteúdos, razão pela qual os livros de História, Geografia e Civismo foram os mais analisados. Contudo, nenhum deles dedicou-se ao estudo de obras destinadas aos alunos do bachillerato $^{174}$. É interessante mencionar que dois estudos preocuparam-se com temáticas relacionadas aos Estados Unidos: um analisou os conteúdos relativos à história daquele país em livros mexicanos e outro procurou verificar como eram tratados os temas da história do México nos livros norte-americanos ${ }^{175}$.

No levantamento por nós realizado em dezembro de 2003 na UNAM, na Universidade Nacional Pedagógica e no Colégio de México contatamos que nos anos anteriores tinham aumentado substancialmente o número de trabalhos em torno dos livros didáticos de História, especialmente no tocante aos aspectos metodológicos e da aprendizagem, alguns deles desenvolvidos sob a orientação de professores ligados à Psicologia da aprendizagem. No entanto, continuavam inexistindo pesquisas sobre o bachillerato.

$\mathrm{Na}$ Argentina, a situação era diversa. Miguel Somoza contabilizou em seu levantamento bibliográfico 115 obras cujas temáticas ligavam-se aos livros didáticos. Também se notou um predomínio nos estudos a partir de obras de História e leitura, não havendo, contudo, menção a trabalhos sobre livros de História para o nível médio. Um dos trabalhos que ele identificou, publicado em 1998, foi realizado por Luciano de Privitellio ${ }^{176}$, um dos autores de uma das obras que analisamos, o que reforça não só os indícios do trânsito de professores da academia e a produção editorial argentina como mostra que alguns autores têm os manuais escolares como seu objeto de investigação. Em nossa pesquisa bibliográfica, realizada na Faculdad Latinoamericana de Ciencias Sociales -

173 Curiosamente, a investigadora que mais trabalhos realizou nessa época, Zoraida Vázquez, é ela própria importante autora de livros didáticos para os três níveis de ensino, dedicando especial atenção à questão do nacionalismo e educação no México. Cf.Guzmán Batalla, Graciela."Consideraciones en torno al desarrollo de la investigacón histórica sobre los libros de texto en México, 1970 -1995". In Ossenbach, Gabriela e Somoza, Miguel (eds). Los manuales escolares como fuente para la História de la Educación en América Latinal. Madrid: Universidade Nacional de Educacióna Distancia, 2001, p. 52.

174 Batalla, G. Op. cit. p. 59

175 Idem, p. 60.

176 Privitellio, L. " Los otros en la historia escolar: las naciones estranjeras en los manuales de historia argentina entre 1956 e 1989." Buenos Aires: Entrepasados, no. 15, 1998. 
FLACSO, e na Universidade de Buenos Aires ${ }^{177}$, não conseguimos também identificar nenhum estudo sobre livros didáticos de História para o nível médio.

Graciela Carbone publicou em 2003 uma importante obra sobre os manuais argentinos, revelando os avanços do campo naquele país. Ela também enfatiza a predominância das análises ideológicas, mas aponta para abordagens inovadoras surgidas a partir dos anos 1980 em centros como a FLACSO e a Universidade Nacional de Luján, o que tem proporcionado uma reflexão mais consistente sobre tais objetos ${ }^{178}$.

Já Kazumi Munakata, ao realizar um primeiro balanço da produção brasileira em 1997, chegou a um número ligeiramente maior que o da Argentina. Em um novo balanço bibliográfico realizado em 2003, o mesmo autor constatou um expressivo aumento no número de trabalho a partir dos anos 1990 e, tal como Choppin, constatou a grande dispersão deles ${ }^{179}$. Tal ampliação vem sendo favorecida nos últimos anos pela formação de centros de pesquisa congregando numerosos participantes, como são os casos do grupo LIVRES, organizado a partir do Centro de Memória da Educação Escolar da Universidade de São Paulo ${ }^{180}$, em São Paulo e do Centro de Alfabetização, Leitura e Escrita (CEALE), da Universidade Federal de Minas Gerais, em Belo Horizonte. Munakata observava que naquela época grande parte das pesquisas desenvolviam-se de modo isolado, razão pela qual muitas vezes se ressentiam da falta de uma bibliografia de embasamento mais consistente e desconheciam a produção na área.

O autor não comenta que, apesar da ampliação do número de pesquisas, elas ainda privilegiam as séries que hoje integram o Ensino Fundamental. No tocante ao Ensino Médio, registre-se, continuam muito escassos os trabalhos de

177 É preciso admitir que o curtíssimo tempo que dispúnhamos para realizar tal levantamento provavelmente comprometeu o seu resultado, agravado pelo fato de que na UBA não havia fichários digitalizados, tornando a pesquisa praticamente inviável.

178 Carbone, G. Libros escolares una intreducción a su análisis y evaluación. Buenos Aires: Fondo de Cultura Económica de Argentina, 2003, pp. 76-85.

179 Munakata, K. Op. cit. p.1.

180 No grupo LIVRES, que entre outras tarefas dedica-se à constituição de um banco de dados disponibilizado on line sobre a produção editorial didática brasileira desde o século XIX até os anos 1990, encontram-se pesquisadores de quase todas as disciplinas escolares, que promovem discussões inter e transdisciplinares. Para maiores informações consulte www..paje.fe.usp.br/estrutura/livres/index.htm. 
investigação, e em nosso levantamento não conseguimos localizar nenhum que tivesse os livros de História para esse nível escolar como objeto específico ${ }^{181}$.

Munakata identifica na mesma publicação um alargamento das perspectivas analíticas $^{182}$. Durante os anos 70 e 80 , os livros didáticos eram objetos culturais muito desprestigiados, chegando mesmo a ser um tabu tomá-los como objeto de investigação. Havia enorme desconfiança sobre a possibilidade de se realizar um estudo sério sobre educação, tomando por base um objeto tão estigmatizado. Ainda assim, e talvez para demonstrar que os pesquisadores não tinham se "contaminado" por tão "perniciosos objetos", começaram a ser feitos estudos em que os livros didáticos invariavelmente eram tomados como veículos de difusão da ideologia dominante, o que reforçava os estigmas. Na esteira dos livros Mentiras que parecem verdades, de Humberto Eco e Marisa Bonazzi, e A manipulação da história no ensino e nos meios de comunicação, de Marc Ferro, produziram-se várias obras que, no dizer de Munakata, resultaram no gênero literário "Belas Mentiras":

Uma série de pesquisas acadêmicas dedicaram-se a flagrar nos livros didáticos e paradidáticos brasileiros a presença insidiosa da mentira, da manipulação, do preconceito, da mistificação, da legitimação, da dominação e da exploração burguesas - em suma, da ideologia [...]. Certamente, esse gênero literário nutriu-se de uma conjuntura política em que, para muitos setores da sociedade brasileira, era fundamental a crítica ao regime militar e seus "entulhos autoritários" (como se dizia à época). Livro didático (e paradidático) era

181 Encontramos em nosso levantamento alguns trabalhos sobre o ensino secundário, como são os casos de Arlette Gasparello Conhecimento histórico e ensino de História: a produção de conhecimento histórico escolar. São Paulo: Iglu, 2004 e Circe Bittencour em Pátria civilização e trabalho: o ensino de História nas escolas paulistas 1917 -1939. Entretanto, o ensino secundário brasileiro, nomenclatura que correspondia aos antigos ginásio e colegial, possuía características bastante distintas do que chamamos hoje de Ensino Médio, além do que era extremamente diminuta a parcela de jovens que a cursava. Mais recentemente, Décio Gatti publicou um livro, resultado de sua pesquisa de doutoramento, em que ele procurou analisar diversos aspectos da produção didática em História entre os anos 1970 e 1990, incluindo-se livros para o Ensino Médio. No entanto, sua abordagem é bastante distinta daquela que nos propomos. Gatti, Décio. A escrita escolar de História: Livro Didático e ensino no Brasil. Bauru/Uberlância: EDUSC/EDUFU, 2004. 
compreensivelmente objeto de suspeição, do mesmo modo que era suspeita - e não sem razão - , toda a organização escolar consolidada pela ditadura ${ }^{183}$.

Esse momento coincidiu com uma luta muito particular dos historiadores e geógrafos: a eliminação de Estudos Sociais dos currículos escolares, reintroduzindo-se as disciplinas de História e Geografia, uma vez que, desde 1971, a famigerada lei 5692 havia promovido importantes mudanças no sistema escolar brasileiro, entre elas a substituição dessas duas disciplinas no ensino de $1^{\circ}$. grau. Portanto, no caso de História, o combate contra as "belas mentiras" era duplo: político e ideológico. Não é desprezível a quantidade de textos publicados em torno dessa questão. Jaime Cordeiro contabilizou trezes deles, a maioria dos quais realizava uma "análise ideológica, examinando os seus textos quanto à consistência teórica e aos conteúdos veiculados"184.

Essa moda começou a refluir quando os pesquisadores passaram a dar maior ênfase à questão da defasagem entre os conteúdos escolares e as investigações acadêmicas. Alguns desses estudos denunciavam que os autores dos livros didáticos desconheciam ou desconsideravam as novas contribuições de uma historiografia renovada pelas novas abordagens, novos temas e novos problemas. Partiam do pressuposto de que há, ou deve haver, uma conexão direta e imediata entre a pesquisa acadêmica e o saber escolar e que a não incorporação dos novos estudos era sinal do tradicionalismo desses autores, apegados a uma "história oficial" ou, na melhor das hipóteses, a concepções "ultrapassadas". Outros,apontavam em direção contrária. É o caso de Selva Fonseca ${ }^{185}$, que constatava como, estimulada pela industria cultural, da qual o setor editorial é parte, o meio acadêmico se fazia cada vez mais presente na produção de obras didáticas e/ou de divulgação para um público mais amplo, nas quais se verificavam novas temáticas e abordagens. No dizer da autora "A nova produção historiográfica, abordando temas até então pouco estudados, tornou-se mercadoria de fácil aceitação no mercado de livros" ${ }^{186}$.

183 Munakata, Kazumi. "Histórias que os livros didáticos contam, depois que acabou a ditadura no Brasil".In: Freitas, Marcos Cezar. Historiografia brasileira em perspectiva. São Paulo: Contexto, 2001, p. 271.

185 Fonseca, Selva G. Os caminhos da História ensinada. Campinas: Papirus, 1993.

186 Idem, p. 145. 
De fato, o mercado editorial brasileiro expandiu-se de modo expressivo nessa época. Mas, ao contrário do que dá a entender essa mesma autora, a participação de cada empresa nesse mercado não dependia apenas do apoio do Estado, sobretudo por meio de compra de livros ou mesmo de financiamentos governamentais. Tornou-se cada vez mais importante para elas produzir obras que atendessem as necessidades dos professores, pois seria assim que assegurariam lucros crescentes. Daí porque as editoras desenvolveram novos produtos, acompanhados dos mais variados complementos, objetivando conquistar parcela maior de adoções. Não se tratava de estratégia "visando à aceitação maior do livro didático", como justifica Selva Fonseca ${ }^{187}$, já que essa modalidade de livro há muito fazia parte das práticas escolares brasileiras, mas para alcançar maior participação nas vendagens, oferecendo-Ihes "serviços" como por exemplo o planejamento anual pronto. O fato é que são visíveis nos últimos anos as mudanças tanto nos livros didáticos de História como nas análises que deles são feitas. Nosso propósito com esse trabalho, como dissemos, foi o de ampliar a compreensão sobre as obras para o nível médio, até agora pouco estudadas.

\section{OS LIVROS, OS AUTORES E AS EQUIPES EDITORIAIS}

Dissemos anteriormente que concebemos os livros didáticos como obras necessariamente coletivas, caráter que se acentuou ainda mais nos últimos anos. Para efeito de nossa exposição, porém, chamaremos de autores aqueles que assinam a obra, sabendo que uma equipe editorial produziu os volumes. Iniciaremos, pois, nossa análise pela caracterização das equipes que desenvolveram cada uma das obras selecionadas. Recordemos quais são elas:

Obras mexicanas:

- Historia Universal, de Marialba Pastor. Editora Santillana.

- Historia Universal, de Julieta Pérez, Geraldo Lara e Manuel Romero. Editora Oxford.

Obras argentinas:

- Historia Mundial Contemporânea, de Marisa Alonso, José Benclowicz, Maria Bouzigues, Carolina González Velasco, Karin Grammático, Melina 
Piglia, Valeria Pita, Marta Poggi, Claudia Toouris e Silvia Valle. Editorial Porto de Palos.

- Historia del Mundo Contemporâneo - Desde la "doble revolución" hasta nuestros dias, de Luciano de Privitellio, Lucas J. Luchilo, Silvina I. Montenegro, Liliana Cattáneo, Alejandro Cataruzza. Editora Santillana.

Obras brasileiras

- História - Das Cavernas ao Terceiro Milênio, de Myriam Becho Mota e Patrícia Ramos Braick. Editora Moderna ${ }^{188}$.

- História para o Ensino Médio - História Geral e do Braasil, de Cláudio Vicentino e Gianpaolo Dorigo. Editora Scipione.

O primeiro ponto a observar é que só Marialba Pastor assina sozinha sua obra; todas as demais tem dois ou mais autores, chegando, nos casos das duas obras argentinas, a uma equipe de autores 5 autores e outra com 9 membros. Os dois livros brasileiros foram escritos por uma dupla, enquanto outro volume mexicano contou com um trio de autores. Portanto, sob esse aspecto, verificam-se configurações bastante variadas.

Todos os autores são, ou foram, professores, atuando no próprio segmento do nível médio ou como professores universitários. Marialba Pastor é professora de História na Faculdade de Filosofia e Letras da UNAM, e, o quanto pude saber, nunca atuou no nível médio. Sua formação inicial foi em Ciências Sociais, mas seu mestrado e doutorado foram na área de História. Essa obra foi a primeira que escreveu para o segmento escolar. Claúdio Vicentino é autor de livros didáticos desde 1995. Ele assina outras obras tanto para o Ensino Fundamental como para o Ensino Médio, tanto didáticas como paradidáticas, sempre pela Editora Scipione. Pela página de rosto sabemos que ele é bacharel e licenciado em Ciências Sociais pela USP e pós-graduado em História pela UnB. Sabemos também que ele e seu co-autor atuaram como professores do Ensino Médio e prévestibulares. Gianpaolo Dorigo é licenciado e bacharel em História pela mesma USP, sendo autor de um livro didático de História do Brasil para o Ensino Médio, publicado igualmente pela Scipione. 
Myriam Motta é apresentada na página de rosto do livro como Master of Arts - Ohio University - Athens, EUA e como professora do Ensino Médio e Superior em Itabira, Minas Gerais. Patrícia Braick aparece como mestre em História das Sociedades Ibero-Americanas e Brasileira pela PUC do Rio Grande do Sul, atuando como professora do Ensino Médio em Belo Horizonte.

Os quatro autores brasileiros, portanto, procuram credenciar-se enquanto tal tanto por sua formação acadêmica como pela experiência no magistério.

No caso do livro assinado pelos três autores mexicanos, abaixo do nome de cada um deles vem a referência Universidade Nacional Autônoma do México. Foi lá que se formaram e onde atuam como professores ligados à Faculdade de Filosofia e Letras e ao curso de bachillerato. Essa obra é a primeira que escreveram destinada ao público escolar, tomando por base sua experiência em sala de aula.

No livro História Mundial Contemporánea também se vê na página de rosto referências aos autores. Marisa Alonso é apresentada como Profesora de Enseñanza Normal y Superior (UBA) em História e especialista em didática (UBA), enquanto outras duas autoras (Maria Bouzigues e Claudia Touris) são apresentadas como Profesoras de Enseñanza Secundária, Normal Y Especial em História, com a diferença que a primeira pela UBA e a segunda pela USAL. Outras duas (Valeia Pita ${ }^{189}$ e Silvia Vale) aparecem como Profesoras de Enseñanza Media y Superior em História pela UBA.. Marta Poggi é apresentada como Profesoras de Ensñanza Secundária en Historia (I.N.S.P. Joaquín Gonzáles). Os outros quatro autores - José Benclowicz, Carolina Velasco, Karin Grammátio e Helena Piglia aparecem apenas como professores de História.

O livro publicado pela Santillana da Argentina não dá as credenciais dos autores, mas contém uma outra importante informação sobre a equipe responsável pela obra:

189 Na página de crédito lemos que Valéria Pita também atuou no copidesque, juntamente com Fernando Pozos. 
Historia del mundo contemporáneo es una obra colectiva criada y diseñada en el Departamento Editorial de Ediciones Santillana, bajo la dirección de Herminia Mérega, por seguinte equipo:

Luciano de Privitellio, Lucas J. Luchilo, Silvana I. Montenegro, Liliana Cattáneo, Alejandro Cattaruzza.

Editora Senior: Amanda Celotto

Subdirectora editorial: Lidia Mazzalomo

El Proyecto de Investigación ${ }^{190}$ es una colaboración del Departamento Editorial

No caso desse livro, fica evidenciado na página de rosto o que em outras obras só se percebe pela página de créditos: a obra foi concebida e desenvolvida por uma equipe de oito pessoas diretamente ligadas a essa tarefa, cabendo a direção do projeto a editores da própria Santillana, além de uma equipe de produção editorial, composta de dois diagramadores, um cartógrafo, uma revisora e seis pessoas que cuidaram da iconografia, todas aparentemente sob comando de um gerente de produção. Registre-se, pois, que nesse caso, a editora explicita não só que o projeto editorial é seu, bem como a direção de seu desenvolvimento, cabendo aos autores a sua execução. Mesmo podendo interferir nesse projeto, ele está filiado a um empreendimento maior, que visa oferecer obras para todas as disciplinas do curso Polimodal, dentro de uma mesma proposta editorial/pedagógica ${ }^{191}$.

Analisando as páginas de crédito dos demais volumes, constatamos que, com exceção do livro publicado pela Oxford, todos os livros contaram com o trabalho de pelo menos 15 pessoas, chegando em três casos a mais de $20^{192}$. Kazumi Munakata explicou com clareza as mudanças tecnológicas e mercadológicas que levaram os trabalhos editoriais, no Brasil, serem desempenhados por uma numerosa equipe de profissionais, daí resultando uma

Trata-se de um complemento da obra, apresentado ao final do volume.

191 Essa é uma prática comum da Editora Santillana. No Brasil, as coleções Pitanguá e Araribá, destinadas ao Ensino Fundamental, seguem proposta semelhante.

192 A página de créditos do livro da Oxford menciona apenas o nome de seis pessoas. Reiteramos que, no Brasil, foi especialmente a partir dos anos 90 que as equipes editoriais se tornaram maiores, envolvendo técnicos executores de diversas tarefas. Para maiores informações a esse respeito ver Munakata, Kazumi. Produzindo livros didáticos e paradidáticos. Pontifícia Universidade Católica de São Paulo - Programa de Estudos Pós-Graduados em Educação, 1997. Tese de doutoramento. 
produção industrial de caráter técnico bastante complexo. Por essas páginas de crédito, podemos acreditar que também no México e na Argentina ocorreram processos semelhantes.

Leitores críticos e consultores são freqüentemente acionados para avaliarem a obra durante o seu desenvolvimento ${ }^{193}$; pesquisadores iconográficos, cartógrafos, equipes de tratamento de imagens, ilustradores e chefes de arte zelam pelos aspectos visuais. Editores e revisores, muitas vezes com o apoio de copidesques, realizam um trabalho mais específico com o próprio texto. Ainda que em graus diferentes, todos interferem no resultado final e, por conseqüência, na recepção do livro por parte dos professores e dos alunos.

Um último aspecto que vale a pena mencionar é o número das edições dos volumes que dispomos. O exemplar da Editora Oxford é da primeira edição, feita em 2003, enquanto o livro de Marialba Pastor teve uma segunda edição no ano 2000 e quatro reimpressões: setembro de $2002^{194}$, junho de 2003, junho de 2003 e agosto de 2003, revelando a boa aceitação da obra entre o público. O livro da Puerto de Palos teve sua primeira impressão em 2002, data do exemplar que dispomos. O livro da Santillana é mais antigo, datado de 1998, mas a nota sobre a aprovação dos mapas por parte do governo argentino informa que ela ocorreu em 1999, sendo sua primeira edição de janeiro daquele ano e a quarta ocorrida em janeiro de 2002, o que faz supor que tenha ocorrido uma reimpressão por ano. 0 livro da Editora Moderna foi lançado em 2002, ano do exemplar que utilizamos, e o livro da Editora Scipione foi editado em 2001.

\subsection{Os livros em seus aspectos físicos}

A tabela a seguir nos possibilita verificar as principais características físicas das obras analisadas:

193 No livro da Scipione há menção a vários colaboradores que contribuíram para o desenvolvimento da obra tanto no tocante aos conteúdos historiográficos como técnicos, referentes à parte da pré-história, aos quais os autores agradecem.

194 Vale lembrar que o ano letivo no México começa em setembro. 
Tabela 1

\begin{tabular}{|c|c|c|c|c|c|c|c|c|}
\hline Países & Editoria & Obra & $\begin{array}{c}\mathrm{N}^{\circ} \text { de } \\
\text { páginas }\end{array}$ & $\begin{array}{c}\mathrm{N}^{\circ} \mathrm{de} \\
\text { imagens }\end{array}$ & $\begin{array}{l}\mathrm{N}^{\circ} \text { de } \\
\text { mapas }\end{array}$ & $\begin{array}{c}\text { Tipo } \\
\text { de } \\
\text { papel }\end{array}$ & Impressão & Formato \\
\hline Brasil & Scipione & $\begin{array}{l}\text { Das cavernas ao } \\
\text { Terceiro Milênio }\end{array}$ & 688 & 442 & 77 & Off-set & 4 cores & $19,5 \times 26$ \\
\hline Brasil & Moderna & $\begin{array}{l}\text { História para o } \\
\text { Ensino Médio }\end{array}$ & 592 & 354 & 75 & Off-set & 4 cores & $20 \times 27,5$ \\
\hline Argentina & $\begin{array}{l}\text { Puerto de } \\
\text { Palos }\end{array}$ & $\begin{array}{l}\text { Historia Mundial } \\
\text { Contemporánea }\end{array}$ & 384 & 624 & 29 & Couchê & 4 cores & $19,5 \times 26$ \\
\hline Argentina & Santillana & $\begin{array}{l}\text { Historia del mundo } \\
\text { contemporáneo }\end{array}$ & 351 & 407 & 26 & Couchê & 4 cores* & $21 \times 27$ \\
\hline México & Oxford & Historia Universal & 318 & 112 & 32 & Off-set & 2 cores $^{\star \star}$ & $19 \times 23,5$ \\
\hline México & Santillana & $\begin{array}{c}\text { Historia Universal } \\
\text { Bachillerato }\end{array}$ & 304 & 361 & 43 & Couchê & 4 cores & $19 \times 26$ \\
\hline
\end{tabular}

* impresso na Colômbia

** impresso em azul e mostarda (pantone)

Como os livros brasileiros compreendem conteúdos para três anos e contemplam a História Geral desde a Pré-História, o número de páginas e de mapas é expressivamente maior, o que já não ocorre com relação ao número de imagens, revelando como sob esse aspecto as obras argentinas se sobressaem pela farta iconografia, valorizada ainda mais pela impressão feita em papel couchê, que assegura melhor resultado gráfico e visual. Por outro lado, é notória a simplicidade gráfica da obra da Editora Oxford, o que indica a preocupação dos editores em produzir uma obra de custos mais baixos. É no quesito formato em que as obras apresentam as menores diferenças.

Quando estabelecemos a relação entre número de imagens por páginas ficam ainda mais evidenciadas as diferenças apresentadas pelas duas obras argentinas: 
Tabela 2

\begin{tabular}{|c|c|c|c|}
\hline Obra & $\begin{array}{c}\text { No. de } \\
\text { páginas }\end{array}$ & $\begin{array}{c}\text { No de } \\
\text { imagens }\end{array}$ & Proporção \\
\hline Scipione & 688 & 442 & 0,66 \\
\hline $\begin{array}{c}\text { Moderna } \\
\text { Puerto de }\end{array}$ & 592 & 354 & 0,59 \\
\hline $\begin{array}{c}\text { Santillana } \\
\text { Argentina }\end{array}$ & 351 & 407 & 1,15 \\
\hline Oxford & 318 & 112 & 0.35 \\
\hline $\begin{array}{c}\text { Santillana } \\
\text { Mexico }\end{array}$ & 304 & 361 & 1,18 \\
\hline
\end{tabular}

Essas diferenças expressivas apresentadas pelos livros argentinos e pelo mexicano produzido pela Santillana acarretam custos bem mais elevados, o que parece ter sido compensada pelas grandes tiragens, resultado da liderança de vendas. Por outro lado, isso reforça a crença de que os aspectos visuais são bastante valorizados pelos professores, razão pela qual as editoras fazem pesados investimentos em seus produtos nesse quesito.

No caso dos dois livros brasileiros, percebe-se um predomínio da área tomada pelos textos, o que se acentua quando percebemos que seus projetos gráficos reservam poucas áreas para o chamado descanso visual (áreas em branco) e o tamanho em que as imagens são reproduzidas. Sob esses dois aspectos, a obra da Santillana Argentina se destaca claramente de todas as demais, uma vez que, além de elevado número de imagens, a maioria delas foi reproduzida em tamanho grande.

Um outro aspecto que comparamos, ainda que não estejam presentes em todas as obras, foram as tabelas, os gráficos e os esquemas: 
Tabela 3

\begin{tabular}{|c|c|c|c|}
\hline $\begin{array}{c}\text { Editora da } \\
\text { Obra }\end{array}$ & Tabelas & Gráficos & Esquemas \\
\hline Scipione & 6 & 22 & 49 \\
\hline Moderna & 19 & 15 & - \\
\hline $\begin{array}{c}\text { Puerto de } \\
\text { Palos }\end{array}$ & 15 & 21 & 5 \\
\hline $\begin{array}{c}\text { Santillana } \\
\text { Argentina }\end{array}$ & 18 & 10 & 6 \\
\hline
\end{tabular}

Aqui também se observam significativas variações, denotando a importância dada pelos autores a outras modalidades de linguagem, bastante comuns no diaa-dia, mas que nem sempre o aluno é capaz de compreendê-la, por não ser devidamente orientado.

No tocante ao tipo de letra utilizado (fontes), os dois livros mexicanos usam tipos serifados. Há partes em que se usa fonte sem serifa, como os boxes, legendas e atividades. Já os dois livros brasileiros foram compostos com letras sem serifa. Dos seis livros, um de cada país traz o texto em duas colunas: o das Editoras Moderna, Oxford e Santillana argentina ${ }^{195}$. No caso do livro da Santillana Mexicana e da Puerto de Palos, a coluna única foi diagramada ocupando mais a parte interna do livro, do que resulta uma falsa coluna, onde foram aplicadas as imagens e os boxes.

\subsection{Da capa para o miolo}

As capas dos seis livros foram desenvolvidas a partir de conceitos bem diferentes. O livro de Marialba Pastor reproduz o quadro de Edvard Munch O grito, sobre o qual se aplica a titulagem. O predomínio do tom vermelho torna a capa chamativa e vibrante, o que, no nosso entender, contrasta com a proposta da obra, mais sóbria.

195 No livro da Puerto de Palos, a seção La vida cotidiana também foi diagramada em duas colunas. 
Os dois livros brasileiros têm capas que mostram um conjunto de imagens que nos reportam ao passado, com a diferença de que na capa desenvolvida pela Editora Moderna toda a área é ocupada por um grande número delas, enquanto a Editora Scipione preferiu aplicar as sete figuras de modo mais disperso, deixando o fundo com uma cor mais rebaixada, como uma textura, o que dá mais leveza visual. Pode-se dizer que as capas têm identidade com os respectivos miolos, posto que no livro das duas autoras temos páginas densamente ocupadas, com a aplicação de muitos elementos gráficos, enquanto o livro dos dois autores é bem menos carregado, mas em ambos encontramos um mosaico de textos e imagens para cada um dos temas apresentados. Um conceito semelhante orientou o capista da outra obra mexicana, da Editora Oxford, que também aplicou três imagens (um castelo, um mapa-mundi antigo e uma foto de Gandhi) sobre fundo azulado.

A capa da editora Puerto de Palos é mais gráfica $^{196}$ : sobre uma foto mostrando a textura e os veios de uma madeira rústica, aplicou-se os títulos e uma foto do Arco do Triunfo. Note-se que não constam os nomes dos autores. Já a do livro da Santillana argentina é predominantemente preta. $\mathrm{O}$ nome dos autores é aplicado com letras vazadas (em branco), mas com destaque menor do que o título, em rosa forte, resultando grande contraste visual.
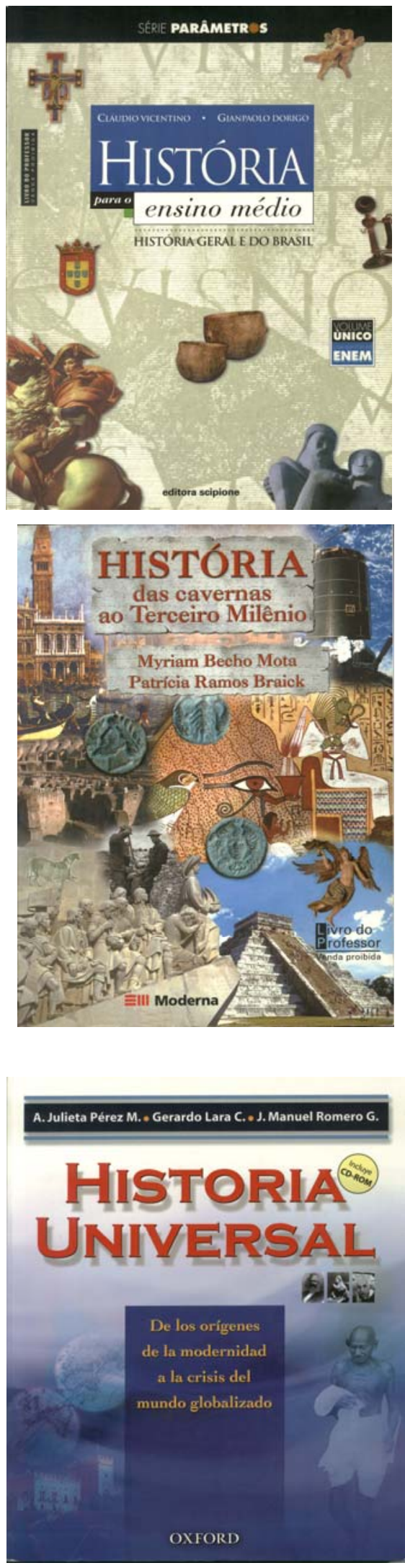

${ }^{196}$ Como esse volume é parte integrante de uma coleção que abarca todo o conjunto de disciplinas do Polimodal, a capa segue o mesmo padrão da coleção. 

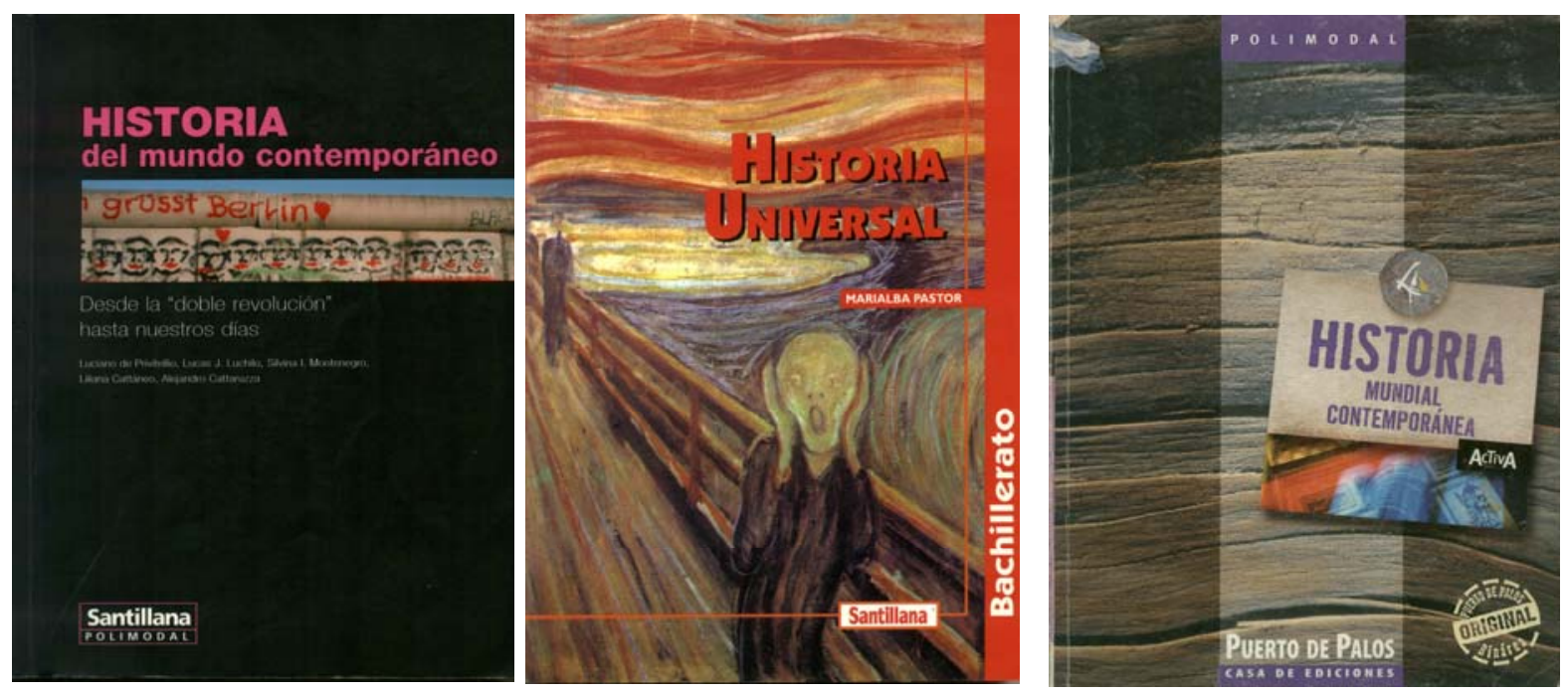

Passando para a parte interna do livro, o chamado miolo, os conteúdos abarcados pelos livros brasileiros, como já observamos, são temporalmente mais extensos, enquanto os livros mexicanos e argentinos se dedicam ao estudo da Idade Contemporânea, com a diferença que as obras mexicanas sempre trazem um capítulo introdutório, com conteúdos relativos à Idade Moderna. Se compararmos os sumários dos seis livros no que diz respeito aos conteúdos comuns a todos eles, constatamos muitas semelhanças: o século XIX é tratado de modo mais abrangente e mais rápido, enquanto o século XX corresponde sempre a mais da metade do volume ou da parte correspondente ao período contemporâneo. Em boa medida isso se explica porque os conteúdos referentes ao século XIX são normalmente apresentados por temas, como a Revolução Industrial e o surgimento do movimento operário, enquanto o século XX obedece a uma organização mais centrada em episódios ou períodos, como a I Guerra, o Entre-guerras e a Guerra Fria.

Podemos, assim, identificar um primeiro eixo comum aos seis livros: eles tomam o processo de consolidação e expansão capitalista e da ordem social burguesa como estruturantes da obra e por conseqüência do programa a ser desenvolvido em classe. Portanto, apesar dos títulos de todas as obras serem muito abrangentes, de fato o que se apresenta é uma história do capitalismo.

Os livros seguem uma organização dos conteúdos também bastante semelhante, quando analisamos aqueles relativos ao período contemporâneo: 
inicialmente se aborda a dupla revolução - a Francesa e a Industrial - que se encerra com a expansão imperialista e a I Grande Guerra; um segundo bloco temático envolve a I e a II Guerra Mundial, sendo que os dois conflitos merecem estudo relativamente detido nos livros mexicanos e argentinos. $O$ terceiro momento corresponde ao mundo bipolarizado instaurado com a Guerra Fria, cujo final, marcado pela queda do Muro de Berlim e plena vigência do mundo globalizado, dá início ao quarto e último bloco temático. Podemos identificar, então, um exemplo do que Chervel chama de vulgata, que nesse caso é internacional. Portanto, os antigos arranjos de conteúdo que privilegiavam os aspectos políticos ou mesmo da história das grandes civilizações deu lugar a um outro, mais marcadamente econômico.

Quase todos os livros se iniciam com uma unidade, ou pelo menos um capítulo, de introdução, em que são apresentados alguns conceitos básicos e os fundamentos da História. A exceção é o livro elaborado pela equipe de Marisa Alonso, que é também um dos dois únicos que não contam com um texto de apresentação da obra (o outro é o também argentino História Del mundo contemporâneo). Apesar dessas ausências, essas partes nos parecem relevantes, uma vez que nelas os autores expressam sua visão de história - ou aquela que gostariam de expressar - razão pela qual nos deteremos em analisá-las.

Em três apresentações, os autores preferiram encaminhar o texto aos professores, com o intuito de, primeiro, convence-los a adotar a obra e, depois, orientá-los em seu trabalho, fornecendo as linhas gerais da proposta que estrutura o livro. Vicentino e Dorigo, ao contrário, preferiram destina-lo aos alunos. Essa exceção parece-nos bastante interessante. Dizem eles:

Caro aluno,

Quando elaboramos esta obra, nós, autores, tínhamos em vista diversos objetivos. O primeiro deles era oferecer um livro que pudesse ajudá-lo a compreender a realidade em que vivemos.

Além disso, o livro deveria auxiliá-lo em seus estudos, não apenas na escola, no Exame Nacional do Ensino Médio (ENEM) ou nos vestibulares, mas também na eventual vivência universitária. Pretendíamos ainda mais: que os 
conhecimentos adquiridos nesse curso pudessem acompanhá-lo para além dele, no decorrer de sua vida de adulto atuante na sociedade.

Outra preocupação que tivemos foi a de que o livro pudesse ser utilizado por seu professor como um suporte e que fosse flexível, pronto para se adaptar a propostas de diferentes cursos. Acreditamos que um moderno curso de história envolve permanentes conexões com outras áreas do conhecimento e com nossas experiências cotidianas (que também são "multidisciplinares"), pois o conhecimento estanque se torna sem significado, vazio e, por isso, desinteressante. Por essa razão, nas páginas que seguem, você vai deparar com textos e atividades que propõem vínculos com literatura, arte, política e economia, por exemplo.

Finalmente, achamos importante que você perceba que a história, como área do conhecimento humano, não enuncia verdades prontas ou acabadas: a idéia de "conhecer o passado como ele realmente foi" simplesmente não existe. Pretendemos que você entenda e desvende como se constrói e constitui o próprio conhecimento histórico, que perguntas são feitas, que problemas ou limitações existem para os especialistas. Queremos que você compreenda a impossibilidade de existir conhecimento neutro em ciência.

O que conhecemos sobre o passado, portanto, é uma construção feita pelos estudiosos que, querendo ou não, refletem seus valores, projetam seus interesses, professam suas crenças.

Enfim, buscamos elaborar um manual de história centrado na própria história, na maneira como se chegou a esse acúmulo de conhecimentos, à diversidade dos olhares sobre o passado como estímulo para a reflexão, lembrando que o passado é, na realidade e sempre, um conjunto de interpretações.

Estão postos de maneira bastante clara os princípios orientadores dos autores: estuda-se história para a vida e esse estudo precisa fazer conexões com outras áreas do conhecimento, pois a realidade é interdisciplinar; a história é uma construção, carregada de valores e interesses, e que é sempre uma interpretação, podendo haver outras.

A questão que procuramos verificar é até que ponto tais princípios de fato estão subjacentes às unidades e aos capítulos, mesmo considerando as 
limitações inevitáveis, do número de páginas que o livro pode ter, o cronograma que ele precisa obedecer, dentre outros fatores. Depois de percorrer os inúmeros capítulos que compõem o volume, o que se constata é que as interpretações dos próprios autores não são apresentadas como apenas uma versão dos acontecimentos, podendo haver outras; tampouco os alunos são levados a perceber como o conhecimento histórico foi e é construído, exceto em alguns momentos - na seção denominada Bastidores da História - em que se tecem considerações dessa ordem, mas que assumem caráter "teórico", genérico e generalizante (por exemplo, ao classificar as versões da história entre vencedores e vencidos). Além disso, "compreender a realidade em que vivemos" resume-se de fato àquela relacionada com os centros mais dinâmicos do capitalismo, inclusive brasileiros, mas desconsidera, curiosamente, a possibilidade desse aluno ser um trabalhador integrado a essa dinâmica, situação, como vimos no capítulo anterior, vivida por muitos alunos. Há, assim, uma discrepância entre a história que se diz pretender ensinar e aquela que se apresenta de fato nas páginas do livro.

As duas autoras brasileiras, por seu turno, depois de citarem um trecho dos PCNs de História para o Ensino Médio, chamam atenção para o fato de o estudo da história contribuir para a construção de laços de identidade entre indivíduos que partilham um mesmo tempo e um mesmo espaço. Continuam elas:

Partindo de uma efetiva dimensão de contemporaneidade, utilizamos como eixo norteador deste trabalho a discussão do passado sob a luz do presente. Procuramos a todo instante mergulhar nos acontecimentos e nas ações do homem, nos quais o passado e o presente estão articulados no desafio à compreensão da História. Tal procedimento não tem a intenção de conceder, aos atores históricos do passado, sentimentos e ações gerados no presente, ou mesmo distorcer os acontecimentos da História, e sim a de levar o leitor a uma compreensão ativa da realidade social do Brasil e do mundo.

Sem entrar no mérito do que se pode entender por "partindo de uma efetiva dimensão de contemporaneidade", o que as autoras dizem é que procuraram não incorrer em anacronismos, fato bastante comum, sobretudo no plano do senso comum, quando se avalia uma situação do passado com olhos e referências do 
presente. O risco torna-se maior quando se pretende organizar o estudo do passado a partir de questões do presente. Além disso, o fato de se estabelecer permanentemente essa relação não é o suficiente para se assegurar uma "compreensão ativa da realidade". Mas ao chamarem atenção para esse ponto, elas visaram distinguir sua proposta metodológica de outras obras, ainda que ao final ressaltem que tal proposta não deve limitar o universo de professores e alunos usuários do seu livro, que pretende ser o mais amplo possível. Chegamos, então, a um dos pontos comuns às apresentações dos livros brasileiros: atender às mais variadas situações escolares brasileiras, o que, convenhamos, é desafio dos mais ambiciosos que se pode ter. Outro ponto, é a preocupação de preparar o aluno tanto para a vida adulta, como cidadãos, como para os exames do final do Ensino Médio, especialmente os vestibulares, e mesmo a vida universitária. Não por outro motivo, em ambos os livros encontramos blocos de questões retiradas de provas aplicadas nos mais variados estados. Foge aos propósitos de nossa pesquisa avaliar em que medida os conteúdos que compõem os dois livros brasileiros recobrem os programas dos exames vestibulares das maiores universidades brasileiras; de todo modo, não parece ser arriscado dizer que, por almejarem de alguma forma englobar "toda" a História, ambas as obras precisaram sacrificar alguns dos compromissos - especialmente os de ordem metodológica - assumidas no texto de apresentação. Reside exatamente nesse aspecto um dos maiores entraves para que os propósitos anunciados de início acabem sendo perdidos nas páginas que se seguem, como poderemos observar mais adiante.

A mexicana Marialba Pastor também utiliza o espaço da apresentação para externar sua concepção de história, o que serve para ela explicar a motivação que teve para escrever a obra. Inicialmente constata que freqüentemente os alunos se queixam que " ' la História es aburrida y no se le entendiende', que 'la Historia son solo nombres e fechas', que 'hay de leer mucho y no se aprende nada' ". Por isso, quando se pensou em escrever o livro (a autora não escreve na primeira pessoa, mas na forma impessoal, o que pode significar que o projeto editorial não é de fato seu, apenas ela foi convidada a escrevê-lo, segundo um modelo editorial recorrente da Santillana), levou-se em conta que muitos textos de História se limitam a dar uma ampla informação sobre os acontecimentos históricos, sem explicar de modo claro e suficiente por que eles sucederam daquela maneira. 
Esse seria o motivo pelo qual o estudo de história se torna tedioso, impedindo que os alunos tenham seu interesse e curiosidade despertados. Daí porque

[...] se tomó la decisión de que este libro se orientara, fundamentalmente, a explicar, a mostrar la importancia de lo ocurrido en el pasado, sin perder nunca de vista que, en última instancia, lo que más interesa a los seres humanos es compreender nuestra condición presente para orientarnos y tomar mejores decisiones.

Destaque-se, então, o propósito da autora de escrever uma obra que se distingue da maior parte das outras de seu país, porque, mais do que mero conjunto de informações, pretende explicar as causas dos acontecimentos históricos, pois é desse modo que fica evidenciada a importância do passado para a compreensão do presente. Continua a autora no texto de apresentação:

Vivimos en un mundo de crisis y incertidumbre. Todavia no se ha inventado la formula para solucionar, en corto plazo, los grandes problemas que padece actualmente la humanidade: el desempleo, el hambre, el desbordado crescimiento de la población, el deterioro del ambiente y la violencia. Pero la historia nos enseña que los seres humanos han atravesado por otras dramáticas situaciones de destrucción material y decepción moral, y que las han superado con éxito como, por ejemplo, le ocurrió a Europa después de la Segunda Guerra Mundial. También nos enseña que los seres humanos puedem errar y fracasar facilmente, sobre todo, cuando se impone la ignorancia, el fanatismo, el egoísmo u otros defectos.

Fica explícita a crença de que os grupos sociais do passado fizeram certas escolhas, cujos resultados podem variar entre o êxito e o fracasso, ainda que não se pergunte êxito e fracasso para quem. Portanto, a história é resultado de várias possibilidades que se apresentavam aos grupos humanos. Se assim se manifesta a autora, observamos no desenvolver da obra que essa concepção de história não continua prevalecendo, pois, ao se apresentar o trajeto percorrido pelas sociedades no passado, não são mostradas as alternativas, as possibilidades históricas que estavam em jogo, qual delas foi "a escolhida" e quem fez essa 
escolha. Observe-se ainda o componente moral e ético presente em sua argumentação.

La historia no se repite, pero ayuda a entender a los seres humanos: sus necesidades y deseos, sus ambiciones y limitaciones, sus ilusiones y realidades. Por ello, la historia es un asunto vivo, no un relato sobre muertos. Es una materia imprescindible para enfrentar com más responsabilidad, inteligencia y creatividad el presente, independientemente del oficio o profesión que se elija.

No parágrafo final afirma-se que o livro aborda os grandes fenômenos e processos ocorridos nos séculos XIX e XX no mundo, vale dizer, trata-se de um livro da História Contemporânea. Optou-se por contemplar aqueles fatos sem os quais não podemos compreender o mundo em que vivemos. Trata-se, indubitavelmente, apenas de uma síntese, pois tais acontecimentos poderiam ser apresentados de modo mais aprofundado ou extenso, incluindo-se muito mais dados do que nele se encontram. Assim, ela justifica as escolhas que teve de fazer ao elaborar a obra, contemplando certos tópicos e desprezando outros, acreditando que elas possibilitam alcançar

Los objectivos de poder escuchar y leer con conocimiento de causa las noticias internacionales, de empezar a tomar consciencia de los problemas actuales, de formarnos una primera opinión acerca de lo que seria conveniente evitar y enfrentarnos, con mejores armas, a los retos del futuro.

Evidencia-se, portanto, o caráter instrumental que se pretende dar ao curso de história proposto pela obra. Espera-se que, ao estudar as unidades e capítulos que se seguem, os alunos sejam capazes de entender o momento em que vivem, formando uma opinião. Ainda que seja pela omissão, conclui-se que não há grandes preocupações com questões relacionadas à aprendizagem, ficando o foco mais centrado no âmbito dos conhecimentos históricos em si mesmos. Fica implícito no texto que, por se tratar de um livro de História Universal, essa compreensão deve abarcar todo o mundo.

Um aspecto que chama atenção nessa autora é que ela não situa o conhecimento veiculado pelo livro dentro de um corpo de conhecimentos 
históricos maiores, muito menos considera sua apresentação como uma versão interpretativa sobre o passado, como fizeram os dois autores brasileiros na mesma página de apresentação. Resulta daí uma distinção profunda entre esse livro e todos os demais: essa autora concebe o conhecimento histórico como único, coeso e coerente. Não se fala em construção de conhecimento muito menos que os autores têm visões diferentes sobre o passado. No máximo, ela admite que conhecimentos novos podem ter superado os anteriores.

Julieta Pérez, Geraldo Lara e Manuel Romero - os outros autores mexicanos- procuram enfatizar no texto de apresentação a diferença do livro frente aos demais, o que é especialmente importante quando se está lançando uma nova obra no mercado. Pretendem mostrar o "processo histórico de maneira integrada, mostrando as relações, determinações e contradições entre os fenômenos econômicos, políticos, sociais e culturais". E fazem isso incorporando temáticas que têm ocupado os historiadores há tempos, mas que são encontrados muito escassamente nas obras didáticas para o bachillerato, como por exemplo a higiene a Idade Média, a vida de um adolescente no século XIX e a participação das mulheres em diferentes épocas.

Es interés central de los autores ofrecer un trabajo accesible y que a la vez contenga información amplia y profunda para el alumno de bachillerato, que o aproxime a la investigación en el campo de la História. También se busca coadyuvar en el desarrollo de la capacidad de análisis del joven, asi como de reflexión sobre los problemas que aquejan a la sociedad contemporánea, a través de una visión histórica, es decir, sus origenes y los cambios, de modo que pueda definir sus responsabilidades de manera consciente.

Considerações semelhantes são encontradas na apresentação dos dois livros brasileiros - mas não no de Marialba Pastor, com quem os outros autores mexicanos disputam mercado e a quem se dirige certamente a crítica quanto à abordagem histórica - indicando a preocupação deles em incorporar contribuições recentes do campo historiográfico. Como veremos, de fato há muitos indícios nos livros analisados que revelam a efetivação dessa preocupação. 


\section{INTRODUÇÃO AOS ESTUDOS HISTÓRICOS: COMEÇO OU RECOMEÇO?}

Marialba Pastor inicia a sua unidade introdutória tratando da utilidade da História, passando depois a caracterizar o trabalho do historiador, dizendo que esse sempre se coloca perguntas e problemas, a partir dos quais desenvolve suas investigações, fazendo uso de documentos. Complementa o tópico um boxe que ressalta a importância de Leopold von Ranke por introduzir novos métodos de trabalho histórico. Aprofundando a questão da construção do conhecimento histórico, a autora observa não ser possível formular leis históricas e que provas e explicações podem superar outras mais antigas. Os dois últimos tópicos destinamse à relação entre o passado, o presente e o futuro - congruente com sua visão de história, segundo a qual essa orienta as ações futuras - e às etapas históricas, quando questiona a visão do processo histórico como marcado por um progresso contínuo. A autora explica que o estudo da história pode se dar de vários modos, mas que no seu livro, destinado a alunos dos bachillerato, o foco central são os principais problemas ocorridos na chamada civilização ocidental, em sua etapa contemporânea, principalmente nos séculos XIX e XX.

Esto quiere decir que aborda la expansión de una cultura material y espiritual que teniendo sus primeras raíces en Europa - con el desarrollo del cristianismo, el capitalismo y las ideas y valores de la burguesía - se fue incorporando, imponiendo e afectando al resto do mundo.

En este proceso, se registraron un sinnúmero de conflictos, que llegaron a situaciones altamente trágicas y destructivas como la Primera y la Segunda guerras mundiales. También se registraron avances notables en las ciencias y las artes, en la democracia y el respeto de los direchos humanos ${ }^{197}$.

De fato, encontramos ao longo do livro muitos tópicos destinados ao estudo do capitalismo e às idéias e valores burgueses, mas não é verdade que a cultura material e espiritual sejam preocupações efetivas da autora. O desenvolvimento 
do cristianismo resume-se de fato a esparsas referências sobre a atuação da Igreja católica.

Chega a ser surpreendente o modo como as ilustrações são apresentadas nessa unidade introdutória. As legendas nem sempre identificam a imagem reproduzida e mesmo quando o fazem, é pouco provável que o leitor consiga estabelecer relação com o texto. Um bom exemplo encontramos nas duas páginas que tratam da utilidade da História ${ }^{198}$. A primeira foto mostra quatro homens, três deles semi-nús, mexendo e observando o que parece ser sementes, dispostas em uma espécie de peneira de palha. A legenda diz "Los seres humanos recuperan experiências de sus antepasados". Na outra página, a foto
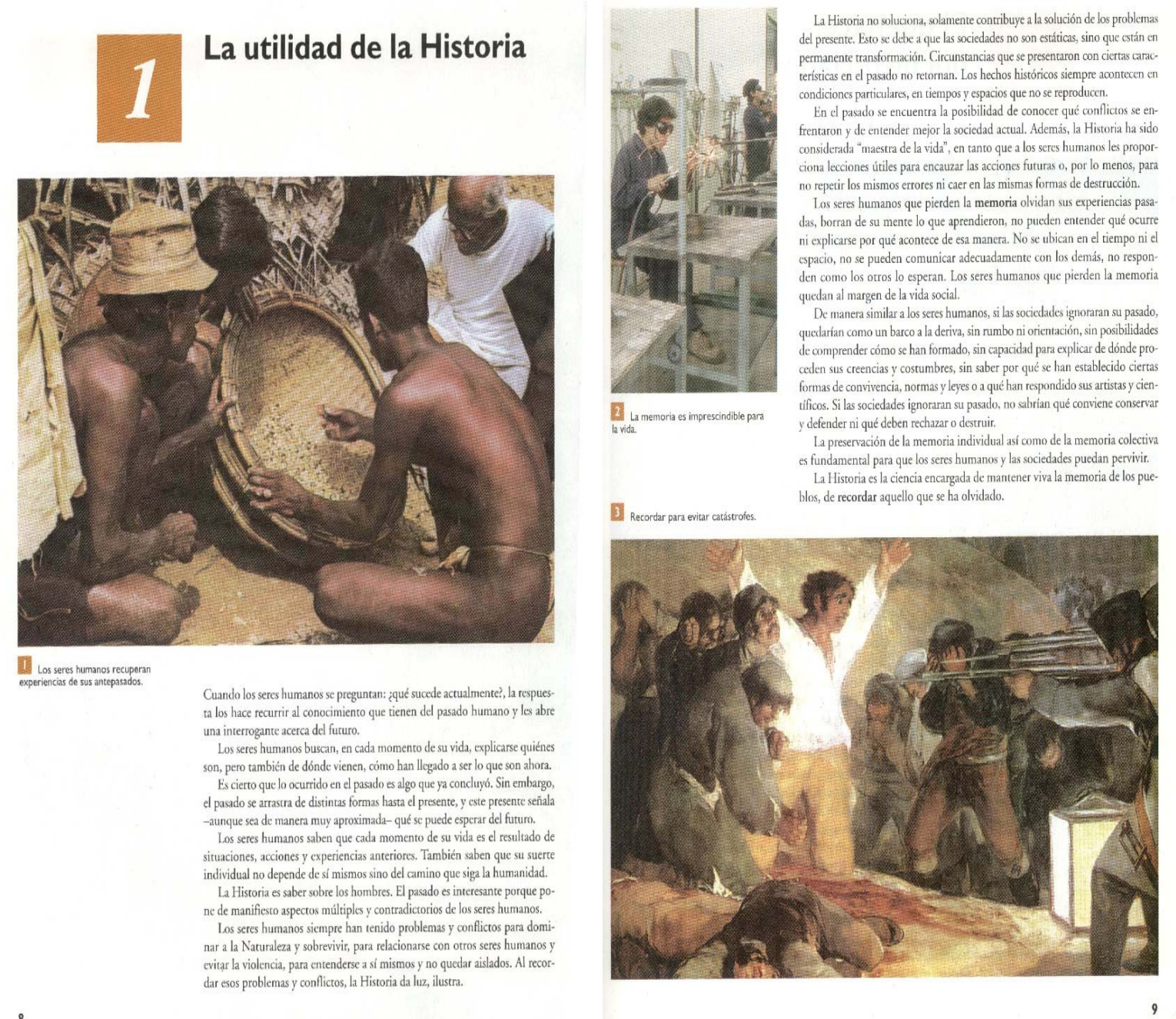

em que se vê dois trabalhadores operando máquinas tem como legenda a frase "La memória es imprescindible para la vida", enquanto a famosa tela de Francisco

198 Idem, p. 8 e 9. Lembremos que no documento Conoscimiento y Formación Básicos que debe proporcionar el bachillerato en la UNAM, o primeiro tópico programático é exatamente $\mathrm{La}$ Historia, su objeto y utilidad. 
Goya "El três de mayo de 1808 em Madrid: los fusilamientos em la montaña Del Príncipe Pio" é acompanhada da legenda "Recordar para evitar catástrofes". Essa total dissintonia entre imagens e texto, que pode ter ocorrido a revelia da autora, é encontrada em todo o livro, o que torna a iconografia quase sempre um acessório ilustrativo apenas. Nesses exemplos a gravidade é ainda maior, pois os próprios conceitos de memória e memória histórica aparecem de modo confuso, em nada ajudando o leitor.

Julieta Pérez, Geraldo Lara e Manuel Romero desenvolvem o capítulo introdutório em 30 páginas, abordando seis aspectos centrais, destacados por eles próprios:

Los conceptos de historia e historiografia como instrumentos básicos para el estudio de la historia.

El objeto de estudio de la historia.

El tiempo como una categoria fundamental en el estudio de la historia y los distintos criterios para dividir la investigación en el campo de la historia y la importancia de la objectividad de su conoscimiento.

La características y la importancia de las fuentes historicas como materia prima del historiador.

La relación de la historia con otras disciplinas y su importancia.

Las propuestas teóricas de las principales escuelas historiográficas, sus contribuiciones y algunas de las críticas a que han sido submetidas ${ }^{199}$.

O texto envereda em certos momentos para questões bastante complexas, como as correntes e subcorrentes historiográficas dos séculos XIX e XX, chegando mesmo a tratar da escola alemã, do historicismo e do estruturalismo. Não é exagero supor que o professor precisará de diversas aulas para desenvolver os tópicos abordados de modo que os alunos possam efetivamente compreendê-los.

Admitindo a validade da máxima de Cícero, segundo a qual "a História é a mestra da vida", os autores procuram demonstrar a utilidade do conhecimento histórico: pode ser apenas pelo interesse do conhecimento em si mesmo, como

199 Pérez, J. Lara, G. e Romero, M. Historia Universal - De los orígenes de la modernidad a la crisis del mundo globalizado. México: Oxford, 2003, p. 2. 
pode se dar como forma de justificar, defender ou questionar uma dada realidade. Emiliano Zapata, por exemplo, tanto foi usado para justificar os regimes priistas como serviu de símbolo de contestação do movimento rebelde em Chiapas, dizem os autores. Assim, o estudo de História, segundo eles, proporciona um conhecimento mais profundo do presente e permite a construção de identidades que dão coesão aos indivíduos de uma comunidade, externando uma idéia bastante semelhante a que vimos nas autoras brasileiras. Além disso, tal estudo reforça as atitudes de defesa e de luta frente a realidade imediata e futura ${ }^{200}$.

A introdução ao estudo de História na coleção da equipe argentina de Luciano de Privitellio é muito breve, logo iniciando as considerações sobre o período contemporâneo. Nela os autores chamam atenção para o fato de que o mundo atual é marcado por uma grande unidade, apesar das enormes diferenças que ele também apresenta. Os processos econômicos, políticos e culturais se desenvolvem em escala planetária, sendo possível associar a vida de uma primitiva comunidade tribal na Eritréia com a verificada na gigantesca Nova lorque. A associação, contudo, não deve fazer crer que vivemos uma história homogênea. Ainda assim, desde a dupla revolução, o mundo vem vivendo um processo de integração, cuja fase atual, da globalização, interliga povos de todo o planeta ${ }^{201}$. Fica implícita por essa abordagem que o aluno já conhece os fundamentos dessa disciplina, não sendo necessário retomá-los.

Já a postura dos quatro autores brasileiros é totalmente distinta da encontrada naquela obra, mas semelhante a das obras mexicanas, pois desenvolvem uma introdução em moldes bastante tradicionais, tecendo considerações sobre o conceito de história, as fontes históricas, periodização e tempo histórico. O que chama atenção e que os dois livros fazem isso desconsiderando a escolaridade anterior dos alunos. Por mais precária que tenha sido ela, é improvável que ao longo de todo o Ensino Fundamental os alunos não tenham tratado desses temas nas aulas de História. Mas o texto não leva em conta as vivências escolares dos estudantes.

201 Privitellio, Luciano de. Historia del mundo contemporáneo Desde la "doble revolución hasta nuestro dias. Buenos Aires: Santillana, 2002, pp. 13-15. 
Podemos, a guisa de conclusões preliminares, dizer que todos os autores compartilham algumas preocupações no desenvolvimento de suas obras, como a de criar condições para que o aluno compreenda melhor o mundo em que vive, de modo a ter um papel mais atuante. Subjacente a essa preocupação, estão outras, de caráter formativo, em que o estudo da história seria um meio para que os alunos comecem a formar juízos de fundo moral e ético sobre a ação dos homens e grupos sociais do passado. De algum modo, todos mencionam a relação entre o passado e o presente, ainda que não vejam essa relação sob o mesmo prisma. Na maioria dos livros explicita-se a preocupação com o conhecimento histórico mais amplo, com o qual o saber histórico escolar deve estabelecer diálogos. Nos dois livros brasileiros os autores deixam claro o seu compromisso de contribuir para que os alunos se qualifiquem para os exames finais do nível médio, denotando uma função central desse nível de ensino.

É sobre essa base que analisaremos de forma mais sistemática as concepções de história expressa por esses seis manuais. 


\title{
Capítulo IV
}

\section{CONCEPÇÃO DE HISTÓRIA E DE ENSINO: DIVERSIDADE NA UNIDADE}

\begin{abstract}
Enseigner l'histoire est un métier qui s'apprend. Comme tout métier, et particulièrement ceux qualifiés d'intellectuels, c'est un métier que I'on n'a jamais fini d'apprendre, d'apprendre par experience, $d^{\prime}$ apprendre par la reflexion theorique et pratique.
\end{abstract}

François Audigier

Estabelecidas as linhas gerais dos quadros educacionais nacionais em que se situam as seis obras didáticas selecionadas e os fundamentos que os próprios autores apresentam de suas obras, neste capítulo aprofundamos nossa investigação no sentido de identificar as concepções de história e de ensino. Retomando alguns aspectos da materialidade de cada livro, discutiremos seus aspectos visuais, incluindo aí a iconografia. A periodização e a relação passado presente são dois outros aspectos que também abordaremos.

Dentro do amplo conjunto temático abarcado pelos manuais, tomaremos a Revolução Industrial e o lluminismo como exemplares para se identificar semelhanças e diferenças entre eles, especialmente no tocante às cncepções sobre o protagonismo histórico. Em seguida, veremos como os autores procuram incorporar em seus textos algumas das contribuições historiográficas mais recentes, finalizando com uma questão central no ensino de História: das identidades. 


\section{O PROJETO GRÁFICO: A COMUNICAÇÃO VISUAL DE UM LIVRO}

No desenvolvimento de todo livro, é preciso estabelecer um projeto gráfico: tamanho e formato das páginas, área da mancha do texto (área do papel a ser ocupada pelo texto), fontes (tipos de letras) e corpo (tamanho das letras). São essas definições básicas que orientam o trabalho de diagramação, outra etapa importante na produção de qualquer livro.

Nos livros didáticos, o projeto gráfico envolve um grande número de aspectos, alcançando na atualidade grande sofisticação gráfica e visual. Do formato do livro até a gama de cores dos elementos visuais da obra, o projetista ou designer gráfico precisa determinar um conjunto grande de aspectos, sempre de acordo com as orientações e recomendações passadas pelos editores e eventualmente pelos autores, que avaliarão em que medida as sugestões são adequadas para a obra em desenvolvimento. A coerência entre o conteúdo e o visual do livro é um aspecto importante e atribuição central do editor, contando sempre com o apoio da equipe de arte, especialmente do chefe ou editor de arte $^{202}$. É preciso conciliar todos os elementos que constituem a obra com os espaços disponíveis, considerando cada página e o total delas definido para o livro, de tal modo que se encontre a melhor ocupação do papel, sem sobrecarregar visualmente as páginas.

No caso dos livros de História, além do texto central dos autores, em geral há uma série de outros elementos que constituem a proposta de uma obra: boxes, glossários, imagens, mapas, gráficos, tabelas, legendas, exercícios, seções complementares. Harmonizar todos eles em cada página - ou par de páginas, como tem se tornado comum -, requer um cuidadoso trabalho, que se torna ainda mais complexo quando o projeto gráfico define que não deve haver quebra de texto de uma página para outra ${ }^{203}$. Nesse caso, cada página conterá um ou mais

202 Em geral, os profissionais do Depto. de Editoração diretamente envolvidos com a produção de uma obra são o editor ou chefe de arte e o diagramador, sendo o trabalho desse supervisionado pelo primeiro. Fazendo uso, atualmente, de variadas e sofisticadas ferramentas eletrônicas, esses profissionais podem conferir aos livros uma configuração muito diversificada, como bem exemplificam as próprias obras analisadas.

Isso obriga, muitas vezes, a edição final só ser feita depois de uma primeira diagramação, quando será possível identificar a necessidade de cortar texto ou, ao contrário, "fechar a página" com algum elemento suplementar. Possivelmente a origem dessa prática está nas orientações feitas por psicólogos e especialistas em leitura, segundo os quais os trechos iniciais e finais de um dado texto tendem a receber maior atenção por parte do leitor, associadas à preocupações de ordem visual e da própria organização das aulas. 
tópicos integrais, havendo no alto de cada uma delas um título ou subtítulo. $\mathrm{O}$ tamanho reservado às imagens e aos mapas, bem como a forma como serão dispostos na página, são dois outros aspectos fundamentais, de tal modo que o leitor possa de fato observar o conteúdo deles, integrando-os à leitura ${ }^{204}$. Caso contrário, possivelmente esses recursos visuais desempenharão apenas papel ilustrativo. Do mesmo modo, caso haja diferentes modalidades de boxes ou atividades, é preciso criar uma comunicação visual eficiente, de tal forma que o leitor rapidamente identifique a modalidade daquele texto ou, durante a aula, localize a parte destacada pelo professor.

No Brasil, a partir de meados do anos 1990, tornaram-se comuns os livros destinados ao Ensino Médio impressos em quatro cores - ciam, amarelo, magenta e preto - a partir das quais resulta uma gama quase infinita de cores. Até então, herdeiros muitas vezes das apostilas, esses livros eram impressos apenas em uma ou duas cores (sendo uma delas quase sempre o preto). Resultou dessas mudanças gráficas um enorme aprimoramento visual nas obras desse segmento, o que coincidiu, por um lado, com um momento de maior oferta iconográfica, disponibilizada tanto por bancos de imagens estrangeiros ${ }^{205}$ como nacionais (o que explica as tremendas diferenças visuais entre um livro produzido em 1990 e 2000), e, por outro, o momento em que o segmento começou a se expandir fortemente no país, aumentando as tiragens e viabilizando os aumentos de custos que essas melhorias acarretavam. A maior concorrência entre as editoras foi outro fator explicativo para essas mudanças.

$\mathrm{Na}$ Argentina se verifica a mesma sofisticação da produção editorial brasileira, mas com uma expressiva diferença no tocante à produção gráfica: o uso mais generalizado de papel couchê. Esse tipo de papel, que recebe uma camada de gesso na sua superfície, proporciona uma impressão sempre de melhor qualidade, valorizando visualmente a obra. No México, ao contrário,

204 Nesse sentido, as legendas tanto das imagens como dos mapas são muito importantes, pois elas é que darão sentido aos mesmos. Sabemos que a apreensão que o leitor faz de uma página considera todos os elementos que nelas estão contidos e que o sentido atribuído pelo leitor é resultante da interação de todos esses elementos simultaneamente.

A estabilidade econômica do país, especialmente no câmbio, favoreceu a ampliação desse setor no Brasil, ao mesmo tempo em que tornou mais acessível a aquisição dos direitos de reprodução dessas imagens por parte do mercado editorial de livros didáticos, uma vez que as agências de publicidade são seus principais clientes. As tecnologias de comunicação, nos últimos anos, favoreceram ainda mais o emprego dessas imagens, pois elas deram acesso a bancos virtuais mundiais. Essa é a razão para que se encontre hoje nos livros didáticos um leque infinitamente maior de imagens do que há cinco ou dez anos. 
praticamente nenhuma dessas características se fazem presentes nos livros para o nível médio (bachillerato) ${ }^{206}$, ainda que sejam verificadas em outros segmentos, constituindo um outro indicativo de que as tiragens devem ser mesmo pequenas. Encontramos em nossa pesquisa um grande número de obras impressas apenas em uma cor. Como já apontamos, uma das obras que analisamos procedente daquele país, mesmo tendo sido recentemente lançada, foi impressa em duas cores (azul e mostarda) ${ }^{207}$.

As melhorias editoriais e gráficas verificadas nos últimos anos ${ }^{208}$ ampliaram a oferta de livros, revistas e outros tipos de impressos. A maior circulação deles, associada à diversificação das mídias a que têm acesso os jovens, promoveu ma grande transformação visual nas obras didáticas como um todo. As inovações começaram pelos livros denominados paradidáticos e depois se estenderam para os manuais. São muito visíveis, por exemplo, a influência das revistas, em que a diagramação é freqüentemente mais "solta". Imagens recortadas (sem fundo), infográficos, uso de fontes coloridas e com design sofisticado (nem sempre muito legíveis, porém) passaram a ser encontrados nos livros. Disso resulta que a proporção entre a área de texto e os demais componentes da obra alterou-se significativamente. No caso dos livros brasileiros, a principal conseqüência foi que eles começaram a alcançar elevado número de páginas, pois foram preservados os conteúdos.

\section{FORMA E CONTEÚDO: CONCEPÇÃO DE HISTÓRIA E PROJETO GRÁFICO}

Podemos começar a identificação da concepção de História em um livro didático pelo seu projeto gráfico. Isso é bastante evidente nas obras analisadas, cujos projetos são bem distintos. Por exemplo: em uma obra em que o discurso dos autores é praticamente exclusivo, havendo poucas inserções de textos de terceiros, por meio de citações ou boxes complementares, o projeto gráfico tende a ser simples, sem recortes ou quebras, proporcionando a sensação de limpeza visual, como é o caso do livro de Marialba Pastor. Quando, entretanto, no discurso

206 A única exceção é exatamente o livro da Editora Santillana, o que reforça a nossa hipótese de que a diferença na apresentação visual seja um dos fatores que muito contribui para sua expressiva vantagem no ranking de vendas.

207 Na página de créditos há a informação de que o livro teve uma tiragem de 3000 exemplares.

208 Kazumi Munakata informa que os processos de informatização na produção editorial começaram no final dos anos 1980, trazendo importantes impactos, especialmente na organização departamentos de edtoração. Cf. Munakata, Kazumi. A produção de livros didáticos e paradidáticos. Op. cit. 
dos autores se entrecruzam outras falas, extraídas tanto de documentos como de textos historiográficos, o projeto gráfico precisa sinalizar com clareza essa polifonia, identificando a origem desses diversos textos, de modo que o leitor seja capaz de estabelecer diálogos entre eles. O efeito pedagógico dessa variedade textual tenderá a ser maior quando ela revelar posições diferentes - ou mesmo conflitantes -, pois os alunos poderão perceber como pode haver diferentes posições ou opiniões sobre um dado tema.

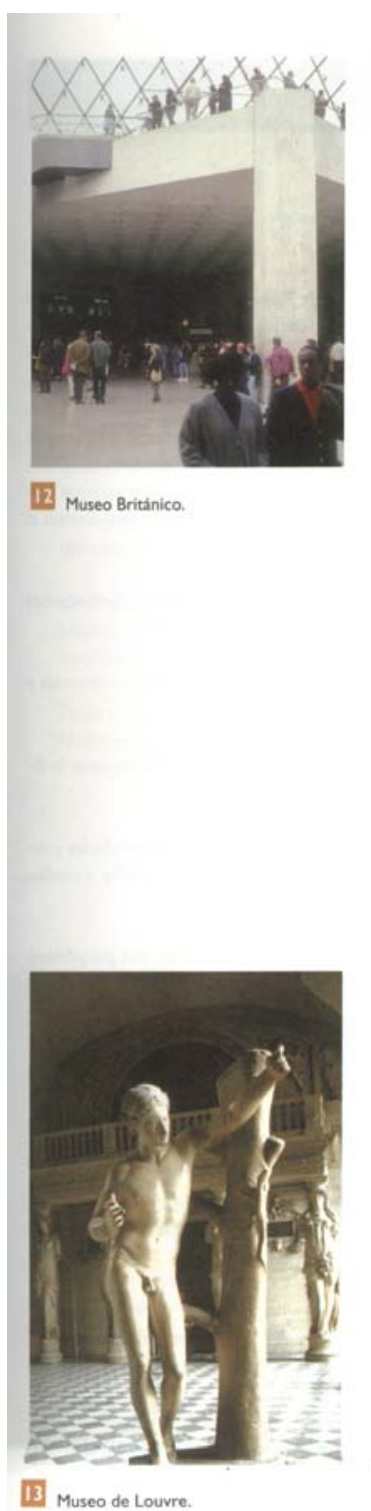

El avance tecnológico puede ser vertiginoso y benéfico para ciertos grupos sociales, mientras grandes masas siguen empleando antiguas herramientas de trabajo. Por ello, cada sociedad tiene su propia historia, y sus grandes cambios y transformaciones se ubican en momentos distintos a los de las demás. No obstante, existen elementos $y$ rasgos de las sociedades que permiten hacer algunas generalizaciones $y$, por medio del método comparativo, señalar semeanzas $y$ diferencias entre unas $y$ otras.

El desarrollo humano ha sido desigual. Algunas civilizaciones alcanzaron momentos de prosperidad económica y esplendor cultural, y cayeron en la depresión e incluso regresaron a formas tribales, olvidando sus conquistas.

En la historia se registran retrocesos y discontinuidades, pero también avances $y$ continuidades.

Conocer a profundidad la historia de los diferentes pueblos $y$ naciones en sus múltiples manifestaciones y etapas es una tarea imposible para una sola persona. Por ello algunos historiadores se especializan en unos cuantos asuntos de la actividad humana: la historia de las religiones, la historia económica, la historia social, la historia política, etcétera.

Otros historiadores estudian a fondo ciertas regiones o paises. Sin embargo, también es posible tener acceso a la historia universal, al encontrar analogías entre las sociedades y al determinar los grandes conflictos que han conmovido toda la humanidad.

Entre las posibles divisiones de la historia universal, las dos más importantes han sido la división por civilizaciones y la división por grandes cambios sociales.

La división por civilizaciones parte de la idea de que, en determinado espacio geográfico, un conjunto de pueblos o naciones unifican su diversidad cultural y sus relaciones económicas -su vida material y espiritual- en torno a una serie de ideas, valores, normas, conductas $\mathrm{e}$ instituciones que comparten por un largo período. En esta modalidad pueden estudiarse las civilizaciones egipcia, china, india, grecolatina, maya, inca, azteca, islámica, judaica, ortodoxa o bien las civilizaciones africanas, occidentales, orientales, etcétera. Esta división por civilizaciones permite analizar y comparar grandes conglomerados ociales a partir de aquello que les es común.

La división por grandes cambios sociales es la más tradicional. Aquí se distinguen dos etapas denominadas prehistoria y protohistoria $y$-desde la aparición de la escritura- una tercera que se denomina historia, dividida en antigua, media, moderna y contemporánea.

Las etapas o periodos están delimitados por aquellos hechos y procesos históricos que afectaron a grandes regiones o que tuvieron efectos sobre el mundo entero. Los cortes entre una etapa y otra corresponden a rupturas, modificaciones o transformaciones profundas.

Este libro aborda la historia universal desde una particular perspectiva. En virrud de que está dirigido a alumnos del bachillerato y sigue un programa diseńado por las instituciones mexicanas de enseńanza media-superior, çentra su atención en los principales problemas ocurridos en la llamada civilización occidental, en su etapa contemporánea, principalmente en los siglos XIX y XX. Esto quiere decir que aborda la expansión de una cultura material y espiritual que teniendo sus primeras raices en Europa - con el desarrollo del cristianismo, el capitalismo $y$ las ideas $y$ valores de la burguesía- se fue incorporando, imponiendo o afectando al resto del mundo.

En este proceso, se registraron un sinnúmero de conflictos que llegaron a situaciones altamente trígicas y destructivas como la Primera y la Segunda guerras mundiales. También se registraron avances notables en las ciencias y las artes, en la democracia y el respeto de los derechos humanos. 
Isso pode ser observado nas duas obra brasileiras analisadas, ainda que os autores tenham seguido estratégias discursivas distintas. Myriam e Patrícia entrecortam o tempo todo o seu texto com excertos, em geral pequenos, de outros autores ou de partes de documentos. As páginas 208 e 209, que reproduzimos abaixo, são um bom exemplo, pois nelas as autoras inicialmente citam um texto de dois biólogos norte-americanos (que falam da história da agricultura), depois um trecho de um artigo escrito pelo historiador Evaldo Cabral de Mello, publicado na imprensa, em que ele, por sua vez, cita Celso Furtado, e, por fim, inserem um pequeno fragmento do clássico livro de Antonil, tudo isso para explicar o processo de produção de açúcar no Brasil colonial. O texto é ainda interrompido para a inserção de um boxe-glossário, em que se explica o sentido do termo cabedal, usado por Antonil, contando ainda como uma foto de menino trabalhando em uma carvoaria (de modo a estabelecer uma ligação entre o trabalho insalubre no passado - nos engenhos - e hoje - nas carvoarias - , onde ainda se utiliza mãode-obra infantil), além de uma gravura do século XVII, mostrando um engenho real, e um mapa sobre as localização das principais atividades econômicas no
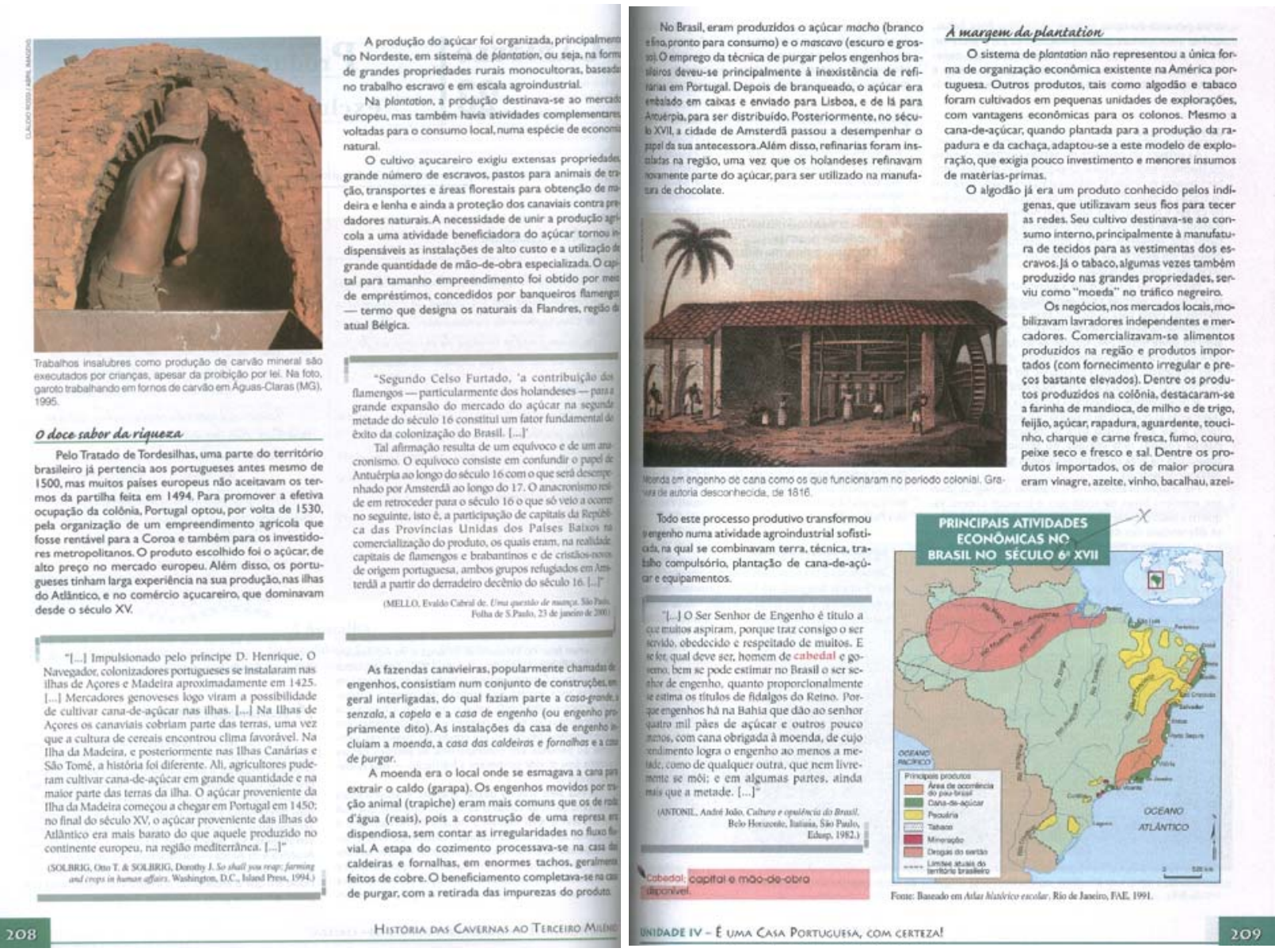
mesmo século XVII. O leitor poderá, assim, estabelecer diversas relações com essas diversas modalidades textuais ${ }^{209}$.

Os dois autores brasileiros, Vicentino e Dorigo, não entrecortam o seu discurso do mesmo modo e com tanta freqüência. As interrupções são marcadas por vinhetas grandes, como se vê na página 260, reproduzida abaixo, por meio das quais se anuncia a proposição de uma atividade de leitura, reflexão, comparação ou de outra modalidade. Embora essas entradas não ocorram em todos os capítulos, predominando portanto a exposição dos autores, ainda assim os leitores podem experimentar situações em que se confrontam idéias ou posicionamentos. Mas é importante enfatizar que apesar de os autores apresentarem diferentes visões, essa contraposição nunca é feita frente ao que os próprios autores assumem. Um bom exemplo podemos encontrar em uma das seções Discutindo a história, em que eles tecem reflexões de cunho mais teórico para introduzir a unidade de história contemporânea (século XIX). Eles apresentam de modo resumido o grande debate instaurado por ocasião do bicentenário da Revolução Francesa sobre a importância desse momento para a história da França e mesmo para a do mundo ocidental. Comentam como havia quem defendesse a idéia de que mesmo que a revolução não se irrompesse, a França teria tido o mesmo desenvolvimento político, reduzindo assim a revolução a um mito, ao mesmo tempo em que outros historiadores

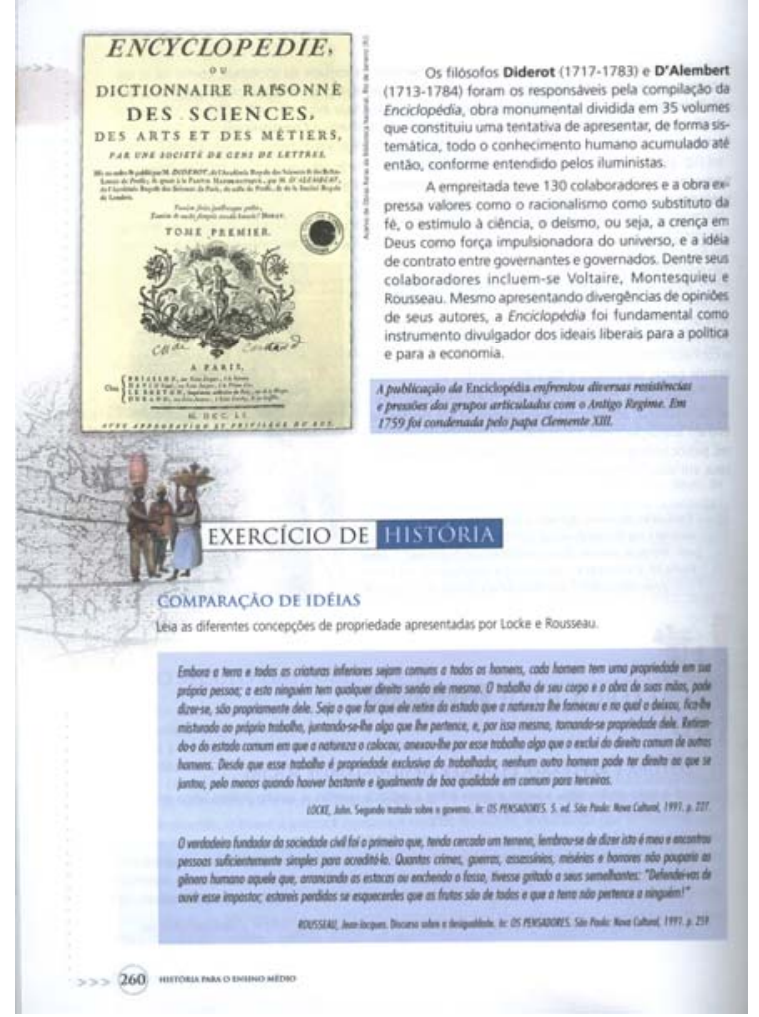

209 Por exceder as possibilidades desse trabalho, não foi possível aferir como os leitores processam todas essas informações. Reside aqui o que consideramos um aspecto muito interessante a ser investigado, visando perceber como a competência leitora dos alunos e o seu desenvolvimento "potencializam" essa variedade de textos do ponto de vista cognitivo. Nossa hipótese é a de que alunos cuja escolaridade anterior propiciou situações de aprendizagem em que estava presente essa polifonia terão agora maior possibilidade de desenvolver raciocínios mais complexos, envolvendo análises e sínteses, muito importantes nos estudos históricos. Se, no entanto, isso não tiver ocorrido, possivelmente para esses alunos o conjunto variado de informações (eventualmente conflitantes ou discrepantes) tenderá a ser visto como um dificultador da compreensão do assunto, tornando a aprendizagem mais difícil e, por extensão, menos interessante. 
alertavam que essa visão espelhava o posicionamento de setores conservadores, na esteira dos acontecimentos do fim da Guerra Fria.

Esse debate, que envolveu historiadores marxistas e integrantes do grupo dos Annales, segundo os autores "exemplificam o quanto o passado participa do presente, mediado pela memória e pela ciência histórica, e quanto é necessário continuar a estudá-lo" ${ }^{210}$. Mas no livro não encontramos contraposições entre o que defendem os autores e outras interpretações, o que seria coerente com essa introdução. O debate do qual se fala, portanto, é exterior ao livro.

No texto publicado pela editora Santillana da Argentina não há recortes no texto dos capítulos, ainda que sejam inseridos boxes complementares, alguns ocupando a metade (superior ou inferior) de duas páginas espelhadas. O que quebra efetivamente o texto são vinhetas anunciando a proposição de uma questão problema ou ainda um glossário, em que um termo é esclarecido.

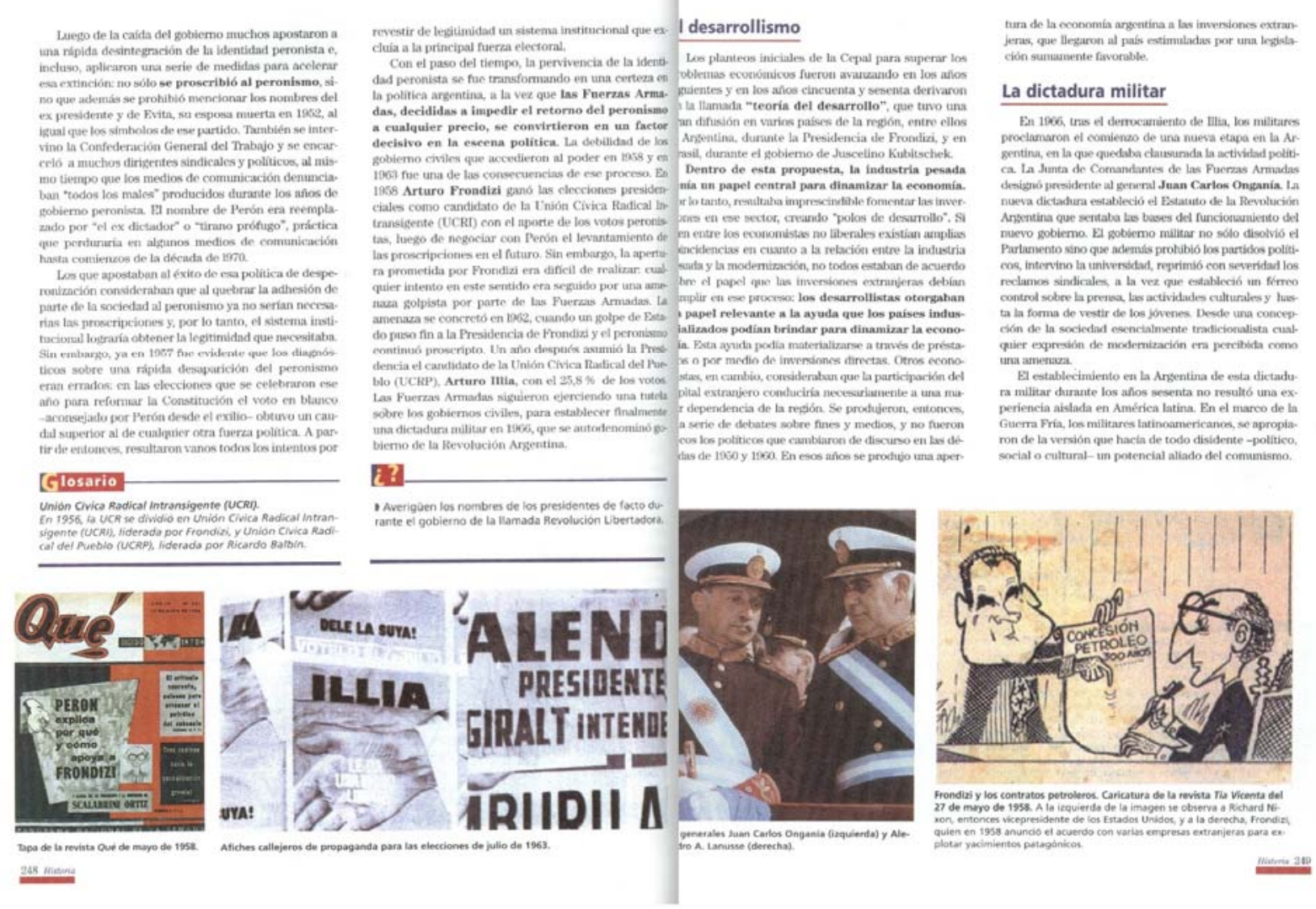

No outro livro argentino, da Puerto de Palos, os textos complementares, sejam eles dos próprios autores ou citações de terceiros, entram sempre em "falsas colunas" nas margens laterais, sem interromper a exposição central. Por 
outro lado, nesse livro o projeto gráfico desempenha um papel especialmente relevante ao indicar, no alto da página, a seção interna do capítulo em que se está ${ }^{211}$, orientando todo o tempo a leitura do aluno. Isso é reforçado pela inserção, a cada par de páginas espelhadas, de um boxe denominado Relectura, cuja numeração é seqüencial para todo o livro (totalizando115), com a função de oferecer questões de verificação de leitura, de modo que o aluno possa aferir compreensão do lido. A vinheta é, aliás, uma intervenção muito criativa e sugestiva do projetista gráfico (mostrando mais uma vez como são muitos os sujeitos que interferem na produção de uma obra): uma luminária, como que a indicar uma luz que guia o caminho do aluno no estudo dos conteúdos. Esse exemplo serve para demonstrar como uma preocupação de ordem pedagógica (organização do capítulo em quatro seções fixas) se entrelaça com uma dada concepção de histórica, (explicitada no nome dessas seções). Resulta daí uma formulação didática cujo objetivo é evitar que o aluno "se perca" durante o estudo. Queremos ressaltar com isso como forma e conteúdo estão sempre integrados, sendo esse um traço comum e marcante dos livros didáticos - ainda que nem sempre com a mesma coesão desse caso.

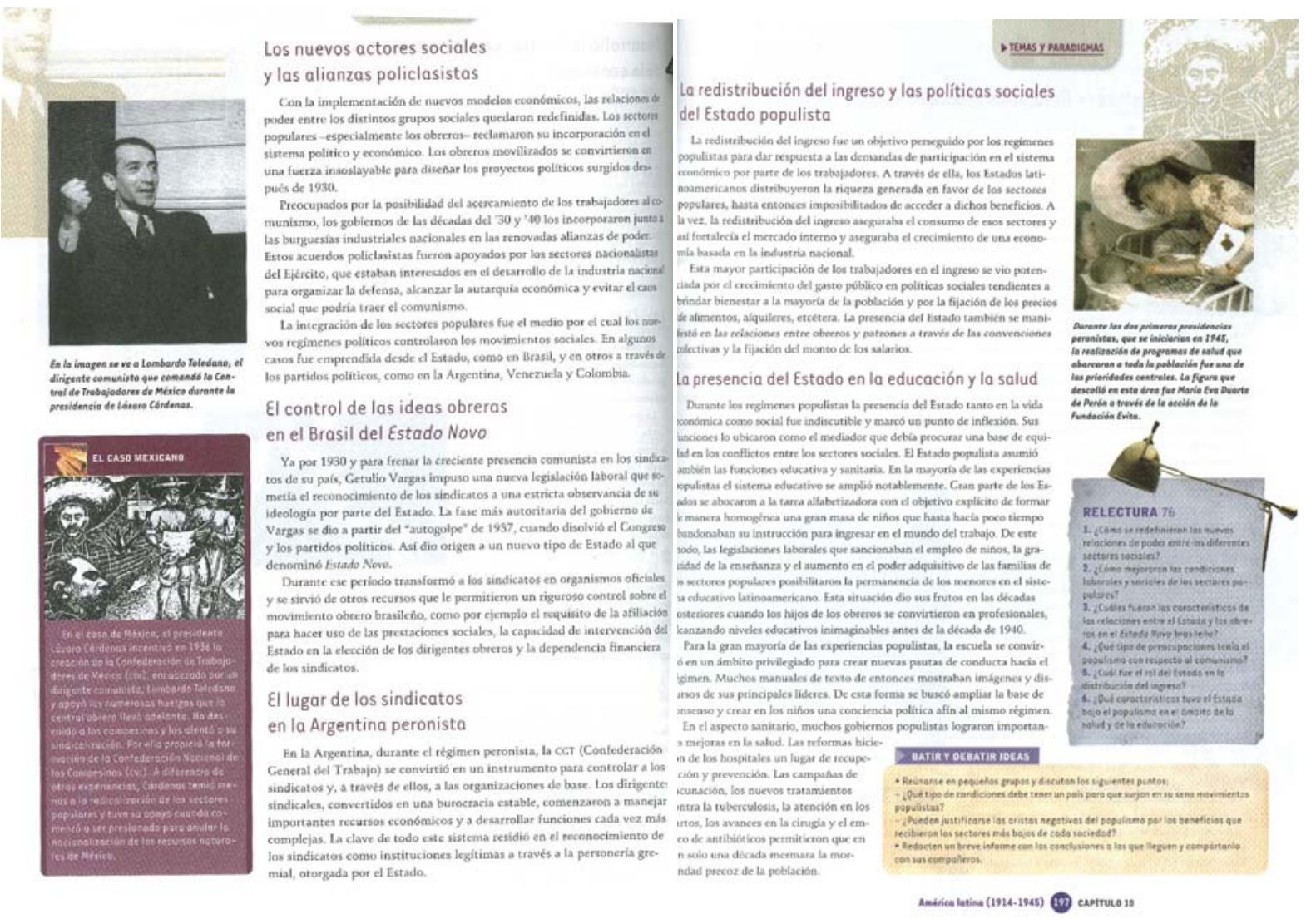

211 As seções são Los hechos, el contexto econômico y social, temas y paradigmas e la vida cotidiana. 
Analisando ainda os projetos visuais das duas obras argentinas, podemos identificar outros indicadores das concepções de história que as sustentam, agora no tocante à periodização. Em ambas os recortes temporais desempenham papel bastante importante na organização dos conteúdos. O livro publicado pela Puerto de Palos se estrutura em um duplo eixo: um, centra-se na Europa e Estados Unidos e o outro, na América Latina. Cada eixo é apresentado quase todo o tempo em capítulos alternados, respeitando recortes temporais bem precisos, como podemos ver na listagem dos capítulos a seguir:

Capítulo 1 Las revoluciones 1750 - 1870

Capítulo 2 América Latina 1810 - 1850

Capítulo 3 La Primera Revolución Industrial

Capítulo 4 La Segunda Revolución Industrial 1850 - 1914

Capítulo 5 La expansión colonial 1850 - 1914

Capítulo 6 América Latina 1850 - 1914

Capítulo 7 La Primera Guerra Mundial 1914- 1918

Capítulo 8 El período de Entreguerras 1919 - 1938

Capítulo 9 La Segunda Guerra Mundial 1939 - 1945

Capítulo 10 América Latina 1914 - 1945

Capítulo 11 La Guerra Fria 1945 - 1973

Capíitulo 12 La descolonización y el Tercer Mundo

Capítulo 13 América Latina 1945 - 1973

Capítulo 14 Nuestro dias 1971 - 2001

Capítulo 15 América Latina 1973 - 2001

Isso levou os editores a definirem um padrão para as páginas de abertura de capítulo em que o terço inferior é ocupado por uma linha do tempo que compreende o período a ser estudado, como observamos no exemplo abaixo. 


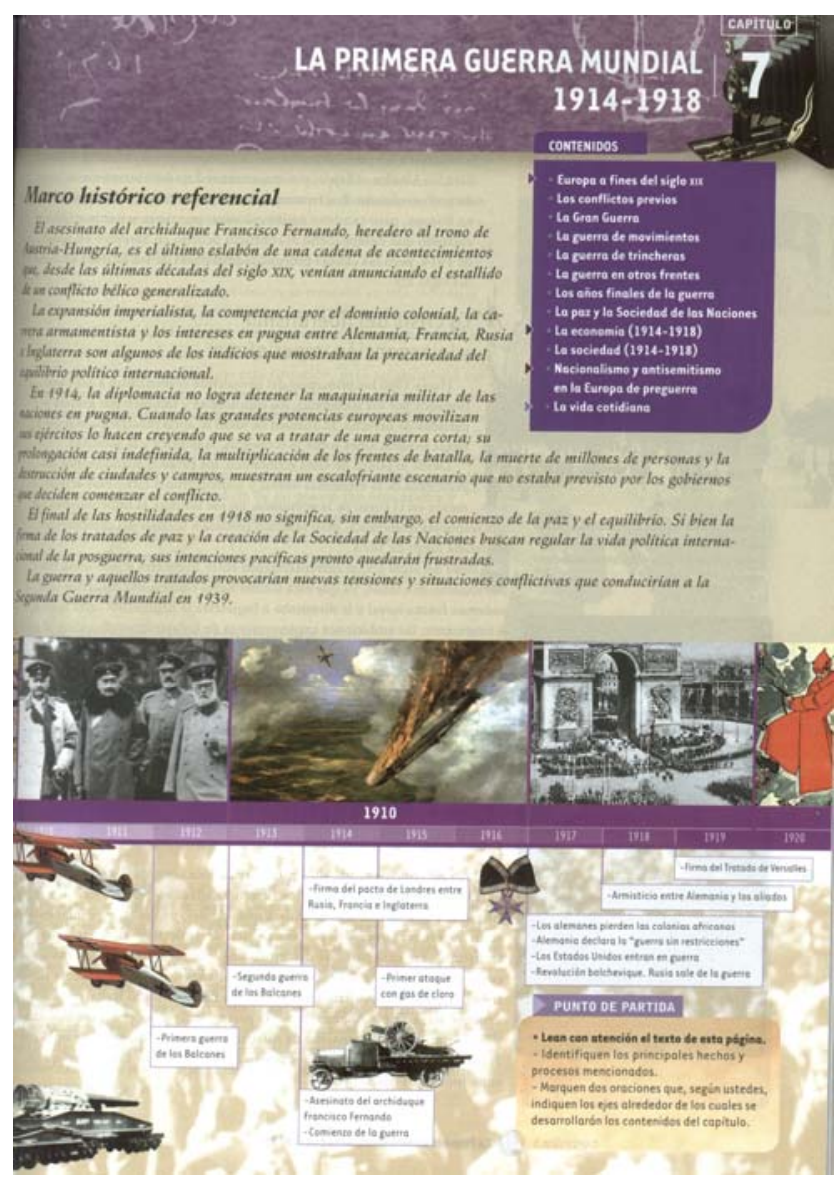

Nessa linha, certos acontecimentos são destacados em pequenas caixas de texto, acompanhados de imagens ilustrativas reproduzidas em tamanho bem pequeno. Na parte superior da mesma página, na seção denominada Marco histórico referencial, encontra-se um texto que, segundo informa a seção Organización deste libro, constitui uma síntese do que será estudado no capítulo. A página é completada com uma outra caixa de texto, que contém a lista de conteúdos e, ao pé da página, um outro pequeno boxe final, em que os alunos são instados a levantar hipóteses sobre os temas centrais do capítulo a partir desse texto inicial, grifando frases que lhe parecem mais importantes. Ao final do capítulo ele verificará se elas estavam corretas ou não ${ }^{212}$. Ainda que os autores sigam os recortes temporais propostos, nem sempre podem fazê-lo com total rigor, especialmente quando tratam da América Latina, pois os marcos foram

212 No jargão editorial esse tipo de vinculação entre seções e componentes das partes do livro é chamado de "amarração", pois todo o trabalho pedagógico é pré-estabelecido pela própria obra, ainda que o professor possa criar sua própria metodologia. Para professores inexperientes ou pouco seguros, essas amarrações são bem vistas, pois geralmente evitam que eles se percam durante o desenvolvimento dos conteúdos. 
estabelecidos tendo em vista acontecimentos mundiais e não regionais. Assim, por exemplo, ao falar das ditaduras instauradas entre os anos 1960 e 1970, é inevitável mencionar fatos para além desse marco, estendendo-se até 1973 ou 1976.

Já no livro publicado pela Santillana naquele mesmo país, os marcos temporais são definidos nos títulos das seções, sendo que os diversos capítulos que as compõem abarcam todo o período e não uma parte dele, numa sucessão temporal até se cobrir o conjunto de anos delimitados inicialmente. Fica assim muito evidente a preocupação dos autores em desenvolver com os alunos noções de simultaneidade ou tempo sincrônico, sem que se abandone o cronológico ou o tempo diacrônico, o que também se verifica no outro livro argentino. Por outro lado, a integração com a história latino-americana, e mais especificamente com a história argentina, ocorre dentro da mesma seção (unidade), e não separadamente. O projeto gráfico externa essa concepção ao apresentar nas páginas de abertura das seções (dupla e espelhada) um mosaico de imagens, geralmente atraentes e interessantes, que constam do miolo dos capítulos, como que anunciar o que será estudado (ver exemplo abaixo). A única exceção é exatamente a imagem reproduzida em tamanho maior, que não aparece em outra página e por isso mesmo é a única identificada por uma legenda. Pode-se dizer, assim, que as duas obras argentinas procuram, cada uma a seu modo, estimular o trabalho com o tempo sincrônico e romper a concepção muito usual de uma História sempre cronologicamente seqüenciada. Nesse aspecto, quando comparamos as obras argentinas com as brasileiras e mexicanas, ficam bastante evidenciadas as diferenças, mas com uma ressalva: no caso dos livros brasileiros, a inserção dos capítulos relativos à história nacional obriga a vários retornos temporais, uma vez que os temas mundiais são sempre tratados em primeiro lugar. 

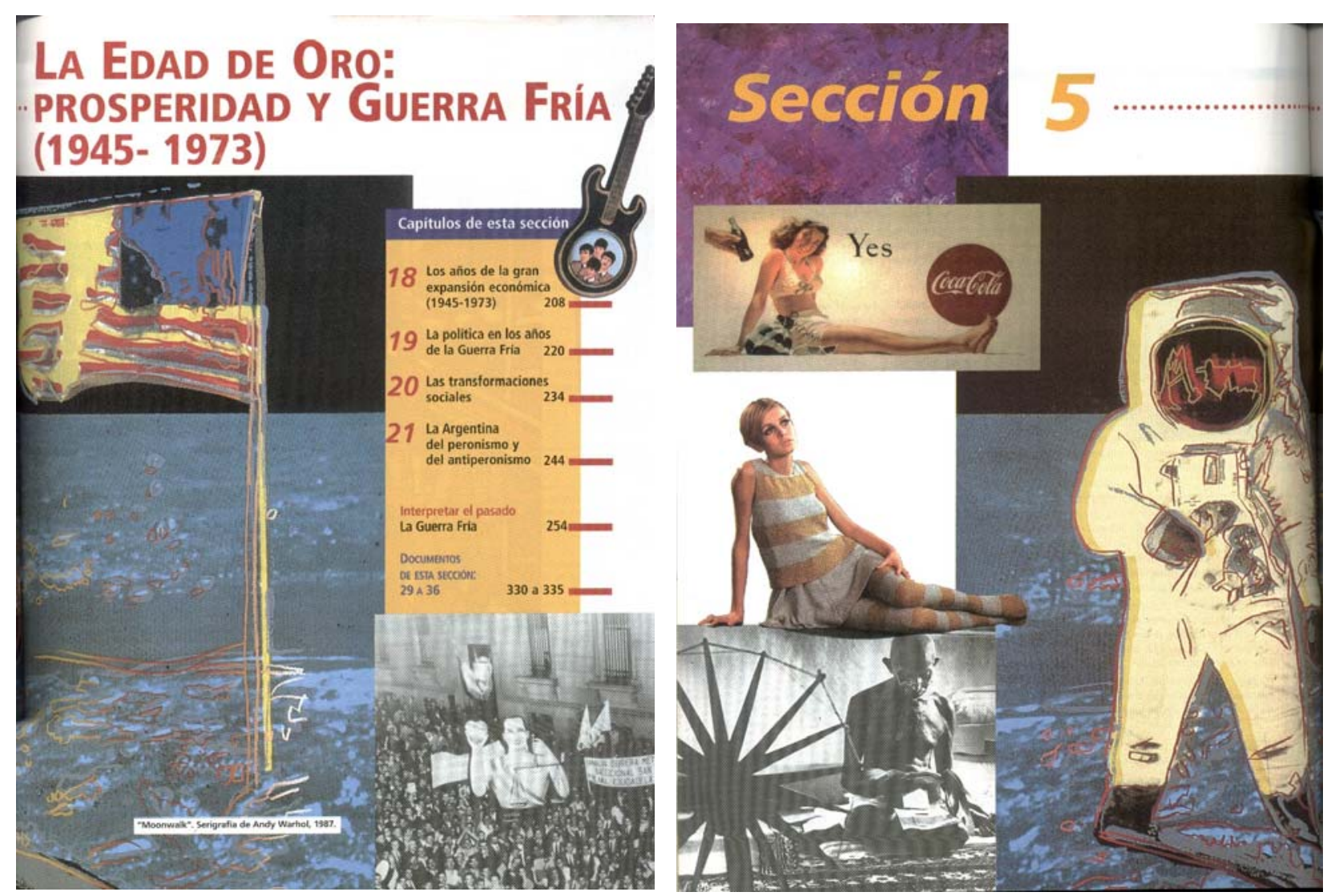

Dissemos acima que há uma estreita relação entre a proposta metodológica de um livro e sua configuração visual: uma maior inserção de textos paralelos (documentos, excertos, citações, etc.), por exemplo, acarreta um texto central mais entrecortado. Não se deve pensar, porém, que a concepção de História subjacente a uma proposta metodológica será tão mais complexa ou sofisticada quanto maior o número de elementos que a constitui. Como veremos, os dois livros visualmente mais "limpos", ambos produzidos pela Santillna (um da Argentina e outro do México) se caracterizam por perspectivas historiográficas radicalmente distintas. De onde podemos dizer que se há, sim, relação entre forma e conteúdo, ela não é simples ou direta.

\section{ICONOGRAFIA: A HISTÓRIA POR MEIO DE IMAGENS}

Analisando as seis obras, percebe-se como a iconografia nelas contidas é bastante diversa, sendo raros os casos de uma mesma imagem reproduzida em mais de um livro. Ainda assim, pode-se constatar que certos personagens aparecem com grande freqüência. Napoleão, por exemplo, aparece em cinco das seis obras ( a exceção é o livro dos mexicanos Pérez, Lara e Romero, que, por 
sinal, contém o menor número de imagens dentre todos os volumes ${ }^{213}$ ). No livro da equipe de Marisa Alonso, em compensação, Napoleão não só aparece, como isso ocorre em seis oportunidades. Marx também aparece em quase todos os livros (em dois deles, com Engels), sendo que no livro dos três autores mexicanos se preferiu colocar uma foto reproduzindo um de seus manuscritos. Esse livro também é o único que não traz imagens de Hitler. Já Lênin, Fidel Castro, Che Guevara e Mao Tsetung aparecem nos seis volumes. D. Pedro I e Vargas, além de aparecerem nos dois livros brasileiros, também são vistos no livro argentino publicado pela Puerto de Palos.

Outras constatações que nos chamaram atenção: em quatro livros, a Revolução Industrial é associada com as ferrovias; apenas no livro de Luciano Privitellio não foi reproduzida a capa da Enciclopédia de Diderot e D'Alembert e somente o livro de Miriam e Patrícia não contém uma foto da chegada do homem à Lua. Por outro lado, nos dois livros argentinos vemos fotos dos Beatles, o que não ocorre em nenhum dos demais volumes ${ }^{214}$. Darwin só aparece em duas obras, e sempre por meio de charges, enquanto que Guernica, o célebre quadro de Picasso, aparece em quatro livros.

Sistematizando, então, nossas observações no tocante à iconografia, destacamos que:

- Nos dois livros mexicanos, a iconografia esteve longe de ser um aspecto editorialmente relevante. No livro de Marialba Pastor a relação entre textos e imagens é praticamente inexplorada, fato agravado pelas legendas pouco esclarecedoras e que não associam o texto central com a ilustração apresentada. Chama atenção o elevado número de ilustrações

${ }^{213}$ Apenas para relembrar dados já apresentados:

\begin{tabular}{|c|c|}
\hline OBRA & $\begin{array}{c}\text { No.de } \\
\text { imagens }\end{array}$ \\
\hline História das Cavernas ao Terceiro Milênio & 354 \\
\hline História para o Ensino Médio & 442 \\
\hline $\begin{array}{c}\text { História del mundo contemporâneo } \\
\text { (Santillana - Argentina) }\end{array}$ & 407 \\
\hline $\begin{array}{c}\text { Historia Mundial Contemporânea (Puerto } \\
\text { de Palos - Argentina) }\end{array}$ & 624 \\
\hline História Universal (Oxford - México) & 112 \\
\hline História Universal (Santillana - México) & 361 \\
\hline
\end{tabular}

214 Nos dois livros brasileiros vemos,em contrapartida, fotos referentes ao movimento tropicalista. 
que retratam os "grandes personagens". Por outro lado, o papel empregado e a excelente qualidade de impressão tornam o livro visualmente atraente. Já o livro de Pérez, Lara e Romero foi sensivelmente prejudicado pela decisão de se produzir uma obra de custos baixo, dada a sua pequena tiragem. Além de pequeno número de imagens, a reprodução das mesmas ficou muito comprometida pela impressão em apenas duas cores.

- Os livros brasileiros trazem uma farta iconografia, mas a área ocupada por ela é condicionada pelos espaços deixados pelo texto (considerado prioritário). Há uma visível preocupação de se articular textos e imagens, o que confere às legendas função relevante. Nota-se o esforço de se apresentar uma iconografia bastante variada.

- As duas obras argentinas são as que apresentam a iconografia mais rica, valorizada pelo tipo de papel empregado na impressão. No caso do livro publicado pela Santillana, potencializa-se ainda mais esses méritos, ao reservar grandes áreas para as imagens.

\section{ABRANGÊNCIA DOS CONTEÚDOS}

Ainda que dependa pouco dos autores, a definição sobre a abrangência dos conteúdos a serem abarcados no volume é outro aspecto central quando se busca definir as concepções de História que orienta o ensino dessa disciplina. Em geral, essa abrangência é definida por propostas curriculares, formais ou não, que vigoram em um dado momento, como discutimos no capítulo II.

Fiel a uma antiga tradição de estudo da História Universal, Geral ou das Civilizações, no Brasil preserva-se o caráter enciclopédico do ensino dessa disciplina, que abarca desde os primórdios da humanidade até os dias atuais ${ }^{215}$. Logicamente que em termos práticos se trata de uma missão impossível, sendo necessário efetuar recortes e seleções. Eles são feitos mantendo-se igualmente a tradição de se privilegiar os conteúdos da história européia em detrimento até

215 Sintomaticamente, o primeiro livro no formato de volume único, que abarcava desde a Préhistória até o presente chamava Toda a história, e foi lançado em 1995. 
mesmo da história nacional ${ }^{216}$. No caso das duas obras brasileiras analisadas, muitos são os traços comuns na seleção dos conteúdos: começam com uma introdução aos estudos históricos, desenvolvem algumas questões centrais do período pré-histórico, que remetem à Revolução Neolítica e, conseqüentemente, à formação do Estado e o surgimento das civilizações da Antiguidade, com destaque para Grécia e Roma. O estudo da Idade Média é organizado de modo a se chegar rapidamente à Idade Moderna, mais precisamente ao tema estruturador do livro: o processo histórico da gênese, desenvolvimento, expansão e consolidação hegemônica do capitalismo no presente. A gênese se dá com a crise do sistema feudal, o Renascimento, a expansão marítima, as conquistas coloniais e a Reforma religiosa; ao se explicar como se deu o processo de globalização, pode-se compreender o mundo atual. Entre esses dois momentos, selecionam-se os processos considerados chaves: o absolutismo, para explicar as revoluções burguesas; a revolução industrial, para explicar os novos processos de produção e a formação da classe operária; o imperialismo, para explicar as rivalidades entre as potências, a eclosão da Primeira Guerra e a Revolução Russa; a crise do entre guerras, para explicar a crise do liberalismo, o nazi-fascismo e a II Grande Guerra; essa, por sua vez, explica a Guerra Fria, que se finda com a derrocada do bloco socialista, momento que consagra o mundo globalizado. Intercalam-se em ambas as obras capítulos de história do Brasil ${ }^{217}$.

Não é diferente a seqüência dos conteúdos dos dois livros mexicanos, com a ressalva que eles se detêm exclusivamente na história do capitalismo, o que chega a ser explicitado no livro de Pérez, Lara e Romero na apresentação, argumentando que tanto nas Escolas Nacionais Preparatórias como no Colégio de Ciências Humanas os cursos de história

${ }^{216}$ Parece bastante pertinente a hipótese de que essa ênfase cada vez maior no estudo da chamada História Geral decorre mesmo da lógica do processo de globalização, em que capacitar o aluno para que possa se inserir enquanto indivíduo nesse mundo interligado tornase uma das principais funções da escola. A esse propósito, afirma Circe Bittencourt: " Novamente a questão da identidade tem sido considerada nas propostas [curriculares] atuais [anos 1990], mas agora tendo de enfrentar a relação nacional/mundialização, no âmbito dos propósitos neoliberais que, em essência, preocupam-se mais em identificar o indivíduo como pertencente ao sistema capitalista globalizado". Bittencourt,Circe M. F. Propostas curriculares de História: continuidades e transformações. In: Barretto, Elba S. de (org.). Os currículos do ensino fundamental para as escolas brasileiras. São Paulo: Fundação Carlos Chagas, 1998, p. 144.

217 Também na seleção dos conteúdos relacionados à história do Brasil há grande similaridade. Ainda que o livro de Myriam e Patrícia dê um pouco mais de destaque ao período colonial incluindo, por exemplo, um pequeno capítulo sobre religião e religiosidade, o período monárquico e republicano são tratados com o mesmo número de capítulos nos dois livros, 3 e 5 , respectivamente. 
tienen como objeto fundamental de estúdio la historia del capitalismo, sistema que ha creado o mundo globalizado que determina a sociedade actual. ${ }^{218}$

$\mathrm{Na}$ Argentina, os conteúdos compreendem um período cronológico ainda menor, do final do século XVIII ao início do século XXI. A história das sociedades capitalistas também é privilegiada, mas há diferenças expressivas na abordagem, do que resulta um conjunto de temas distintos dos encontrados nos livros dos outros dois países. Grosso modo, encontramos em ambos os livros as mesmas informações básicas sobre o desenvolvimento dos países centrais do sistema capitalista, mas o propósito é menos demonstrar como esse processo resultou na realidade mundial atual e mais levar o aluno a perceber como as práticas sociais e culturais se transformaram ao longo do tempo. Retomaremos essa idéia em outros momentos.

Vale a pena, nesse momento, apenas registrar que:

I) ao analisamos os sumários das obras brasileiras, é flagrante a total dissintonia em relação às recomendações programáticas dos PCNs. A história temática nem de longe se faz presente, preservando-se a estrutura clássica quadripartite, com a ressalva de que no livro Das Cavernas ao Terceiro Milênio as autoras procuraram escamotear essa seqüência organizando as unidades a partir de uma outra periodização.

II) os dois livros argentinos indicam que naquele país a proposta oficial dos Conteúdos Básicos Comuns foi assumida pelas editoras, favorecendo a sua implementação nas salas de aula. Considerando que as duas obras analisadas são as líderes de vendas, podemos considerar que a proposta tem chegado à sala de aula. Resta saber se a adesão dos professores às metodologias apresentadas também é efetiva.

Portanto, do ponto de vista das reformas curriculares estabelecidas a partir dos anos 1990, os livros didáticos indicam caminhos muito diversos na sua

218 Isso ajuda a comprovar nossa afirmação de que, na falta de propostas curriculares formais para o Ensino Médio, a tradição desses dois centros vinculados à UNAM acabam por fazer com que seus programas sirvam de modelo para muitas outras escolas. 
implementação: enquanto na Argentina os livros aderiram às novas orientações, no Brasil elas praticamente foram desprezadas.

\section{A IMPORTÂNCIA DO PRESENTE}

Vimos que é bastante enfatizada pelos diversos autores a função central do estudo da história: compreender o mundo presente. Mas enquanto as brasileiras Myriam e Patrícia acreditam que o estudo da História contribui para a construção de laços de identidade ${ }^{219}$, a mexicana Marialba entende que o conhecimento do passado nos ajuda a orientar o futuro "y tomar mejores decisiones"220.

Já Vicentino e Dorigo assumem posições mais próximas dos outros autores mexicanos, Pérez, Lara e Romero: enquanto esses últimos dizem ter como uma de suas intenções principais fazer com que os alunos percebam de maneira integrada os processos históricos, mostrando as relações e contradições entre os fenômenos políticos, econômicos, sócias e culturais, os dois autores brasileiros acrescentam que o conhecimento histórico, se tomado de modo estanque, se torna sem significado, razão pela qual valorizam o estudo de como se deu, e se dá, a construção desse conhecimento, que, eles observam, não é neutro. Como os livros argentinos não trazem um texto de apresentação, não podemos aferir o que explicitamente pensam os autores a esse respeito, mas é possível assegurar que a compreensão do presente é algo central em ambos. Portanto, no tocante precisamente a essa relação entre o estudo do passado - a história -, e a compreensão do presente - o tempo do aluno - , há um consenso sobre a importância dessa questão. No entanto, os autores parecem entender isso de modo bastante diverso: Marialba Pastor externa uma concepção utilitarista, pois o estudo da História serva pra compreendermos melhor o presente e desse modo orientar o futuro, "evitando os erros do passado". Já Vicentino e Dorigo, assim como Myriam e Patrícia, consideram que é a partir de questões de problemas do presente que nos reportamos ao passado. Não se trata, porém, de buscar "lições no passado", mas reconhecer que as perguntas que nós fazemos sobre ele decorrerm das questões do presente. Daí porque nas obras desses autores todos os capítulos se iniciam com a apresentação de um problema significativo para o nosso tempo. 
Chegamos a um dos aspecto mais relevantes em nossa investigação: esses autores concebem a construção do conhecimento histórico como resultante das condições históricas - a História como filha do seu tempo. Entretanto, em diversos casos, quando as duas autoras brasileiras formulam questões que servem para orientar o desenvolvimento do capítulo, o que se constata é que elas incorrem em anacronismos - erro que elas mesmas dizem não querer cometer no seu texto de apresentação. A razão para essa falha é que se procura fazer a aproximação de dois tempos históricos de modo um tanto quanto superficial, quando não artificial. Por exemplo: o capítulo 4 trata, em quatro páginas, do longo processo desde a revolução neolítica até a formação dos estados, ponto inicial das primeiras civilizações. O capítulo é iniciado por um trecho da Carta da terra, texto escrito por Herbert de Souza, o Betinho, em que aborda a questão fundiária no Brasil. As autoras começam então o seu texto com os seguintes argumentos:

O texto de Betinho nos lembra que a desigualdade social está associada à propriedade privada da terra. Ele afirma que não precisa ser assim: é possível "abalar as cercas e mudar a história", pois a terra "é um bem de todos para todos". E, na verdade, nem sempre foi assim: quando surgiu a agricultura, maior conquista da espécie humana, os campos cultivados pertenciam a comunidades aparentadas pelo sangue $^{221}$.

Ao lado do texto vemos uma foto em que se lê a seguinte legenda:

Mulher desempregada catando comida em lixão na cidade de Timon, Maranhão, 2001. Apesar de toda a riqueza produzida no mundo, dos avanços tecnológicos e das garantias sociais estabelecidas por inúmeras legislações, a miséria causada pela desigualdade econômica é uma dura realidade para mais da metade da população do planeta ${ }^{222}$.

Em poucas linhas, portanto, aproximam duas realidades afastadas por milhares de anos, marcando a trajetória humana (implicitamente tomada como única) pela desigualdade econômica.

221 Mota, M, e Braick, P. Op. cit. p. 30. 
Segue-se a explicação de como algumas comunidades de caçadores e coletores, em diferentes momentos e por um longo espaço de tempo foram desenvolvendo conhecimentos que as habilitaram a viver do cultivo agrícolas, o que levou à sedentarização desses grupos. Disso decorreu a formação de cidades e a divisão de atribuição entre habitantes do campo e da cidade. Ao mesmo tempo ocorreram mudanças políticas, em que a antiga autoridade do patriarca foi substituída pelo rei-sacerdote, dando origem às primeiras formas de Estado.

Outra mudança fundamental ligada à formação do Estado foi o aparecimento da propriedade privada. Nas comunidades agrárias, a terra, as águas e os produtos do trabalho pertenciam à coletividade. $\mathrm{O}$ surgimento das cidades e da divisão do trabalho tornou esse quadro mais complexo, e o fortalecimento dos templos e do poder político, com seus funcionários, introduziu novos elementos de desigualdade. Uma elite ligada aos reis e aos sacerdotes passou a se apropriar de uma parte das colheitas, assim como das terras produtivas (grifo no original) $^{223}$.

Como é que as autoras retomam a questão levantada no início do capítulo? Com a proposição das seguintes questões:

1. Releia o trecho da Carta da terra, do sociólogo Herbert de Souza (Betinho), no início deste capítulo. Faça comentários sobre a afirmativa: "no Brasil, a terra também cercada, está no centro da história".

2. Procure conhecer melhor a situação das propriedades rurais em seu Estado, pesquisando em jornais, revistas, livros ou na Internet. Anote suas conclusões para discutir em sala de aula.

3. Explique por que a passagem de uma economia coletora/caçadora para uma economia agrícola, no Neolítico, foi considerada uma revolução.

4. O homem do neolítico construía diques e canais. Os açudes brasileiros podem ser comparados com essas obras? Por quê? Eles estão em terras públicas ou em propriedades particulares? Faça pesquisas em jornais, revistas, livros ou na Internet para verificar quem é mais beneficiado pela sua construção ${ }^{224}$. 
Há, evidentemente, o esforço de fazer com que os alunos relacionem o passado e o presente, mas o resultado final parece muito duvidoso, pois é provável que os alunos concluam que o problema da terra existe há milhares de anos, desde a Idade dos Metais, quando surgiu a propriedade privada. Ocorre que o sentido da propriedade privada naquele momento não é o mesmo de hoje, em sociedades capitalistas como é o nosso caso. A historicidade de ambas situações se perde.

A questão da terra é retomada mais adiante, quando se trata de Roma Antiga. Nesse caso, se faz uma associação bastante comum nos livros didáticos brasileiros, entre a lei agrária de Tibério Graco e o Movimento dos sem-terra. Aliás, é uma foto de um acampamento do MST que ilustra a página, acompanhada da seguinte legenda:

Movimento dos sem-terra, no Brasil. Os problemas advindos da propriedade da terra vêm desde o passado distante. A posse de um bem natural, como a terra, por indivíduos ou grupos restritos, só pode ocorrer se milhares de outros não puderem usar livremente este bem. A resultante disso é a miséria econômica, que no caso da propriedade da terra, só pode ser resolvida pela reforma agrária ${ }^{225}$.

Sem entrar no mérito ideológico da questão, o que se quer chamar a atenção é para o fato de que a relação entre passado e presente se faz por meio de generalizações históricas conceituais um tanto perigosas. Nem no tocante ao passado nem ao presente é correto dizer que onde quer que tenha havido ou haja a propriedade privada da terra há miséria econômica. Além disso, o que a reforma agrária pode acabar é com a concentração fundiária e, não necessariamente, com a miséria ${ }^{226}$. Portanto, buscar relações entre o passado e o presente não é simplesmente justapor situações aparentemente semelhantes. A relação deve-se dar por meio de problematizações. Nesse sentido, Vicentino e Dorigo encontraram

\footnotetext{
225 Idem, p. 73.

226 Maria Luíza Corassin esclarece, a esse respeito, que as reformas de Tibério Graco, longe de representar qualquer atitude revolucionária, visavam primordialmente "preservar a estrutura da cidade-Estado naquilo que em Roma era fundamental: a camada de pequenos e médios proprietários, na qual se recrutava o exército cívico. Corassin, Maria Luiza. Sociedade e política na Roma Antiga. São Paulo: Atual, 2001, p. 53.
} 
uma solução mais satisfatória. Assim, por exemplo, introduzem o tema da Crise de 1929 e o surgimento do nazi-fascismo com um boxe sobre especulação financeira e crise, no qual levantam as seguintes questões:

A atuação de interesses privados nas bolsas de valores gera efeitos sociais? Que grupos recebem vantagens ou desvantagens 0 considerarmos essa atuação? Os governos servem a certos interesses privados ou ao conjunto social da nação? ${ }^{227}$

Ou ainda, na abertura do capítulo que abarca desde a Guerra Fria até os anos 1990, em que discutem os conceitos de centro e periferia:

Alguns Estados tornaram-se o centro do poder político e militar mundial no período pós-Segunda Guerra Mundial; em torno deles, outros países assumiram o papel de figurantes ou até mesmo de vítimas.

Quais seriam os motivos para tal mapa de distribuição de forças e submissão, de um cenário de centro e periferia? Dentro desses países, quais grupos sociais e por que razões mostravam apoio por este ou aquele bloco de poder?

Uma última questão: Os atuais eixos do desenvolvimento capitalista possuem ou não raízes no quadro erguido no pós-Segunda Guerra Mundial, no período da Guerra Fria? ${ }^{228}$

Entretanto, em nossa opinião, o que parece mais contraditório no tocante à preocupação dos autores em fazer com que os alunos estabeleçam relação entre o passado e o presente se dá no próprio âmbito da vivência dos alunos. Como dissemos anteriormente, o aluno que ingressa no Ensino Médio carrega muitos anos de escolaridade, sendo que durante uma boa parte dela teve aulas de história. Ele, portanto, possui uma série de conhecimentos prévios, sem contar o que ele pôde aprender por meio de outros meios, como a televisão, o cinema, a imprensa, uma vez que sabemos que não é apenas na escola que o conhecimento histórico é veiculado. No entanto, nenhum dos seis livros analisados considera relevante o passado do próprio aluno como ponto de partida para o estudo da história. Quando muito, se toma como suposto o domínio de 
alguns conceitos, de algumas informações ou de alguma habilidade, como por exemplo os passos para a realização de uma pesquisa. Os casos mais gritantes ocorrem nos livros mexicanos e brasileiros, quando desenvolvem os capítulos introdutórios, quando se apresentam conceitos fundamentais da disciplina e o fazem como se fosse a primeira vez que os alunos tivessem tomando contato com tais conteúdos e definições.

La Historia estudia las acciones de los seres humanos realizadas en el pasado. Sus finalidades básicas son ayudar a los hombres a compreender mejor la sociedad en la que viven, contribuir a resolver los problemas sociales del presente y proporcionar lecciones útiles a las acciones futuras. La intención de los historiadores es saber, compreender y explicar al resto de la sociedad qué aconteció en el pasadoo, cómo y por qué sucedió de esa particular manera ${ }^{229}$.

História é um vocábulo de origem grega que significa "conhecimento por meio de uma indagação". Ele deriva de hístor: "sábio" ou "conhecedor". São muitas as definições que fizeram dessa ciência. Para o filósofo e escritor alemão Johann Gottfried von Heder (1744-1803), a história é o estudo do passado; o historiador francês Marc Bloch (1886 - 1944) definiu a história como a ciência dos homens no transcurso do tempo; o francês Lucien Febvre (1878 - 1956), também historiador, destacou que a história é o processo de mudança contínua da sociedade humana ${ }^{230}$.

É muito provável que comece aí o desinteresse e o desestímulo ao estudo, pois tudo o que o aluno já estudou é desprezado, e ele é tomado, pelo menos no texto dos livros, como uma tábula rasa. Ainda que se reconheça os inúmeros problemas de educação nos três países, não parece sensato supor que depois de oito ou mais anos de escolarização os alunos precisem ser apresentados a uma definição de história desse tipo. Poderia-se trabalhar a historicidade do conceito, mostrando como hoje a história pode ser compreendida. Mas nenhuma obra o faz, 
denotando que o presente de que se fala não é exatamente o tempo do aluno. De onde se conclui que a história, na verdade, é sempre exterior a ele ${ }^{231}$.

\section{REVOLUÇÃO INDUSTRIAL E ILUMINISMO: DOIS TEMAS CLÁSSICOS NO ENSINO DE HISTÓRIA}

Entre os muitos conteúdos contemplados nos livros didáticos, alguns podem ser considerados clássicos, como por exemplo o Renascimento, a Reforma Religiosa, o Absolutismo e as duas guerras mundiais. Um outro é o Iluminismo, geralmente tomado como "divisor de águas" entre a Idade Moderna e Contemporânea. Dentre esses temas recorrentes, selecionamos o lluminismo e a Revolução Industrial para fazer uma análise mais detida por dois motivos: primeiro, ambos são desenvolvidos nos seis livros e, segundo, porque eles proporcionam a oportunidade de realçar um conjunto de aspectos relevantes e representativos para o nosso propósito de identificar as concepções de história e de ensino presentes nas obras.

Comecemos nossa análise pelas duas obras brasileiras:

I) Vicente e Dorigo fecham a unidade sobre a Idade Moderna com dois capítulos: um destinado ao estudo do lluminismo e outro à Independência dos Estados Unidos. A unidade seguinte, que cobre todo o século XIX, é iniciado com o estudo da Revolução Francesa, marco inaugural da era contemporânea, ao qual se seguem outros nove capítulos organizados a partir de critérios espaciais (Europa/Estados Unidos, América Espanhola, Brasil, Ásia e África ${ }^{232}$ ) e cronológicos.

II) Myriam e Patrícia, a rigor, seguem a mesma concepção, com a diferença que deliberadamente evitam qualquer associação da divisão das unidades do livro com a periodização tradicional. Desse modo, a unidade denominada "A Era das Revoluções" (uma alusão evidente a Hobsbawn, a quem citam já na epígrafe do primeiro capítulo), começa por tratar da "Universalidade, individualidade e autonomia", ou seja, a difusão do

${ }^{231}$ É curiosa a constatação quando sabemos que nas primeiras séries do Ensino Fundamental muitas escolas, professores e livros didáticos desenvolvem os conteúdos históricos tendo como referência a vida do aluno e de sua família. De uma história "egocentrada" os alunos são remetidos para uma outra em que ele e seu grupo social mais próximo não parecem ter nenhuma relação, exceto "pertencerem a um só mundo globalizado".

${ }^{232} \mathrm{Na}$ verdade Ásia e África são abordados em função da partilha imperialista e não porque se considera relevante a história dos povos desses continentes em si mesmos. Voltaremos a essa questão mais adiante. 
ideário iluminista, que segundo as autoras "teve origem no século XVII e se desenvolveu especialmente no século XVIII"233. O dito capítulo é concluído com um sugestivo trecho de artigo de Robert Darnton ${ }^{234}$, em que se argumenta, a propósito do advento do euro, que os iluministas, por seu cosmopolitismo lingüístico e cultural, podem ser considerados defensores da idéia de uma Europa unificada, ao contrário das ideologias nacionalistas, que jogaram os povos dos continentes em uma série de confrontos sangrentos. Parece bem clara a ligação entre as idéias que as autoras visam realçar: o iluminismo "preparou", primeiro, o terreno para o triunfo da burguesia e, vencidas as rivalidades entre os Estados-nação, no pós-II Guerra, "preparou” a União Européia e o euro. A razão iluminista, apesar das ameaças da barbárie de que fala Hobsbawn no texto introdutório, continua sendo um alicerce do mundo contemporâneo. O tempo histórico entre os século XVIII e a atualidade são portadores de uma unidade e representam uma continuidade.

III) O grupo de Marisa Alonso também toma as idéias iluministas como precursoras das revoluções Industrial e Francesa, da Independência dos Estados Unidos e do ciclo revolucionário de 1820, 1830 e $1848^{235}$. Portanto, é o mundo das idéias anunciando o novo mundo das práticas políticas (regimes monárquicos constitucionais, em que vigoram ideais liberais), práticas econômicas (laisser-faire) e sociais (fim dos privilégios por nascimento e valorização dos méritos individuais). Chama atenção,

233 Mota, Myriam e Braick, Patrícia. op. cit., p. 250. Para as autoras, as revoluções inglesas do século XVII já são eventos dentro dos marcos iluministas, tanto assim que denominam o capítulo que trata desse tema de "A ilha da vanguarda iluminista" (p.257).

Trata-se do artigo " Iluminismo preparou a Europa do século XXI", publicado pela Folha de São Paulo em 21 de julho de 2002.

235 Essa associação parece alcançar o grau mais elevado no livro de Pérez. Lara e Romero, quando os autores definem revoluções burguesas os acontecimentos que contribuíram para o desenvolvimento da burguesia. O capitalismo já tinha se implantado plenamente no século $\mathrm{XVII}$, quando os estados nacionais estavam consolidados graças à aliança dos reis com a burguesia. O absolutismo foi uma saída encontrada para a crise dos anos 1600 ( Guerra dos Trintas Anos, recessão econômica, rebeliões populares e conflitos religiosos), tendo representado o fortalecimento do Estado em âmbitos onde pouco atuava, como o econômico, ao mesmo tempo que solapava o poder da nobreza feudal e do clero. "Uno de los aspectos que demuestran el desarrollo paralelo de las monarquias absolutistas y las primeras etapas del capitalismo es el mercantilismo, política económica que caracterizó a los países europeus desde el siglo XVI hasta entrado el XVIII", afirmam os autores. Faz sentido, portanto, incluir no capítulo denominado Las revoluciones burguesas y la expansión del mercado mundial a guerra de independência da Holanda, a Revolução Inglesa, a Revolução Industrial, o Iluminismo, o despotismo esclarecido, a Independência dos Estados Unidos, Revolução Francesa e o período napoleônico. Ver Pérez, Lara e Romero, capítulo 3, p.63 a105. 
entretanto, a ligeireza com que o tema do lluminismo é tratado: quatro breves parágrafos.

Luciano de Privitellio e equipe adotam uma abordagem diferente e original. Para explicar as transformações processadas entre a segunda metade do século XVIII e a primeira do século XIX, inicialmente fala-se do sério problema decorrente da invenção da lançadeira volante: o novo equipamento exigia maior suprimento de fios, o que era inviabilizado pelas limitações técnicas de então. A superação dos entraves só veio a ocorrer nos anos de 1760 e 1780, quando inovações tecnológicas, relativamente simples, possibilitaram um expressivo aumento de produtividade no fabrico de fios. A produção artesanal deu lugar, então, à produção manufatureira, com vários impactos sociais. Pouco mais tarde, entre 1789 e 1850, eclodiu uma série de movimentos - as revoluções burguesas - que puseram fim à sociedade estamentária, hierárquica e aristocrática e instaurou um novo modelo de sociedade em que vigoravam outros valores. Na Inglaterra, antes disso, já se instalara um certo modelo político liberal, centrado na idéia de liberdades individuais. Na França, porém, a experiência do despotismo esclarecido havia fracassado, uma vez que tanto a nobreza (temerosa de perder privilégios, frente a um monarca e a uma burguesia mais fortes), a burguesia (satisfeita com os enlaces que havia construído com a administração então existente) e os setores populares (por suspeitarem que seriam eles que pagariam pela modernização econômica) não se dispuseram a apoiar o rei em seus intentos reformistas. O debate, então, centrou-se em torno das questões da soberania, do sufrágio e da representação. Nele, estava posto uma outra concepção de liberalismo político, menos centrado no indivíduo e mais embasado no princípio de que somente a igualdade perante a lei asseguraria a plena liberdade. As leis, por sua vez, só poderiam ser expressas por meio da vontade popular, sinônimo mesmo de razão, segundo os ensinamentos de alguns iluministas. Mas essa expressão popular não era a mera somatória das expressões individuais e, sim, a vontade do povo. Esse, por sua vez, constituía a nação e, por extensão, a vontade popular era a vontade nacional. Disso decorreu uma série de embates que marcaram profundamente a história francesa ao longo de boa parte do século XIX, em que liberais moderados e radicais (democratas) se enfrentaram por diversas vezes, inclusive pegando em armas. Em meio a esses debates ocorreu uma importante mudança: deslocou-se o foco ideológico do racionalismo iluminista 
para o do enaltecimento da tradição, dos verdadeiros sentimentos populares, em que se associava a pobreza com a virtude. Por esse motivo, os autores do manual não discutem o iluminismo "antes" de todo o processo da "dupla revolução", preferindo coloca-lo apenas no capítulo 6 , como contraponto às idéias do romantismo, que embasava essa nova visão de mundo.

Uma exposição dessa ordem revela uma concepção de história mais problematizadora: as mudanças tecnológicas não ocorrem do dia para a noite e elas também geram novos problemas; não existe um modelo único de revolução política; o mundo das idéias não antecede os enfrentamentos políticos e sociais; as mudanças empreendidas nos processos produtivos não colocavam frente a frente apenas burgueses e operários, mas os tradicionais grêmios artesanais, a burguesia comercial, os mestres-empresários, os operários-camponeses e os novos trabalhadores fabris. A sociedade torna-se mais complexa, os grupos sociais mais matizados, fugindo-se dos esquematismos simplistas.

A diferença dessa concepção frente às demais fica mais evidente quando analisamos a explicação dada para o pioneirismo inglês no processo de industrialização. Escrevem os autores:

\section{Los primeros industriales fueron sobre todo los maestros artesanos.}

Éstos incorporaban la nueva tecnología y se despreocupaban por la calidad del producto, contrataban a sus antiguos compañeros como trabajadores asalariados y, de ser necesario, a los numerosos desocupados que llegaban a la ciudadad desde el campo. Muchos empresarios dedicados a la producción domiciliar decidieron continuar con su negocio pero aplicando los nuevos metodos. También hubo industriales que, en su origen, eran campesinos desplazados por el processo de cercamiento de sus tierras. Algunos llegaban a las ciudades con el pequeno capital obtenido de la venta de sus tierras a la gentry y no dudaban en invertir en una fábrica. Así ocurrió con Robert Peel, uno de los más destacados industriales ingleses, quien se vio obligado a vender sus tierras y comensó a producir textiles. Con el tiempo, ganó una inmensa fortuna y fue ennoblecido. Luego de su muerte en 1830, su hijo se transformó en primer ministro de Gran Bretaña: fue el primer 
industrial en ocupar ese lugar, consagrado con su llegada a la cima política el poderío económico y social que esta nueva classe habia sabido ganar-se.

Como podemos advertir, el impulso original de la industrialización britanica no estuvo a cargo de los grandes milionarios burgueses dedicados al comercio de importación y exportación. A ellos les iba muy bien en sus negocios, y quizá por eso ninguno advirtió que detrás de las horribles fachadas de las fabricas estaba el futuro de las más grandes fortunas. Por eso miraron con desdén y hasta desprecio a los primeros industriales, a quienes consideraban indignos de su status. Sin embargo, muy pronto tuvieron que revisar sus opiniones a causa dos milliones acumulados por los industriales [...] (grifo no original) ${ }^{236}$.

Como podemos observar, os burgueses ganham claramente concretude nessa exposição, que mostra também como havia conflitos entre eles. O futuro não estava selado, tanto assim que uma parcela dos burgueses ligados aos empreendimentos comerciais não se deu conta de que a atividade industrial suplantaria a mercantil. Nem todo camponês expulso do campo tornou-se proletário, ainda que esse tenha sido o destino da grande maioria. As explicações generalizantes e de difícil compreensão encontradas nos demais livros ganham nesse caso contornos mais claros e historicamente consistentes nessa exposição. Vejamos como Marialba Pastor trata o mesmo assunto:

¿Por qué ocurrió este fenómeno en Inglaterra?

Aquí se habia conjuntado una serie de factores favorables:

- Desde el siglo XVII había acumulado capitales procedentes de la exploración colonial y las transacciones comerciales ultramarinas.

- Los pequeños, medianos y grandes comerciantes se habían multiplicado para atender la demanda de los mercados internos y los negocios internacionales.

- Las pequeñas industrial rurales habían crecido.

- Se habia desarrollado un sistema bancario que facilitaba préstamos para la inversión y participaba del desarrollo de la economia ${ }^{237}$. 
- La Revolución Inglesa habia instaurado un sistema de gobierno que defendia los intereses de la burguesia y el liberalismo económico.

- La ética puritana promivía el trabajo, el harroro y la austeridad ${ }^{238}$.

Nesse modelo explicativo tudo se encaixa à perfeição, sem conflitos, sem contradição. A questão está muito menos nos argumentos elencados, que de resto também estão presentes no outro livro, mas na forma de articulá-los. A tentativa de simplificar os fatores que explicam o pioneirismo inglês redundam numa concepção de história simplista. A outra abordagem, apesar de mais discursiva e aparentemente menos simples, deve resultar mais compreensível para o aluno, ainda que a forma de exposição (a listagem em tópicos) deva favorecer o estudo do aluno se o que se quiser dele for apenas a memorização ${ }^{239}$.

O que queremos sublinhar aqui é a presença marcante nos livros didáticos de uma concepção teleológica da história. Para os leitores, provavelmente, a ascensão da burguesia em geral, e da inglesa em particular, já estava plenamente configurada pelo menos desde o século XVII. O processo histórico apenas confirmou um destino pré-estabelecido. A história não é um campo de possibilidades, mas a concretização de uma predestinação.

Chegamos, então, a um dos temas centrais quando se discute concepção de história: os seus sujeitos.

\section{SUJEITOS E PROTAGONISTAS}

Ao analisarmos os seis manuais, procuramos verificar que concepção de sujeitos históricos os autores externavam em seus livros, por considerar esse aspecto fundamental para a definição da concepção de história neles presentes. Percebemos que rigorosamente não há uma única concepção, mas a idéia de

${ }^{238}$ Pastor, Marialba. Op. cit. p. 34.

239 Um outro exemplo interessante que pode ser mencionado é que os autores não limitam às ferrovias e ao barco a vapor as inovações tecnológicas que jogaram papel importante na aceleração dos fluxos de mercadorias e pessoas, incluindo igualmente o telégrafo, uma vez que promoveu uma verdadeira revolução na circulação das informações, dando especialmente à imprensa um novo papel. 
protagonismo histórico vai se alterando ao longo dos capítulos, em decorrência mesmo dos temas e das abordagens selecionadas.

Quando analisam a Revolução Francesa, por exemplo, assunto que merece espaço relativamente grande na maior parte das obras ${ }^{240}$, os autores cuidam para caracterizar os diversos grupos sociais envolvidos no movimento. Assim, há quem mostre o clero dividido em pelo menos dois grandes grupos, e a burguesia como grupo constituído de modo heterogêneo, do mesmo modo que os camponeses e os trabalhadores urbanos. A nobreza é o grupo geralmente apresentado como o mais coeso nessas explicações.

Com o aprofundamento da revolução, divergências entre os jacobinos deram origem ao grupo dos girondinos. O nome faz referência à província francesa da Gironda, de onde provinham muitos integrantes desta tendência que passou a defender os interesses da burguesia e das correntes liberais. Mais popular que a associação dos jacobinos, o Clube dos Cordeliers tinha em sua composição representantes da população mais pobre dos subúrbios de Paris, inclusive mulheres. A mensalidade dos Cordeliers era bem acessível, equivalente ao preço de um pão de 460 gramas no período revolucionário. Assim, o clube acabou se tornando o ponto de encontro dos sans-culottes (grupo formado por pequenos comerciantes, artesãos e assalariados) que ali discutiam questões como a necessidade de vigilância sobre os eleitos e os funcionários públicos administrativos ${ }^{241}$.

Nas reuniões [da Convenção Nacional], sentados à direita da presidência das sessões, ficavam os deputados girondinos, que desejavam consolidar as conquistas burguesas, estancar a Revolução e evitar a radicalização. Ao centro ficavam deputados da Planície ou Pântano - assim denominados por se agruparem na parte mais baixa -, burgueses sem posição política mais definida. À esquerda, formando o partido da Montanha, pois colocavam-se na parte mais alta do edifício, ficavam os representantes da

240 A exceção é o livro de Alonso e equipe, que reserva apenas 3 páginas para tratar desde os acontecimentos que antecederam a eclosão da revolução até a ascensão de Napoleão. Curiosamente, como já apontamos, esse é o personagem histórico que possui maior número de imagens no livro: no capítulo são cinco, somadas a mais duas na seção denominadas Los Protagonistas.

241 Mota, M. e Braick, Patrícia. Op. cit. p. 278. 
pequena burguesia jacobina, que liderava os sans-culottes, defensores do aprofundamento da Revolução (grifos no original) ${ }^{242}$.

No desenrolar dos acontecimentos, ficam evidenciados os conflitos entre os vários grupos e mesmo dentro deles próprios.

Cansados de los abusos de sus señores y del despojo de sus bienes, los campesinos tambien mostraron su malestar cuando los rumores de lo que sucedía en Paris llegaron a sus oídos. Estallaron rebeliones campesinas que tomaron castillos y quemaron los cuardenos de quejas de los señores feudales, donde estaban registradas sus deudas (grifo no original) ${ }^{243}$.

Toda la sociedad fue movilizada para la guerra: hubo reclutamientos masivos y obligatorios, racionamiento de alimentos y precios máximos para controlar la economia. Los sans-culottes, antes aliados de los jacobinos, comenzaron a movibilizar-se contra el gobierno, pero fueron reprimidos ${ }^{244}$.

No entanto, a medida que os tópicos do conteúdo vão se sucedendo, as diferenças internas entre os vários setores sociais se diluem, de modo que o protagonismo passa a ser desempenhado por classes sociais caracterizadas como homogêneas e coesas, sobretudo pela nobreza conservadora em seus estertores, pela burguesia e pela nova classe social, o operariado.

El gobierno napoleônico presentaba contradicciones profundas: las liberdades individuales existían por derecho, pero no en la realidad. La centralización del poder daba la apariencia de retrocesso, pero las reformas ayudaron a consolidar algunos principios basicos de la Revolución francesa y la burguesia que la encabezó. La antigua nobleza encontró un ambiente propicio para regresar y se adhirió al regímen napoleonico, pero no recobró más preciados privilegios ${ }^{245}$.

\footnotetext{
242 Vicentino, C. E Dorigo, G. Op. cit. p. 296.

243 Pastor, Marialba. Op. Cit p. 59.

244 Alonso et al. Op. Cit. p. 16

245 Pérez, Lara e Romero. Op. cit. p. 99.
} 
A pesar del fracasso, las revoluciones de 1848 lograron, en la Europa occidental, el paso definitivo de las monarquias absolutas a las monarquias constitucionales. La fuerza de la burguesía se hizo evidente, pero también su distancia de los intereses de los obreros. La burguesia había utilizado a los trabajadores en su ascenso al poder político, pero una vez logrados sus fines, se interesó poco por los problemas de los trabajadores y nos los defendió (grifos no original) ${ }^{246}$.

Esse tipo de protagonismo histórico, em que as classes sociais são perfeitamente identificáveis, vai cedendo espaço, nos capítulos seguintes, para um outro tipo de explicação. Deixamos de ver diversos atores em luta dentro de um mesmo país e passam a ganhar relevância os conflitos entre as nações. É no capítulo da Revolução Russa que praticamente vemos pela última vez um processo histórico ser explicado como resultante do enfrentamento de diversos setores sociais. Já no capítulo referente à I Guerra e, mais ainda, naqueles destinados aos temas do período do entre-guerras e da II Guerra, os Estados Nacionais, por meio de seus governantes ou de sujeitos genéricos identificados apenas pela nacionalidade (japoneses, norte-americanos, alemães, etc.) passam a dominar a exposição. Portanto, à medida que as páginas se sucedem, verificase um avanço cronológico que implica em mudança na caracterização dos gentes históricos. Os sujeitos vão perdendo concreticidade, deixam de apresentar um mínimo de enraizamento social, para se tornarem cada vez mais abstrações descoladas de referências para os estudantes, exceto a identificação de suas nacionalidades. Se entre os séculos XVII e XVIII o processo histórico se desenrolava a partir dos conflitos entre o campesinato, a nobreza fundiária, a de toga e a emergente burguesia mercantil, no século XIX esse processo se concentra, a partir de 1870, na ação da burguesia triunfante, ainda que tendo de enfrentar novos antagonistas, o proletariado. Em um terceiro momento, já adentrando ao século XX, esse modelo explicativo dá lugar a um outro, em que a história passa a ser praticamente uma ação dos governantes, das nações, dos Estados. O discurso passa a supor a idéia de povo como uma unidade nacional não contraditória nem conflituosa. 
Somente na última década do século XIX, a França começou a sair de seu isolamento internacional, conseguindo estabelecer um pacto militar com a Rússia em 1894. A Inglaterra se aproximou da França, formando com ela a Entente Cordiale [Você sabe o que significa esses termos em francês?], em 1904, que fundia os interesses comuns dos dois países no plano internacional. A partir de então, as antigas hostilidades franco-inglesas foram esquecidas, para que os dois países enfrentassem um inimigo comum: o sucesso econômico da Alemanha, sua expansão colonial e seu exaltado nacionalismo (grifo no original) $^{247}$.

Isso se acentua de tal forma que a própria seleção iconográfica é afetada: aumenta expressivamente o número de retratos de personagens proeminentes do mundo da política, com destaque para os presidentes ou chefes de governo, que dão face a esses Estados. O mundo do trabalho e mesmo da economia como um todo praticamente desaparece, enquanto as grandes correntes ideológicas como fascismo, nazismo, liberalismo, comunismo - ganham relevância para se explicar os antagonismos entre os povos.

\subsection{A história do século XX: eventos e nações}

Em boa medida essa mudança na definição dos sujeitos históricos se explica pela forma como se aborda o processo histórico. Se os temas relativos ao século XIX envolviam um espaço temporal maior e os temas pareciam melhor definidos imperialismo, revoluções burguesas, etc. com um evidente predomínio de questões econômicas e sociais - à medida que se avança na história do século XX, o evento parece que ganha maior relevância. É preciso apresentá-lo em linhas gerais, definindo seus aspectos mais amplos - o problema, os envolvidos, o desfecho -, mas é igualmente necessário fazer referência a episódios mais específicos, mencionando um fato ou mesmo um detalhe marcante.

A Europa, embora devastada, aderiu à nova ordem bipolar. Na França, após o final da guerra, organizou-se a Quarta República, formada por uma aliança entre os seguidores de Charles de Gaulle, o líder do governo no exílio, e membros dos movimentos da Resistência. O novo 
governo caracterizou-se pela busca contínua da recuperação econômico-financeira e pela divisão e instabilidade interna, produto da diversidade ideológica de seus membros, desde liberais da democracia cristã e social-democratas, defensores de uma ordem capitalista com justiça social, até socialistas e comunistas. Os primeiros alinhavam-se a favor da evolução gradual ao socialismo e os outros a favor de um revolução aos moldes bolcheviques (grifo no original) ${ }^{248}$.

En los anos '60, las naciones del Tercer Mundo descubrieron que el desarrollo económico era una meta muy difícil de alcanzar. La dependencia económica ocupó el lugar dejado vacante por la dependencia política. Los países europeus continuaron explotando los principales recursos naturales y tambien comezaran a decidir las condiciones de los préstamos para esas regiones. En algunas zonas del África subsahariana, como Nigeria y Zaire, se produjeron graves conflictos armados por la presencia de empresas multinacionales que quisieron mantener sus intereses económicos intactos a pesar de los cambios politicos. De esta manera, los países del Tercer Mundo comprendieron que el desarrollo y el subdesarollo eran dos caras dela misma moneda ${ }^{249}$.

Constata-se que o protagonismo histórico passa a ser dos Estados, por meio da ação dos governantes. Esses "personificam" os interesses nacionais. O discurso didático torna-se de fato uma grande narrativa, em que se sucedem, um após outro, episódios e seus personagens centrais, abarcando agora praticamente todo o mundo (não porque tenha surgido subitamente a preocupação de contemplar a história de outros povos, mas porque esses foram subsumidos ao sistema capitalista). Ainda que não perca a perspectiva crítica ou mesmo analítica, parece que o texto deixa de ser propriamente historiográfico e se aproxima mais de um almanaque, ou seja, perde em perspectiva temporal ou histórica. Tornando-se quase refém do evento, essa narrativa exige constante 
"atualização", sob pena de "para no tempo" ou "envelhecer". No dizer de Marco Napolitano, é uma história sem fim ${ }^{250}$.

Talvez essa seja uma armadilha em que o ensino de história esteja caindo: quanto mais valoriza o tempo presente, menos histórico parece ser a natureza do conhecimento desse tempo quando tratado na escola ${ }^{251}$.

Ciro Flamarion Cardoso, pensando essa questão dentro da seara da própria ciência histórica, faz referência às considerações do antropólogo Marc Augé, segundo o qual, na segunda metade do século $X X$, teria ocorrido uma aceleração da história.

O passado se torna história, em nossa época, a um ritmo alucinante: a história corre atrás de nós, está em nossos calcanhares. [...] Há uma superabundância de eventos considerados relevantes, de que somos informados simultaneamente a seu acontecimento, acumulando-se em ritmo rápido demais para sua assimilação ou sua consideração em perspectiva $^{252}$.

Disso decorreria o que Pierre Nora já havia apontado há tempos em um de seus artigos: "a volta dos acontecimentos" ${ }^{253}$. Haveria uma democratização dos eventos, graças aos meios de comunicação, que operam em tempo real, tornando-os imediatamente acessíveis a milhões de pessoas. Mas, ao mesmo tempo, eles vulgarizam e transformam esses acontecimentos, veiculados tal uma crônica policial, gerando o que Augé chama de "paradoxo do evento".

O próprio deslocamento da mensagem narrativa em direção a suas virtualidades imaginárias, espetaculares, parasitárias, que dá a impressão de desvalorizar ou vulgarizar os acontecimentos, permite ao historiador do estritamente contemporâneo inseri-lo numa série. Em

250 Napolitano, Marco E. de. "História contemporânea: pensando a estranha história sem fim". In: Karnal, Leandro. (org.) História em sala de aula. São Paulo: Contexto, 2003, p. 163-184.

251 Sintomático dessa falta de identidade é que boa parte dos conteúdos apresentados nos livros de História referentes ao mundo do pós-II Guerra estão presentes, sem grandes diferenças, nos livros de Geografia. Seria interessante verificar em que medida os alunos conseguem perceber que se trata do "mesmo mundo". Cardoso, Ciro F. Um historiador fala de Teoria e Metodologia.Bauru: EDUSC, 2005, p. 14-15.

253 Apud Cardoso, Ciro. F. ibidem. 
lugar, porém, de procurar reduzir o nível temporal dos acontecimentos - ao que Braudel chamava de 'uma espuma' superficial, algo de menor importância do que as temporalidades mais lentas -, achava Nora que o historiador que se ocupa com a História imediata teria interesse em investir, pelo contrário, no acontecimento utilizando-o como meio para, por seu intermédio, conscientemente, fazer surgir o passado, o espessor histórico, as estruturas, em lugar de, como era habitual no trabalho dos historiadores, fazer inconscientemente surgir o presente no passado (ou seja, projetar o presente no passado). Em outras palavras, os acontecimentos permitiriam evidenciar o sistema, a curta duração revelaria a longa duração estrutural.

Não dispomos de elementos para afirmar que os autores dos livros didáticos partam dessa perspectiva teórica. Entretanto, mesmo sem se darem conta, é o recurso de que parecem fazer uso em suas obras. Cabe perguntar, contudo, como, ou se, isso é apreendido pelo aluno, uma vez que ele naturalmente não dispõe do mesmo repertório conceitual de um historiador. Reconhecer as estruturas nos eventos ou captar a longa duração na curta é uma operação extremamente complexa até mesmo para quem é historiador. Possivelmente esteja nesse ponto uma das principais razões para a grande dificuldade que os alunos alegam encontrar no estudo de História. O grau de abstração dessas explicações é muito elevado (basta ver o número de conceitos empregados), tornando muito difícil atribuir efetivamente um sentido para o que se lê. As aulas, assim, passam a ter peso decisivo, pois sem as explicações do professor os conteúdos são incompreensíveis. Nesse momento instaura-se uma contradição entre os propósitos apregoados sobre como deve ser o ensino e o que ele é de fato. O professor (re)assume o centro da atividade pedagógica, preservando um traço marcante de um modelo de educação que se diz querer superar.

\section{O GRANDE MENTOR}

Naturalmente que para escreverem seus livros, os autores precisam fazer uso de uma bibliografia. Encontramos em todas as obras referências bibliográficas. Nos dois livros brasileiros e também nos dois argentinos, ela é apresentada ao final. Nas duas mexicanas, encontramos ao final de cada unidade uma relação de obras, que serviria também como uma orientação para os 
professores, caso queiram maiores subsídios para suas aulas. As obras citadas variam bastante, desde dicionários, como o de política, de Norberto Bobbio, a textos historiográficos com temáticas específicas, passando por manuais de referência e obras literárias. Em todos encontramos referências tanto a autores marxistas, como Joseph Fontana, E. Thompson e Perry Anderson, como a integrantes da Nova História. Entretanto, é notória a predominância das referências à Eric Hobsbawm.

Sendo um dos expoentes mais conhecidos do chamado marxismo inglês, Hobsbawm, junto com outros autores, alargou a visão marxista em voga até os anos 60 e 70 do século passado. Entretanto, é forçoso reconhecer que nem sempre o alargamento de visão oferecido por eles foi efetivamente assumido pelos autores dos manuais analisados. Ainda que não se possa exigir que os livros didáticos incorporem os múltiplos aspectos que a larga erudição de Hobsbawm articula em seus livros, a verdade é que os autores ainda privilegiam os aspectos econômicos e políticos. Vicentino e Dorigo, por exemplo, praticamente desconsideram os aspectos culturais ao longo das quase 700 páginas do livro, o que não é muito diferente do que encontramos no outro livro brasileiro $^{254}$.

O escritor britânico é, de longe, o mais citado nos seis manuais, tanto em excertos como em epígrafes e boxes complementares. Pérez, Lara e Romero chegam a usar em 5 dos 8 capítulos frases dele como epígrafes, sendo que no capítulo 7 as duas epígrafes são retiradas desse autor. A presença de outros autores marxistas, como Pierre Vilar e Marc Ferro, além dos próprios Marx e Engels, indicam como na literatura didática essa corrente teórica continua bastante influente. Se no passado essa influência chegou ao exagero de esperar que alunos, inclusive do ensino fundamental, dominassem conceitos como modo de produção, relações sociais de produção e ideologia, não parece exagero dizer ainda hoje os livros didáticos veiculam uma concepção de história em que a esfera econômica desempenha grande força explicativa. Mas é ainda mais curioso perceber que essa ênfase no econômico não significou um esvaziamento da esfera do político e, como vimos, do político associado aos acontecimentos,

254 Embora as autoras contemplem em vários momentos os aspectos culturais, eles nunca são os estruturadores de um capítulo, por exemplo. Nos livros argentinos, contudo, o âmbito cultural merece maior atenção. 
herança, como sabemos, de uma historiografia ainda mais antiga. Assim, como observa André Chervel, Cuesta Fernandez e vários outros autores, o ensino de história atual, como também no passado, não é tributário apenas das influências ou mesmo dos modismos - teóricos procedentes da academia. Embora a produção historiográfica tenha importância na definição dos conhecimentos históricos difundidos pela escola, as disciplina escolares também estão atreladas a uma tradição que ela própria cria e consolida. Por isso, apesar de toda a crítica à história política associada aos grandes eventos e aos grandes personagens, ela ainda está presente no ensino escolar dos três países. E a essa " antiga tradição" se juntou uma "nova": a ênfase aos fatores econômicos como definidores dos processos históricos, tradição essa resultante da influência do pensamento marxista entre nós entre os anos 1960 e 1980. E, embora Hobsbawm apareça como o mais citado, ainda predomina na literatura didática um viés economicista, vertente a que não se filia esse historiador inglês.

Pode-se perceber, então, na perspectiva da História da disciplina, algumas mudanças; mas percebe-se, igualmente, quão fortes são as permanências. Talvez se possa ver aqui o que Christian Laville chama de "conforto (ou segurança) da pedagogia tradicional, baseada em uma história para se contar"255, em que uma história feita de uma sucessão de episódios - constituidores de uma grande narrativa - ainda se faz presente. A concepção que se tem sobre o que é valorizar a história do tempo presente, da qual falamos anteriormente, tende a reforçar esse tipo de abordagem, com um agravante, quando tomamos as obras mexicanas e principalmente as brasileiras: como se considera importante que o aluno tenha uma visão abrangente do mundo, os livros apresentam um enorme volume de informações sobre países de todos os continentes, afastando-se de uma perspectiva mais efetivamente histórica e se aproximando de um almanaque (que a cada ano agrega os "últimos acontecimentos"). Decorre daí, pensando especificamente na realidade brasileira, um distanciamento entre a História como disciplina escolar e como disciplina acadêmica, a ponto de muitos historiadores não reconhecerem seu campo de estudo naquilo que é ensinado na escola. Mas como não sabem explicar as razões desse distanciamento, muitos preferem

255 Laville, Christian. "Além do conheciento produzido e disseminado consciência história e educação histórica", p. 10. Trabalho apresentado no IX Encontro Regional da ANPUH, Belo Horizonte, 2002. Texto extraído de www. fae.ufmg.br/ANPUH. 
desprezar os assuntos relacionados ao ensino da História escolar, pois entendem que se trata de uma "outra coisa", diferente do conhecimento que produzem.

\section{DIÁLOGOS COM A ACADEMIA}

Apesar dessas tensões entre o mundo acadêmico e as salas de aula, os livros didáticos denotam a preocupação de seus autores com muitas das discussões travadas pelos historiadores ${ }^{256}$, procurando de algum modo incorporar contribuições de novas pesquisas ou mesmo novas abordagens. Não se trata de tarefa fácil (pois, como vimos, o ensino da história escolar tem objetivos diferentes das investigações acadêmicas) e não raro se verificam atritos em razão das simplificações didáticas feitas em nome da necessidade de levar para o nível cognitivo dos alunos uma certa reflexão. Discutiremos essa questão por meio de duas temáticas: a do cotidiano e da cultura.

\subsection{Cotidiano}

No Brasil, remonta ao final dos anos 1980 a introdução da concepção de cotidiano no ensino de história. Inicialmente essa concepção foi apresentada por meio dos chamados livros paradidáticos, chegando aos didáticos primeiro como seção complementar e, depois, como fundamentação da própria obra ${ }^{257}$. No Ensino Médio, porém, essa abordagem nunca mereceu grande atenção, sendo mais comum encontrá-la nas obras destinadas ao Ensino Fundamental. O presente estudo reforça essa constatação.

Dos seis livros analisados, só dois - um argentino e um brasileiro - possuem uma seção em que o cotidiano aparece como temática explícita. No livro de Myriam e Patrícia, a seção Vida cotidiana em imagens consiste em um painel fotográfico, composto por um número variável de imagens (entre 6 e 9), acompanhadas de legendas que as identificam, acrescidos de comentários

256 Entre outros motivos porque, como dissemos anteriormente, houve época em que os autores eram severamente criticados pelo fato de não acompanharem os debates acadêmicos, incorporando-os aos liros escolares.

257 A coleção Cotidiano da História, lançada pela Editora Ática no início da década de 1980, foi a primeira a apresentar para o público escolar uma abordagem supostamente associada ao cotidiano, fazendo enorme sucesso junto aos professores, com sucessivas edições dos vários volumes. No livro didático, diversos autores introduziram o tema do cotidiano, como o próprio Cláudio Vicentino, em uma antiga coleção para o então ensino de $1^{\circ}$ grau. A coleção História: Cotidiano e Mentalidades, lançada em 1996, foi a primeira se estruturar-se em torno do tema. 
referentes ao âmbito do cotidiano das sociedades estudadas na unidade, que é fechada pela referida seção. Assim, por exemplo, na unidade IV, em que se estudou "Os diferentes povos da América", encontramos lado a lado uma gravura de André Thevet, outra de Jean de Léry, ambas do século XVI, e uma tela (sem data) em que se vê um grupo de pioneiros em "Uma residência do velho do Kentucky", pintura de Eastman Johnson. Não se percebe uma conexão entre as imagens, sobretudo porque a tela aparentemente mostra uma cena do século XIX, em que se destaca, no primeiro plano, uma mulher negra e uma criança. Quando se olha para as demais quatro imagens, a conexão parece ainda mais difícil, pois elas apresentam uma vestimenta sioux, uma pintura maia representando o tradicional jogo ritual com bola, uma máscara asteca e um adereço em ouro inca, constituindo portanto quatro objetos da cultura material mas carregados de sentido simbólico, sem que esse tema tenha sido tratado no capítulo. A religião, quando mencionada, foi sempre associada com aspectos políticos, tanto no caso dos astecas como dos maias e dos incas.

Quando se analisam as oito páginas ocupadas por essa seção ao longo do livro (já que elas, como dissemos, fecham cada uma das unidades), pode-se inferir que entende-se por vida cotidiana qualquer manifestação cultural, desde tomar banho de rio até uma aula em Roma Antiga, passando pelo chorar dos mortos dos guaranis e a criação da pílula anticoncepcional. Portanto, toma-se o cotidiano a partir de uma perspectiva diferente daquela consagrada pela historiografia, que entende o cotidiano como um âmbito das práticas sociais reveladoras da tessitura dessa mesma sociedade, especialmente no tocante à vida privada. O propósito da seção parece ser, então, redimir a obra da pouca atenção que dá à cultura, à vida privada na perspectivas dos vários grupos sociais. Na falta de referências sobre festas, a alimentação, as diversões, os hábitos, os costumes e tradições, incluem-se imagens que de algum modo remetam aos temas.

O cotidiano também serve para fechar um bloco temático no caso do livro argentino, só que de modo mais recorrente, pois ele fecha cada um dos 15 capítulos. Ficamos sabendo, pela seção La organización de este libro que tais páginas apresentam "diversidad de fuentes históricas que documentan la cotidianedad: uma mirada al estilo de vida de cada período de estúdio". E o que 
se entende por estilo de vida? Que estilos foram privilegiados? É bastante difusa essa idéia, porque ela precisa ser apreendida no meio de textos muito diversos: um testemunho da vida em Paris no tempo do Terror, o relato de um viajante a Buenos Aires no início do século XIX, nas considerações de R. Kipling sobre a Índia ou de Simone de Beauvoir sobre os anos 1930 ou do relato de um correspondente da Guerra de Sarajevo no início dos anos 1990. Na verdade, o único ponto comum entre todos é que se tratam de documentos históricos, que relatam aspectos variados da vida de uma perspectiva pessoal, pois as temáticas são muito diversas, incluindo tanto aspectos culturais como políticos e econômicos e é pouco provável, entretanto, que os aluno consigam percebem a unidade entre eles, se é que de fato existe alguma.

A estratégia de se incluir o cotidiano pode ser vista, assim, como uma forma de mostrar um certo aggiornamento com uma tendência que ganhou espaço entre os historiadores e mesmo um público mais amplo nas últimas décadas, dando ao livro e por extensão aos professores a impressão de "atualização historiográfica". Não se vê nenhuma finalidade de cunho mais teórico, de modo a perceber que se pode conhecer a história a partir de um outro prisma. Nesse sentido, a obra elaborada pela equipe de Luciano Privitellio, mais uma vez, avança quando comparada às demais. Sem desprezar os processos econômicos e políticos mais gerais, esses são entremeados por outros aspectos especialmente o da caracterização dos vários grupos sociais e suas experiências, na linha apontada por Thompson e outros autores. Assim, os alunos podem confrontar, por exemplo, a vida de uma família burguesa na segunda metade do seu XIX - seu lar, suas vestimentas, seus valores - com a de uma família de trabalhadores, fazendo uso de quadros da época. Do mesmo modo, quando ao falar do desenvolvimento científico e acadêmico ocorrido na passagem do século XIX para o XX, menciona como a História e a Geografia passaram a compor o campo das ciências. $\mathrm{O}$ surgimento de um grupo mais numeroso de intelectuais naquela época, não só permitia ampliar as reflexões sobre vários campos, alargando os conhecimentos, como ajudava a consolidar um modelo de sociedade assentado na razão e na ciência. Por isso, a transição da sociedade do Antigo Regime para a burguesa não foi apenas marcada pelo fim do poder absolutista dos rei e a ascensão de governantes que atendiam aos interesses da classe emergente. Mais do que isso, tratou-se de mudanças nos valores, pois a idéia de privilégio foi sendo cada vez 
mais combatida ao mesmo tempo que se construía uma idéia de cidadania e democracia, não sem lutas, é claro.

Portanto, tanto no livro brasileiro como no argentino, não é explicitado para o aluno no que consiste propriamente o estudo do cotidiano em História. Fica a impressão de que se tratou mais de uma estratégia encontrada pelos autores para dar conta de aspectos que o capítulo ou a unidade não puderam atender, sem haver, contudo, nenhuma conseqüência pedagógica, pois nada é solicitado ao aluno a partir do texto ou das imagens. O fato de "fecharem" uma seção ou unidade reforça a impressão Caberá ao professor criar alguma atividade, sendo que no caso do livro brasileiro há um complicador: sendo reproduzidas em tamanho pequeno, elas são pouco apropriadas para um trabalho mais cuidadoso de observação. É provável que a seção seja usada por quase nenhum professor

\subsection{Cultura}

A idéia de cultura é seguramente uma das mais debatidas no meio das ciências humanas na atualidade. O conceito é alvo de inúmeras discussões, do qual resultam diferentes conceituações e acepções, além de farta bibliografia. $O$ fato é que nas últimas décadas a idéia de cultura se alargou e passou a ser bastante valorizada pelos historiadores.

No âmbito escolar, tradicionalmente se entende por cultura as manifestações artísticas e literárias - geralmente classificadas entre eruditas e populares - , quase sempre apresentadas, nos livros didáticos, como um corolário das esferas econômica, social e política, ao final dos capítulos ou unidades.

No livro da mexicana Marialba Pastor, a cultura merece referências esparsas ou indiretas. A iconografia do livro é o único recurso que viabilizaria discussões em torno do tema em sala de aula, uma vez que no texto o que se privilegia são os aspectos econômicos e políticos. Por meio das imagens se poderia falar do comportamento e das regras sociais, dos costumes e tradições, da cultura material, apesar de as legendas nada ajudarem. Poucas vezes a autora incluiu na caracterização de um período os movimentos artísticos e intelectuais. Um dos raros casos verifica-se no capítulo 1 da Unidade 6, dedicado à Europa do pósPrimeira Guerra. Nele encontramos os tópicos Los locos años 20 e La revolución 
cultural, no qual se faz referência a Freud e aos movimentos artísticos de vanguarda, como o dadaísmo, surrealismo e cubismo, esses dois merecendo um boxe complementar, o que também ocorre com Arnold Schönberg e suas composições atonais $^{258}$. Antes disso, a autora falara do romantismo, mas abordado exclusivamente como uma reação ao racionalismo, servindo de recurso para explicar o surgimento do nacionalismo e dos movimentos políticos a ele ligado. Do mesmo modo, nas duas vezes que se trata do desenvolvimento científico e tecnológico é para introduzir os dois momentos da Revolução Industrial.

No outro livro mexicano, Pérez, Lara e Romero procuram ampliar essas "janelas" sobre a cultura. Aliás, como mencionamos, entendem que esse é um dos diferenciais da sua obra, pois

[...]se incorporan temas de los que el historiador se ocupa desde hace tiempo, pero que escasamente se encontra en los libros dirigidos a bachirellato, tales como la higiene durante la Idade Media, la visión sobre el adolescente en el siglo XIX, las diversiones en distintas épocas, la participación social de las mujeres, etc., que formam parte de las investigaciones sobre a vida cotidiana a los asuntos de género $^{259}$.

Vale a pena mencionar aqui como "novos problemas e novas abordagens" ingressaram ainda timidamente nos livros. O mundo do trabalho se faz presente, mas quase nunca se menciona o mundo do lazer, da diversão, do jogo e da brincadeira. As crianças praticamente não aparecem, bem como os jovens. Os estudantes nunca são levados a pensar como era a vida de moças e rapazes que tinham a sua idade no século XIX ou no inicio do século XX. Não há festas assim como a morte é pouco mencionada, exceto quando se trata de tragédias, como o holocausto, pestes e guerra. O que impera é a lógica da produção, do capital e das lutas políticas, como se a vida das sociedades ao longo do tempo fosse orientada quase que exclusivamente por isso. 
Uma outra omissão digna de ser mencionada diz respeito às mulheres. Alguns autores praticamente desconsideram a questão de gênero ${ }^{260}$, embora em outros se manifeste um especial cuidado em se inserir com freqüência referências às mulheres, como no caso do livro de Marisa Alonso e equipe, em que se vêem diversas imagens e boxes laterais complementares. Mas é surpreendente constatar que, apesar de todo esse cuidado, quando chegamos à seção Los Protagonistas, o que encontramos são 12 homens, associados a outros 12 indivíduos do mesmo sexo, que lhes servem de contraponto. Ou seja, se no corpo do livro as mulheres foram objeto de atenção recorrente, quando foi preciso eleger os grandes personagens da história contemporânea, só homens mereceram essa chancela. Esse fato pode denunciar duas possibilidades: ou um certo artificialismo na introdução da questão feminina ou o fato de que a seção complementar foi feita por terceiros, que não tinham a mesma preocupação dos autores.

\section{IDENTIDADE: VISÕES EUROCÊNTRICAS}

Mesmo reconhecendo, mais uma vez, que um livro terá sempre e inevitavelmente sérias limitações, e que, quando se opta por uma abordagem abrangente e genérica, do tipo almanaque, só se pode destacar alguns aspectos do processo histórico, é impossível não constatar que a história dos povos asiáticos e africanos, sobretudo desses últimos, é apresentada como totalmente subordinada aos interesses ou aos processos que têm a Europa como centro. Desse modo, asiáticos e africanos só aparecem nos livros quando se estudam as conquistas imperialistas, da qual decorre a partilha de seus territórios a partir de 1870. A única exceção é o caso do Japão, no livro argentino da Puerto de Palos, cuja história merece mais do que um simples menção. O país é tomado como um outro caso de expansão capitalista (tanto assim que ele aparece no capítulo sobre a II Revolução Industrial), constituindo-se em uma das grandes potências da segunda metade do século XIX, apesar das pressões imperialistas européia e norte-americana. Nas quatro páginas dedicadas à história japonesa, há um

260 Vicentino e Dorigo praticamente não dão destaque ao papel social das mulheres ao longo da história, embora a iconografia apresente um bom número de imagens que se vêem mulheres. Marialba Pastor realça apenas uma única mulher em todo o seu livro, Florence Nightingale, cuja atuação na Guerra da Criméia, em 1854, " se habia convertido en un modelo de sacrifício e muchas mujeres se preparon, aunque de manera rudimentaria, para cuidar a los heridos y auxiliar los médicos" (p. 171), ainda que exista um boxe chamado Personajes, em que se toma conhecimento da vida de 21 homens. 
fragmento de um texto de Aizawa Seishisai ${ }^{261}$, denominado Nova Doutrina, com considerações sobre o projeto nacional, uma gravura em que se vê uma mulher com rico traje tradicional japonês e uma outra figura feminina com traje ocidentalizado, uma outra imagem em que se vê a influência ocidental na arquitetura, um boxe citando algumas das conquistas científicas japonesas durante a Era Meiji, uma tabela demonstrando o crescimento do número de operários entre 1896 e 1914, uma outra gravura em que se vê um trem a vapor e grandes embarcações ao lado de um riquixá. Infelizmente, as legendas são muito pouco esclarecedoras das imagens em si, mas de todo modo são bastante ilustrativas do que trata o texto, valorizando-o. No capítulo seguinte, esse sim, sobre o imperialismo, o Japão aparece como uma potência que rivaliza com a Rússia e com os Estados Unidos ${ }^{262}$. Ressalve-se, entretanto, que o protagonismo histórico é do país, não havendo referências sobre os grupos sociais e os conflitos inerentes ao processo de modernização econômica ${ }^{263}$, cujo significado é comparado à independência dos Estados Unidos e à Revolução Francesa, com a diferença de que a Revolução Meiji associou profundas transformações sociais, econômicas e políticas. Ou seja, o espaço conferido à história japonesa possivelmente decorra do fato de que o Japão foi o único país asiático a ter "mudado de lado", ingressando no bloco das potências.

Ainda que somente nos livros brasileiros o tema do imperialismo e do neocolonialismo sejam tratados em um capítulo próprio, sendo nos demais inseridos no interior de um tema mais amplo, verifica-se algumas semelhanças nas abordagens dos livros. Todos os autores destacam que a expansão capitalista decorrente da Segunda Revolução Industrial deflagrou uma nova modalidade de corrida colonial, que não se assentava mais apenas no fornecimento de mercadorias para comércio, mas que entrelaçava interesses econômicos (fornecimento de matérias primas, mercados consumidores e de investimentos), políticos (domínios territoriais) e ideológicos (a missão civilizadora) ${ }^{264}$. No livro

261 Pensador japonês nacionalista, que contribuiu para o fim da dominação Tokugawa em 1868.

262 Alonso, $\mathrm{M}$ et al. Op. cit. p. 89.

263 O texto menciona os conflitos que levaram ao fim do domínio Tokugawa, em que a estrutura feudal associada aos samurais estabelecia privilégios a uma parcela restrita, gerando revoltas urbanas e campesinas. As reformas, porém, foram promovidas a partir de uma aliança ampla, envolvendo intelectuais, samurais, proprietários de terras e capitalistas, visando restaurar o poder do imperador e modernizar o país. Idem, p. 78.

264 Nesse sentido, o desenvolvimento científico da primeira metade do século XIX, o surgimento da teoria darwinista e as concepções do darwinismo social são mencionados em quase todos os livros. 
argentino da Santillana é notável a inclusão de um tópico mostrando que o capitalismo não vivia apenas de um avanço incessante, passando também por fases de depressão, como as verificadas em vários momentos da segunda metade do século XIX. Nesse livro há uma outra distinção interessante, quando se associa o imperialismo ao processo de consolidação dos Estados Nacionais, do qual decorria a exaltação da nação e o nacionalismo. Um componente dessa questão era a territorialidade desses Estados, uma vez que eram eles que definiam a soberania e o pertencimento de um indivíduo a uma dada nação (diferentemente do sistema monárquico anterior, em que a condição política de súdito decorria da subordinação a um monarca e não a um território).

Todos os autores destacam que a corrida colonial foi uma das manifestações de rivalidade entre as potências, dela resultando toda sorte de exploração dos povos colonizados. Não há, contudo, exemplos de como essa exploração se dava mais concretamente.Também são recorrentes as distinções entre as estratégias dos colonizadores, especialmente entre franceses e ingleses. Nos dois livros mexicanos fala-se não apenas desses dois impérios, mas inclui-se também o império russo, o austro-húngaro e o turco otomano. Isso parece decorrer do tratamento que se dará, mais adiante, à I Guerra Mundial, em que o conflito é analisado de modo muito mais detalhado do que nos livros brasileiros, exigindo a compreensão da situação desses três impérios de modo mais profundo. Nesses mesmos livros a idéia central é a de partilha do território africano, mencionando-se os domínios franceses, ingleses, alemães, italianos e belga, sempre com o apoio de um mapa. Portanto, é a lógica do capital - logo, dos europeus - que preside a explicação. Os sujeitos dessa dominação colonial são tratados de um modo muito genérico, ressaltando sempre a exploração de que foram vítimas.

Os Estados Unidos merecem menção em todas as obras, adquirindo, a partir desse momento, relevância. China, Índia, assim como o Japão, são tratados em todos os livros, com destaque para a importância desempenhada pela Índia dentro do império britânico. Mais uma vez o livro do grupo de Luciano Privitellio e equipe se sobressai, ao destacar que essa importância teve aspectos positivos e negativos, pois, 
Como las industrias británicas podían seguir vendiendo sus productos en el Império sin necesidad de modernizarse para competir mejor, sus fábricas se volvían cada día más obsoletas frente a las de otras potencias industriales como Alemania y los Estados Unidos. ${ }^{265}$

A África é tratada de modo ainda mais genérico, apesar de os dois livros mexicanos tomarem um certo cuidado em mostrar a diversidade dos povos que viviam naquele continente. No livro da Oxford encontramos inclusive um boxe que ressalta a riqueza e o desenvolvimento de regiões como a do reino de Tumbuctu, de modo a se evitar o estereótipo de se tratar de uma região pobre e atrasada. Marialba Pastor restringe esse passado de prosperidade ao período anterior ao tráfico negreiro europeu e recorre a generalizações no mínimo questionáveis. No boxe Las civilizaciones africanas lemos:

Antes de que se emprendiera la masiva trata de esclavos africanos en los siglos $X V Y X V I$, en África habian existido grandes civilizaciones como la Ghana, el imperio Mali o el de los songhais en el Niger medio.

Antes de la demanda europea de esclavos, algunos jefes negros orientaron sus actividades a la captura de hombres para obtener a cambio armas de fuego y artículos europeos. Las armas les dieron poder y les permitieron consolidar su autoritarismo. Estos jefes organizaron tribus a lo largo de las costas africanas y, con el fin de submeter a las poblaciones, nombraron sacerdotes que leían el oráculo, advinaban el futuro o realizaban otros tipos de magia.

Algunos pueblos africanos trataron de huir de las "carcerías de negros" y se refugiaron en el centro del continente. La desarticulación de sus antiguas religiones y tradiciones, así como el miedo a la esclavitud, desmoralizó a los africanos e inhibió su interés por desarrollar la agricultura y la manufactura. Se limitaron a sobrevivir con lo que encontraban a la mano o a consumir los productos introducidos por los europeos.

En estas condiciones, el sometimiento de las poblaciones africanas que quedaban "libres" a fines del siglo XIX fue relativamente fácil para los 
europeos., aunque se registraron múltiples resistencias sobre todo de los pueblos musulmanes - al igual que grandes masacres. ${ }^{266}$

Nos dois livros brasileiros, os capítulos destinados ao tema são bastante curtos, especialmente no da editora Moderna, com seis páginas, ante as dez do livro da Scipione. As duas autoras, ao definirem imperialismo, afirmam que ele se manifesta de várias formas ao longo do tempo, sendo a globalização uma delas. Marialba também chama essa fase pós-Segunda Revolução Industrial e do imperialismo de primeira globalização ${ }^{267}$.

Retomando a questão da territorialidade, o apoio de mapas auxilia o estudo do assunto e em todos os livros os encontramos, ainda que com diferenças interessantes. No livro de Myriam e Patrícia encontramos um mapa indicando a partilha de todo o território africano no século XIX e outro com a divisão política mais atual (2002), proporcionando a comparação entre a configuração territorial nos dois momentos. Um terceiro mapa mostra os domínios coloniais na Ásia e na Oceania, ainda que o texto só mencione os domínios franceses na Indochina. No livro da Scipione também vemos um mapa da partilha africana, um outro mostrando os domínios na Ásia entre 1815/1870 conjugado com outro mostrando a mesma área em 1914 e um quarto em que vemos as áreas sob domínio japonês, russo e inglês no extremo leste asiático. O livro dos três autores mexicanos também traz um mapa mostrando a partilha da África ( mas o fato de ser em uma única cor torna sua leitura difícil) e um mapa-mundi mostrando os impérios coloniais em 1914. Já no de Marialba Pastor vemos um mapa-mundi que apresenta os domínios britânicos, com as respectivas datas de conquista, um outro sobre a Indochina e um mapa da África em que se localizam os reinos nativos, os domínios europeus em 1818 (ainda muito limitados) e as expedições de conquista dos vários países, entre 1795 e 1882, mapa esse muito interessante (e pouco usual em obras brasileiras). No livro de Marisa Alonso e equipe há um mapa mostrando a expansão norte-americana pelo Caribe e Pacífico e, na seção Infografia Focal, um mapa-mundi mostra a corrida imperialista. Infelizmente, embora seja uma seção em que o mapa devesse merecer maior destaque, a grande massa de texto, ainda que organizada como legendas, acaba comprometendo o propósito inicial. Tanto assim que, em vez das atividades 
propostas serem de leitura cartográfica, o que se pede é domínio de informação ${ }^{268}$.
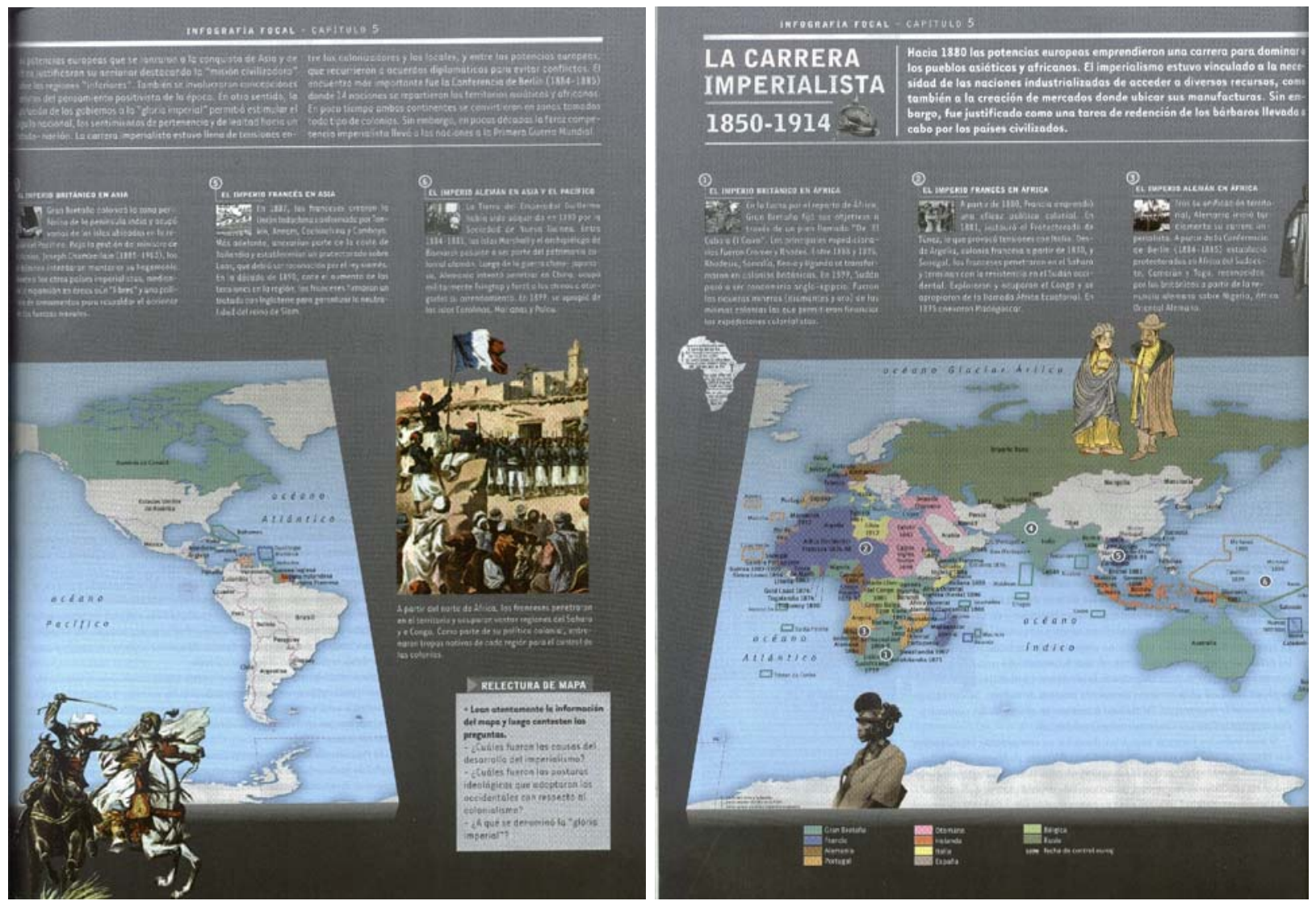

Estratégia parecida, mas com eficiência pedagógica bem maior é o que encontramos no livro do grupo de Luciano de Privitellio. O mesmo mapa com as possessões coloniais, embora visualmente mais simples do que o encontrado nos demais volumes, aparece na seção de atividades, em que se mostra aos alunos como mapas históricos constituem-se em ferramentas valiosas de estudo, uma vez que eles trazem informações por meio de outra linguagem e códigos que podem facilitar a compreensão de um dado tema ${ }^{269}$. Mais do que discurso, quase todas as atividades que se seguem são feitas de modo que as respostas sejam encontradas no próprio mapa, de forma que se associam, uma vez mais, os conteúdos conceituais com os procedimentais, marca dessa seção do livro.

O texto menciona ainda como a cartografia foi um recurso usado para a difusão das novas nacionalidades. "Junto com esta utilidad estratégica, los mapas tuvieron un papel muy importante em la difusión de las nuevas nacionalidades familiarizando a la población con el territorio reclamado como proprio y exclusivo por los estados. La difusión de los mapas imperiales (entre los cuales, uno de los mas conocidos es el 'Mapa Rosa del Imperio Británico') tenia un efecto importante en la población, ya que era una muestra simbólica a más del poderio de la nación inglesa".Privitellio, L.. Op. cit. p. 99. 


\subsection{O lugar da História nacional}

Antes de encerrarmos esse capítulo, gostaríamos de comentar alguns aspectos que nos parecem relevantes no tocante ao lugar da história nacional em livros que abarcam a chamada História geral ou universal.

O primeiro ponto é que nos dois livros mexicanos há uma completa separação de conteúdos, de modo que a História mexicana não é praticamente tratada. Os professores, em sala, podem eventualmente estabelecer relações, mas o fazem sem o apoio dos livros. Subentende-se que há um espaço reservado ao estudo da História pátria, a ser visto em outro volume, em outra série da EdMS.

Já as duas obras brasileiras têm uma concepção distinta, seguindo um modelo chamado de História Integrada. Desse modo, desde a primeira unidade se intercalam capítulos de História do Brasil aos relativos à História Geral, o que se intensifica a partir da emancipação política alcançada em 1822. A intenção, supostamente, é a de realçar as múltiplas relações entre o contexto mundial e o local. Ainda assim, é flagrante a proporção desfavorável para os conteúdos relativos ao Brasil no conjunto da obra. O fato de os capítulos sobre a nossa história serem sempre apresentados depois do contexto mundial, acaba dando a clara impressão de que se trata de uma história subordinada a um processo maior e, por isso mesmo, um tanto quanto "atrasada".

Com relação aos livros argentinos, constata-se que enquanto uma obra, a de Luciano de Privitellio e equipe, preferiu reservar um capítulo dentro de cada unidade para apresentar um tema significativo da história argentina associado ao eixo central da unidade, o outro, do grupo de Marisa Alonso, preferiu privilegiar o estudo da América Latina como um todo, ainda que se façam referências à Argentina. A América Latina também está presente nos livros brasileiros e mexicanos, o que nos faz lançar a questão que nos remeterá ao próximo capítulo: quais são as representações que os manuais analisados trazem sobre a história latino americana? 


\title{
CONCEPÇÃO DE HISTÓRIA: VISÕES SOBRE A AMÉRICA LATINA
}

\author{
¿Para qué voy a estudiar Historia, se un historiador \\ se muere de hambre, como usted?
}

Aluno argentino, cursando o Polimodal

Neste capítulo temos por objetivo identificar nas concepções de história expressas pelos livros analisados a visão sobre a América Latina, de modo a caracterizar o tipo de protagonismo histórico que coube aos povos que vivem nessa região desde a sua independência. Procuro verificar qual o papel e o lugar desses sujeitos históricos no processo de gênese, desenvolvimento e consolidação do capitalismo, que, como sabemos, é o eixo estruturante dos seis livros selecionados. Desse modo, poderemos apreender qual é a identidade latino-americana expressada nos livros.

\section{O LUGAR DA AMÉRICA}

Vem de longa data a crítica sobre o acentuado eurocentrismo verificado nas propostas curriculares brasileiras. Herdeiros de uma tradição curricular francesa, os programas brasileiros durante o século XIX desenvolviam-se em torno de uma história da civilização - uma história essencialmente européia ${ }^{270}$ - e da história nacional. A que tudo indica, foi Rocha Pombo, com um livro publicado em 1900, quem primeiro publicou uma obra visando o ensino de história da América, destinado a alunos do curso Normal. Entretanto, a obra não teve grande público $^{271}$. O tema ganharia um pouco mais de atenção na reforma educacional de 1931, conhecida como Reforma Francisco Campos, portanto já no início da Era Vargas. No texto daquela reforma lemos:

270 Originalmente associado à História Sagrada, os partidários de um ensino de História laico acabaram conseguindo que se implantasse programas cujos conteúdos eram quase exclusivamente relacionados à Europa. Para maiores detalhes, ver Bittencourt, Circe. Livro didático e conhecimento histórico: uma história do saber escolar. Op. cit..

271 Bittencourt, Circe. "O percurso acidentado do ensino de História da América". In Bittencourt, C. e Iokoi, Zilda. Educação na América Latina. São Paulo: Expressão e Cultura/EDUSP, 1996, p. 212-213. 
História do Brasil e da América constituirão o centro do ensino. É claro, porém, que não se deve considerá-las isoladamente. Ao contrário, cumpre seja adquirido, a princípio, o conhecimento da situação do mundo até o descobrimento, para se fazer depois o estudo simultâneo da História Geral, da História da América e da História da Pátria, afim de que possam ser bem apreciadas as influências que concorrem, de toda parte, para a formação do Brasil e de várias nações americanas, bem como para que se considere o papel desempenhado pelos diversos países no conjunto da evolução da humanidade, e se conheçam os problemas humanos em cuja solução cumpre ao Brasil empenhar-se solidariamente com as demais nações ${ }^{272}$.

Apesar desses dispositivos legais, as avaliações a que eram submetidos os aluno do curso secundário privilegiavam os "pontos" de História do Brasil, razão pela qual, segundo Guy de Hollanda, na prática os alunos pouco se dedicavam aos estudos sobre os países latino-americanos. Foi apenas em uma outra conjuntura internacional, nos anos 50, que se formaliza a inclusão de um componente curricular exclusivo sobre a história da América. Contudo, naquele momento, o currículo privilegiava o estudo da história dos Estados Unidos, num contexto marcado pela Guerra Fria e pelo pan-americanismo ${ }^{273}$. Ao longo dos anos 1960, houve escolas que continuaram incluindo em sua programação tais temas, mas, com a entrada em vigor da lei 5692/71, os conteúdos de história de uma maneira geral foram bastante diluídos. Ainda assim, houve espaço para que em alguns estados ocorressem reformas curriculares, como a realizada em São Paulo em 1978, em plena vigência da ditadura, na qual voltou-se a contemplar a história da América, com ênfase para a América Latina. Desde então, ainda que em níveis muito variados, tais conteúdos têm estado presentes nos programas oficiais ou nas propostas curriculares de História, inclusive nos PCNs ${ }^{274}$.

272 Apud Holanda, Guy. Programas e Compêndios da História para o Ensino Secundário Brasileiro. Rio de Janeiro: INEP/Ministério da Educação e Cultura, 1957, p. 19.

273 Cf. Dias, Maria de Fátima. A invenção da América na cultura escolar. Campinas: UNICAMP, 1997. Tese de doutoramento. Também na Argentina o panamericanismo estimulou o estudo em uma perspectiva regional no período pós-guerra, mas por volta de 1976 ela começaria a se romper. Cf. Lanza, Hilda. La enseñanza de la historia en la Argentina de hoy. Tomo III. Buneos Aires: Miño y Davila Editores, 1993, p. 20.

274 Registre-se, contudo, que muitas vezes a inclusão de temas de América nos programas não implica que eles mereçam por parte da maioria dos professores atenção particular. Ao contrário, os sinais são de uma acentuada perda de relevância. 
Mais recentemente, com o mesmo espírito de superar uma história eurocêntrica, e alargar os estudos históricos, foi tornada obrigatória a introdução de conteúdos relativos à História da África nos currículos escolares, de modo que os estudantes conheçam mais e melhor a história dos povos africanos de que nossa sociedade também é tributária ${ }^{275}$. Os livros analisados, por serem anteriores a essa determinação, trazem referências escassas à África, como vimos anteriormente.

Também no México e na Argentina se verificam manifestações críticas frente ao privilegiamento da história européia nos programas escolares ${ }^{276}$, defendendose a necessidade de se alargar, do ponto de vista geográfico, o quadro das sociedades históricas estudadas. Tanto assim que na mais recente proposta curricular argentina é bastante enfatizada a necessidade da inclusão de temas da história da América e, no México, apesar da falta de uma proposta nacional, os livros incluem em alguma medida esses conteúdos.

Muitos argumentos ao longo dos anos foram usados para justificar a ampliação dos estudos sobre povos latino americanos, como, por exemplo, a necessidade de se realçar traços identitários desses povos, cujo passado, desde os tempos coloniais, teria conferido uma série de marcas culturais e históricas comuns, que devem ser não só objeto de conhecimento das novas gerações, mas valorizadas por elas. Diversas iniciativas foram ou continuam sendo implementadas com tais objetivos, dentre as quais podemos citar as da OEI Organização dos Estados Ibero-Americanos, que, entre outras atividades, promove encontros de professores e especialistas latino-americanos, espanhóis e

275 Essa determinação foi estabelecida pela lei 10.639, de 2003.

276 No caso do México, Rocio Romero, por exemplo, menciona o plano de estudos publicado pela SEP em 1993 em que se apresentava uma série de sugestões reorientadoras para o estudo de História, que deveria, entre outros objetivos, " superar el enfoque eurocentrista de la historia de la humanidad que ha predominado en los programas de esta asignatura". Cf. Romero, Rocio Eretza. Estratégias especificas que utiliza el adolescente ante textos de historia en el segundo nível de enseñanza secundaria. México: UPN, 1998, Tesis de Licenciatura en Psicologia Educativa, p. 30. Elvira Vega Monter, porém, considera que na proposta curricular anterior a essa o problema do eurocentrismo parecia melhor contornado, uma vez que a história do México era estudada, nos três anos do curso secundário, em paralelo com a História Universal. Ver Monter, Elvira V. La reforma curricular de 1993 y su impacto en la enseñanza de la historia en la escuela secundaria. México: UPN, 1999, p. 53-54. Hilda Lanza, tratando da Argentina, fala que América Latina está entre aqueles "excluídos ou silenciados" no estudo da História. Ver Lanza, Hilda e Finocchio, Silvia. La enseñanza de la historia en la Argentina hoy.Tomo III. Buenos Aires: Miño y Dávila Editores, 1993, p.23. 
portugueses de modo que se desenvolvam projetos de integração educacional ${ }^{277}$. Com propósitos muito semelhantes, a Comissão de Educação e Cultura do MERCOSUL tem promovido encontros e projetos visando a produção de materiais didáticos que possam ser usados nos países membros, favorecendo a ampliação dos conhecimentos partilhados pelas crianças e jovens dos países que integram esse bloco regional. No bojo dessa iniciativa, por exemplo, teve início em 2001 o Projeto de Integração das Escolas do Ensino Médio do Mercosul. Entretanto, não são poucas as dificuldades a serem superadas para que essas iniciativas de fato mudem o panorama do ensino de historia da América Latina nos países da região ${ }^{278}$. Pelo livro Argentina en la escuela tomamos conhecimento de que naquele país não são poucas as tensões e os conflitos que envolvem a inclusão de temas relacionados à história de países vizinhos, como Chile e Brasil ${ }^{279}$. Liliana Brezzo, em um artigo publicado em 2001, fala da persistência de um notável desconhecimento da realidade paraguaia por parte dos estudantes argentinos, apesar das mudanças nas relações diplomáticas entre os dois países nas últimas décadas $^{280}$. No México, a situação não é muito diferente, embora os problemas mais sérios ocorram com relação ao seu vizinho do Norte ${ }^{281}$.

\section{A AMÉRICA LATINA SOB A ÓTICA DOS LIVROS MEXICANOS E BRASILEIROS}

A história da América Latina é contemplada nos seis volumes analisados, mas varia muito o número de temas incluído em cada livro. As abordagens dadas e o grau de profundidade dos estudos são também bastante diversos.

277 A título de exemplo podemos mencionar o Projeto de Ensino da História da Iberoamérica, que, depois de analisar os currículos na região, propôs, em 1999, um currículo modelo, que deveria servir de guia para os professores. Essa instituição publica anualmente vários livros em torno do tema, inclusive obras destinadas aos alunos, como é o caso da coleção "La historia de Iberoamerica desde los niños", que contava em dezembro de 2005 com 4 volumes.

278 Já tivemos oportunidade em outro lugar apontar algumas dessas dificuldades. Ver Silva, Vitória R. "O ensino de história da América no Brasil". In: Diálogos Revista do Depto. de História do Programa de pós-graduação em História da Universidade de Maringá. Vol 8, no. 2, 2004, p. 81 a 103.

279 Romero, Luis Alberto (coord.). La Argentina en la escuela - la Idea de nación em los textos escolares. Buenos Aires: Siglo XXI, 2004.

280 Brezzo, L. "El Paraguay y la Argentina en los textos escolares: una perspectiva bilateral de las representaciones del outro". In Entrepasados Revista de História. Ano VI, no. 12, 1997, p.186.

281 Em meados dos anos 90, por iniciativa da OEl, se realizou um estudo de modo a se superar os modelos nacionalistas ou patrióticos de se estudar a História, propondo-se mudanças curriculares e na elaboração dos livros didáticos. No caso do México, especificamente, o documento mencionava o esforço de moderação dos livros mexicanos quando se estudava o expansionismo norte-americano. Vázques, Josefina Zoraida e Aizpuru (comp.) La enseñanza de la História. Washington, apud Brezzo, L. Op. Cit. Idem, ibidem. 
Os livros mexicanos são os que menos espaço reservam a essa temática. Pérez, Lara e Romero abrem um sub-tema, no capítulo 4, dedicado à independência da América Latina, no qual se traça, antes, uma rápida caracterização da sociedade colonial e se explica a crise da qual decorreu o processo de emancipação das colônias, incluindo aí o caso do Brasil ${ }^{282}$. Um mapa serve para mostrar como ficou a divisão política dos países bem como a data em que eles lograram sua independência. No capítulo seguinte, dedicado à expansão imperialista das potências européias, há um sub-tema que trata da região durante o século XIX, mostrando como foi o processo de consolidação dos estados nacionais recém-formados, ocorrido concomitantemente à penetração do capital estrangeiro. Outras - poucas - referências à América Latina encontram-se em meio ao capítulo dedicado à Guerra Fria, não havendo referência alguma no capítulo final, que trata do mundo globalizado, exceto uma brevíssima menção ao México, como exemplo da parcialidade das regras de livre comércio $^{283}$. Fica evidente que os autores preferiram privilegiar em seu livro os temas relativos à história da Europa e, em menor grau, dos Estados Unidos, denotando que esses seriam os mais relevantes para a compreensão do mundo contemporâneo por parte de um estudante mexicano. Lembremos que naquele país, no segundo ano do bachillerato, os programas prevêm conteúdos exclusivamente ligados à história mexicana. Assim, com exceção da Revolução Cubana, da crise dos mísseis nesse mesmo país e do golpe militar no Chile (que pôs fim ao governo socialista de Allende), esses jovens não tomam conhecimento de nenhum outro fato histórico da região relativo ao século XX por meio desse livro. Mesmo questões recorrentes nos outros livros analisados, como populismo e ditaduras militares, não são analisadas nessa obra.

No livro de Marialba Pastor abordam-se os mesmos temas, mas de modo ainda mais resumido, notando-se também algumas diferenças no tocante à história dos Estados Unidos ${ }^{284}$. Assim, o primeiro capítulo dedicado ao estudo da região tem

282 Antes, na página 87,os autores abordaram as sociedades pré-colombianas.

283 Trata-se, no caso, dos problemas enfrentados pelos motoristas de caminhões mexicanos entre os anos de 1997 e 1999, quando os Estados Unidos alegavam o descumprimento de normas administrativas e sanitárias para justificar a proibição da entrada de seus veículos naquele país. Pérez, Lara e Romero, Op. cit. p. 297. Marialba dedica um capítulo à colonização e independência dos Estados Unidos; um outro, denominado El imperio norteamericano, aborda a escravidão, a Guerra Civil, a expansão econômica e colonial até o estabelecimento da política conhecida como Big Stick. O capítulo 3 da Unidade 6 é em boa medida dedicado também aos Estados Unidos, abordando a Crise de 29 e o New Deal. Já o livro de Pérez, Lara e Romero aborda a independência das 13 colônias, a ascensão dos Estados Unidos como potência capitalista no século XIX, incluindo referências sobre a expansão territorial e a Guerra Civil, a Crise de 29 e a grande depressão, além de diversas menções ao país no tocante à II Guerra, Guerra Fria e à globalização (capítulos 6, 7 e 8). 
por tema as independências das colônias espanholas e da colônia portuguesa (capítulo 1 da unidade 3). Um tópico do capítulo 3 da unidade sobre o Entreguerras fala dos reflexos da depressão dos anos 1930 na América Latina, região novamente abordada no capítulo que fecha a Unidade 8, em que se trata das experiências socialistas, da presença do grande capital, das ditaduras e das guerrilhas entre os anos 1950 e 1990. Apesar de muito reduzidas as referências sobre a região, a maneira como a autora encerra esse tema, ao final desse capítulo merece menção:

Pese a las señales de cambio, el establecimento de la plena democracia en América Latina está condicionado a la superación de grandes problemas, muchos de los cuales se arrastan desde la época colonial:

- La monopolización del poder político por los caciques, las bueguesias locales o las dictaduras militares y presidencialistas.

- El nacionalismo promovido por las oligarquias.

- La dependencia de las burguesias nacionales y sus mercados hacia Estados Unidos de América.

- El poco ahorro y la excessiva deuda externa contratada por los gobiernos.

- La falta de diversidad de productos para la exportación.

- La escassez de créditos e inversiones en la industria pesada

- La fuga de capitales para su inversión en el extranjero o en la especulación.

- La desigual distribuición de la riqueza.

- El bajo nivel de vida de los obreros.

- La extrema miseria en el medio rural y en los suburbios de todas las grandes ciudades.

- El latifundismo abierto o encubierto.

- El éxodo del campo a la ciudad.

- El desempleo o subempleo.

- La pervivencia de la servidumbre doméstica.

- El analfabetismo.

- El burocratismo. 
- El incumplimieto de las leys, la corrupción y el creciente aumento de la violencia ${ }^{285}$.

É com esse cenário, homogêneo, sombrio e que não leva em conta as mudanças havidas desde os anos $1990^{286}$, que a autora encerra suas considerações sobre a América Latina, o que por certo ajuda a consolidar a percepção de que vivemos em uma região cujo futuro, mais do que incerto, parece muito pouco promissor. Diante de tal número de problemas, e da gravidade de todos eles, como pode um jovem acreditar que os povos latinoamericanos podem almejar um futuro melhor? A proposição de uma atividade, a última na seção de exercícios, solicitando que o aluno analise esses problemas e formule propostas para solucioná-los não parece reverter essa percepção, por mais idealista e voluntarista que seja um adolescente de 16 ou 18 anos. Impotência deve ser a sensação mais forte ao final do estudo. A julgar por essa autora, o velho dilema de Sarmiento - civilização ou barbárie -, tragicamente, parece ainda se perpetuar, indicando que as representações daquele autor do século XIX continuam em voga.

A autora também preferiu reservar maior espaço para a história européia, fazendo referência a outras regiões do mundo sempre em função de processos orientados a partir daquele continente ou dos Estados Unidos. O fato de encontrarmos referências esparsas sobre os povos latino-americanos nos dois livros mexicanos, faz supor que naquele país os professores não valorizam a inclusão desses temas como critério para a seleção do livro adotado. Aqueles que se preocupam com tais temas precisam eles próprios elaborar seus materiais, já que encontram pouco subsídio nos livros didáticos.

É um pouco diferente a realidade brasileira. Por abarcarem um espaço temporal maior, encontramos maior número de capítulos e/ou temas relacionados à América Latina nos livros analisados. Eles tratam do início da ocupação humana de nosso continente e, no caso do livro de Myriam e Patrícia, inclui-se um capítulo sobre as sociedades americanas anteriores à chegada dos europeus (unidade 3),

285 Pastor, Marialba. Op. cit. p. 275

286 Ainda que se possa fazer muitas críticas às "reformas" que tiveram curso nas últimas décadas, a autora toma a América Latina como uma realidade quase petrificada, desprezando as mudanças verificadas nas últimas duas ou três décadas, que deram à região novos contornos. 
unidade também composta por um capítulo sobre as 13 colônias inglesas e outro sobre a América espanhola. Ambas as obras dedicam um capítulo à independência dos Estados Unidos e outro à emancipação das colônias ibéricas. Vicentino e Dorigo reduzem apenas a esse aspecto a história relativa ao século XIX dessa região, uma vez que ela só é retomada no (longo) capítulo 41, que abarca desde a instauração da Guerra Fria até os anos 1990, em um tópico denominado A América Latina e as lutas sociais ${ }^{287}$. Nele se fala do México (desde a Revolução Mexicana até o movimento de Chiapas, nos anos 1990, tudo em duas páginas), do Chile (do governo Allende até o processo que Pinochet foi submetido no ano 2000), da América Central (Canal do Panamá, Revolução Sandinista, intervenção norte-americana no Haiti e, num deslize geográfico, do Peru, além de breves comentários sobre as idéias reformistas neoliberais na região durante os anos 1990). Todo o texto é orientado segundo o eixo que estrutura o capítulo, ou seja, está a serviço do tema do mundo bipolarizado da Guerra Fria ${ }^{288}$. O resultado, portanto, é um mosaico fragmentado e superficial, cabendo ao professor complementar o texto, caso considere relevante oferecer uma visão mais aprofundada e articulada dos fatos apresentados, muito diversos entre si $^{289}$.

Chama atenção, em ambas as obras, o mesmo tom negativista, apontando inúmeros problemas e o fato de os setores conservadores dominarem totalmente o cenário político. Vicentino e Dorigo referem-se a alguns acontecimentos em que o protagonismo coube a setores populares, como por exemplo o movimento zapatista no México, o do Sendero Luminoso e o Movimento Revolucionário Túpac Amaru, ambos no Peru. Mas como o objetivo principal é o de denunciar a continuidade dos graves problemas sociais que marcam toda a região (que se reportam desde os tempos coloniais), parece inevitável concluir que esse é um fardo eterno a que os povos latino americanos estão submetidos.

\footnotetext{
287 Vicentino, C. e Dorigo, G. op. cit. p. 588.

288 É por isso que a Revolução Cubana é mencionada quando se aborda o governo Kennedy, momento também em que há referência à Aliança para o Progresso. Vicentino, C. e Dorigo, G. op. cit. p. 570.

289 Esse é um bom exemplo das escolhas que os autores de livros didáticos precisam fazer, dado número limitado de páginas que dispõem para tratar de um certo conjunto de temas. Os autores nesse caso preferiram o que estou chamando de abordagem de almanaque: menção a um grande número de países e personagens, ainda que de modo superficial, ficando a cargo do professor o aprofundamento ou não. Retomo a questão mais adiante.
} 
Myriam e Patrícia, de modo semelhante, abrem um capítulo - inserido entre aquele que tratou do processo de independência e o que abordará mais adiante as experiências socialistas de Cuba, Chile e Nicarágua -, em que tratam da economia e da política durante o século XIX. O conceito central é caudilhismo ${ }^{290}$, que merece, inclusive, o mais longo boxe-glossário de todo o livro, ocupando toda uma coluna, tendo o verbete sido extraído da Encyclopédia Britannica. E o que informa o glossário?

Elemento dominante na vida política dos países da América Latina, o caudilhismo substitui, em sua área de influência, os regimes constitucionalmente estabelecidos e torna sem efeito as medidas decididas pela sociedade em favor da vontade do líder.

Caudilhismo é a forma de exercício do poder político que se caracteriza pelo agrupamento de uma comunidade, ou de importante parte dela, em torno do caudilho, líder que exerce o mando de maneira autoritária. O sistema se caracteriza pelas relações pessoais do caudilho com seus adeptos, dificilmente transferíveis em caso de desaparecimento do primeiro. O caudilhismo pode envolver relações de índole militar, nos casos em que o caudilho ascende ao poder como chefe de grupos armados.

Em alguns momentos históricos, os caudilhos representaram, embora sem coerência de idéias e magnanimidade nos atos, os anseios populares de melhora de vida e liberdade pessoal contra os interesses oligárquicos. A primeira geração de caudilhos chegou a incluir alguns próceres da independência das colônias hispano-americanas. O caudilhismo apresentase, no entanto, como forma de exercício de poder radicalmente oposta à democracia. O caudilho não recorre ao apoio expresso ou à aprovação do grupo que dirige, por considerar natural e evidente sua liderança.

290 No capítulo 35, quando se tratou do processo de emancipação política das colônias espanholas, as autoras já haviam introduzido o conceito, usando a definição de Norberto Bobbio extraída de seu Dicionário de Política, segundo o qual, " o caudilhismo representou em certos casos, a defesa das estruturas socioeconômicas tradicionais, como também o artesanato e a indústria incipiente, contra as elites burguesas que atuavam na exportação de matérias primas, constituindo a típica burguesia compradora. Na América Latina, o termo continua sendo usado, como o de cacique, para designar chefe de partido local ou de aldeia com característica demagógica". Essa última consideração nos remete, naturalmente, ao conceito de populismo, sobre o qual falaremos a seguir. Mota, M. e Brasick, P. Op. cit. p. 315. 
O caudilhismo surgiu na América Latina por volta de 1820, em decorrência da passagem inesperada e brusca do regime colonial para a independência $[\ldots]^{291}$.

O leitor não é muito auxiliado por essas explicações. Visto o que ele estudou em capítulo anterior, como dizer que o processo de independência tinha sido inesperado e brusco, fato que explicaria o surgimento de lideres políticos personalistas e autoritários que sobrepõem sua vontade aos desejos ou projetos da sociedade? Como é possível que um líder político despreze seus liderados, fazendo uso apenas da força, e ainda assim consiga se manter no poder? Sabemos que, apesar de haver sérias divergências políticas entre os grupos conservadores e liberais, as idéias de república e sobre as vantagens dos regimes constitucionalmente estabelecidos estavam bastante consolidadas no seio da elite latino-americana ao longo do século $X X^{292}$. Além disso, não procede a afirmação de que onde vigoraram práticas caudilhescas inexistia uma ordem constitucional, como demonstram, por exemplo, o caso argentino. Além disso, não fica claro o que significa dizer que em alguns momentos os caudilhos representaram os anseios populares de melhoria de vida e liberdade frente aos interesses oligárquicos, ainda que isso se desse "sem coerência de idéias e magnanimidade nos atos".

O leitor deve ficar ainda mais desconcertado quando lê, quase ao final do verbete, que "a depressão econômica que se seguiu às lutas de independência teve influência decisiva para a expansão do caudilhismo", já que um pouco antes ele havia sido informado de que "a emancipação da América Latina trouxe efeitos benéficos para os grandes exportadores dos produtos primários, que controlavam a economia da região. Os detentores dos meios de produção - ou seja, os donos das terras - implementaram mudanças significativas na organização de seus latifúndios, como a adoção de novas técnicas produtivas" ${ }^{293}$. Fica bastante evidente que o glossário discrepa do próprio texto das autoras. Se tal texto viesse na forma de uma leitura complementar, essa discrepância poderia se pedagogicamente interessante, fazendo com que os alunos o criticassem. Mas

\footnotetext{
291 Mota. Myriam e Braick, Patrícia. Op. cit. p. 393. Textos. São Paulo: EDUSP, 1999, especialmente o capítulos 2 e 3.

293 Mota, M. e Braick, P. Op. cit. p. 392.
} 
certamente não é essa a função de um glossário, que cumpre papel de ferramenta de estudo para o leitor.

É interessante observar ainda a incoerência subjacente à explicação das autoras no tocante à exclusão dos setores populares na vida política das novas nações latino-americanas, se considerarmos que também na Europa as idéias de república e igualdade eram duramente refreadas pelos grupos conservadores. Tanto no Velho como no Novo Mundo, o século XIX foi marcado pelos inúmeros enfrentamentos para a incorporação ao jogo político e à prática efetiva da cidadania de largos setores socialmente marginalizados até então. Não deveria causar estranheza se na América setores dominantes assumissem postura elitista e vissem com reservas os ideais democráticos uma vez que no início do século XIX não existia lugar que não fosse assim. Como argumenta Maria Lígia Prado,

A defesa da limitação dos direitos políticos passa por uma perspectiva ilustrada e elitista própria dos liberais do século XIX, tanto na América Latina como na Europa. Não quero estabelecer qualquer tipo de generalização abstrata, mas apenas lembrar que na Europa, nessa mesma época, havia um intenso debate sobre a questão da soberania popular no campo ideológico liberal, com a proposição de uma série de mecanismos legais para evitar a "perigosa" participação política popular. Esses limites só puderam ser superados pela efetiva luta dos grupos impedidos de alcançar a cidadania naquele momento. ${ }^{294}$

O fato de as idéias democráticas não serem implantadas não quer dizer que não estivessem no horizonte dos setores populares, mesmo quando esses fossem "étnica e culturalmente muito diferente da elite". Aliás, isso pode ser depreendido do texto usado como suporte da argumentação das autoras, ainda que pareçam querer dar um outro sentido a ele:

Não é preciso reafirmar que a construção da democracia na América Latina tem sido extremamente difícil e que a plena cidadania das classes populares ainda precisa ser conquistada. Para se pensar esse tema, o período posterior à independência política na América Espanhola é particularmente 
interessante de ser estudado. A construção dos Estados Nacionais significou um longo processo de lutas sociais e políticas, em que se confrontaram adversários poderosos, muitas vezes acompanhados de longas guerras civis, envolvendo grande parte da sociedade, de abastados fazendeiros a pobres peões. A emergência de aspirações sociais divergentes, numa época de mudanças institucionais, ainda fez aparecer no cenário político um intenso debate, entre sujeitos, política e ideologicamente opostos, sobre temáticas fundamentais, como federalismo, laicização do Estado e a democracia $[\ldots]^{295}$.

Ao longo do século XIX, havia diferentes sujeitos históricos lutando por diversos projetos políticos em toda a América Latina. O fato de uns saírem derrotados não quer dizer que não tenham lutado, diferentemente, portanto, do que dá a entender as autoras quando afirmam, em frase que antecede a citação acima, que "nas sociedades em que a classe baixa era composta por indivíduos culturalmente muito diferentes da elite hispânica, praticamente não existia a possibilidade de os setores populares se envolverem ativamente na política"296. Recorrendo mais uma vez a Maria Lígia Prado, devemos considerar que

[...] a questão da democracia e do direito à cidadania só pode ser entendida à luz da análise de situações históricas específicas, com ênfase na questão das lutas sociais e dos conflitos políticos que as envolvem. Se buscarmos explicações a partir de conceituações genéricas, como a dependência ou a herança colonial, estaremos presos a um esquema preconcebido que nos dará a priori as respostas que buscamos. Creio ser importante observar que as justificativas elaboradas por esses liberais do século XIX, foram, posteriormente, apropriadas para instituir uma certa perspectiva do "atraso" e do "despreparo" dos setores populares para o exercício da democracia, o que acabou transformando-se em "verdade" inquestionável, "fruto do passado histórico da América Latina". ${ }^{297}$

Constata-se pois um fato especialmente curioso: as autoras fazem uso de um texto muito recente, escrito por uma especialista no tema, que procura em seu

295 Prado, Maria Lígia Coelho. América Latina no século XIX: Tramas, Telas e Textos, apud Mota, Myriam e Braick, Patrícia. Op. cit. p. 392.

297 Prado, Maria Lígia Coelho. Op. cit. p. 91. 
texto rever uma série de estereótipos sobre a formação dos Estados Nacionais e no entanto o texto é usado com propósito exatamente inverso, uma vez que é invocado para reforçar idéias bastante consolidadas no senso comum sobre a vida política das nações latino-americanas durante o século XIX.

Voltemos ao verbete. Lemos ao final dele:

O declínio do caudilhismo deu-se nas primeiras décadas do século $\mathrm{XX}$ com o influxo da imigração européia, a industrialização, a reforma eleitoral e a profissionalização do exército. Esse último fato, no entanto, favoreceu a implantação de ditaduras militares em pleno século $X X$, como ocorreu no Brasil, Argentina, Bolívia, Uruguai, Haiti e Peru ${ }^{298}$.

O trecho é exemplar, pois sintetiza em cinco linhas uma representação bastante consolidada no senso comum sobre quase dois séculos da história latino-americana: do caudilhismo ${ }^{299}$ ao populismo e deste para as ditaduras militares. Constata-se, assim, que apesar do mérito de se buscar a inclusão do estudo sobre a história da América Latina, ele mais reforça estereótipos do que ajuda a jogar luz sobre os intrincados caminhos desse percurso histórico. Além disso, as generalizações encobrem situações históricas muito diversas, o que também não contribui para que se construa uma outra imagem sobre a região.

\section{POPULISMO}

Imigração, industrialização, reforma eleitoral de que fala o verbete acima mencionado são os componentes centrais de outro conceito chave quando se explica a história da América Latina: o populismo. Myriam e Patrícia afirmam que

\footnotetext{
298 Idem, p. 393.

299 No caso desse livro, não há uma clara distinção entre caudilhismo e regimes oligárquicos, podendo mesmo dizer que eles se confundem. "A postura das elites latino-americanas, que sempre transpuseram as leis em benefício próprio, acabou desencadeando reações populares que levaram ao fortalecimento do Executivo e, conseqüentemente, à implantação de ditaduras militares ao longo dos séculos XIX e XX. Essas ditaduras foram apoiadas por caudilhos, líderes político-sociais que comandavam o poder local e rural (semelhante ao "coronel" brasileiro presente na República Velha). A montagem do Estado oligárquico nas ex-colônias espanholas da América percorreu, na maioria das vezes, processos parecidos com a formação do Estado brasileiro." Mota, Myriam e Braick, P. Op. cit. p. 393.
} 
após a grande depressão dos anos 30, a América Latina enfrentou profundas mudanças econômicas, sociais e políticas [...] que acarretaram a queda dos governos oligárquicos. O momento em que surge o populismo coincide com o início do processo de urbanização e industrialização. $\mathrm{Na}$ verdade, pode-se dizer que o populismo latino-americano resultou da crise do poder das oligarquias agrárias. Porém, o populismo é um fenômeno estritamente urbano que se alimenta dos mesmos ingredientes que sustentam as oligarquias agrárias - ou seja, a falta de cultura, a pobreza e a desinformação.

As autoras continuam, dizendo que nem por isso o período populista é irrelevante; ao contrário, em alguns países ele é dos mais importantes, como é o caso do peronismo na Argentina, sobre o qual elas tratam de modo muito resumido. Os casos mexicano (com Cárdenas), boliviano (com Paz Estenssoro) e equatoriano (com Velasco Ibarra) são apenas citados, distinguindo o primeiro caso, em que os populistas chegaram ao poder por meio de eleições, dos dois outros, que ascenderem ao pode pela via revolucionária ${ }^{300}$.

É curiosa a associação de idéias que fazem as autoras. Ao abrir esse capítulo, que compreende os governos entre 1945 e 1964 e cujo título é Os especialistas em planejamento, elas inserem um trecho de entrevista em que a historiadora Carla Anastasia observava, em 1990, como o governo Collor surgia com "um novo populismo", com marcados traços autoritários, em que se procurava ressaltar o papel de "salvador da pátria", de modo que gradativamente forjava-se um mito em torno daquele presidente. A entrevista, observe-se, foi dada muito antes da votação do impeachment. As autoras começam o seu texto afirmando que a dita entrevista demonstra como ainda hoje se verifica na América Latina o fenômeno de alguns líderes políticos próximos às massas conseguirem extraordinária popularidade.

Para ilustrar as primeiras considerações sobre o tema, foi colocada uma foto do então candidato presidencial Fernando Henrique Cardoso, montado a cavalo e usando um típico chapéu nordestino de couro. A legenda diz: 
Beijar criancinhas, cumprimentar trabalhadores, aparecer ao lado de artistas, comer um prato local, tomar um trago de cachaça, etc: táticas populistas ainda muito comuns no Brasil, principalmente em época de eleição. Fernando Henrique Cardoso monta a cavalo durante a campanha presidencial, em 1994, na região nordeste ${ }^{301}$.

É clara a intenção de demonstrar, tanto com o texto de abertura como com a foto, que ainda hoje se presenciam práticas herdadas do populismo em nosso país (cabendo perguntar, entretanto, se é pertinente associar Fernando Henrique com populismo), procurando estabelecer relações entre o passado e o presente. É com o mesmo propósito que elas afirmam no tópico que tem por título Populismo e inclusão social que:

O político populista "autêntico" tem de fato um projeto de inclusão social, ainda que este muitas vezes se realize de forma ineficaz ou paternalista. Um exemplo desse tipo de procedimento é a proposta de implantação de restaurantes e hotéis a preços populares, que em 2002 serviu de bandeira para a campanha do político fluminense Anthony Garotinho à Presidência da República. Também vale lembrar que foi no governo de Vargas que a legislação brasileira deu largos passos rumo à proteção dos interesses do povo trabalhador. Assim, ainda que adotem posturas e discursos próximos ao populismo, os políticos conservadores que atuam em benefício direto das classes dominantes não podem ser rigorosamente enquadrados na categoria populistas. O político paulista Paulo Maluf encaixa-se nesse perfil $^{302}$.

O populismo "autêntico" se confunde, no texto, com um supostamente "falso", deixando o leitor um tanto aturdido: no mesmo parágrafo menciona-se Garotinho, Vargas e Maluf, sem que fique claro qual é mesmo o líder populista "autêntico". O mesmo tópico é concluído com a afirmativa de que na história recente da América Latina políticos com discursos populistas continuam ocupando cargos importantes. Entra então um texto relativamente longo (uma coluna), sobre o 
presidente venezuelano Hugo Chávez, caracterizado como um "perfeito exemplo de político populista em ação no século XXI”303.

O próximo tópico destaca como os governos populistas surgiram em meio a um cenário que era marcado, por um lado, pela "euforia e otimismo democrático" e, por outro, pela Guerra Fria. Além disso, verificava-se a expansão do sistema capitalista na América Latina, com a penetração do capital monopolista, o que fazia com que qualquer atitude tomada como nacionalista fosse associada como

sintoma de uma conspiração comunista internacional. É nesse cenário que surge, em alguns países da América Latina - Brasil, Argentina, México, Bolívia, Peru e Equador - o estilo de governo populista. ${ }^{304}$

Myriam e Patrícia assim os caracterizam:

Esses governos adotaram um comportamento paternalista e autoritário: ao mesmo tempo em que concediam direitos aos trabalhadores, mantinhamnos sob estreita vigilância e controle permanente. Assim, essa pratica política reproduzia as contradições existentes nos países latino-americanos, divididos entre a sociedade rural oligárquica e o mundo urbano burguês.

Por essas razões, os governos populistas apoiavam-se em bases sociais heterogêneas: seu apoio partia de setores do empresariado nacional, das classes médias e do operariado. Nesses países de industrialização tardia, era comum o discurso nacionalista que apontava a espoliação dos grupos estrangeiros como elemento causador do subdesenvolvimento. No entanto, esse discurso configurava uma contradição, uma vez que grande parte de suas políticas econômicas era financiada pelo capital estrangeiro, notadamente o norte-americano.

O parágrafo seguinte começa com uma discrepância temporal:

No Brasil o populismo teve início nos anos 1930, na Era Vargas, e chegou ao fim com os governos militares, a partir de 1964. Nomes como Getúlio 
Vargas, Juscelino Kubitschek e João Goulart fazem parte da galeria de presidentes populistas ${ }^{305}$.

Em meio a essa exposição, cita-se ainda uma passagem de um texto de Ângela de Castro Gomes em que a historiadora apresenta uma das interpretações clássicas sobre o populismo, segundo a qual essa prática política representaria um "estado de compromisso", envolvendo uma classe dirigente em crise de hegemonia, classes populares que pressionam por uma maior participação política e um líder carismático, cuja atuação transcende partidos e instituições. Embora saibamos que essa autora não veja o populismo desse modo ${ }^{306}$, é esse o conceito que, no final, fica para os alunos, no meio de tantas ambigüidades presentes no capítulo: Vargas é ou não populista? O populismo começou no Brasil em 30 ou é um fenômeno decorrente da Guerra Fria? Toda prática paternalista e autoritária de líderes políticos populares e carismáticos é populismo? Inclusão social é ou não é componente central do populismo?

É muito interessante constatar que, a despeito disso tudo, na seção de atividades, peça-se ao aluno, como primeiro exercício:

\section{Defina, com suas palavras, o que é populismo ${ }^{307}$.}

Como será que os alunos se saem diante de tal indagação?

O que fica muito evidente nos dois livros brasileiros é que, apesar das boas intenções dos quatro autores em dar maior atenção à história da América Latina, ela é abordada de maneira totalmente subalterna aos países centrais:

As independências políticas latino-americanas não resultaram em desenvolvimento socioeconômico autônomo, e sim em dependência em relação aos centros dinâmicos do capitalismo, especialmente Inglaterra, no

\footnotetext{
305 Idem, Ibidem.

306 Ângela de Castro Gomes, assim como muitos outros historiadores, consideram o populismo como uma modalidade de prática política comum em diversos países que experimentaram um rápido processo de modernização, em que setores emergentes da sociedade, especialmente os trabalhadores urbanos, passaram a ter maior atuação política, tanto com o propósito de garantir direitos anteriormente adquiridos, como ampliá-los. Ver, entre outros trabalhos dessa autora, Gomes, Ângela de Castro. A invenção do trabalhismo. Rio de Janeiro: Vértice/luperj, 1988.

307 Mota, M. e Braick, P. Op. cit., p. 508.
} 
início, e Estados Unidos, a seguir. No final do século XIX, este país, já então poderoso economicamente e acompanhando o expansionismo imperialista europeu, impôs seu controle geopolítico sobre boa parte dos assuntos americanos, processo que se completaria no início do século seguinte ${ }^{308}$.

Certos de adotarem uma perspectiva crítica, eles encadeiam uma seqüência histórica em que os povos latino-americanos nunca realizam um projeto próprio: a independência foi resultado dos interesses britânicos; o caudilhismo foi a expressão da continuidade da opressão política dos tempos coloniais, só que agora executada por chefes políticos violentos e sanguinários, que conduziam uma massa amorfa e totalmente submissa aos desígnios desses comandantes locais. Essa triste realidade política foi substituída por outra, mais "moderna" e urbana - o populismo -, reflexo mecânico de um processo de industrialização artificial, porque resultado da penetração de capitais estrangeiros (multinacionais), interessados apenas em explorar as riquezas da região e a mão-de-obra barata disponível. Vicentino e Dorigo chegam mesmo a dizer:

Pode-se dizer que Getúlio Vargas inaugurou [em 1930] o populismo no Brasil, como prática política que desmobiliza politicamente a população. Apesar de (ou por isso mesmo) buscar satisfazer suas necessidades mais imediatas, sem promover conscientização.

O populismo vem acompanhado de grande dose de paternalismo, que marca a política brasileira até hoje. O líder é visto como alguém que dá coisas, concretas ou não, de alimentos e itens de vestuário a empregos, que presta favores à população. Assim, é natural que aquele político que dê mais passe a ser o mais querido. Nesse papel, a propaganda passa a ser decisiva, como bem percebeu Vargas. [...]

No momento da construção do governo revolucionário e durante os seus primeiros anos no poder, o presidente fez apelos às classes trabalhadoras

308 Vicentino, C. e Dorigo, G. Op. cit. p. 324. É curioso que os autores caem em contradição dois parágrafos abaixo, quando afirmam que "os criollos, membros das elites hispano-americanas, desejavam romper com a metrópole monopolista, que lhe dificultava as operações mercantis, sobretudo com a Inglaterra, principal pólo econômico do mundo. [...] Criollos e ingleses tinham, portanto, interesses comuns, que convergiam para o mesmo objetivo: a independência das colônias espanholas na América". 
urbanas, acenando-lhes com a possibilidade de criar benefícios e até leis favoráveis. $^{309}$

Ou seja, os setores populares estão sujeitos a toda sorte de manipulação política, não possuem mínima consciência da sua situação de classe e por isso são vítimas de lideranças populistas, que apenas com acenos e promessas conseguem iludir largos setores sociais. Anos depois, quando o populismo acentua o seu caráter de política de massas e, por isso mesmo, havia transbordado para além dos limites do tolerável, vieram as ditaduras.

É interessante observar que em ambos os livros a associação entre populismo e a ditadura militar só se faz com relação ao Brasil, quando se explica o golpe de 64. Vicentino e Dorigo não fazem referências ao populismo quando tratam do caso mexicano, tampouco em outro momento do tópico destinado à América Latina durante a Guerra Fria. Myriam e Patrícia, por escolherem apenas os casos de Cuba, Nicarágua e Chile (as experiências socialistas) também não fazem nenhuma associação entre o acirramento dos conflitos sociais e a instauração dos regimes militares, o que envolveria a retomada do conceito de populismo. Chega a ser curioso verificar que Myriam e Patrícia destacam que os argumentos usados pelos oponentes de Jango para justificar a deposição do presidente foram "que as medidas do governo punham em risco as bases do capitalismo no país e o poder hegemônico dos Estados Unidos no continente" ou o perigo vermelho. ${ }^{310}$ Nesse sentido, a questão do populismo fica "perdida" no tempo e as transformações que a industrialização promoveu, com o surgimento da política de massa, deixa de ser relevante.

Caracterizam-se, pois, os dois livros por adotarem explicações bastante esquemáticas; entretanto, ainda que se reconheçam todas as limitações inerentes a um livro didático, pelo número de páginas que precisa ter e o cronograma que dispõem os professores, essas deficiências não se justificam. Prova disso vemos nos livros argentinos.

\footnotetext{
309 Vicentino, C. e Dorigo, G. Op. cit. p. 525-526.

310 Mota, M. e Braick, P. Op. cit. p. 506.
} 


\section{CAUDILHISMO E POPULISMO NAS ABORDAGENS DOS LIVROS ARGENTINOS}

Vejamos em primeiro lugar o que diz o grupo de Marisa Alonso. Como há dois capítulos inteiros para tratar da América Latina durante o século XIX - 0 primeiro, abarcando o período entre 1810 e 1850 e o segundo envolvendo o intervalo entre 1850 e 1914 -, o processo histórico é abordado de modo mais detalhado. Nesse primeiro capítulo, procura-se explicar as lutas pela independência recorrendo a uma periodização: o primeiro e o segundo ciclo revolucionário. Ainda que não se explicite marcos temporais que separem um ciclo do outro, depreende-se que o primeiro corresponderia aos anos de 1810 e 1815 e o segundo entre 1815 e 1824. É quando se trata do segundo ciclo que aparece pela primeira vez o conceito de caudilho que, porém, só é explicado duas páginas depois:

En algunas regiones, los enfrentamientos se plasmaron em guerras civiles que sucedieron al proceso independentista y que llevaron a primer plano a los caudillos. Estos dirigian milicias rurais que respondían mas a sus jefes que al Estado, lo que dificultó la unificacíon política al exacerbar el regionalismo ${ }^{311}$.

Nas páginas seguintes os autores têm o propósito de demonstrar aos alunos como, entre os anos de 1810 e 1850, diferentes projetos políticos procuraram se instaurar, com destaque para o caso argentino e para a luta de Bolívar, explicando os diversos fatores que inviabilizaram seu projeto de unidade política.

No outro capítulo, que corresponde ao período entre 1850 e 1914, a exposição continua tendo por objetivo demonstrar o enfrentamento de vários grupos sociais, articulados em torno de alianças (proprietários rurais e militares $x$ grandes comerciantes e setores urbanos) e portadores de diferentes projetos políticos. Um boxe lateral, ainda no primeiro dos dois capítulos, informara que, durante as guerras pela independência, entre os "patriotas" havia aqueles que defendiam um modelo centralista (um governo central forte, que submetesse as províncias), os que preferiam o sistema confederado (conferindo grande autonomia às províncias, cabendo ao governo central escassos poderes) ou ainda 
um modelo intermediário, em que se conciliava autonomia local e determinados poderes ao governo central ${ }^{312}$. Constata-se, porém, que no texto expositivo só encontramos referências aos federalistas, identificados depois como localistas, e aos centralistas, posteriormente caracterizados como unitários. Mas advertem os autores que, essa divisão logo deu lugar a uma outra, entre conservadores e liberais. Os primeiros se associavam aos antigos valores hispânicos, como tradição, família e religião, enquanto os liberais eram propensos a defender idéias tidas como modernas. Mas havia ambigüidades entre os adeptos dessas correntes, assim como em cada país podem ter adquirido características próprias, como na Argentina, onde os liberais eram favoráveis a um estado forte, enquanto no Brasil defendiam maior descentralização ${ }^{313}$. O objetivo último dos autores com tal argumentação é ressaltar que, ainda que se reconheçam algumas diferenças entre liberais e conservadores, sobretudo no tocante à separação entre Estado e Igreja e à maior valorização dos indivíduos frente às instituições, no fundo ambos os grupos defendiam posições elitistas, que apenas reforçavam o caráter oligárquico dos regimes vigentes na região ${ }^{314}$. Ainda que se detenham em marcar diferenças, ao final ficam bastante diluídas as tensões desse período, tão intenso da vida política latino-americana. Desse modo, quando explicam as transformações que ocorreram entre 1850 e 1914 (recorte temporal bastante problemático para esse estudo) ${ }^{315}$, sustentadas nas idéias positivas ou cientificistas em vigor na época, o que se sobressai são basicamente dois aspectos: a antiga dominação da elite metropolitana é substituída pela dominação da elite criolla, favorecida pela maior inserção dos países latino-americanos no mercado mundial; e a antiga dominação econômica espanhola dá lugar à dominação britânica, grande beneficiada ao garantir novos mercados para a sua indústria, fontes de matéria primas e alimentos baratos, além de assegurar locais para investimento de seus bancos. Não fica, contudo, esclarecido como países

312 Idem, p. 37.

313 Idem, p. 102.

314 Nesse sentido, ao separarem em dois momentos o estudo sobre o século XIX, parece bem mais clara a distinção entre a fase de predomínio dos caudilhos, quando das guerras de independência, e a fase oligárquica, quando os Estados Nacionais estão mais consolidados e os embates centrais se dão entre liberais e conservadores, "herdeiros" políticos dos centralistas e federalistas.

Considero a periodização problemática porque, do ponto de vista didático, a estrutura dos capítulos seguindo as 4 seções (los hechos, el contexto económico y social, etc.) obriga a um ir e voltar temporal que remete a duas conjunturas bastante distintas: uma primeira em que predominam na região as atividades agrárias e um segundo momento em que a industrialização e a urbanização levam à configuração de uma nova realidade histórica. Quando se refere ao Brasil essa oscilação torna-se ainda mais problemática, como veremos mais adiante. È provável que isso seja um complicador para a compreensão dos alunos. 
agrário-exportadores começam a se industrializar, mencionando-se apenas um desejo de modernização por parte de certos grupos sociais. O máximo que se afirma é os que governos promoveram reformas liberais que facilitavam e davam garantias para novos investimentos estrangeiros, dos quais resultaram transformações econômicas relevantes. Não se explica, entretanto, o que motivou essas reformas e que grupos internos com elas se beneficiaram. Tem-se a impressão que tudo decorria exclusivamente do poderio das potências imperialistas européias, que se beneficiavam dessa situação para explorar as fragilidades dos países americanos. O protagonismo histórico, portanto, não cabe aos latino-americanos, mas a sujeitos externos, que os conduzem segundo seus interesses e vontades $^{316}$, o que os aproxima das abordagens brasileiras.

Nesse sentido, os mexicanos Pérez, Lara e Romero formulam uma explicação mais coerente e convincente, ao demonstrar que, em meio ao processo de expansão imperialista, estabelece-se uma aliança entre grupos internos e o grande capital:

Em los primero años de vida independiente los países latinoamericanos ofrecían gran atractivo para el capital europeo. Sin embargo, las luchas civiles imperantes implicaban riesgos, por lo que las ctividades económicas de los europeos en la region se restringieron. Por otra parte, a mediados del sigo XIX persistia en Latinoamérica una economia agrária. Si bien había inversiones en la mineria y el comercio, el monto total de capitales se destinaba a la tierra, pues se considera la única fuente segura de riqueza. De modo que en América Latina habia un capitalismo con un desarrollo escaso y atrasado.

Si embargo, la nuevas generaciones de la burguesia, de acuerdo con el esquema del liberalismo económico, promovieron el progreso mediante sus respectivos gobiernos. Aun aí los proyectos resultaron limitados y no fue sino a partir de la década de 1870 cuando los intentos modernizadores se intensificaron, pues en ese momento convergieron los intereses de

316 Outro indicativo dessa concepção se percebe quando analisamos a seção Los protagonistas: dos 24 personagens que constituem essa seção, mesmo destinando quase metade da obra ao estudo da América Latina, apenas dois são dessa região: Bolívar e San Martín. Os números são mais contundentes quando comparamos com os nove norte-americanos e seis europeus, sendo três deles russos (N.Kruschev, M. Gorbachov e B.Yeltsin). Portanto, não são apenas as mulheres, como mencionamos anteriormente, que não são destacadas, mas os líderes latinoamericanos igualmente, denunciando uma das mais sérias incoerências ou contradições verificadas nessa obra. 
crescimiento de las burguesías latinoamericanas con las necesidades del gran capital en el comienzo de la fase imperialista.

Los gobiernos dictariales de América Latina, que representaron los intereses de las burguesías locales, abrieron sus puertas a la inversión de capitales externos. $[. . .]^{317}$

Ressalte-se ainda o mérito dos autores em explicar a relação entre os aspectos econômicos e políticos, em que as lutas entre conservadores e liberais acabaram por fazer com que as idéias liberais se consolidassem na maior parte da região, ainda que com particularidades, como a implantação de governos ditatoriais. Aliás, o conceito de ditadura tem maior relevância do que o de caudilhismo no texto desses autores. Também merece destaque o fato de os autores mostrarem que não era apenas os Estados Unidos que exercia uma política mais ativa na região, uma vez que diversos conflitos entre os vários países marcaram a segunda metade do século XIX, como a Guerra do Pacífico e a Guerra do Paraguai. Portanto, os conflitos e as tensões se davam em três níveis: interno, entre os países latino-americanos e entre esses e as potências imperialistas. Em nenhum outro livro isso fica plenamente caracterizado.

Voltando ao texto do grupo de Marisa Alonso, seria arrematado disparate negar que de fato a Inglaterra encontrou nos mercados latino-americanos grandes oportunidades para rentáveis negócios. Mas é simplismo inaceitável, mesmo para efeitos didáticos, reduzir tudo à manutenção da mesma ordem de exploração (do antigo colonialismo para o neocolonialismo), que, quando muito, promoveu a alteração da nacionalidade dos exploradores. A realidade da região em 1850 é bastante diferente daquela verificada em 1914, como o próprio texto demonstra nas seções el contexto econômico y social e temas y paradigmas. Se havia grupos social e economicamente privilegiados em ambos os momentos, por certo não eram exatamente os mesmos, assim como não eram os mesmos os sujeitos históricos que se enfrentaram em cada uma das épocas, defendendo cada qual os seus projetos. Ainda que os autores insiram no segundo capítulo considerações sobre o grande contingente de imigrantes que ingressam em vários países da região e o surgimento de indústrias, por meio das quais aparecem os operários, 
há uma dissonância entre o cenário político, aparentemente marcado pela imobilidade, e o econômico e social, muito mais dinâmico.

Apesar disso, é notável a diferença entre essa obra Argentina e as analisadas anteriormente. Ainda que, como mencionamos, a periodização abarcada no capítulo facilite confusões ${ }^{318}$, há um esforço grande em mostrar aos alunos como durante a segunda metade do século XIX a configuração histórica em diversos países latino-americanos foi se transformando profundamente: a vida nas cidades foi se tornando mais agitada, não só por causa das indústrias e do conseqüente movimento operário, mas também porque se diversificavam as opções de lazer, como o futebol e o teatro; serviços marítimos favoreciam o transporte de mercadorias e pessoas, facilitando os movimentos migratórios, assim como as ferrovias encurtavam os caminhos internos; a presença norteamericana se fazia cada vez mais forte, a Revolução Mexicana alertava para os problemas fundiários que afetavam mais diretamente a população indígena e mestiça; o poder da Igreja era cada vez mais contestado, aprofundando a separação entre ela e o Estado. Enfim, a América Latina também procura modernizar-se, o que implicava em disciplinar os setores populares por meio da difusão de uma cultural comum. A escola, então, passou a assumir um papel fundamental, ao difundir valores de civismo e contribuir para a construção de uma identidade nacional, e o papel repressivo do Estado se acentua, como se viu na Revolta da Vacina, tema que merece um boxe ${ }^{319}$. O modo como os vários grupos sociais atuam é exposto de forma muito diferente das demais obras, tornando menos abstrata a situação histórica encontrada nessa época, ainda que, do ponto de vista político prevaleça uma imagem de estabilidade quando não de conservadorismo, entendendo-se por isso a permanência dos antigos grupos dominantes no poder.

318 Isso fica muito evidente quando se trata do Brasil, que merece duas páginas inteiras. Como em 1850 há o fim do tráfico negreiro, em 1888 ocorre a abolição da escravatura e no ano seguinte há a Proclamação da república, a estrutura do capítulo, que implica em um ir e voltar temporal, deve confundir bastante os alunos. Desse modo, depois de tratar na seção Los echos da mudança de regime político, em 1889, na seção seguinte fala-se da economia cafeeira e da importância do tráfico negreiro, texto ilustrado por uma gravura de Rugendas e, inexplicavelmente, por uma foto mostrando um grande proprietário peruano ao lado de um numeroso grupo de empregados (uma foto muito interessante, mas reproduzida em tamanho muito pequeno). Mencione-se ainda que o fim do tráfico é datado como uma decisão do imperador, em meados da década de 1850, atribuindo-se como causa desse fato a ascensão ao poder dos liberais. Ver Alonso, M. et al. Op. Cit. p. 106 e 113 
Mas esse cenário de relativo imobilismo político muda quando se ingressa no novo período, entre 1914 e 1945, marcado pelo populismo. Nesse capítulo identificam-se dois vetores explicativos das transformações. Por meio do primeiro, explica-se como a partir da I Guerra Mundial a supremacia britânica na região foi sendo substituída pela norte-americana. Uma tabela comparativa dos investimentos dos dois países em 1913 e 1929 demonstra essa transição, ainda que em termos de valores absolutos, as inversões inglesas fossem ainda substancialmente maiores do que as norte-americanas, especialmente na Argentina e no Brasil.

Por meio do segundo, demonstra-se como as transformações econômicas redundaram em modificações das estruturas sociais de modo que a ordem oligárquica era crescentemente combatida, tanto por setores populares (operários e camponeses) como por setores médios urbanos. Disso decorre, por um lado, a intensificação do movimento operário (dividido em várias correntes ideológicas, originárias da Europa), e, por outro, o surgimento de projetos reformistas antioligárquicos, em que se destaca o caso argentino (quando se verificou o domínio do Partido da União Cívica Radical, entre 1916 e 1930). Dois outros países merecem destaque: o México, com seu processo de consolidação da Revolução de 1910 (até a eleição de Cárdenas em 1934) e do Peru, onde se viu a implantação de um modelo político de corte autoritário.

O capítulo segue tratando da política externa norte-americana (intervencionismo, panamericanismo e política da boa vizinhança), em que uma nova tabela indica todas as intervenções feitas por Washington entre os anos de 1898 e 1933, em cada país da região, o que exemplifica de modo muito contundente os argumentos do texto.

Depois de apresentar Los hechos, a seção El contexto econômico y social começa explicando como a crise de 1929 afetou diretamente toda a região e é nesse novo cenário de depressão que vão surgir os movimentos nacionalistas populistas, em que os governantes procuram conter a efervescência crescente do movimento operário. Encontramos, então, uma primeira definição de populismo. 
La mayoría de los gobiernos latinoamericanos surgidos a partir ade 1930 fueron caracterizados como populistas. Sin embargo, el término populismo nunca fue claramente definido. A pesar de los desacuerdos, la postura mayoritaria lo presenta como una ideologia que supo capitalizar las demandas planteadas por los sectores populares contra los viejos regímenes oligárquicos que marginalizaban de la política a las grandes mayorias.

Esta definición general sirvio para agrupar a las diversas experiencias políticas que tuvieron lugar en latinoamérica y que compartieron características comunes a pesar de la diversidad goegráfica, cultural y económica de la región. Por otro lado, a grandes rasgos, la fórmula populista fue útil a la hora de nombrar a aquellas naciones que constituyeron gobiernos empeñados en el desarrollo de un nuevo modelo económico y que emplearon un tipo de discurso dirigido a las grandes masas con el objeto de atraer su apoyo. Pero sobre todo, intentaron obtener el favor de las masas trabajadoras en su lucha por el control del Estado.

En otro sentido, la gran mayoría de las experiencias populistas tuvieron en común sus límites, debido a que no buscaron alterar las relaciones de poder en favor de la organización autónoma de las fuerzas populares. Lejos de esa postura, intentaron convertirse en una herramienta eficaz para controlar el cambio social. Si bien la mayoria de los líderes populistas latinoamericanos se daclararon antiimperialistas y anticomunistas, prevaleció en ellos un mayor empeño por erradicar las ideas de izquierda, lo que en ocasiones les restó el apoyo de un sector de la sociedad, como los intelectuales o los obreros afiliados a los partidos socialistas y comunistas, quienes se convertieron en furiosos opositores a esos regímenes. ${ }^{320}$

O trecho nos possibilita observar importantes diferenças na abordagem histórica. Em primeiro lugar, os autores chamam a atenção para o fato de não haver uma definição única para populismo, mostrando que os historiadores têm divergências sobre esse conceito, havendo, portanto, um debate, por meio do qual vai se constituindo o conhecimento histórico. Apesar das divergências, há um certo consenso, o que possibilita agrupar uma série de experiências, uma vez que elas possuem alguns traços semelhantes: a luta dos setores populares contra a

320 Alonso, M et al. Op. cit. P. 194. 
ordem oligárquica então vigente. A generalização não impede de se registrar o fato de tais experiências também terem suas especificidades. Por se tratar de movimentos reformistas, o populismo enfrentava forte oposição de setores da esquerda, denotando que o movimento operário estava longe de ser homogêneo e apenas uma massa de manobra, como vimos em outro texto.

O cenário histórico do período entre 1914 e 1945 é complementado com outras considerações de ordem econômica (maior preocupação com o mercado interno, processo de substituição de importações) e também de ordem social e cultural, como o surgimento da cultura de massa: a difusão do rádio e do cinema, dos quais emergem os primeiros ídolos populares, como Carlos Gardel e Libertad Lamarque, além das diversas modalidades esportivas, especialmente o futebol e beisebol.

No capítulo 13, que abarca o período entre 1945 e 1973, retoma-se o conceito:

El populismo fue uno de los principales fenómenos políticos por el que atravesron los países latinoamericanos durante el siglo XX. Estos gobiernos se caracterizaron por el desarrollo de políticas nacionalistas y antiimperialistas, y sus principales apoyos provinieron de los sectores medios y trabajadores. Las primeras experiencias se produjeron en los inicios del siglo. Por entonces, se trató de un tipo de populismo llamado liberal, que se apoyó en la ascendente clase media y cuya propuesta reformista puso el acento en la ampliación de la participación política de dichos sectores. Algunos ejemplos de este modelo fueron Hipolito Yrigoyen, en la Argentina y Alessandri, en Chile ${ }^{321}$.

Os autores seguem a exposição, classificando o populismo em duas modalidades: o clássico e o tardio. O primeiro tipo ocorreu entre as décadas de 1930 e 1940, quando os líderes mobilizavam grandes massas urbanas em torno de programas nacionalistas e, em alguns casos, socialistas. Associavam políticas voltadas para os trabalhadores, visando o bem-estar social, e antiimperialistas, ainda que buscassem o crescimento industrial. Seriam exemplos do populismo 
clássico os governos de Haya de la Torre (Peru), Gaitán ${ }^{322}$ (Colômbia), Cárdenas (México), Betancour (Venezuela), e Perón (Argentina). O populismo tardio ocorreu nas três décadas seguintes, e apresentava características distintas, uma vez que as condições econômicas dos países tinham se alterado negativamente, impedindo o restabelecimento das alianças entre os setores trabalhistas e empresariais. O aparecimento de um operariado de origem rural, a maior participação de mulheres e jovens no mercado de trabalho "comezaron a desbordar los canales de institucionalización de sus demandas" ${ }^{\text {"323. }}$. Alguns líderes populistas se inclinaram à direita enquanto outros foram para esquerda, ao mesmo tempo em que as Forças Armadas assumiam maior protagonismo no cenário político, do que resultou a erradicação do populismo em quase todo a América Latina. A tentativa de periodizar - fase liberal, fase clássica e fase tardia - ajuda o aluno a compreender que se trata de um mesmo fenômeno mas que teve variações ao longo do tempo.

Muito diferente, portanto, da ambigüidade temporal verificada no livro de Myriam e Patrícia, de que falamos antes. Além disso, no livro argentino a explicação que se dá para o surgimento dessas práticas está melhor fundamentada, subsidiando compreensão das contradições e conflitos verificados nas sociedades daquela época e não mencionando apenas que elas existiam. Alguns aspectos políticos são aprofundados, ainda que agora o populismo apareça na seção Los hechos. E, tal como ocorrera no capítulo anterior, os casos brasileiro e mexicano mereçam destaque.

Os autores argentinos reservam mais de meia página para tratar especificamente do caso brasileiro, sob o título "Getúlio Vargas: entre el totalitarismo y el populismo". Abarca-se o período em que Vargas governou como um todo, incluindo, inclusive o período democrático (1950-1954) e, incorre-se em um erro, pois se afirma que a ascensão de Vargas em 1930 já marcaria o início do Estado Novo, sob inspiração dos regimes totalitários de Salazar e Mussolini ${ }^{324}$. Fala-se que graças ao apoio norte-americano o Brasil se tornou durante a

322 Observe-se a imprecisão factual, uma vez que nem Haya de la Torre nem Gaitán assumiram os governos de seus países, ainda que fossem líderes importantes.

323 Alonso, M. et al. Op. cit. p. 238

324 Idem, p. 239. Curiosamente, no capítulo 10, as informações dadas são corretas, explicando que Vargas ascende ao poder em 1930, dá um "autogolpe" em 1937, quando tem início o Estado Novo. Idem, p. 196. 
Segunda Guerra um país de vital importância como provedor de borracha e quartzo, redundando daí o financiamento por parte dos Estados Unidos de grandes obras de infraestrutura. No final da guerra, Vargas teria dado uma guinada populista, enfatizando o perfil proletário de seu governo; mas o ressurgimento da oposição, que passou a pressioná-lo levou à sua renúncia. Voltaria à presidência, em 1950, consagrado com 48,7\% dos votos.

A grandes rasgos, el tercer mandato de Vargas [sic] se caracterizó porque sufrió grandes dificultades políticas y econômicas, en un contexto donde la alta inflación y al déficit em la balanza de pagos se les sumaron denuncias de corrupción que lo dejaron en total aislamento político. En 1954, ante el pedido de dimisión presentado por los altos jefes militares, Vargas optó por suidarse y dejó como testamento una carta en la que acuso de su fracaso a fuerzas antipopulares externas e internas ${ }^{325}$.

O tópico seguinte trata do governo de Lázaro Cárdenas no México, mencionando igualmente sua política na área do petróleo e da reforma agrária ${ }^{326}$. Registre-se que no capítulo anterior, foram feitas referências ao governo de Cárdenas, entre 1934 e 1940, salientando que durante esse período a classe operária mexicana organizou-se em torno da Confederação dos Trabalhadores do México, instituição que contou com o incentivo Cárdenas e era comandada por um líder comunista (Lombardo Toledano), que também promoveu a organização dos camponeses em uma confederação própria. Essa organização levou à ocorrência de greves e pôde oferecer apoio ao presidente quando esse começou a ser pressionado a anular nacionalização dos recursos naturais do país. Portanto, nota-se um tipo de protagonismo dos setores populares nesse texto que não é verificado nem nas obras brasileiras nem nas mexicanas.

O capítulo abrange ainda um leque amplo de temas, como a intervenção norte-americana na Guatemala, a Revolução Cubana, a Aliança para o Progresso, a criação da CEPAL e a formulação da teoria da dependência, o governo Allende e o golpe de estado no Chile. Ao se delinear El contexto económico y social, a economia, mais uma vez, é marcada por grandes transformações, em que o grande capital internacional aparece com destaque, por subordinar o 
desenvolvimento interno às suas necessidades. É nessa tensão entre a busca de um crescimento autônomo e a presença do capital estrangeiro, da qual decorrem conflitos políticos entre setores nacionalistas e grupos associados aos interesses estrangeiros, que se desenvolvem os conflitos políticos que, em vários casos, redundam em golpes militares. São exemplos as ditaduras no Brasil, Argentina e Chile, onde se configuraram uma sólida aliança conservadora, da qual faziam parte setores das Forças Armadas, da Igreja, grupos empresariais ligados às multinacionais, com o principal propósito de combater a influência comunista na região. A Doutrina de Segurança Nacional, alertando para o perigo da subversão interna, justificava a adoção de políticas de repressão aos opositores dos regimes, em que se destacavam os movimentos guerrilheiros e mesmo setores progressistas da Igreja católica. Por outro lado, foi nesse mesmo cenário que transcorreu a Revolução Cubana, num dos mais importantes confrontos com o imperialismo norte-americano. O capítulo se fecha mostrando, de um lado, a revolução sandinista na Nicarágua e, de outro, a Operação Condor, em que regimes militares da Argentina, Chile, Bolívia, Paraguai e Uruguai (não se inclui o Brasil), organizaram um sistema inteligência para a troca de informações estratégias visando a repressão política. Ou seja, não há um destino selado para os povos latino-americanos, como a lista de problemas a serem superados apresentados pela mexicana Marialba Pastor faz crer. A mesma conjuntura internacional deu margem a experiências tão diversas como a mexicana, a chilena e a cubana. A sofisticação da abordagem desse livro quando comparada aos demais chega a ponto dos autores apresentarem as idéias cepalinas e a teoria da dependência, mostrando como se pensou e se explicou a América Latina a partir de dois modelos teóricos distintos. Impossível não concluir que são muito maiores as oportunidades que os alunos argentinos encontram de construir uma imagem mais complexa da região ao estudarem por esse livro.

No último capítulo destinado à América Latina, o décimo quinto (e que fecha o livro) ficam evidentes mais uma vez os inconvenientes de se estabelecer cortes cronológicos únicos para a organização do livro. Afinal, em 1973, quando o capitalismo começa a enfrentar um período de grave crise, o cenário na América Latina não se altera, ainda que a recessão mundial the afete. O impacto ocorreria mesmo a partir do final dos anos 1970 e início dos anos 1980, quando as ditaduras militares foram dando lugar a regimes democráticos e reformas 
econômicas começaram a ser implantadas, em razão do agravamento das dívidas externas. Diversas temáticas se repetem sem muita justificativa, como a Aliança para o Progresso, a Doutrina de Segurança Nacional, o governo Allende e a Revolução Sandinista ${ }^{327}$. Agora o foco é demonstrar como a adoção de modelos neoliberais, associada aos impactos da globalização, deram uma nova configuração à região, sem que isso representasse a superação de antigos problemas, como se observa no caso do movimento de Chiapas, no México ${ }^{328}$. Questões gerais são abordadas como o desemprego, o trabalho temporário e o papel do Estado frente a esse cenário; as novas tecnologias, em especial nos meios de comunicação e nos processo produtivos (transnacionalização); o enfraquecimento dos Estados Nacionais, a homogeneização da cultura, novos papéis das mulheres e o movimento feminista. Sobre esses dois últimos tópicos, vale ressaltar dois aspectos mencionados: o da mudança do sentido do termo popular, que agora se confunde com consumo de massa e não se associa mais às tradições do povo (confrontando com a idéia do capítulo 10, quando se falou do surgimento dos primeiros ídolos populares no rádio e cinema, como Carlos Gardel), denunciando o açambarcamento definitivo da cultura pelo mercado; e as singularidades do movimento feminista no Terceiro Mundo em geral, e em particular na América Latina, onde só muito recentemente as mulheres passaram a lutar mais efetivamente por igualdade de direitos. Esses dois exemplos demonstram mais uma vez como nesse livro se vai muito além das esferas política e econômica, limitação clara dos dois livros brasileiros e dos dois mexicanos, ainda que em menor medida no livro de Pérez, Lara e Romero.

Passemos agora para o livro Historia del mundo contemporâneo, da equipe de Luciano de Privitellio. Ele segue um caminho diverso, pois não há capítulos

327 No capítulo anterior, a Revolução Sandinista foi abordada na seção Temas y paradigmas e nesse capítulo aparece na seção Los hechos. Não há grandes diferenças de abordagem, o que revela como as seções inicialmente pensadas pelos autores nem sempre alcançaram êxito na sua execução. A maior diferença que se nota é que no capítulo anterior, o objetivo dos autores foi mostrar o caso nicaragüense como um exemplo bem sucedido de revolução popular frente à dominação norte-americana, que naquele país tinha na família Somoza um grande aliado. Os sandinistas mantiveram-se no poder até o governo de Reagan, quando a reação conservadora aumentou, desgastando o governo, o que acabou resultando na eleição de Violeta Chamorro. Já no capítulo 15, o que se destaca é a existência de dois projetos políticos diferentes quando da luta para depor Somoza. Se num primeiro momento foi o grupo revolucionário que venceu, num segundo, quando se realizam eleições, foi outro, de centro direita, que assume o poder.

328 A região de Chiapas é uma das mais pobres do país, sendo palco de movimentos sociais camponeses importantes, que inspiram movimentos em outras regiões mexicanas ou mesmo na América Latina. 
exclusivos para se abordar a história latino-americana. Os autores destinam sempre o último capítulo de cada seção (unidade), em que se privilegia uma questão significativa para toda a região, mas que seja especialmente relevante para a compreensão da história argentina. Por exemplo: quando tratou do apogeu do mundo burguês entre 1850 e 1914 (capítulo 12), destacou-se para o estudo a consolidação dos Estados Nacionais, em particular a Argentina - quando se instaurou uma ordem política conservadora e se consolidou o modelo econômico agro-exporatdor. De igual modo, na seção que abarca os anos 1945 - 1973 (capítulo 21), tratase do peronismo e do anti-peronismo. Nele se insere um tópico com o título: Entre la Cepal y el FMI, abordando uma questão cara aos argentinos. Como os autores preferem destacar alguns problemas que consideram centrais, a tratar de um vasto repertório de informações, o resultado é uma abordagem bastante distinta do que vemos no outro livro argentino, elaborado pela equipe de Marisa Alonso. Pode-se dizer que os autores desenvolvem uma proposta de "História Integrada" com uma certa abordagem temática, sem abandonar, contudo, um eixo cronológico. Se é verdade que o repertório de informações apresentado aos alunos é menor, pó outro lado o texto favorece uma melhor contextualização da história Argentina, ainda que em detrimento de uma visão mais ampla da América Latina.

\section{A ICONOGRAFIA}

Retomemos, mais uma vez, à iconografia das obras. Que imagens da América Latina encontramos nos seis livros pesquisados?

Comecemos pelo primeiro tema comum a todos eles: a emancipação política das colônias espanholas. Como seria previsível, Bolívar é o personagem que mais aparece ${ }^{329}$ : em quatro dos seis livros vemos pinturas em que ele é retratado, e em outro um monumento representando-o. As legendas, porém, são bem diferentes.

No livro de Vicentino e Dorigo lemos: "Simón Bolívar recebeu o título de o 'Libertador' nas lutas de independência latino-americanas. Em diversas oportunidades expressava o ideal de uma América espanhola independente e

329 É digno de nota o fato de que no livro de Luciano de Privitellio e equipe não só não há um retrato de Bolívar, como seu nome não é mencionado em todo o capítulo, o mesmo ocorrendo com San Martín. É apenas na seção das atividades é que os alunos são instados a pesquisar quais eram os planos e estratégias desses dois líderes. 
unida, dizendo: 'Ciertamente la unión es la que nos hace falta para completar la obra de nuestra redención" "330. Nos créditos da imagem ficamos sabendo que se trata de um detalhe de um quadro a óleo de um certo Wolterbeck.

Lemos no livro de Pérez, Lara e Romero: "Junto com José de San Martín, Simón Bolívar logró la independencia de la mayor parte de los países de América del Sur. Não se menciona o artista que executou a pintura, apenas informa-se que ela se encontra no Museu Nacional de Lima, no Peru ${ }^{331}$.

Também é um detalhe de retrato que vemos no livro da equipe de Marisa Alonso. Bolívar, assim como nos dois outros casos, aparece com traje militar de gala. A legenda apenas informa "Simón Bolívar, el libertador de la Gran Colombia"332.

No livro de Marialba Pastor reservou-se um boxe para esse líder latinoamericano. A imagem reproduzida é uma foto de um monumento (em local não identificado), em que uma escultura de Bolívar, montado a cavalo, mostra-o tirando o chapéu, em sinal de reverência ${ }^{333}$. O texto explica os ideais de unidade política que mobilizaram Bolívar a lutar pela independência e soberania dos povos latino-americanos. Ao final se reproduz uma frase que teria sido dita em 1822: "El gran dia de América no há llegado. Hemos expulsado a nuestros opresores, roto las tablas de sus leyes tiránicas y fundado instituciones legítimas, mas todavía nos falta poner el fundamento del pacto social, que debe formar de este mundo una nación de repúblicas"334.

No livro de Pérez, Lara e Romero vemos só mais uma imagem sobre o tema, essa reproduzindo um quadro representando Toussain Louverture, igualmente em traje de general, montado em seu cavalo. Nos demais livros a iconografia é mais farta.

\footnotetext{
330 Vicentino e Dorigo, Op. cit. p. 326.

331 Pérez, Lara e Romero, Op. cit. p. 126.

332 Alonso, Marisa et al. Op. cit. p 33. Trata-se de um retrato pintado por artista anônimo, de 1829.

333 Trata-se de uma escultura de Adamo Tadolini, datado de 1859 e que se encontra em Lima, no Peru.

334 Pastor, Marialba. Op. cit. p. 74.
} 
No de Marialba Pastor o capítulo é aberto com o clássico mural sobre o grito de Dolores, pintado por O’Gorman, mas cuja legenda, como sempre, nada informa $^{335}$. Outras sete imagens são reproduzidas, em tamanho bem menor. Há duas imagens brasileiras, mas que não são devidamente identificadas: uma igreja setecentista mineira e uma gravura de Carlo Julião, representando dois escravos, mas cuja legenda erroneamente diz tratar-se de "negros em las Antillas" ${ }^{336}$. Nessa mesma obra vemos um detalhe de um quadro que é reproduzido integralmente no livro do grupo de Luciano de Privitellio, onde é corretamente identificada. A legenda que acompanha o quadro diz: "Combate de caballería em la época de Rosas', óleo de Carlos Morel, 1840. La pintura intenta reflejar la violência y la crueldade desatadas durante las luchas entre unitários y federales"337. Nesse mesmo livro vemos ainda outras duas imagens reproduzindo pinturas históricas. Uma é o quadro de Carlos E. Pellegrini, de 1830, denominado "El saladero". O outro, que abre o capítulo e por isso é reproduzido em tamanho grande, é uma aquarela de E.E. Vidal, de 1816, chamado de "Fuerte de Buenos Aires". Sobre a pintura, se reproduz uma fac-símile da Ata de Independência das Províncias Unidas do Rio da Prata.

Predominam, pois, imagens que mostram momentos fundacionais das nações latino-americanas, geralmente associados aos heróis nacionais ${ }^{338}$ e às grandes batalhas. De onde podemos concluir que, no tocante a esse tema especificamente, a iconografia mantém um padrão tradicional aos livros didáticos desde o século $X I X^{339}$.

Nos demais capítulos, encontramos várias fotos representando líderes políticos regionais, com destaque para Fidel Castro e Che Guevara, bem como para Salvador Allende e Augusto Pinochet. Predominam as fotos jornalísticas, que aparecem como registros dos acontecimentos de que se fala. No livro brasileiro de Myriam e Patrícia nota-se a preocupação de variar o tipo de suporte das imagens (gravuras, cartazes, charges), mas é no livro do grupo de Luciano de

${ }^{335}$ O mural encontra-se no Palácio de Chapultepec, na cidade do México. Na reprodução, destaque para a figura de Pe. Hidalgo.

336 Pastor, Marialba. Op. cit. pp. 70 e 72.

337 Privitellio, L et. al. Op. cit. P. 81.

${ }^{338}$ No livro de Marisa Alonso e equipe encontramos reproduzido o detalhe de uma tela representando D. Pedro I e o grito do Ipiranga.

339 Registre-se que em todos os livros vemos mapas que demonstram a nova divisão política da região. 
Privitellio que se encontra a maior variedade iconográfica. Há pinturas (não de caráter histórico),charges, cartazes, propagandas e fotos. Essas tanto podem mostrar um personagem ilustre, como mostrar um carro dos anos 1930 ou uma farmácia em que seu proprietário afixou cartazes pacifistas durante a II Guerra. Daí resulta um conjunto de referências visuais bem mais diversificado e rico do ponto de vista tanto histórico (enquanto fontes), como pedagógico.

\section{VISÕES DA AMÉRICA}

Dispomos de elementos para afirmar que há uma expressiva diferença entre os livros brasileiros e mexicanos frente aos argentinos, ainda que os dois daquele país também apresentem distinções relevantes. O primeiro aspecto a se destacar é que os livros brasileiros e mexicanos apresentam a América Latina como uma das regiões em que a expansão imperialista foi marcante. E para denotar uma postura crítica frente ao que ocorreu, os latino-americanos são vitimizados, ressalvando-se (mas sem muitos esclarecimentos) uma pequena elite beneficiária da aliança com o grande capital internacional. Se por um lado se busca apresentar um quadro geral de toda a região, por outro as generalizações, especialmente ao explicar o processo político (caudilhismos, regimes oligárquicos e ditaduras) transmitem uma visão segundo a qual os povos latino-americanos não foram sujeitos (ativos) de sua própria história, mas apenas coadjuvantes de uma trama que lhes era exterior.

Os dois livros argentinos procuram claramente superar essa visão. Às questões políticas se somam uma série de aspectos sociais e culturais, que mostram a singularidade dos processos de modernização latino-americanos. As inovações como o rádio, o cinema e a crescente vida urbana, não foi exclusividade dos países europeus e dos Estados Unidos. A vida cultural se transformou. A iconografia ajuda a demonstrar isso, apresentando mais do que fotos de episódios marcantes em vários países.

Quando analisamos os exercícios propostos relacionados a esses conteúdos, esses traços ficam ainda mais realçados. Trataremos mais especificamente das atividades no próximo capítulo, mas alguns aspectos devem ser aqui observados. O primeiro é que nos livros de Luciano de Privitellio, de Marialba Pastor e no de Pérez, Lara e Romero, há uma pequena quantidade de 
exercícios relacionados aos conteúdos de América Latina. Como tais conteúdos são apresentados em capítulos que contemplam vários outros temas, no momento de se elaborar as atividades eles não foram privilegiados.

O segundo ponto é que, mesmo quando encontramos exercícios correspondentes aos temas latino-americanos abordados, muitas vezes eles não dão margem a uma reflexão mais profunda por parte dos alunos. Um bom exemplo encontramos no livro de Myriam e Patrícia. No capítulo sobre a independência das colônias espanholas na América elas propõem as seguintes perguntas:

1. Explique por que os processos de independência dos países da América espanhola não proporcionaram benefícios às populações indígenas e nem às classes menos favorecidas.

2. Quais foram os fatores que contribuíram para os colonos espanhóis se mobilizarem e partirem para a conquista de independência?

3. O asiento e o permiso foram fatores importantes para a conquista da independência pelas colônias espanholas? Explique.

4. Por que o movimento que levou à independência do México foi essencialmente diferente dos outros países?

5. Pode-se comparar a monarquia mexicana com a brasileira? Por quê? ${ }^{340}$

Essa quarta pergunta pode dar a pensar que os alunos terão condições de dissertar sobre o processo de emancipação mexicano, comparando-o como os demais, especialmente com o caso brasileiro, na pergunta seguinte Mas é ilusória a impressão, pois o texto encontrado no livro não fornece subsídios para que se efetive uma comparação. Caberá aos alunos, quando muito, reproduzir o que foi dito pelas autoras no parágrafo destinado ao assunto.

Um outro aspecto que chama atenção é como os exercícios propostos reforçam as concepções de subordinação dos povos latino-americanos às potências capitalistas, visando assegurar que os alunos se apropriem dessas idéias. Myriam e Patrícia, ao afinal do capítulo 44, perguntam: 
1. Explique de que maneira a Inglaterra exerceu seu domínio imperialista sobre os países latino-americanos desde que estes se tornaram independentes, a partir do século XIX.

2. Qual era 0 interesse dos ingleses em patrocinar os movimentos antiescravagistas na América Latina? E como ficou a situação dos negros após a abolição, sobretudo no que se refere à sua inserção social e na questão da cidadania?

3. Quais foram os fatores que levaram à ascensão dos Estados Unidos (em detrimento da Inglaterra) à posição de "país dominante" sobre o restante da América Latina?

4. Por que o autoritarismo foi onipresente nos governos latino-americanos desde que estes se tornaram independentes?

5. Como estava a situação do México no período que antecedeu à Revolução de 1910? Apresente os principais motivos que levaram à deflagração do conflito ${ }^{341}$.

Curiosamente, no capítulo em que estas mesmas autoras tratam das experiências socialistas de Cuba, Nicarágua e Chile, as proposições mudam bastante de configuração:

1. Faça uma pesquisa a respeito da situação socioeconômica de Cuba à época da revolução e sobre o panorama político da ilha nos dias de hoje e responda: quais sãos os pontos positivos e os pontos negativos do regime socialista implantado naquele país?

2. Quais foram os fatores que precipitaram a derrocada financeira de Cuba a partir da década de $1990 ?$

3. Pesquise e responda: o que levou a justiça inglesa a considerar como legítimo o pedido de prisão do general Augusto Pinochet, expedido pelo juiz espanhol Baltazar Garzón?

4. Por que os Estados Unidos intervieram na Nicarágua durante a ditadura do ditador Zelaya?

5. Com base nas informações do texto e de outras pesquisas complementares, faça uma avaliação sucinta do atual quadro social, econômico e político da Nicarágua ${ }^{342}$. 
Observe-se que dos cinco enunciados, três sugerem pesquisas, o que levaria não só os alunos a buscar novas informações além daquelas contidas no livro, como a fornecer respostas muito mais abertas. Não é por acaso que ocorre isso, uma vez que está implícita na proposição desse capítulo a exposição de processos em que o protagonismo histórico coube aos latino-americanos, resistindo e combatendo a exploração de que eram vítimas.

Essa questão das atividades será aprofundada no capítulo que se segue, no qual procuraremos demonstrar melhor como se entrelaçam as concepções de história e de ensino nos livros didáticos. Mas antes de avançarmos em direção a ele, é interessante sublinhar que o debate sobre a importância de se ampliar os temas de história latino-americana nos currículos dos países da região é muito mais espinhoso do que pode parecer. Os livros brasileiros demonstram como apenas incluí-los nos programas escolares não resolve o problema do desconhecimento dessa história por parte das novas gerações. Afinal, veicula-se na literatura didática ainda hoje concepções que não dão conta de explicar a complexa realidade dos países dessa região. Nem mesmo quando fazem uso de uma bibliografia mais renovada, os livros conseguem romper com uma série de estereótipos estabelecidos por uma certa historiografia, e arraigados no senso comum.

Por outro lado, os livros argentinos, cada um ao seu modo, comprovam que é possível pensar saídas para essa questão. Possivelmente o fato de ambas romperem com a visão restrita dos planos econômico e político, procurando contemplar questões do âmbito cultural, tenha viabilizado uma abordagem mais ampla da história latino-americana. A periodização que estrutura as duas obras, ao reservar mais espaço para a história do século XIX e início do século $X X$, também contribuiu para que se delineasse melhor o quadro político de alguns países da região. 


\section{Capítulo VI}

\section{HISTÓRIA CONCEBIDA E HISTÓRIA ENSINADA}

No solo cambia cullturalmente lo que se aprende [...] sino también la forma en que se aprende. Como sucede en tantos órdenes de la vida ( el arte, el ajedrez, el fútebol o

la política entre otros), forma y contenido son en el aprendizaje dos espejos uno frente al otro, que para no provocar perplexidad o desasosiego en el observador deben reflejar las dos caras de una misma imagen. Si lo que ha de aprenderse evoluciona, y nadie duda que evoluciona y cada vez a más velocidade, la forma en que ha de aprenderse y enseñarse también deberia evolucionar, y esto quizá no suele asumirse con la misma facilidad, con lo que el espejo refleja una imagen estraña, fantasmal, un tanto deteriorada, del aprendizaje.

Juan Ignacio Pozo

Nesse último capítulo, procuro estabelecer com maior clareza e profundidade os vínculos existentes entre as concepções de história e as concepções de aprendizagem que sustentam necessariamente os livros didáticos. Analiso agora de modo mais sistemático as atividades propostas nas seis obras selecionadas. Objetivo com isso, também, aferir em que medida tais obras atendem às propostas curriculares apresentadas no capítulo 2, identificando o grau de congruência entre a história prescrita nas propostas curriculares em vigor e a história (possivelmente) ensinada em algumas salas de aulas mexicanas, argentinas e brasileiras.

\section{AS ATIVIDADES}

Seguramente, todo professor, para selecionar um livro didático, avalia não só seus textos - clareza na exposição das idéias, congruência com suas concepções, extensão dos capítulos, entre outros aspectos - como também as atividades sugeridas. Em tempos, como os nossos, em que os alunos têm cada 
vez menos paciência para assistir as exposições do professor, os exercícios jogam papel decisivo no dia-a-dia da sala de aula. Por essa razão, a elaboração das atividades é uma das partes que merece especial atenção dos autores e editores, que não raro delegam a assistentes ou consultores o desenvolvimento dessa parte do trabalho.

Em todos os livros que investigamos, encontramos pelo menos uma seção destinada a apresentar proposições de exercícios para os alunos. Em nenhum deles vemos apenas perguntas que visam a mera verificação de leitura (os chamados exercícios de fixação).

\subsection{A valorização das questões de aprendizagem}

Nos últimos anos, o deslocamento do foco no ensino de história do âmbito da informação para o da aprendizagem foi motivado em boa medida pela crescente difusão e valorização das questões pedagógicas, especialmente daquelas associadas ao desenvolvimento cognitivo dos alunos, segundo as quais o aprender a aprender, conferindo aos alunos um papel ativo, deveria ser o centro do trabalho escolar. Portanto, mais do que memorizar dados, os alunos devem aprender a usar essas informações para resolver problemas, responder indagações, construir novos conhecimentos. $\mathrm{E}$ isso se faz por meio de atividades diversas.

André Chervel considera que é tarefa dos historiadores das disciplinas "descrever a evolução da didática, pesquisar as razões da mudança, revelar a coerência interna dos diferentes procedimentos aos quais se apela, e estabelecer a ligação entre o ensino dispensado e as finalidades que presidem seu exercício"343. Marilu de Freitas Faricelli, seguindo essas orientações, em pesquisa recente procurou explicar as mudanças verificadas nas proposições dos exercícios e atividades em livros didáticos brasileiros para o Ensino Fundamental (terceiro e quarto ciclos) nos últimos anos. Ela observa que as preocupações no tocante à aprendizagem por parte dos autores e dos editores se alargaram expressivamente, demonstrando como elas decorreram de mudanças na forma

343 Chervel, André. "História das disciplinas escolares: reflexões sobre um campo de pesquisa". Apud Faricelli, Marilu de Freitas. Conteúdo pedagógico da História como disciplina escolar: exercícios propostos por livros didáticos de $5^{a}$ a $8^{a}$ série. Pontifícia Universidade Católica de São Paulo, 2005. Dissertação de mestrado. 
como se concebia a disciplina e, por conseguinte, o seu ensino. Tais mudanças, por sua vez, foram motivadas por uma série de embates travados em vários âmbitos sociais, entre as décadas de 1970 e 1990, em que diversos atores procuravam interferir na configuração da disciplina e do papel da escola ${ }^{344}$. Esse exemplo demonstra, mais uma vez, como são extremamente intrincados os fatores que interferem na configuração das disciplinas escolares, exigindo dos pesquisadores uma perspectiva de análise muito aberta, que dê conta de abranger o maior número deles.

A questão do desenvolvimento das habilidades operatórias, entendidas como conjunto de operações mentais que promovem o desenvolvimento cognitivo, ampliando essa própria capacidade, tem recebido especial atenção dos educadores $^{345}$. No caso específico de nossa disciplina, procura-se com isso superar a associação entre ensino de história e memorização, tão antiga e tradicional quanto o seu combate. Nem por isso, entretanto, os textos dissertativos/expositivos deixaram de desempenhar o mesmo papel importante do passado, às vezes ocupando espaço tão central quanto o das aulas - razão pela qual a figura do professor continua jogando papel decisivo, ainda que não seja mais, como aponta Faricelli, o "orador magistral" - cobrando dos próprios alunos, por vezes, a produção de textos, tanto orais como escritos. Portanto, a linguagem assume um papel central no ensino de História, independentemente dos objetivos que se estabeleçam para ele. Não por outro motivo, os professores tendem a colocar esse aspecto como um dos primordiais quando escolhem um livro didático para seus alunos.

344 Faricelli, Marilu de Freitas. Op. cit. p. 136-137.

345 Essa concepção educacional é tributária de vários psicólogos da educação, especialmente norte-americanos, como Benjamin Bloom, Louis Raths, J. Brunner, que estiveram muito em voga entre os anos 1940 e 1960. Seus estudos vieram na esteira das mudanças verificadas no campo da psicologia anos 1930, quando a corrente behaviorista deslocou foco das pesquisas da inteligência para a aprendizagem (entendida como comportamento observável). Jean Piaget, toma a questão das habilidades operatórias por um outro prisma, enfatizando a questão da aprendizagem dos conceitos dentro do processo cognitivo, formulando a sua teoria do desenvolvimento. Pode-se dizer que a aprendizagem por competências, da qual falamos no capítulo 2, é em certa medida um desdobramento dessas duas concepções, na medida que retoma a questão das habilidades operatórias e encontra em Piaget um referencial teórico central. Vygostsky foi outro estudioso que trouxe grande contribuição ao demonstrar como as interações sociais e os fatores culturais são fundamentais nesse processo do desenvolvimento cognitivo. Ver, entre outros, Fontana, David. Psicologia para professores. São Paulo: Edições Loyola, 1998; Moreira, Marco et. al. Aprendizagem: perspectivas teóricas. Porto Alegre: PADES/UFRG, 1987; Ronca, Paulo Afonso C. e Terzi, Cleide do A .O pensamento parece uma coisa à toa... Caminhos que ligam o pensar ao conhecimento. São Paulo: EDESPLAN, 2001. 
Freqüentemente, ao se desenvolver uma obra, a linguagem é preocupação de vários membros da equipe editorial, sendo comum a intervenção de editores de texto ou de profissionais especializados em copidesque, cuja principal atribuição é fazer com que a informação (conteúdo) seja passada da forma mais clara possível. Disso decorre, por exemplo, o fato de muitos livros terem parágrafos curtos e frases com períodos não muito longos, evitando-se ao máximo orações subordinadas, de modo que, durante a leitura, o aluno não perca a linha argumentativa. Os conectivos também são recursos muito usados, pois eles facilitam a interligação de uma idéia à outra. Também são bastante importantes as atribuições dos pesos aos títulos e subtítulos, o que, visualmente, se percebe no tamanho do corpo das letras, aplicação de cores ou outros recursos visuais, além dos recursos do italic e do negrito ${ }^{346}$. Assim, um texto em que o leitor percebe claramente a subordinação das idéias tende a ser mais facilmente compreendido $^{347}$. Esse trabalho na maior parte das vezes é atribuição da equipe editorial, cujo grau de intervenção depende, de um lado, da qualidade dos originais e, de outro, do quanto o autor autoriza que seu texto seja modificado. No caso de obras coletivas - caso dos dois livros argentinos que analisamos, por exemplo - , sobretudo quando os projetos editoriais são da própria editora, essas intervenções tendem a ser maiores, uma vez que será essa equipe que garantirá a padronização e mesmo a homogeneização dos textos, extirpando vícios de linguagem ou outras idiossincrasias de cada autor. Além disso, será essa equipe incluindo agora diagramadores e chefes de arte - que vai delimitar a extensão de cada tópico, de modo a se respeitar o projeto gráfico e a própria proposta editorial $^{348}$. Falamos, portanto, da estreita relação entre forma e conteúdo, com implicações diretas na compreensão do que se lê.

${ }^{346}$ Em cinco das seis obras analisadas encontramos o uso do chamado "destaque didático", ou seja, o uso do italic ou do negrito de modo a ajudar o leitor a realçar o que se considera mais relevante em um texto. Alguns autores usam com parcimônia esse recurso, enquanto outros usam freqüentemente, tanto para destacar conceitos, como termos e nomes. No livro de Luciano Privitellio e equipe o negrito é usado para destacar frases com idéias importantes. Isabel Solé observa que embora os leitores possam descobrir sozinhos as finalidades desses recursos gráficos, seria muito melhor que os professores ensinassem aos seus alunos como fazer uso deles para ampliar sua compreensão leitora, coisa que raramente se vê nas salas de aula. Sole, Isabel. Estratégias de leitura. Porto Alegre: ArtMed, 1998.

348

Um bom exemplo disso ocorre quando o projeto gráfico define que não haverá quebra do texto de uma página para outra ou que cada página começará com um subtítulo em peso 1 ou 2, como é o caso do livro da Puerto de Palos. 


\section{CONCEPÇÕES DE ENSINO}

Apesar das mudanças na forma de se conceber o ensino, há quem continue colocando na informação o foco do ensino de História, considerando essencial que seus alunos saibam certo repertório de conteúdos, tomado como social e culturalmente relevante. Assim, por exemplo, um aluno deve saber quem foi Ramsés II, César, Napoleão e Getúlio Vargas; deve conhecer os diversos "ciclos econômicos" do Brasil, desde o período colonial; não se admite que ele termine sua escolaridade básica sem saber a importância da Batalha de Waterloo e de Stalingrado e sem reconhecer o "legado cultural" dos gregos, dos romanos e dos renascentistas; é imprescindível ainda que identifique os grandes acontecimentos do século XX. Esses conhecimentos são considerados importantes em si mesmos, ou pelo que representam na história da humanidade ou para a história da civilização, na qual a história do Brasil se insere. Esse repertório faz parte de uma cultura geral que as novas gerações precisam conhecer.

Os dois livros mexicanos, dentre os seis analisados, são os que melhor exemplificam essa concepção informativa do ensino de História. Marialba Pastor, a autora mexicana, ao longo da obra, formula enunciados que revelam claramente esse propósito, como podemos ver nos exemplos a seguir:

Localiza las biografias de Federico II el Grande de Prusia, la emperatriz María Teres de Austria, Carlos III de Espanha y Catalina II la Grande de Rusia. Destaca las actividades realizadas por ellos para modernizar sus naciones. Expresa si es correcto llamarlos "déspotas ilustrados" y por qué.

Elabora una breve biografia de Garibaldi.

¿Quién fue Heinrich Himmler? ¿Qué fue la Gestapo y qué funciones realizó durante la Segunda Guerra Mundial? ${ }^{349}$

De modo semelhante, são recorrentes os enunciados no livro de Pérez, Lara e Romero que começam com expressões do tipo "o que foi...", "quem foi...", "quais foram...", típicos de questões de verificação de leitura . No livro da equipe de Marisa Alonso também encontramos inúmeras perguntas com esse mesmo tipo de enunciado, com o propósito de que os alunos recolham do texto as idéias mais 
importantes. Porém, esses questionários cumprem uma finalidade pedagógica de preparar os alunos para uma segunda ordem de questões, mais reflexivas, que serão propostas nos boxes Batir y debatir ideas, apresentados ao final da seção temas y paradigmas.

É grande o número de professores que consideram que o domínio dos conceitos é mais importante do que o domínio das informações, pois são a partir deles que se constrói efetivamente o conhecimento histórico. As aulas, por essa razão, devem privilegiar a compreensão ou a construção de um repertório de conceitos básicos, como monarquia, república, absolutismo, iluminismo, despotismo esclarecido, mercantilismo, liberalismo, etc. Mais do que a definição, os alunos deverão demonstrar ter compreendido, por exemplo, que o conceito de monarquia é mais amplo (inclusivo) do que absolutismo, reconhecendo no segundo uma tipificação do primeiro; devem distinguir monarquia constitucional de república, reconhecer que metalismo é uma idéia subordinada ao mercantilismo. Nessa abordagem, os textos tendem a ser mais densos do que propriamente longos e factuais, podendo mesmo atingir elevado grau de abstração, o que motiva os alunos freqüentemente considerar, e com razão, a matéria bastante difícil. Alguns professores chegam mesmo a esperar que no final do Ensino Médio um aluno consiga fazer pequenos mapas conceituais sobre um determinado tema ou desenvolver pequenas dissertações em torno dos mesmos.

Pérez, Lara e Romero demonstram em muitos momentos preocuparem-se com o domínio dos conceitos:

¿Que se entendia por conservadurismo político durante la primera mitad del siglo XIX? ¿cuáles eran sus principales postulados?

¿Qué características tuvo el nacionalismo del siglo XIX?

¿Qué es el Estado benefactor? ${ }^{350}$

Myriam e Patrícia também mostram esse cuidado, como no seguinte caso:

Determine a importância dos conceitos de virtù e fortuna para o pensamento político da modernidade e na contemporaneidade ${ }^{351}$. 
A aprendizagem com ênfase nos conceitos exige vários cuidados. Maria

Auxiliadora Schmidt e Marlene Cainelli, por exemplo, advertem que

Aprender conceitos históricos é constituir uma grade de referência que auxilie o aluno em sua interpretação e compreensão da realidade social, facilitando a leitura do mundo em que vive. Ensinar conceitos históricos não e impor o uso abusivo de termos técnicos e definições abstratas nem memorização de palavras e de seu significado. ${ }^{352}$

Para tanto, é desejável que se conheçam os processos mentais envolvidos na construção dos conceitos (entendida como elaboração e reelaboração dos mesmos), recorrendo-se à psicologia cognitiva, que tem procurado esclarecer esses processos. ${ }^{353}$ Nesse sentido, as aulas, sobretudo o trabalho do professor

352 Schmidt, Maria Auxiliadora e Cainelli, Marlene. Ensinar história. São Paulo: Scipione, 2004, p. 63.

353 A respeito das diferentes abordagens no campo da Psicologia das teorias dos conceitos, ver Lomônaco, Luis Fernando. A natureza dos conceitos: visões psicológicas. Instituto de Psicologia da Universidade de São Paulo, 1997. Tese de livre docência. Considero as contribuições da chamada visão teórica muito promissoras para se pensar a formação dos conceitos no ensino de história, embora não conheça iniciativas nesse sentido. Isabel Barca, Mario Carretero e outros pesquisadores têm se dedicado à questão da aprendizagem dos conceitos históricos a partir de uma perspectiva cognitivista, ainda que apontem para direções muito distintas. Considero, porém, que a metodologia de pesquisa própria da área da Psicologia, focada em experimentos com pequenos grupos, ainda não conseguiu formular um conjunto de orientações metodológicas mais amplas, que possam ser aplicadas pelos professores, pouco favorecendo o repensar da prática visando a construção dos conceitos. Penso também que a preocupação centrada na noção de causalidade histórica em boa parte desses estudos, ainda que importante, diz respeito a um aspecto muito limitado na construção do sentido da experiência histórica. Não conheço trabalhos de historiadores ou professores de história que, partindo dos aportes teóricos da Psicologia, pensem a especificidade dos conceitos históricos, uma vez que eles adquirem sentidos variados dependendo da realidade histórica estudada, o que é um complicador a mais para o estudante. Assim, apesar de envolver uma generalização atemporal, o conceito de escravidão possui atributos particulares quando empregado com relação à Grécia Antiga ou ao Brasil colonial. Há por outro lado diversos pesquisadores fortemente empenhados em compreender como os alunos constroem as noções de temporalidade histórica, como são os casos da Profa Lana Siman, na Universidade Federal de Minas Gerais, e de Sandra Regina Ferreira de Oliveira. Exemplos desse esforço vemos nos dois artigos que ambas publicaram em De Rossi, Vera Lucia S. e Zamboni, Ernesta (Org.). Quanto tempo o tempo tem. Campinas, Alínea, 2003.

Seguindo uma outra linha, de corte mais epistemológico, Nilson Machado fornece importantes considerações sobre a questão do conhecimento concebido como uma rede constituída por feixes de relações, em que os conceitos desempenham o papel importante, como conectores da rede, o que considero outra contribuição relevante para se enfrentar esse problema. Ver Machado, Nilson. Epistemologia e didática: as concepções de conhecimento e inteligência e prática didática. São Paulo: Cortez, 2000.

Holien Gonçalvez Bezerra no artigo Ensino de História: conteúdos e conceitos básicos sugere um núcleo básico de conceitos e categorias organizadores dos cursos de História, mas, ainda que mencione as habilidades e as competências, não os aborda desde uma perspectiva da aprendizagem. Já Janice Theodoro, em outro artigo do mesmo livro, intitulado Educação para um mundo em transformação aponta algumas habilidades consideradas básicas (identificar, comparar, relacionar), embora também não as aborde segundo uma perspectiva pedagógica ou psicopedagógica. Ver In: Karnal, Leandro (org.). História na sala de aula: conceitos, práticas e propostas. São Paulo: Contexto, 2003, p. 37 a 48 e 49 a 56 respectivamente. 
explorando as diversas dimensões dos conceitos, assumem grande importância, pois é pouco provável que apenas os textos consigam dar conta disso.

Aproveitando as considerações de Cainelli e Schimidt, é interessante observar que em quatro dos seis livros as atividades não são propostas apenas ao final do capítulo, ou seja, neles não há uma separação estanque entre o "momento de ler" e o "momento de exercitar", entendendo-se que 'e nessa interação que os alunos vão desenvolvendo seu pensamento.

Uma outra forma de abordar o ensino de história considera que mais do que informações ou mesmo conceitos, o aspecto primordial no ensino de história deve ser o encadeamento dos fatos, reconhecendo causas e conseqüências. Segundo essa perspectiva, os alunos devem ser capazes, por exemplo, de reconhecer ou identificar um conjunto de fatores que determinaram o fim do império romano, a eclosão da Revolução Francesa ou o golpe militar de 1964. Melhor ainda se forem capazes de enumerar as conseqüências desses mesmos episódios, reconhecendo nelas também a condição de causas de outros acontecimentos. Os alunos, assim, compreenderiam como se desenrola a história, numa sucessão encadeada de acontecimentos.

Os livros analisados nos fornecem exemplos desse tipo. Myriam e Patrícia solicitam do aluno que "Estabeleça a conexão entre Revolução Industrial e êxodo rural”354. Os mexicanos Pérez, Lara e Romero perguntam: ¿Quáles fueron las principales consecuencias de la Primera Guerra Mundial? ${ }^{355}$

Um pouco mais ambicioso é o ensino que, para além das causas e conseqüências, espera que os alunos compreendam como a história constitui um processo, marcado por transformações incessantes. Quanto maior for a sua capacidade de articular ou relacionar fatores ou componentes desse processo, estabelecendo uma rede de relações, maior terá sido sua compreensão histórica.

Esse é um dos objetivos de Vicentino e Dorigo quando apresentam, ao final de cada capítulo, um esquema-resumo, a partir do qual os alunos devem produzir um texto, como podemos ver no exemplo abaixo. Eles terão de elaborar uma 
versão pessoal que explique um certo assunto, que necessariamente articula informações, conceitos, causas e conseqüências. Não encontramos nada parecido nos dois livros mexicanos.

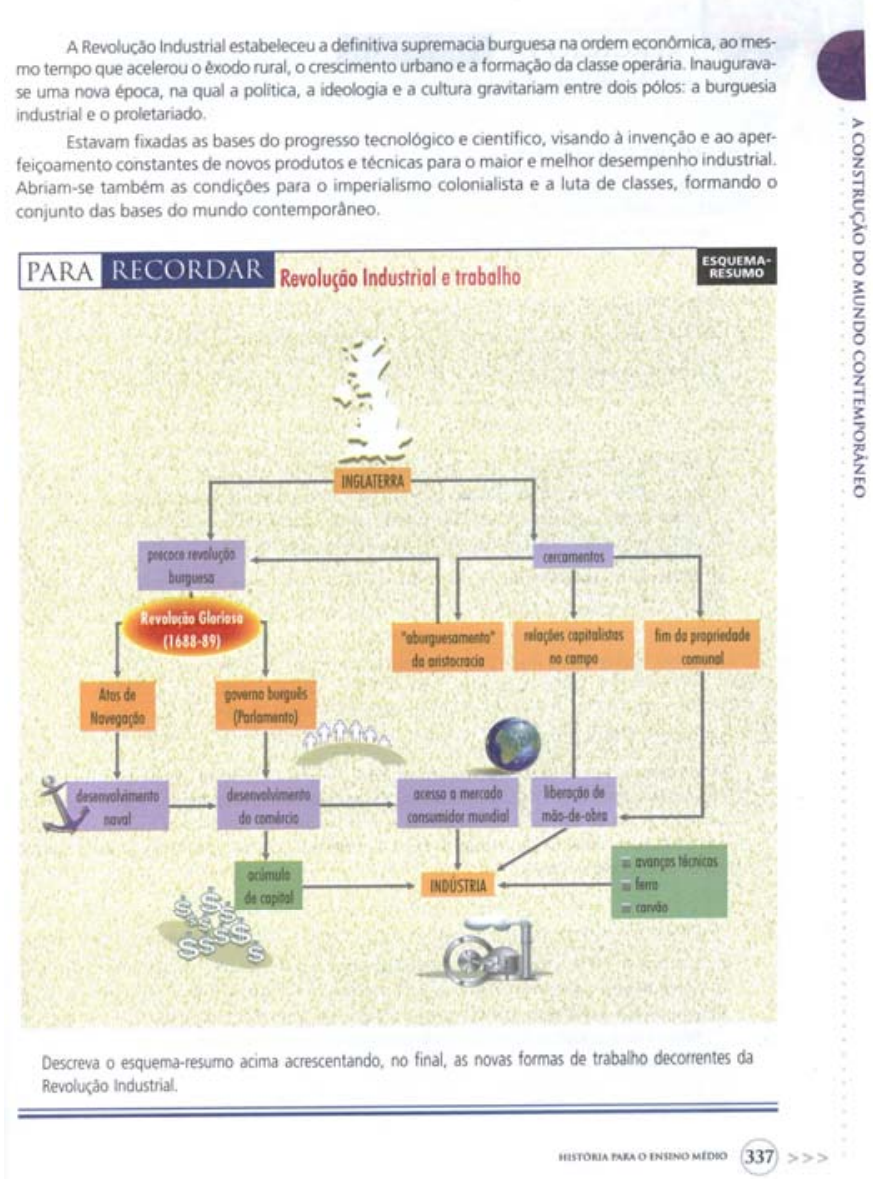

Pode-se somar às transformações sociais, econômicas ou culturais a preocupação de se mostrar as permanências que também marcam o processo histórico. Não são muitos os exemplos encontrados nos livros desse tipo de objetivo, mas podemos mencionar a atividade 1 do capítulo "Las vanguardias y la cultura de masas", do livro de Luciano de Privitellio e equipe.

Escriban un pequeño ensayo en el que se analice el papel de los medios de comunicaciones durante el periodo estudiado.

Comparen ese papel con el que juegan los medios en nuestra sociedad actual $^{356}$. 
É visível a diferença desse tipo de enunciado frente àqueles que visam apenas a informação. Além de produzir um pequeno texto, ele precisa comparar duas épocas, o que pressupõe identificar semelhanças e diferenças.

O ensino de História pode ter como objetivo principal desenvolver nos alunos a capacidade de reflexão, tendo sempre como ponto de partida situaçõesproblema do presente, que por sua vez remetem ao estudo do passado, fornecendo elementos que ampliem a compreensão desse presente. Ou, invertendo a ordem, depois de pensar uma questão enfrentada por uma sociedade do passado, puder refletir sobre o seu próprio tempo. É nesse confronto de temporalidades históricas que o aluno poderá compreender melhor a realidade em que vive.

Nos dois livros brasileiros, de modo especial no de Myriam e Patrícia, como já salientamos, essa preocupação é central. Em ambos são muitos os exemplos de proposições de questões em que a relação passado presente se dá por meio de um problema. Vicentino e Dorigo, por exemplo, tomam como referência duas diferentes visões sobre a Revolta da Vacina, de 1904, para propor:

Procure identificar um episódio recente em que uma manifestação popular foi interpretada de formas diferentes $[\ldots]^{357}$.

Muitas vezes esse tipo de proposição aparece associada ao um trabalho de análise de pequenos excertos, que podem ser tanto de documentos históricos como de textos historiográficos. Revela-se assim o intuito de fazer com os que os alunos percebam como é o trabalho de construção do conhecimento histórico, realizando pequenos ensaios de inquirir ou comparar fontes, confrontar interpretações sobre um mesmo fato.

Vicentino e Dorigo, nesse sentido, são bastante inovadores. Em sua obra não encontramos o tradicional questionário ao final de cada capítulo, por meio do qual os professores possam "checar" a leitura de seus alunos. Eles preferiram apresentar dois ou três exercícios de caráter mais analítico e reflexivo, demandando uma outra ordem de esforço cognitivo dos alunos. 
Mas as maiores inovações são aquelas vistas no livro argentino de Luciano de Privitellio e equipe, pois os autores conseguiram articular a metodologia do trabalho histórico com uma metodologia do ensino de História que considera os passos necessários para se chegar a um pensamento histórico mais autônomo por parte dos alunos. Efetivamente, o que encontramos são inúmeras situações do "aprender a aprender", de tal sorte que, em outras situações, os alunos possam fazer uso tanto de seus conhecimentos históricos como de uma série de procedimentos metodológicos que os habilitem a ampliar seus conhecimentos. Vejamos um exemplo. Ao final do primeiro capítulo, a seção Caja de herramientas (cujo nome já indica a sua finalidade), apresenta um texto que explica no que consiste a prática historiográfica. Entre outras coisas, destaca a importância que tem os textos para esse "que hacer" e conseqüentemente como é imprescindível realizar leituras cuidadosas dos mesmos. Seguem-se, então, dois trechos, um de Hobsbawm e outro de José Luis Romero, um historiador argentino. No primeiro o historiador inglês trabalha o que chama de "a dupla revolução", enquanto o segundo aborda a noção de "cultura ocidental". O boxe Practique propõe aos alunos:

- Lean ambos os textos: ¿ cuál es el tema que interesa a cada uno de los autores?

- A partir de la definición del tema, piensen un título para cada uno de los textos.

- Busquen en el diccionario el significado de las palavras que no conoscen.

- Vuelva a leer los textos. En cada uno señale con un color la idea o las ideas principales y con otro color, las secundarias.

- ¿Qué significa para Hobsbawm "doble revolución”? ¿Por qué esta expresión puede referirse simultaneamente a un acontecimiento localizadoy a la vez mundial?

- Qué es para Romero la "cultura occidental"?

- Escriban un breve texto explicando la idea general de cada uno de los autores. Esas ideas ¿les parecen coincidentes o antitéticas? Justifiquen la resposta. 
É notável o cuidado de se estabelecer um passo-a-passo, mesmo que se tratem de alunos como 14 ou mais anos, coisa que não se observa nos casos dos dois livros brasileiros. No capítulo sobre o lluminismo, por exemplo, Vtino e Dorigo selecionaram dois pequenos fragmentos de textos, um de John Locke e outro de Jean Jacques Rousseau, a partir dos quais se solicita que se compare os dois textos, destacando suas diferentes concepções de política e representatividade, tomando como referencial [o texto da seção] Para pensar historicamente ${ }^{358}$. A realização da proposição apresentada parece pouco viável por parte dos alunos, pois os comandos são muito gerais para desenvolvê-la.

No capítulo seguinte, os autores argentinos usam a mesma situação: um texto de orientação, denominado Inventando tradiciones, inventando historias, seguido de seis pequenos fragmentos de textos, agora tratando de cultura e pluralismo cultural. E de novo a proposta de uma atividade, passo a passo. Observe-se que as atividades nessa parte do capítulo são concebidas sempre como coletivas (ou feitas em grupos, ou com todo o grupo classe), o que torna as aulas mais dialogadas, participativas, conferindo ao professor muito mais o papel de mediador.

\section{INTRODUÇÃO AOS ESTUDOS E OS CONHECIMENTOS PRÉVIOS ${ }^{359}$}

Vejamos um outro aspecto associado à aprendizagem, agora ligado ao modo como os temas são introduzidos, o que nos remete ao tipo de conhecimento prévio dos alunos se procura mobilizar.

A seção Lo que tu ya sabes do livro de Marialba Pastor, como o nome faz supor, teria a finalidade de relembrar ao aluno algo que ele já viu em outro momento de sua escolaridade. Alguns boxes cumprem esse papel, como aquele em que trata dos tipos de produtos que mais atraíram os europeus ao Oriente,

358 Vicentino, C. e Dorigo, G. Op. cit. p. 264.

359 Chamamos aqui de conhecimentos prévios conhecimentos adquiridos pelos alunos por outros meios que não a escola ou aqueles nela apreendidos em séries anteriores. Não estamos considerando nesse caso a retomada de conteídos vistos em capítulo anterior do livro, situação que configuraria mais uma recapitulação ou revisão. Não encontramos por entre as centenas de exercícios propostos nos seis volumes nenhum que, por exemplo, contrapusesse conhecimento do censo comum com aquele produzido pelos historiadores. 
resultando daí a expansão marítima ${ }^{360}$. Ou aquele que informa que parte do continente americano ficou sob domínio francês e inglês ${ }^{361}$. Entretanto, há outros boxes que provavelmente introduzem novas informações e não exatamente as relembram, como por exemplo o que transcrevemos a seguir:

Todos los nacionalismos difunden un relato imaginario - que muchas veces contiene fundamentos históricos - sobre el grandioso origen de sus pueblos y la inigualable sabiduria y valor de sus heróes. A este relato se le conoce como mito de origen y tiene la función de unir la diversidad en torno a símbolos y sentimientos comunes ${ }^{362}$.

Vê-se uma explicação breve sobre uma idéia que não deve ser nada simples ou trivial para o aluno de 14 ou 15 anos. É razoável supor que para o aluno atribuir sentido a esse texto, será preciso que o professor se detenha por uns bons minutos sobre ele. Um outro exemplo da mesma situação vemos abaixo:

La Bauhaus fue una escuela de arquitetura fundada por el alemán Walter Gropius y luego cerrada por los nazis. Una de las divisas de este pensador fue: "lo útil es lo belo"363.

De modo semelhante, apesar da singeleza do lema de Gropius, ela possui um sentido filosófico (estético) que também não é simples ou trivial. Algo parecido ocorre com outro tipo de boxe, denominado de Para recordar. Percebe-se, assim, uma ambigüidade entre a finalidade prevista para os boxes e o papel que eles realmente desempenham, o que não ajuda o aluno.

Por outro lado, a autora introduz cada unidade com um boxe que diversas vezes contém uma ou mais perguntas que mobilizam conhecimentos prévios dos alunos. Por exemplo: na abertura da unidade 7, pergunta-se "¿Por qué estalló la Segunda Guerra Mundial? ¿Cuál fue la causa por la que nuevamente el mundo entró en un proceso masivo de destrucción? ${ }^{364}$ Nesse caso, de fato os alunos poderão recorrer ao que aprenderam em uma série anterior.

\footnotetext{
360 Pastor, M. Op. cit. p.23.

361 Idem, p. 27.

362 Idem p. 78.

363 Idem, p. 177.

364 Idem, p. 210.
} 
Tanto a equipe de Luciano de Privitellio como a de Marisa Alonso também procuram fazer uso dos conhecimentos que os alunos já dispõem, mas não encontramos nos livros brasileiros uma preocupação semelhante. Por outro lado, nota-se em todos os seis um cuidado em orientar o estudo da unidade ou capítulo, oferecendo indicações bastante explícitas das idéias centrais a serem retidas pelos alunos.

Marialba Pastor, por exemplo, apresenta com grande destaque visual ${ }^{365} \mathrm{o}$ que chama de conceptos claves, mas que seriam mais apropriadamente denominados de idéias chaves. Organizados em tópicos, lemos, por exemplo, na abertura da unidade 4, sobre o capitalismo e o imperialismo:

- En la época contemporánea, no es posible encontrar un momento en el cual el desarrollo industrial se haya detenido. Desde fines del siglo XVIII en ocasiones con mayor velocidad y en otras más lentamente - , la ciencia y la tecnologia han continuado sus avances y descobrimientos. A lo largo del siglo, la cresciente acumulación de capitales generó enormes inversiones en nuevas empresas de descubrimiento, exploración y explotación. Pero el interés de estas empresas no fue " el arte por el arte" o " la ciencia por la ciencia", sino los benefícios que se obtendrían con su promoción. El interés básico fue economico: investir para ganar más.

- Como sólo las potencias industriales contaron con recursos para emprender la nueva conquista del mundo, fueron ellas los motores de la gran transformación. El resto de las naciones quedaron confinadas al atraso o en condición de satélites de los grandes imperios.

- La era del llamado imperialismo comprende la segunda mitad del siglo XIX y, principalmente, el último tercio de ese siglo. Durante esos años, los proyectos de expansión del capitalismo se acompañaron de nuevas visiones del mundo. Los grandes imperios se convencieron de ser, cada uno de ellos, los elegidos para emprender la mision civilizadora de toda la humanidad $^{366}$. 
Por essa abertura já se identifica a concepção de história que preside essa obra, que toma como paradigma de desenvolvimento aquele que os países centrais forjaram, o que leva a taxar de atrasados e satélites os que estavam submetidos aos impérios coloniais. Mas o que queremos ressaltar aqui é o fato dessa seção pontuar as idéias centrais dos capítulos que se seguem, de modo que os alunos encontram bastante realçado o que devem guardar como essencial no texto. A seção Resumen de unidad comprovará isso, desenvolvendo um pouco mais cada um desses tópicos (no caso referido, em sete parágrafos).

O aluno encontra mais uma orientação de leitura no texto que se segue à imagem de abertura de capítulo, que também supostamente serve de introdução ao que será apresentado a seguir. Percebe-se, pois, uma deliberada atenção com as aberturas de unidades e capítulos, inclusive do ponto de vista visual, que desempenham importante papel pedagógico.

No outro livro mexicano, de Pérez, Lara e Romero, também encontramos o mesmo cuidado de, ao se iniciar um novo capítulo, elencar uma série de idéias, apresentadas em tópicos, que constituem os contenidos esenciales. Visualmente, eles são destacados por pequenos sinais (setinhas amarelas). E, do mesmo modo que no livro de Marialba, ao final do capítulo, há uma síntese, onde se desenvolve cada uma dessas idéias. Ressalte-se, pois, que em ambos os livros não são os alunos que precisam selecionar as idéias principais, pois os autores o fazem. Assim procedem talvez porque considerem que os alunos têm dificuldade em realizar essa tarefa - de fato, problema recorrentemente apontado pelos professores -, preferindo garanti-la ao apresentá-la pronta, fornecendo um guia mais seguro para os alunos estudarem. Resta perguntar, no entanto, quando eles adquirirão autonomia para desempenhar essa tarefa por conta própria, posto que sairão do Ensino Médio sem aprender a fazer isso sozinhos. Mas, creio, essa escolha pode ser resultado da própria concepção de conhecimento que está subjacente ao texto, porque ele também é dado como pronto e acabado, não havendo nenhuma situação de confrontação de visões ou interpretações sobre um dado assunto. Não há problemas ou questões no meio do texto, que levem o aluno a pensar sobre o que está aprendendo. Portanto, mais do que uma concepção de ensino, o que se explicita aqui é uma concepção sobre o próprio conhecimento, de total passividade por parte de quem aprende. 
O livro de Vicentino e Dorigo também possui duas seções com o objetivo de introduzir o estudo de um tema. O primeiro, mais longo, abre cada uma das cinco unidades e tem por nome Discutindo a História. Trata-se de uma seção de reflexão, quase sempre conceitual ou historiográfica, abrindo um leque de questões que devem orientar sobretudo o professor, a quem parece que a seção se destina especialmente, uma vez que o texto, mesmo mantendo sua preocupação didática, é visivelmente mais denso. Um bom exemplo encontramos na seção que abre a unidade 3 , sobre a Idade Moderna, em que os autores discutem se História do Brasil e História Geral seriam "duas histórias"367. Igualmente relevante e esclarecedora é a discussão que se segue, sobre o eurocentrismo e a periodização quadripartite (Antiguidade, Idade Média, Moderna e Contemporânea). O que os autores pretendem é chamar atenção para o que está por trás dessas duas abordagens e por trás desses recortes (Geral e do Brasil), que os autores, aliás, seguem. Nessas seções, os autores ousam avançar, indo além do que é comum encontrar nos livros da disciplina, inclusive procurando trazer para o âmbito da escola discussões mais restritas aos âmbitos acadêmicos, como é o caso das representações ${ }^{368}$, que ele abordam em vários capítulos.

Outro momento de "preparação" ou "aquecimento" é o boxe Para pensar historicamente, quando os autores formulam um problema de natureza histórica. Vejamos alguns exemplos:

\section{Economia e política}

O processo de expansão marítima européia é um marco no início da europeização do mundo. Ele foi feito a partir de claras demandas

367 Vicentino, C. e Dorigo. G. Op. cit. p.164.

368 No boxe Para pensar historicamente do capítulo 38 (referente à II Guerra Mundial), lemos o seguinte: "A questão das representações ganhou importância ente os historiadores nos últimos tempos, já que o registro da história decorre de interpretações da multiplicidade dos pontos de vista. A maneira como os homens representam a realidade em que vivem, ou como as realidades produzem tais representações, coloca o problema da verdade/objetividade na historiografia e na história.

Na Segunda Guerra Mundial, como em outros processos históricos que analisamos, é possível depararmos com representações distintas sobre os acontecimentos". Na seção dos exercícios, os autores apresentam considerações de Pierre Vilar sobre essa mesma questão, em que ele comenta como alunos parisienses associam Guernica hoje apenas ao célebre quadro de Picasso, dissociando-o completamente da Guerra Civil Espanhola. Essa situação, segundo os autores, exemplifica os casos recorrentes em que "as representações passam a ser mais importantes na imaginação das pessoas do que o próprio fato". Vicentino, C. e Dorigo, G. Op. cit. p.511e 523 . 
econômicas e viabilizado por poderosas forças políticas. O sucesso da expansão significou evidentes vantagens para certos personagens que a projetaram e executaram. Quem eram eles? Como se distribuíram os benefícios e os custos do empreendimento? ${ }^{369}$

Qual o papel do Brasil na América Latina?

O processo de independência na América espanhola foi diferente do ocorrido na América portuguesa? Refletir sobre as semelhanças e diferenças entre os processos significa um ponto de partida para a análise de inserção do Brasil no conjunto da América Latina. O que nos une aos demais países latino-americanos e o que nos separa deles?

A unidade latino-americana foi um sonho acalentado desde os tempos das independências. Qual a importância da união latino-americana tanto no passado como no presente ${ }^{370}$

O "outro" na expansão imperialista

A expansão imperialista do século XIX foi um novo passo no processo de mundiaização da ordem capitalista, depois das cruzadas, da expansão ultramarina, da colonização, etc. As populações africanas e asiáticas foram tragadas e incorporadas a uma ordem essencialmente européia.

Como foram vistas pelos europeus essas "novas" populações da Ásia e da África? Como o Ocidente absorveu o "outro"? Como os conquistados foram encarados pela Europa, eixo do desenvolvimento capitalista e suposto palco do desenvolvimento dos direitos humanos? ${ }^{371}$

Ao se confrontar essas proposições com os conteúdos tratados em cada capítulo, constata-se que em muitos casos a discussão anunciada é mais ampla do que aquela efetivamente trabalhada. Ao abordar a expansão colonial, a questão do "outro" é tratada de modo muito mais limitado do que se poderia supor pela introdução, especialmente porque, nas atividades, quando se coloca mais claramente a questão, ela é enfocada apenas a partir da perspectiva dos europeus, mesmo que de modo crítico. Por outro lado, essas indagações iniciais 
podem se converter em discussões em sala de aula, se assim os professores desejarem.

Algo semelhante também ocorre no livro das duas brasileiras, Myriam e Patrícia, como já tivemos oportunidade de observar. Nesse caso, entretanto, as ambições são ainda maiores, porque o texto de abertura dos capítulos sempre serve para que as autoras estabeleçam algum tipo de problematização entre o passado e o presente. Um bom exemplo encontramos no capítulo 3, denominado Quem somos?, em que se trata da identidade do homem americano. Para introduzir o estudo, as autoras trazem um texto de José Manuel Durão Barroso (datado de 1999, quando ele havia sido eleito presidente do Partido Social Democrata português), no qual ele tece considerações sobre a identidade européia em franco processo de integração, defendendo a intensificação das trocas culturais, de modo a se "abrir horizontes, abrir o espírito". As autoras, começam, então sua exposição assim:

Pelo texto anterior você pôde perceber que a questão da identidade de um povo tem sido preocupação de diversas sociedades. No caso da América Latina, essa preocupação data do século XIX. Em 1819, Simon Bolívar, herói da libertação latino-americana, afirmou: "Não somos europeus, não somos índios, mas sim uma espécie intermediária entre os aborígenes e os espanhóis [...]. Mantenhamos presente que o nosso povo não é nem europeu nem americano do norte, é antes uma composição de África e América do que uma emanação da Europa ... é impossível determinar com propriedade a que família humana pertencemos".

A questão estabelecida por Simón Bolívar continua a ter ressonância em diversos campos da ciência. É o que têm demonstrado pesquisas feitas por arqueólogos, paleontólogos, antropólogos, bioantropólogos, paleobiólogos, historiadores e outros, em toda a América Latina.

Como o homem chegou à América? Quais são os vestígios mais antigos da região? Estas são questões amplamente discutidas nos círculos científicos e importantes para a construção da identidade do homem latino-americano, uma vez que aos olhos dos norte-americanos e europeus não temos uma "face definida"372. 
Ressalte-se o caminho largo proposto pelas autoras: tomam inicialmente 0 texto de Barroso, no qual ele ressalta o grande poder de circulação da cultura e dos valores americanos, graças ao poder das mais variadas mídias de que aquele país dispõe, para se chegar à questão da identidade européia; lança-se então a questão da identidade latino-americana à época das independências, onde se entrecruzam aspectos políticos, econômicos e culturais, para finalmente se chagar onde se pretende: a origem dos primeiros homens americanos. É um leque muito amplo de questões - relevantes, sem dúvida - mas não parece que conhecer com mais precisão as origens dos primeiros grupos que ocuparam nosso continente há 50, 35 ou 20 mil anos seja um componente importante para se dar "uma face mais definida" aos latino-americanos de hoje. É muito engenhoso esse percurso, mas do ponto de vista pedagógico, será realmente eficiente misturar tamanha ordem de questões para se introduzir um conteúdo que ocupa exatas três páginas? A pergunta parece ainda mais pertinente quando constatamos que nas cinco atividades propostas a questão das identidades latino-americanas não é retomada. A estratégia usada para introduzir o capítulo parece mais um artifício do que propriamente uma problematização.

A equipe de Luciano de Privitellio também adota como regra a formulação de um texto introdutório para cada capítulo que se inicia, sempre acompanhado de uma ou mais imagens. O nome da seção explicita sua finalidade: Para entrar en el tema, e muitas vezes o texto procura estabelecer relação com as imagens e com conhecimentos prévios dos alunos. A oralidade é também estimulada, tanto em atividades em grupo como envolvendo toda a classe. Embora o professor possa não fazer uso desses recursos, é provável que o faça, na medida que eles são facilitadores de seu trabalho, pois economizam tempo tanto no planejamento da aula como no desenvolvimento dela. O professor pode estimar quanto tempo deverá dedicar a esse momento de aquecimento, mantendo o seu cronograma sob controle (o que é um aspecto importante na rotina escolar). Portanto, seções com essa função introdutória não cumprem apenas um papel pedagógico, para facilitar a aprendizagem, mas também visam oferecer ao professor um facilitador do trabalho cotidiano. Isso denota como os livros vão se tornando mais sofisticados e exigindo um trabalho mais complexo para a sua elaboração. 0 reverso dessa moeda é que o trabalho em sala de aula poderá se padronizar, na 
medida em que o professor conferir ao livro a responsabilidade de guiar o seu trabalho.

São interessantes as questões propostas por esses autores no decorrer do texto de um capítulo. Elas podem exigir, por exemplo, a leitura de um mapa-mundi com gráficos aplicados sobre os continentes ou regiões ${ }^{373}$, de modo que o aluno constate a supremacia dos investimentos britânicos na primeira década do século $X I X$, reiterando aquilo que o texto afirma, mas por meio de outra linguagem (cartográfica). Podem fazer com que o leitor se detenha em uma tabela que acompanha o texto sobre a grande depressão, associando os clima pré-Segunda Guerra Mundial com o início da queda do desemprego nos Estados Unidos ${ }^{374}$. Podem, remetendo ao que foi estudado em outro capítulo, formular uma conclusão $^{375}$. Ou podem ainda propor algo bastante ambicioso, como no seguinte caso:

Expliquen el proceso por el cual la Revolución Rusa de 1917 culminó en un régimen burocratico y autoritario. ${ }^{376}$

Esses exemplos servem para indicar também a variedade de tipos de proposição presentes no livro, o que provavelmente deve resultar em maior motivação por parte dos alunos, ao contrário do que provavelmente ocorre diante de uma lista de perguntas que invariavelmente começam com quem, o que, por que, quando, como, que tanto caracterizam os exercícios de verificação de leitura.

Marisa Alonso e equipe dedicam a primeira página de cada capítulo à mobilização do interesse dos alunos. Como apontamos em capítulo anterior, a seção Marco histórico referencial, que abre o capítulo, anuncia os temas que serão tratados, com uma preocupação adicional: no boxe Punto de partida solicita-se que o aluno formule hipóteses sobre o que será essencial, grifando nesse texto o que lhe parece será mais relevante (fazendo uso, naturalmente, de conhecimentos prévios que ele possui), tendo ele, no final do capítulo, oportunidade de verificar se suas hipóteses se comprovaram. Não é comum, nos

\footnotetext{
373 Pirvitéllio, L et. al . Op. cit. p. 95.

374 Idem, p. 170

375 Idem, p. 149. Nesse caso, retomando o capítulo sobre o imperialismo e as rivalidades entre as potências, os alunos poderão chegar às causas da I Grande Guerra.

376 Idem, p. 155.
} 
livros analisados, essa preocupação com a formulação de hipóteses por parte dos alunos. Quase sempre o conhecimento é dado. Mais ainda, em quase todos os livros o aluno deve ter grande dificuldade em compreender como se constrói o conhecimento histórico.

\section{COMPARAÇÕES HISTÓRICAS}

Embora não façam de modo recorrente, Myriam e Patrícia propõem questões em que se entrecruzam a habilidade de comparar, o uso de conhecimentos tratados em outra parte do livro e outros desenvolvidos no próprio capítulo. Um exemplo interessante é o encontrado no capítulo sobre a Revolução Francesa: os alunos são instados a comparar os processos dessa revolução e da Revolução Industrial, dizendo se reconhecem semelhanças e diferenças entre ambos. Num segundo momento, eles devem comparar a atuação de Oliver Cromwell e Robespierre. Algo semelhante é verificado no exercício sugerido por Vicentino e Dorigo no qual se solicita aos alunos que, depois de pesquisarem a biografia de Cromwell, Napoleão, Marx, Lênin e Stalin, comparem semelhanças e diferenças nas trajetórias e nos contextos históricos desses líderes. É deles também a proposta de comparar a reforma urbana levada a cabo em Paris no século XIX, quando se deu nova configuração ao plano urbano daquela famosa cidade, com a configuração da cidade em que eles vivem ${ }^{377}$.

No livro da equipe de Privitellio e dos mesmos dois autores brasileiros, encontramos proposições que fazem com que os alunos acionem conhecimentos adquiridos em outro momento, impedindo-os de pensar que "conteúdo visto, conteúdo esquecido", tão usual quando o enfoque se prende apenas à memorização de informações.

Os autores Pérez, Lara e Romero também sugerem alguns exercícios que exigem comparação. Por exemplo: pedem que comparem as semelhanças e diferenças entre as manifestações de crise no império romano e na atualidade ou que comparem as idéias humanistas durante $o$ renascimento e hoje. $A$ comparação pode ser entre conteúdos estudados, como por exemplo, entre o absolutismo e o despotismo esclarecido ou entre as revoluções de 1830 e 1848. Eles também propõem duas modalidades de comparação comuns a outros livros, 
envolvendo dois ou mais excertos de textos, ou mapas políticos representando as divisões territoriais em dois momentos ${ }^{378}$.

A realização de comparações históricas não é atividade simples, a menos que se fique na superficialidade. Os alunos tendem a entender comparação como "o que há de diferente", chegando às semelhanças apenas quando elas são muito evidentes. Nesse sentido, promover exercícios desse tipo ajuda os alunos a compreender a historicidade de um dado momento, reconhecendo especificidades ou traços comuns a uma outra época ou a outra sociedade. São mais comuns proposições que sugerem a comparação da época estudada com o presente, sobre o qual o aluno supostamente tem maior domínio. Vicentino e Dorigo discutem, por exemplo, o uso dos meios de comunicação de massa no nazismo e hoje no Brasil ${ }^{379}$. Myriam e Patrícia discutem a idéia de partidos de esquerda e de direita na Revolução Francesa e na atualidade ${ }^{380}$.

Encontramos vários casos em que a comparação solicitada dizia respeito a dois ou mais fragmentos de textos. Vicentino e Dorigo, por exemplo, apresentam a Revolta da Vacina a partir de dois pequenos fragmentos extraídos do conhecido livro de Nicolau Sevcenko sobre o tema, a partir dos quais é possível perceber como dois contemporâneos daquele violento conflito o viram de modos diferentes ${ }^{381}$. Mais adiante, fazem algo semelhante com relação à Revolução de $1930^{382}$.

Podemos concluir que é comum à maior parte das obras analisadas a preocupação de desenvolver nos alunos a capacidade de realizar diversos tipos de comparações, sendo essa, portanto, uma competência valorizada no estudo da história. Elas podem variar bastante, podendo mesmo alcançar elevada complexidade. Por outro lado, como observamos no capítulo anterior, também há casos em que apesar do enunciado supostamente exigir dos alunos essa habilidade, eles não encontram subsídios, no texto, para de fato exercitá-la.

\footnotetext{
377 Vicentino, C. e Dorigo, G. Op. cit. pp. 459 e 367 respectivamente.

378 Pérez, A., Lara, G. e Romero, M. Op. Cit. pp. 32, 49, 85, 249 e 291 respectivamente.

379 Vicentino, C. e Dorigo, G. Op. cit. p. 509.

380 Mota, M. e Braick, P. Op. cit. p. 283.

381 Vicentino, C. e Dorigo, G. Op. cit. p. 484.
} 


\section{OUTROS TEXTOS, OUTRAS IDÉIAS?}

Com exceção, mais uma vez, do texto de Marialba Pastor, em todos os livros encontramos outras vozes além das dos autores. Chama atenção, quando se analisa esses excertos, não só a quantidade como a variedade deles em algumas obras, revelando um trabalho cuidadoso dos autores (ou da equipe encarregada dessa tarefa) na busca de textos que complementem e apóiem os seus próprios argumentos. Mas nota-se um traço marcante: não há divergências entre os excertos e o discurso central. Há casos em que dois ou mais excertos contém visões diferentes sobre um determinado fato, e isso é objeto de reflexão. Contudo, não encontramos nenhum caso em que um excerto mostra uma outra visão diferente daquela contida no texto dos próprios autores das obras. Portanto, quando eles entrecortam o seu discurso com o de outros estudiosos, é para reforçar as suas posições. São "discursos de autoridade" que referendam o dito. Logo, as divergências de interpretação são admitidas, mas elas sempre são exteriores ao discurso central dos autores.

Vários deles fazem uso da literatura. Podem fazer bom uso, como por exemplo, pedir que os alunos analisem os versos de Fernando Pessoa em Mar Português, buscando a idéia central do poema e os versos que o aluno considere mais expressivos, o que deve levá-lo a associar com o tema das navegações, estudado no mesmo capítulo ${ }^{383}$. Ou apresentar versos de cordel sobre Getúlio Vargas e solicitar ao leitor que identifique a visão que o cordelista expressou em seu poema ${ }^{384}$. Ou ainda apresentar um belo texto de B. Brecht, em que por meio de metáforas de tubarões e peixinhos se faz uma crítica cortante às desigualdades sociais, pedindo aos alunos que, depois de pesquisar informações sobre o autor, estabeleçam um paralelo com o tema e período estudados (liberalismo e socialismo no século XIX) ${ }^{385}$.

Mas também se pode fazer um mal uso dela, quando, por exemplo, se distorce o texto para que ele se "encaixe" sobre o que se está tratando ${ }^{386}$ ou então

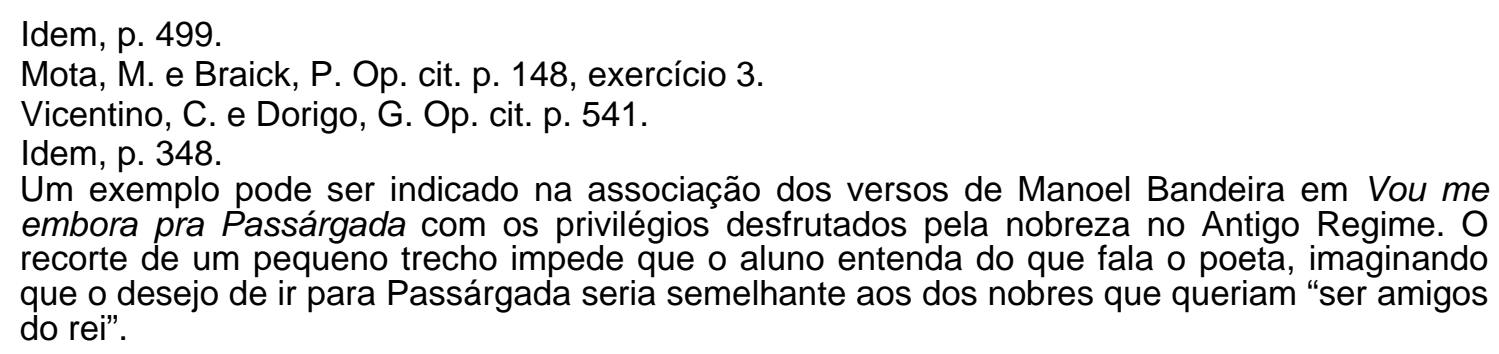


quando não é clara a relação do tema com o texto citado ${ }^{387}$. De todo modo, notase a intenção dos autores de associar história e literatura, levando para a sala de aula uma preocupação de muitos historiadores na academia ${ }^{388}$. Nesse sentido, o livro da equipe de Privitellio inova. No capítulo 10, em que trata da sociedade da segunda metade do século XIX, caracterizando o mundo burguês, especialmente a família, e a realidade dos operários, os autores abrem uma seção Caixa de ferramentas para abordar exatamente a relação entre história e ficção. Informa-se que, entendidos como expressão da cultura, os textos literários são utilizados pelos historiadores para abordar aspectos que de outro modo ficam mais difíceis de serem apreendidos; mas é preciso cuidado, uma vez que os autores não estavam interessados em produzir obras históricas e sim textos literários. Ainda assim, podemos encontrar neles referências sobre aspectos morais, ideológicos, políticos, filosóficos ou estéticos, o que remete aos estilos literários.

Uma lectura adecuada a la tarea del historiador siempre debe intentar ir más allá de la historia narrada para tratar de comprender cuáles son los problemas, las incertidumbres y los interrogantes que preocupan a su autor y cómo son trabajados y desarrollados en su texto. Estos temas que preocupan al autor tienen siempre que ver com la relación de éste con su tiempo. Dado que el escritor es parte de su sociedad y de su época, de algún modo sus temáticas estarán en relación con ella. Como señalan los críticos culturales Beatriz Sarlo y Carlos Altamirano: “ La producción de un autor - cuando más individual se reclame y pese eso - siempre es producto social y práctica de un sujeto socialmente determinado [...] y de una consciencia siempre coletiva". [... $]^{389}$

387 As mesmas autoras, no mesmo capítulo, citam um trecho do livro Memorial do Convento, dando margem ao entendimento equivocado de que a descrição feita por Saramago do ritual noturno de preparação do rei para dormir diz respeito à Idade Média e ao imaginário político daquela época. Mota, M. e Braick, P. Op. cit. p. 127.

De fato, percebe-se um esforço de articular reflexões feitas no âmbito acadêmico e o ensino de História no tocante ao trabalho com literatura. Citamos como exemplo, no Brasil, o artigo de Rafael Ruiz, Novas formas de abordar o ensino de História, na obra já citada História na sala de aula: conceitos, práticas e propostas, p. 75 a 91 e no México, Gustavo Monterrosas Gil, que em sua tese para titulação de professor, propõe o uso de textos literários no estudo da história contemporânea nas classes de secundaria. Ver Gil, Gustavo Monterrosas. La narrativa como auxiliar didactico em la enseñanza de la Historia Contemporanea de México em la educación secundaria. Tesis para titulación de maestro en desarrollo educativo - línea La História e su docência. México:Universida Nacional Pedagógica, 1999. 
Na seqüência, os autores passam a tratar dos romances da época vitoriana, trazendo como exemplo a obra O estranho caso do Dr. Jekyll y Mrs. Hyde, de Robert L. Stevenson, que é indicada para leitura. Há um roteiro de questões, que solicitam desde dados biográficos do autor, até a descrição da residência burguesa do Dr. Jekyll, não deixando de perguntar qual a diferença entre autor e narrador.O salto aqui é evidente, pois não se usa a literatura apenas como um exemplo, mas como fonte histórica. Desse modo, o aluno poderá recorrer em outras situações ao uso de textos literários ou saberá que procedimentos adotar diante de fontes dessa natureza, o que é mesmo o propósito da seção. Note-se, ainda, um outro mérito: professores de História, e não apenas de literatura, indicam leituras literárias para seus alunos ${ }^{390}$.

\section{LEITURAS DE IMAGENS}

No tocante às imagens, é também amplo o espectro de variações encontrado nos livros analisados. No caso do livro de Marialba Pastor, não há um único caso de atividade proposta a partir da imagem (lembrando que nesse livro nem mesmo as legendas ajudam o identificar o que se vê). Os outros autores daquele mesmo país arriscam propor a análise de uma pintura (La infanta Margarida de Áustria, tela de Velázques) ${ }^{391}$, mas os problemas de impressão, que mencionamos mais de uma vez, comprometem a realização da observação.

Nos livros brasileiros encontramos algumas iniciativas semelhantes. No capítulo sobre a cultura medieval, por exemplo, Vicentino e Dorigo apresentam a reprodução de três imagens em tamanho grande (ocupam toda a página), fornecendo um roteiro de análise que levará os alunos a perceber os avanços que Giotto promoveu nas técnicas pictóricas do século XIV ${ }^{392}$.

- Já no caso do livro do grupo de Luciano de Privitellio, não só há diversos exercícios a partir de imagens como há várias seções Cajas de herramientas destinadas a orientar como proceder para se realizar uma análise de imagens históricas. No caso das pinturas históricas, por

390 Os autores vão mais além, pois no boxe que resume o argumento da obra, há referências à cinematografia feita a partir do livro, indicando o filme dirigido por S. Frears como o mais fiel ao texto.

391 Pérez, A. Lara, G. e Romero, M. Op. Cit. p. 69.

392 Vicentino, C. E Dorigo, G. Op. cit. pp. 143-144. Há outros exercícios nas páginas 219, 250 (sugerindo uma interessante comparação entre uma gravura representando a extração de ouro no Brasil e prata em Potosí), 301, 330, 409 (uma foto brasileira do período imperial), 449, 524, 542, 663 (uma charge). 
exemplo, toma-se dois quadros de Jacques-Louis David sobre a Revolução Francesa. Ensina-se a analisar igualmente caricaturas, cartazes políticos, anúncios publicitários e fotografia ${ }^{393}$. Portanto, os alunos não só realizam atividades explorando a iconografia apresentada na obra, como é informado dos procedimentos metodológicos que os historiadores obedecem quando trabalham com esse tipo de documento. Nesse sentido, o aluno realiza o que poderíamos chamar de uma metacognição, pois ele passa a conhecer como se constrói o conhecimento histórico. Esse deixa de ser uma completa "caixa preta", em que nunca se revela com foi possível chegar a tal informação, interpretação ou conclusão. É legítimo supor, além disso, que esse aluno esteja melhor aparelhado para, em outras situações que venha a experimentar, possa fazer uso desses conhecimentos para construir outros. Configura-se assim plenamente o princípio do "aprender a aprender" ou do conhecimento que tem aplicação na vida fora da escola, propósito enunciado, como vimos, nas propostas argentina e brasileira ${ }^{394}$.

\section{TRABALHO COM MAPAS}

Um dos aspectos que mais foi favorecido pelos avanços na produção editorial foi certamente os mapas. A cartografia histórica está presente nos livros desde o século XIX, mas a possibilidade do uso das cores ${ }^{395}$, ferramentas facilitadoras da construção de mapas (barateando o seu custo de produção) e mesmo a maior disposição de Atlas de referência têm propiciado uma expressiva ampliação do número e da variedade dos mapas nos manuais. Continua rara, porém, a exploração deles em atividades, estimulando a leitura cartográfica ${ }^{396}$. Predomina o uso dessa linguagem como forma de facilitar a compreensão de certos temas em que os aspectos espaciais jogam papel especialmente relevante,

393 Privitellio, L. et al. Op. cit. pp. 57,111,165, 175 e 201.

394 A título de exemplo, podemos citar o exercício proposto por Vicentino e Dorigo. Reproduzindo o quadro de David "A morte de Marat", pede que o aluno, primeiro, pesquise a biografia do artista, depois, pesquise o episódio da morte de Marat e, em um terceiro momento, pede que o aluno descreva a pintura e identifique as características do artista, notando se ele foi ou não fiel ao episódio retratado. Vicentino e Dorigo. Op. cit. p. 301.

O fato do livro da Oxford ser impresso em duas cores é um bom exemplo de como as limitações gráfica prejudicam especialmente a reprodução de mapas. Por outro lado, o uso do papel couchê traz grandes ganhos visuais.

396 Isso parece se justificar tanto porque os autores não consideram relevantes exercícios desse tipo como, principalmente, pela dificuldade que eles e os professores encontram para realizar a interpretação dessas figuras. Lembremos que nos cursos de licenciatura há pouca ou nenhuma atenção em capacitar os professores nessas atividades. 
como por exemplo as guerras e os acordos fronteiriços. Nesse sentido, é fundamental o tamanho da área reservada pelo diagramador para a aplicação dos mapas, pois, caso fiquem pequenos ou sobrecarregados de informação, a sua legibilidade é seriamente comprometida. Esse problema, em geral, não foi identificado nos livros.

Merece referência a inclusão de alguns exercícios com mapas bastante interessantes no livro da equipe de Privitellio, como o que demonstra os movimentos do capital durante a primeira década do século $X X^{397}$. Utilizou-se o recurso de aplicação de gráficos do tipo "pizza" sobre as regiões em um mapamundi, solicitando do aluno a leitura desses gráficos. De modo semelhante, a distribuição da atividade produtiva pelo mundo é apresentada em outro mapa por meio de um cartograma, o que faz com que o aluno use seus conhecimentos geocartográficos. Nesse livro também se nota o uso de diferentes projeções cartográficas na confecção dos mapas. No livro de Pérez, Lara e Romero encontramos dois casos em que um seqüência de mapas, procura transmitir ao aluno a idéia de processo/mudança: no primeiro mostra os regimes políticos vigentes no mundo em 1947 e em 1972; o outro mostra o processo de colonização e descolonização da África entre 1890 e 1988, fazendo uso de uma seqüência de seis mapas.

Registre-se que apenas os mapas brasileiros são sempre acompanhados de escala e no caso do livro da Scipione, os mapas têm legenda explicativas, ampliando as informações sobre os mesmos. Registre-se igualmente que os livros argentinos trazem uma nota na página de créditos dando conta de que os mapas foram aprovados pelo Poder Executivo Nacional, conforme determina a legislação daquele país (Lei 22963).

- Chama atenção, por outro lado, a seção com mapas temáticos inserida em diversos momentos ao longo do livro do grupo de Marisa Alonso. Mesmo reservando um par de páginas para ela, ocorre que o texto acaba se sobrepondo aos mapas, a ponto dos primeiros serem mais essenciais do que os segundos para a resolução das questões propostas. Desse modo, a iniciativa de se estimular o trabalho cartográfico acaba bastante comprometida. 


\section{AS TEMPORALIDADES}

Poderíamos estender a análise das atividades, comentando outras modalidades de exercícios encontrados bem como outras preocupações pedagógicas expressas nas obras. Nos livros brasileiros e argentinos, por exemplo, nota-se a preocupação constante de propor situações em que os alunos precisam desenvolver a escrita, procurando desse modo ajudá-los a superar uma de suas maiores dificuldades. Menos comum, mas também presente, é o estímulo à oralidade. Mas a essa altura deve estar bem caracterizada a grande diversidade dos tipos de exercícios presentes nos seis livros, bem como as diferentes abordagens pedagógicas que a caracterizam.

No entanto, consideramos importante incluir a análise sobre mais uma modalidade de exercícios: os que envolvem especificamente o trabalho com as noções temporais. Afinal, esses são os que devem desenvolver o aspecto mais essencial do conhecimento histórico.

A construção das noções temporais é assunto que há muito mobiliza uma boa parte dos pesquisadores dedicados o ensino de História. Tratam-se de noções bastante complexas, exigindo habilidades cognitivas de grau bastante elevado. Mesmo no âmbito historiográfico, vários autores que a tomam como objeto de reflexão enveredam para uma abordagem filosófica, denotado o caráter epistemológico que o tema se reveste.

Como dissemos anteriormente, as teorias piagetianas marcaram profundamente as discussões sobre como trabalhar as diversas noções temporais como crianças e jovens. Segundo alguns, um trabalho mais efetivo só surtiria efeito a partir dos 14 anos, quando o desenvolvimento cognitivo permitiria aos estudantes a compreensão de idéias como duração, anterioridade, sincronicidade. Trabalhos desenvolvidos nos últimos anos, entretanto, já demonstraram as falácias dessa concepção, ficando claro que as crianças são capazes de trabalhar com diversas categorias temporais desde as primeiras séries do Ensino Fundamental, desde que, logicamente, respeitadas as formas como operam seu pensamento, muito egocentrado durante a infância.

Do mesmo modo como os exercícios propostos nos livros servem de suporte para o desenvolvimento de uma série de habilidades dos alunos, cabe também 
verificar que tipo de atividades especificamente associadas às temporalidades são encontradas nos livros.

Para muitos professores de História, o uso das linhas do tempo é o recurso mais comum para fazer com que os alunos elaborem algumas noções temporais importantes, especialmente ligadas à sequenciação de eventos. Myriam e Patrícia propõem, por exemplo, que os alunos construam uma linha do tempo representando os avanços do desenvolvimento da navegação portuguesa ${ }^{398}$. No entanto, o trabalho com as linhas ou as frisas históricas não implicam, necessariamente, no trabalho com as temporalidades.

Mais de uma vez, ressaltamos como a preocupação em fazer com que os alunos estabeleçam relações entre o passado e o presente é marcante em várias obras. Sem dúvida, trata-se de uma questão fundamental para que os aluno compreendam a historicidade de seu tempo. Estabelecer relações entre a expansão comercial e marítima do início do período moderno e o e.comerce, como fazem as mesmas autoras mencionadas acima, sem dúvida contribui para os alunos percebam o que era próprio do seu tempo e de um outro, no passado.

O que é relevante observar é que, apesar desse esforço dos autores, ele tem uma grande e séria limitação: não há por parte deles nenhum cuidado em alertar os alunos de que, se é possível construir a trajetória do capitalismo ao longo dos últimos cinco séculos, essa na verdade é apenas uma forma de entender a vida dos grupos humanos no tempo. Nos seis livros, somente as experiências históricas atreladas ao desenvolvimento capitalista merecem atenção. Nem mesmo se observa que os processos históricos latino-americanos seguiram dinâmicas próprias, em que conviveram mesmo no século $\mathrm{XX}$, por exemplo, grupos sociais cuja vida estava regulada pelo tempo do relógio ( o tempo da fábrica) com outros ainda regidos pelo tempo da natureza. Tudo se reduz a uma só trajetória histórica.

Também não há menção explicita às idéias de duração e sincronicidade, por exemplo. Mesmo nos dois livros brasileiros, em que correm "paralelas" a História Geral e a do Brasil, há a preocupação de se realçar essas duas noções, ainda que os professores possam faze-lo durante as aulas. 
É forçoso reconhecer, assim, que ainda não estão presentes nos livros didáticos algumas questões que têm mobilizado os historiadores e que diversos pesquisadores do ensino de História tem chamado atenção para sua importância. $O$ tempo homogêneo e contínuo, que nos liga aos mercadores do século $X V$, aos revolucionários franceses e operários do século XIX, é o que prevalece. Nossa análise nos leva a concluir que, para esses autores, a construção das noções temporais será o resultado, quase "natural", do estudo da História.

\section{AVANÇOS E PERMANÊNCIAS}

Segundo Chervel,

Se os conteúdos explícitos constituem o eixo central da disciplina ensinada, o exercício é, em contrapartida quase indispensável. A inversão momentânea dos papéis entre o professor e o aluno constitui elemento fundamental desse interminável diálogo de gerações que se opera no interior da escola. Sem o exercício e o seu controle, não há fixação possível de uma disciplina. O sucesso das disciplinas depende fundamentalmente da qualidade dos exercícios aos quais elas podem se prestar ${ }^{399}$.

Livros didáticos, necessariamente, são concebidos e desenvolvidos tendo como proposta uma ou mais das concepções de ensino acima mencionadas - ou ainda outras - podendo tal abordagem ser mais ou menos explícita, mais ou menos bem executada. As seções que compõem uma obra, e em particular aquelas destinadas às atividades, têm por finalidade estabelecer uma determinada metodologia (e uma dada rotina de estudos), que visam assegurar o cumprimento de tais objetivos, o que acaba estabelecendo, ao menos teoricamente, o espaço de atuação do professor, que pode ser de maior ou menor autonomia. Essas seções tendem a fornecer um certo protocolo de uso do livro, ainda que não obrigatoriamente tenha de ser obedecido ${ }^{400}$. Por isso, dois ou mais professores podem usar o mesmo livro e ainda assim ter objetivos distintos. Também pode ocorrer de mesmo professor usar dada obra e estabelecer objetivos distintos para uma e outra temática.

399 Chervel, A. Op. cit. p. 204.

400 Seções como a que vemos no livro da Editora Puerto de Palos do tipo " A organização deste livro" tendem a explicitar esses protocolos, bem como os Manuais do Professor que acompanham algumas obras. 
Entretanto, é legítimo supor que ao adotar um livro didático como recurso de apoio sistemático para suas aulas, o professor escolha aquele que possua (ou que ele pensa possuir) os objetivos mais próximos dos seus, proponha estratégias que ele sinta maior segurança em desenvolver e que sejam ainda compatíveis com a sua realidade escolar (o que explica porque um mesmo professor pode adotar livros diferentes para cada uma das escolas em que leciona). Ou seja, é pouco provável que os professores chamados "conteudistas" (ou que trabalham em escolas que privilegiam os conteúdos), por esperarem que seus alunos "saibam" um grande volume de informações, escolham como obra de apoio uma que privilegie apenas algumas temáticas históricas a partir da formulação de um problema e estimule o trabalho do próprio aluno para resolvê-lo. Do mesmo modo, um professor que valoriza o domínio de conceitos não deve se sentir atraído por obras que tragam uma longa seção de questionário de mera verificação de leitura ou que sugiram muitas atividades lúdicas. Isso explica, em parte, porque uma mesma editora pode ter em catálogo mais de um título para o mesmo segmento. A existência de grande número de livros didáticos de uma disciplina em um país, contudo, não é indicativo de abordagens diversas, pois pode haver grande semelhança entre os mesmos ${ }^{401}$.

Temos elementos para acreditar que as diferenças marcantes nos tipos de exercícios encontrados nos livros dos três países revelam que o ensino da História desenvolvido por muitos professores de cada um deles (lembremos que estamos analisando os líderes de venda) também apresenta expressivas diferenças. No México, os indícios são de um ensino atado à informação. O que os alunos "precisam" saber depende mais da memória do que propriamente da compreensão. A julgar pelos dois livros brasileiros, esse tipo de preocupação também está presente em nossas salas de aula, mas ela não é a única. Já na Argentina a análise dos dois livros nos faz supor que naquele país os debates em torno do ensino de história, contemplando tanto questões da própria História como do seu ensino, conseguiram ultrapassar o âmbito dos "especialistas", chegando aos livros e possivelmente à prática dos professores. Nossas hipóteses, naturalmente, precisam ser confirmadas com estudos empíricos, mas se acreditamos que os livros didáticos desempenham realmente papel relevante na

401 Apesar de não termos uma avaliação mais acurada do conjunto dos livros mexicanos para o ensino médio, o caso desse país parece ser um exemplo desse caso, uma vez que encontramos muitos livros em que as informações se sobrepõem aos aspectos pedagógicos. 
constituição dos currículos, é bem possível que elas se confirmem em muitas salas de aula.

Vendo as seis obras em conjunto, percebemos que todas tratam de modo especial as aberturas de unidades e capítulos, tanto do ponto de vista gráfico/visual como pedagógico. Seria interessante verificar se essa preocupação é mais dos autores e editores ou se de fato eles fazem isso porque os professores consideram esse momento importante no processo de ensino-aprendizagem de seus alunos, podendo vir a escolher um livro por essas seções ${ }^{402}$. De fato, todas as orientações pedagógicas em voga defendem a necessidade de se realizar uma aproximação cuidadosa do aluno para com o tema a ser estudado, disso resultando melhor aprendizagem. Realizadas de modos variados, os livros, independentemente de sua nacionalidade, procuram atender a essas recomendações. Podemos dizer que basicamente há três modelos para essa introdução, que podem inclusive se misturar: uma, aponta as idéias centrais contidas no capítulo, outra, apresenta um texto-síntese com as idéias principais, que serão desenvolvidas no capítulo, e uma terceira propõe questões problematizadoras. Nesse último caso, nota-se uma conexão mais clara entre os aspectos pedagógicos como os da disciplina, pois em ambas está presente a idéia da problematização ${ }^{403}$.

Um segundo ponto relevante é que as atividades deixaram de ser um mero complemento do texto, quase uma formalidade. O modelo do clássico questionário ao final do capítulo, em que o aluno apenas busca no texto as respostas para as perguntas está claramente superado na Argentina e no Brasil, mas ainda vigora, com algumas variações, no México.

402 Chervel, a propósito dessa questão das práticas de motivação e de incitação ao estudo, diz que a sua história "atravessa de lado a lado toda a história das disciplinas", ou seja, conhecer e compreender como os professores (e também os livros) procuram estimular o estudo de um novo tema é um aspecto relevante quando se procura compreender a trajetória de uma disciplina escolar. Chervel, A. Op. cit. p. 205.

403 Schimidt e Cainelli fazem uma distinção importante entre a problematização do conhecimento histórico, em geral estabelecendo alguma relação entre o passado e o presente, e a problematização como estratégia pedagógica. Embora ambas tenham a ver com aspectos metodológicos, tratam-se de âmbitos distintos. Schmidt, Maria Auxiliadora e Cainelli, Marlene. Op. cit. p. 52-53. 


\section{CONCLUSÃO}

A escola pouco aprende que a história que ensina não é "o" passado, mas um

modo de ver o passado.

Suzanne Citron

Chegando ao final de nosso percurso, coloca-se o desafio de sistematizar uma série de considerações feitas anteriormente, de modo que possamos identificar que concepções de história e de ensino de História estão presentes nos livros cujas vendagens em seus países os tornam líderes de mercado, fazendo crer que muitos jovens estudam por meio deles. Ainda que as visões dos alunos não sejam as mesmas dessas obras, de algum modo elas contribuem para que esses jovens construam uma certa idéia de História.

Nosso esforço ao longo deste trabalho foi apontar e articular um conjunto de aspectos que nos permitisse uma análise para além dos livros em si. Isso porque nosso propósito principal é demonstrar que, além de estarem inseridas em uma intrincada rede de relações, os livros didáticos constituem uma modalidade específica de texto, que não deve ser analisado apenas sob um aspecto. Nesta parte final, queremos realçar como as concepções de História e do seu ensino estão profundamente interligadas, resultando inevitavelmente em uma determinada configuração do livro didático.

\section{HISTÓRIA GERAL: HISTÓRIA DA HUMANIDADE OU UMA HISTÓRIA DO CAPITALISMO?}

A primeira constatação relevante que podemos fazer após analisar os seis livros é que nos três países o eixo estruturante do curso de História Geral para o Ensino Médio é a História do capitalismo. Exatamente por isso, a ênfase recai sobre o período contemporâneo. A História do século XX ocupa expressiva parte dos programas, mesmo no caso brasileiro, em que ainda se preserva a tradição 
de iniciar os estudos pela chamada Pré-História. Podemos dizer que a Europa continua sendo vista como o centro e o motor da história, pois é desde lá que as forças capitalistas se expandem de maneira quase sempre contínua, pelo menos até a segunda metade do século XIX, quando passa a dividir essa supremacia com os Estados Unidos. Considerando que todos os autores admitem que uma das funções do estudo da História é compreender melhor o mundo em que vivemos, podemos concluir que para compreendê-lo é essencial entender as transformações havidas nos dois últimos séculos em decorrência da instauração da ordem capitalista. Esse processo foi marcado por dois tipos de conflitos: o primeiro foi resultante do antagonismo entre burguesia e operariado, mas que se estiolou frente a uma outra ordem de confrontos, agora entre as nações. Esses conflitos, por sua vez, se dividem em dois tipos: ideológicos (democracia $x$ totalitarismo e, depois, capitalismo $x$ socialismo) e econômicos (potências capitalistas $x$ países periféricos) ${ }^{404}$. Os processos históricos resultam, pois, das dinâmicas desses conflitos, geralmente apresentados de modo binário. A América Latina é espaço privilegiado para se compreender os mecanismos de dominação e subordinação impostos pelas potências, que os livros mexicanos e brasileiros procuram caracterizar de modo bastante generalizante. Daí decorre que a história dos povos dessa região respeita uma lógica que lhe é sempre exterior. De igual modo, as referências à história dos povos africanos e asiáticos só se fazem presentes quando subsumidas ao processo capitalista conduzido pelos europeus.

Por outros caminhos, é a "história dos vencedores" que ainda se impõe, mesmo que se procure ser crítico à forma como eles venceram. Não há, desse modo, espaço para conhecer outras temporalidades que não estejam subordinadas ao tempo único do capital. E aqui talvez possamos identificar um processo de reacomodação de uma tradição. Se na perspectiva humanista o estudo da História se subordinava à formação geral do indivíduo, que deveria conhecer a trajetória civilizacional das sociedades ocidentais, desde a Antiguidade, essa perspectiva temporal mais longa perdeu relevância, considerando-se suficiente que o aluno conheça o processo pelo qual a ordem capitalista se estabeleceu, expandiu-se e consolidou sua dominação. Portanto, estamos nos distanciando cada vez mais do modelo da formação humanista, da valorização do domínio de uma cultura clássica.

404 Registre-se que os autores caracterizam o conflito entre capitalismo (e não liberalismo) e socialismo como predominantemente ideológico. 


\section{A HISTÓRIA COMO DISCIPLINA ESCOLAR}

Raymundo Cuesta Fernández, ao estudar o processo de criação e institucionalização da História como disciplina escolar na Espanha, observou que na verdade as disciplinas em geral, e a História em particular, estão constantemente se reinventando, num processo não linear em que interferem fatores culturais, sociais e políticos. Ainda assim, é possível verificar que a cada época vigoram o que ele chamou de código disciplinar, definida como um conjunto de idéias, valores, suposições, regulamentos, rotinas práticas (tanto de caráter expresso como tácito), que em geral se transformam em discursos legitimadores e em linguagens públicas sobre o valor educativo da História. O código disciplinar seria, assim, uma espécie de tradição social, que comporta uma reinvenção e uma reelaboração do passado, segundo condicionantes históricas ${ }^{405}$.

Os livros analisados nos dão elementos para acreditar que, no presente, o código disciplinar de História transita entre três paradigmas:

i) O conhecimento histórico possui um valor em si mesmo; quem o detém adquire atributos de distinção social e cultural (homem culto).

ii) O conhecimento histórico é parte da formação do cidadão; por meio dele os indivíduos se apropriam de valores fundamentais para a vida social, especialmente associados às identidades e a uma perspectiva crítica do mundo.

iii) O conhecimento histórico é um recurso para o desenvolvimento cognitivo do indivíduo. O seu estudo proporciona o desenvolvimento de uma série de habilidades e competências necessárias para a vida adulta e sem as quais a autonomia intelectual dos indivíduos e sua formação para o trabalho não se efetivam.

O primeiro paradigma era o que vigorava de modo dominante quando o Ensino Médio era restrito a uma pequeníssima parcela de jovens, que viria a constituir a elite social. Ocorre que, como vimos, tanto no Brasil, como no México e na Argentina, há um grande esforço em se universalizar o acesso a esse nível escolar, o que obriga a inclusão de largos setores sociais aos sistemas de ensino.

405 Cuesta Fernández, Raymundo. Sociogénesis de uma disciplina escolar: la Historia.. Barcelona: Educaciones Pomares-Corridor, 1997, p. 86. 
Para esses setores, a História apresentada segundo esse paradigma não faz sentido, pois lhe é completamente alheia. Não por outro motivo, os dois outros paradigmas vão se impondo, uma vez que mais coadunados com as novas finalidades postas para a escola.

O que nos chama atenção é que se no passado o ensino de História estava profundamente associado à construção das identidades nacionais, conferindo à história pátria espaços privilegiados nos programas, nesse momento, e de modo especialmente marcante no Brasil, a História Geral parece merecer maior atenção. Talvez nesses tempos de globalização, tão ou mais importante do que tratar das identidades nacionais seja construir uma "identidade mundial". Para tanto, os legados culturais greco-romanos, do cristianismo e do racionalismo iluminista deixaram de ser componentes centrais como eram no passado. O mercado é a nova entidade que unifica a todos. Daí porque parece ser relevante destinar as aulas de História para os jovens do Ensino Médio ao estudo da gênese, desenvolvimento, expansão e consagração do sistema capitalista, ainda que, adotando-se uma perspectiva crítica e reconhecendo as inúmeras mazelas que ele tem provocado. Se antes a "História oficial" dos Estados Nacionais é o que conferia identidade aos indivíduos de um país, agora a "comunidade imaginária" a se forjar é a dos integrantes do mercado global. E para tanto a História escolar é chamada a contribuir.

Identificamos, nesse sentido, variações expressivas nas abordagens, no grau de aprofundamento dos temas e na abrangência deles, sendo visível a diferença nas obras argentinas, em que já se nota uma atenção maior aos aspectos sociais e culturais, frente às brasileiras e mexicanas, nas quais os aspectos políticos e econômicos ainda são mais relevantes (ainda que nos PCNs brasileiros se enfatize a necessidade de se ampliar o estudo das questões culturais). Mesmo nos livros argentinos, em que há uma ampliação desses aspectos, verifica-se ainda pouco espaço para temas como o das festas, do lazer, da brincadeira, do amor e o do namoro, para os jogos e a música, temas que são de interesse dos jovens. Constatamos que os livros de História continuam não contemplando temáticas que estão mais próximas da cultura juvenil, como recomendam diversos 
autores $^{406}$. Não se fala igualmente da morte, da vida espiritual (religiosa). A Igreja aparece apenas como instituição política. As manifestações artísticas aparecem, mas a elas são reservados especialmente os espaços das imagens. A contracultura, curiosamente, é quase desprezada: 68, os Beatles, o rock praticamente não são mencionados.

Em todos os livros, contudo, a esfera social merece relevo. Por outro lado, esse social muitas vezes se confunde com o nacional, o que reforça a centralidade do Estado como agente histórico. A idéia de conflito é permanente, mas a de resistência aparece muito pouco. A historicidade dos grupos sociais é pouco explorada, predominando visões bastante homogêneas. Não há praticamente distinção entre os operários do século XIX e os trabalhadores do século XX. No caso do Brasil, os movimentos operários merecem atenção quando se trata das primeiras décadas da República e só voltam a ter maior destaque com as lutas pela redemocratização, no final dos anos 1970, dando a entender que de fato o período varguista teria posto fim às lutas operárias. Na Argentina essas lutas se prolongam até a morte de Perón. Nos países desenvolvidos, entretanto, eles desaparecem na virada do século XIX para o XX.

Outro traço comum é a preocupação com o presente, embora ele seja compreendido de modos diferentes. Pode ser ponto de partida - estabelecendo uma problemática que remeta ao passado -, ou ponto de chegada. Nos livros argentinos e brasileiros, o desenvolvimento dos conteúdos dá-se em torno de problemas ou de questões (ressalvando que essas problematizações nos livros brasileiros têm caráter metodológico no tocante ao ensino/aprendizagem e menos relação com a própria ciência de referência, fato diverso ao verificado no livro elaborado pela equipe de Luciano Privitellio, em que essas duas dimensões se cruzam) e para os quais a história pode oferecer, ou ajudar a oferecer, respostas. Nesse sentido, parecem pertinentes os comentários de Marc Ferro quando reconhece que no século XIX fundaram-se duas tradições historiográficas que parecem ter deixado heranças na historiografia didática: uns explicam o presente através do passado e outros estabeleceram um inventário de acontecimentos que conduzem ao presente, "com essa história factual banalizando o acontecimento atual, visto que, assim que anunciado, torna-se passado [...]. Todos os fatos, 


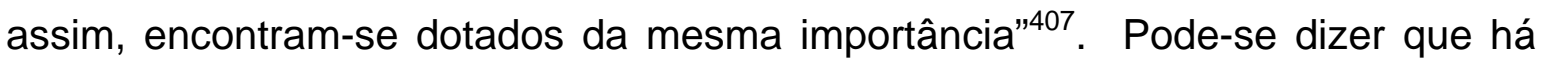
mesmo uma certa pasteurização dos acontecimentos nos livros didáticos, que perdem qualquer hierarquia de relevância quanto mais próximos eles estão da atualidade. Daí o que chamamos de "abordagem de almanaque", no sentido que a força explicativa e a importância dos fatos residem neles mesmos.

Estão subjacentes nos livros as noções de duração, processo, transformação, permanência e mudança. Mas elas não são pedagogicamente destacadas, sendo poucas as atividades em que são enfatizadas. O trabalho com as temporalidades resume-se basicamente à relação passado x presente. Tem-se a impressão que a compreensão das noções temporais, como duração, anterioridade, sincronicidade, conjuntura, etc. será o resultante, o produto das aulas. Por outro lado, essa preocupação dos autores em promover uma constante relação entre passado e presente, nos faz indagar: até que ponto o foco no presente não seria uma expressão do que Hobsbawm denomina de "presentismo", tão forte na atualidade, sobretudo entre os jovens, que centram permanentemente suas vidas no "aqui e agora". Como conseqüência, parece que perde qualquer sentido o estudo de um passado que não tenha vínculos com o nosso tempo, com as nossas inquietações.

As seis obras pressupõem papéis centrais aos professores, mas o tipo de atuação seria muito diverso. Pode caber a ele a função de esclarecer, explicar ou até mesmo revelar os sentidos e os significados do texto. Alguns livros ainda concebem o professor como aquele que "completa e vivifica o texto", como dizia Joaquim Manoel de Macedo ${ }^{408}$. Em outros, o professor desempenha mais o papel de mediador.

Ligado a esse aspecto, constata-se uma variação importante quanto ao grau de determinação do trabalho do professor pressuposto nas obras, considerando as proposições, os tipos de seção e de atividades presentes nos livros. Há livros, como os dois mexicanos, em que o professor encontra grande autonomia, pois basicamente o livro é um texto, seguido de um questionário, até propostas mais "amarradas", como os dois livros argentinos, em especial o da Puerto de Palos,

407 Ferro, Marc. Historia vigiada. São Paulo: Martins Fontes, p. 110.

408 Apud Bittencourt, Circe. Livro didático e conhecimento histórico: uma história do saber escolar. Op. cit. p, 272. 
em que o livro tende a impor uma certa metodologia. Os dois livros brasileiros estariam em um nível intermediário, ainda que eles tendam a conferir aos professores mais autonomia do que amarras, o que se explica pela diversidade de carga horária e de programas em vigor no país. Nesse sentido, retomando o que dissemos na Introdução, as obras parecem ser suficientemente abertas tanto para os professores trilharem caminhos próprios como para adaptar a obra à sua realidade de trabalho ${ }^{409}$. Essa marca possivelmente se explique por se tratar de livros de circulação nacional, cuja utilização se dá em ambientes sociais e escolares muito diversos. Por outro lado, possivelmente essa flexibilidade pode ser vista como um atributo positivo para os professores, sendo essa uma das razões pelas quais elas são líderes de vendas.

As atividades não privilegiam apenas a memorização. Vários autores consideram a etapa da verificação da leitura relevante; outros, não, chegando mesmo a não incluir exercícios com essa finalidade e dando espaço a outras modalidades de atividades, em que o papel dos alunos é muito mais ativo. Podemos dizer que os livros analisados, em diferentes graus, contribuem para que a sala de aula se torne um "espaço onde a palavra, a ação, a liberdade e o intercâmbio sejam verdadeiramente possíveis", como aspirava Claudia Ricci há cerca de 15 anos $^{410}$.

Quando lembramos que mais da metade dos alunos mexicanos dizem não ter certeza da utilidade do que estudam em História e vemos as características do livro de Marialba Pastor, a opinião dos alunos não causa tanto estranhamento. Já nos livros brasileiros verifica-se uma oscilação no padrão interpretativo. Enquanto em alguns capítulos há maior ênfase no próprio desenrolar da história, como se ele próprio fosse auto-explicativo, em outros a análise se adensa, procurando articular uma série de aspectos ou mesmo se procura demonstrar como dois ou mais grupos, portadores de diferentes projetos, enfrentavam-se. Em alguns momentos as explicações são mais esquemáticas, resvalando até mesmo no

409 Luciana Telles Araújo, investigando o uso do livro didático, aponta que, ao menos no EF, os professores utilizam essas obras com liberdade, ainda que seus planejamentos reflitam grande vínculo com a organização dos conteúdos dos livros. Araújo, Luciana. O uso do livro didático no ensino de História: depoimentos de professores de escolas estaduais de ensino fundamental situadas em São Paulo. Pontifícia Universidade Católica de São Paulo, 2001. Dissertação de mestrado.

410 Ricci, Cláudia S. "A academia vai ao ensino de $1^{\circ}$. e $2^{\circ}$ graus". Revista Brasileira de História., v. 19 , no. 19 , p. 135-142,1989/1990. 
simplismo, enquanto em outras a história se complexifica. Pode-se dizer que aqueles conteúdos que servem de ligação entre uma temática e outra (por exemplo, as revoluções liberais do século XIX) tendem a ser bastante simplificados, enquanto outros, tomados como mais relevantes, ganham maior aprofundamento (como é o caso do mundo bipolarizado da Guerra Fria). No livro de Luciano de Privitellio verifica-se uma maior coesão explicativa. Já no caso da obra de Marisa Alonso e equipe, como abarca-se um conjunto de temas mais amplo, o que se altera no decorrer do volume são os aspectos privilegiados, sobretudo na seção temas y paradigmas. Nos livros brasileiros, concebidos para serem usados por três anos, não se pode dizer que as análises se tornem mais complexas em gradação crescente conforme a série cursada; o grau de dificuldade relaciona-se mais à complexidade do próprio tema.

Retomando as considerações de André Chervel, o sistema escolar e, por extensão, as disciplinas, não formam apenas os indivíduos, "mas também a cultura que vem por sua vez penetrar, moldar, modificar a cultura da sociedade global" ${ }^{411}$. Por isso, conceber a História da Educação e mais ainda uma História das disciplinas nos marcos de uma História cultural nos ajuda a entender como interagem sociedade e sistema educacional, contribuindo tanto para a preservação como para a mudança de práticas sociais. Assim, se ao longo dos três últimos capítulos apontamos a manutenção de muitas tradições no ensino de História, identificamos igualmente mudanças, inovações, tentativas de se ir além do que tem sido comum. Isso no leva a concluir que, ainda que em graus variados, na Argentina e no Brasil a disciplina de História passa por mudanças, forjando uma nova cultura histórica escolar. Nos três países procura-se incorporar novos temas nos programas escolares, alargando a idéia de História. Um exemplo pode ser a inclusão nos livros de considerações sobre a História da educação no passado isso só merecia menção quando se falava da educação em Esparta -, com considerações sobre a implantação dos sistemas educacionais, mostrando como eles correspondiam à necessidade da consolidação dos Estados Nacionais. Até mesmo Marialba Pastor, muito refratária a qualquer mudança na abordagem histórica, inclui uma referência sobre isso. Para Chervel, "uma disciplina é [...] para nós, em qualquer campo que se encontre, um modo de disciplinar o espírito, quer dizer, de lhe dar os métodos e as regras para abordar diferentes domínios do

411 Chervel, A. Op. cit. p. 184. 
pensamento, do conhecimento e da arte" ${ }^{412}$. Os livros didáticos analisados apontam, de modo congruente com as grandes orientações educacionais, para um ensino que procura associar o domínio de informações com um conjunto de habilidades e competências, tanto cognitivas como metodológicas (saber analisar um mapa, localizar-se ou fazer uma linha do tempo, reconhecer um documento histórico, etc.). Essas habilidades e competências capacitam os alunos a construir novos conhecimentos.

Os livros oferecem situações que levam os alunos a aprender a trabalhar com variadas fontes históricas, o que poderá levá-lo a compreender como se constrói o conhecimento histórico. O limite, no entanto, é saber como se elabora o conhecimento veiculado pelo próprio livro, uma vez que quase não há indícios das razões da seleção desses conteúdos, tampouco dessa organização. Fala-se de eventuais divergências entre os historiadores, mas nunca se confronta o que os autores afirmam com outras interpretações. Nesse sentido, continuam procedentes as considerações de Gimeno Sacristán ${ }^{413}$, quando diz que falta aos livros didáticos um metadiscurso, por meio do qual os alunos tomem conhecimento dos problemas, teorias, análises e fontes usados na sua elaboração. Os textos são sempre taxativos, nunca aparecendo expressões como "parece que ...", "aparentemente...", "pode ser que...", "provavelmente...". Portanto, a mudança do foco da informação para o conhecimento propriamente parece ainda distante. Se conseguimos desenvolver os conteúdos a partir de problematizações, ainda não foi possível instaurar entre os alunos a convivência com a dúvida, a incerteza, a inquietação. A questão a saber é se, pela sua própria natureza, os livros didáticos um dia de fato assumirão essas características que cobra o educador espanhol.

Tanto Chervel como Forquin ${ }^{414}$ apontam para a mesma direção: a finalidade última da educação é transmitir às futuras gerações "nosso testamento"; as disciplinas escolares têm sido o modo pelo qual a nossa sociedade tem realizado essa tarefa. No caso do ensino de História esse papel é muito evidente, pois explícito. Marc Ferro diz que cabe ao historiador primeiro conservar e, depois,

412 Idem, p. 180

413 Sacristán, G. Op. Cit. P. 108.

414 Forquin, Jean-Claude. Escola e cultura.As bases sociais e epistemológics do conhecimento escolar. Porto Alegre: Artes Médicas, 1993. 
tornar inteligível a história ${ }^{415}$. Podemos concluir, então, que hoje os livros de História pretendem conservar, difundir e explicar uma dada versão da trajetória do mundo ocidental, segundo a qual o capitalismo, surgido nos primórdios da Idade Moderna, precisou dos últimos dois séculos para estender seus tentáculos por todo o planeta. Compreender esse percurso é compreender o que somos hoje. Portanto, se ao se estudar a História pátria se traça uma genealogia da nação, quando se estuda a História Geral o que é vemos é também uma certa genealogia de um sistema econômico que se impôs, não mais apenas em nome do progresso (já que esse está em crise há várias décadas), mas pela sua capacidade de unificar o mundo. A globalização seria, ao mesmo tempo, o apogeu e um momento crítico dessa trajetória, na medida em que o mundo nunca foi tão desigual. É desse presente, com esse passado, que se deverá construir o futuro.

\section{AS PROPOSTAS CURRICULARES E OS CONTEÚDOS DOS LIVROS}

Quando se confrontam as propostas curriculares vigentes no Brasil e na Argentina com os conteúdos dos livros, verificamos que enquanto na Argentina autores e editores procuraram desenvolver suas obras segundo os marcos referenciais estabelecidos pelas propostas, obras essas que foram expressivamente adotadas pelos professores, no Brasil não se verificou o mesmo. Ao contrário, as obras mais vendidas estão muito distantes do modelo curricular prescrito. No México, o que constatamos é que, na falta de currículos nacionais (dada a total descentralização administrativa da Educação Média Superior), os programas das Escolas Nacionais Preparatórias e dos Centros de Ciências Humanas, ambos vinculados à UNAM, converteram-se em referência e os livros os seguem com enorme rigor.

Retomando uma questão posta por André Chervel - indagar por que a escola ensina o que ensina, no lugar de se perguntar o que a escola deveria ensinar para satisfazer os poderes públicos ${ }^{416}$ - coloca-se um problema muito interessante: por que na Argentina as reformas curriculares foram rapidamente absorvidas pelos autores e editores, convertendo-se nos currículos ativos (já que os livros analisados são os líderes de venda), enquanto no Brasil isso não ocorreu e no México as reformas ocorridas nos anos 1990 não atingiram esse nível escolar?

415 Ferro, Marc. História Vigiada. São Paulo: Martins Fontes, 1989, p. 124.

416 Chervel, André. Op. cit. p. 91 
Seria apenas decorrência de docentes mais conservadores no caso de nosso país e, mais ainda, no México ${ }^{417}$ ?

Não dispomos de elementos para responder a essas questões, mas podemos esboçar uma hipótese.

Luis Alberto Romero afirma que na Argentina as editoras desde os anos 1980 recorreram sistematicamente a docentes e investigadores universitários que haviam promovido inovações em seus respectivos campos de atuação de modo que os livros didáticos passassem a ter novos enfoques, introduzindo ou aprofundando temas antes periféricos. Além disso, muitos dos que participaram das discussões sobre as reformas curriculares se envolveram com a produção didática. Outras modificações se deram na própria concepção do livro didático: textos mais curtos, maior número de imagens, boxes, inclusão de resumos, atividades complementares, associados a projetos visuais inovadores, fazendo mais uso das cores. As obras passaram a ser produzidas por equipes editoriais, segundo modelos europeus, particularmente espanhóis. O apelo ao novo tornouse mote na concorrência entre as editoras, o que rompeu com a tradição e o domínio de antigas casas editoriais argentinas ${ }^{418}$. Verificou-se, portanto, a conjugação de uma série de fatores de ordem acadêmica, curricular/governamental, editorial e mercadológica da qual redundou a publicação, entre outras obras, das duas que analisamos. Uma, publicada pela Editora Santillana, subsidiária da matriz espanhola, informa na página de rosto que a obra é um projeto editorial seu, desenvolvido por uma equipe liderada por Luciano de Privitellio (historiador ligado à Universidade de Buenos Aires e envolvido com os debates sobre o ensino de História). A outra, editada por uma empresa argentina, a Puerto de Palos, também foi desenvolvida por uma equipe de autores, sob liderança de Marisa Alonso (com atuação semelhante a de Privitellio, mas integrante de um outro grupo acadêmico). Ambos os livros integram coleções compostas de volumes para todas as disciplinas do Polimodal, seguindo todos uma mesma estrutura.

417 No capítulo 1, dissemos que na Argentina e no Brasil há indicadores de que os professores são mais jovens do que os do México e isso repercute nas mudanças curriculares, como observa Chervel quando comenta que a taxa de renovação docente tem implicações diretas nas mudanças curriculares. Chervel, A. Op. Cit. p. 197.

418 Romero, Luis Alberto (Coord.). La Argentina em la escuela. La Idea de nación en los textos escolares. Buenos Aires: Siglo XXI, 2004, pp. 3, 32 e 150. 
No Brasil, as boas escolas - particulares ou públicas - do Ensino Médio, para as quais se destinam basicamente as obras analisadas - pois lembremos que só muito recentemente começou a ocorrer programas de compras governamentais para esse nível de ensino -, preservaram os cursos com função eminentemente propedêutica. Seu principal papel continuou sendo o de preparar os alunos para os exames vestibulares, sobretudo das instituições públicas, onde a concorrência é em geral maior. Como observou Paulo Eduardo Dias de Mello, mesmo naquelas escolas cujos alunos não dispõem de condições para efetivamente brigar por uma vaga nas melhores universidades, geralmente jovens trabalhadores, muitos professores seguem esse mesmo modelo ${ }^{419}$. Como o perfil dos vestibulares até este momento não mudou, de modo a contemplar as proposições dos PCNs, as poucas obras que foram publicadas atendendo as propostas não tiveram repercussão comercial $^{420}$. Mostrou-se correta a previsão de que os professores não se engajariam em reformulações tão profundas de seu trabalho, para as quais muitos não dispunham nem mesmo de formação ${ }^{421}$. Sem contar as condições de trabalho que enfrentam, que pouco estimulam grandes mudanças ${ }^{422}$.

$\mathrm{Na}$ Argentina, ao contrário, onde o acesso a Universidade é mais democratizado, esse nível de ensino não tem os mesmos objetivos e, possivelmente, torna-se menos difícil mudanças curriculares, sobretudo quando elas estão em consonância com os debates acadêmicos, com os da sua ciência de referência e as orientações educacionais dominantes. Desse modo, a adesão ao princípio do "aprender a aprender" parece não ter encontrado grandes resistências, a ponto de uma obra com essa proposta assumir a liderança de vendas.

419 Mello, Paulo Eduardo Dias. Vestibulares e currículo: saber histórico escolar e os exames vestibulares da FUVEST. Faculdade de Educação da Universidade de São Paulo, 2000, Dissertação de mestrado, p. 11. O autor observa que segundo os professores "preparar para o vestibular" seria o melhor caminho para eles "subirem na vida".

Dentre as obras que procuraram formular uma nova organização dos conteúdos, chegando mesmo a romper com a formatação de um volume único, podemos citar a coleção organizada por Leo Stampachio, publicada pela Editora do Brasil, composta por pequenos cadernos com módulos de conteúdos.

Considere-se, entretanto, que as novas abordagens historiográficas também não se coadunam com o ensino de "toda a História", verificando-se um hiato entre a formação acadêmica de muitos professores e as suas necessidades para desempenhar suas funções.

422 A conclusão é mais curiosa quando lembramos que os PCNs têm proposições mais radicais no sentido de inovações do que as propostas argentinas, onde, grosso modo, os conteúdos clássicos foram preservados, revendo-se mais sua abordagem. Isso parece comprovar a afirmação de Chervel de que sempre há um hiato entre o que determina a legislação (que tenderia mais a "corrigir um estado de coisas" e a educação efetivamente oferecida, apesar do caso argentino parecer uma exceção. Há, naturalmente, a necessidade de se verificar com estudos empíricos esses indícios. Cf. Chervel, A. Op. cit. p. 190. 
Por outro lado, ao contrário do que apontavam alguns críticos das reformas curriculares, como Alice Casimiro Lopes ${ }^{423}$, não se pode dizer que o ensino de História se submeteu à lógica do mercado de trabalho, preocupando-se mais com as competências do que com o domínio dos conteúdos. Nenhum dos livros coloca os conteúdos a serviço de outro propósito que não o do próprio conhecimento histórico. Esse é tomado como essencial para esse indivíduo compreender o mundo em que vive; mesmo conferindo a ele uma função instrumental, não são os aspectos pedagógicos que se sobressaem. Os autores dão hoje mais atenção ao como se aprende, mas o ensino ainda parece ancorar-se sobretudo sobre o que se aprende.

\section{JUNTANDO AS VÁRIAS PONTAS}

O discurso didático possui característica próprias, que no caso de História exige uma modalidade de texto em que se entrecruzam narrativas, descrições, explicações e interpretações. Não tomamos narrativa aqui no sentido da velha história historicizante, da mera descrição factual, mas um tipo de texto em que uma dada trama se desenrola em um tempo determinado ou pelo menos referenciado, e por meio do qual é possível atribuir sentido à experiência de vida de outros grupos sociais ou indivíduos. A ação e os seus sujeitos são o centro desse discurso. No entanto, o discurso didático também exige exposições mais analíticas, em que os conceitos desempenham papel central. A tecitura desse discurso é bastante complexa, uma vez que é preciso combinar essas várias modalidades de texto dentro das limitações físicas que os livros impõem.

Resulta dessa "tensão" que os textos didáticos de história freqüentemente expressam uma visão teleológica da história, ou seja, constrói-se uma narrativa em que são "pinçados" apenas os eventos que sirvam para encadear uma argumentação explicativa de um dado processo histórico, que pressupõe um "final". O discurso didático de História, então, entrelaça frases que dizem respeito a conjunturas com outras referentes a acontecimentos específicos. Misturam-se, num curto trecho, a longa, a média e a curta duração, as estruturas e as conjunturas. O problema é que esse discurso destina-se a jovens que não dominam o pensamento histórico e estão exatamente a aprendê-lo. Ou seja, espera-se que os alunos já disponham daquilo que seria o resultado do seu estudo. Isso é ainda mais grave no Ensino Médio, por se 
considerar que se trabalha com alunos que já atingiram o pensamento formal, abstrato e, portanto, as aulas podem prescindir dos embasamentos da pedagogia e da psicologia da aprendizagem.

Essa característica intrínseca do discurso didático de História, mas que possivelmente não lhe é exclusiva, via de regra despreza os cuidados necessários tanto no tocante às temporalidades como com as particularidades históricas, porque privilegia quase sempre o geral (e não o particular) e a generalização. Compromete-se inevitavelmente, a historicidade das realidades assim apresentadas.

Essa tensão parece tanto mais grave quanto mais abrangente for o período compreendido pelo programa escolar. Uma alternativa que se tem apresentado a esse dilema é a tematização da História, que, entre outras vantagens, desobriga autores e professores a percorrerem largos espaços temporais durante o ano letivo. Ao se fazer os recortes temáticos, os objetos de estudo (e os sujeitos históricos) ficam muito mais circunscritos, podendo-se trabalhar mais detalhadamente com diversos grupos sociais, apreendendo as diferenças entre seus membros, e tornando possível trabalhar com a noção de múltiplas temporalidades (por exemplo: ao se trabalhar o processo de modernização econômica verificado no Brasil na passagem do século XIX para o XX, reconhecer as características da vida nas cidades do Rio de Janeiro, Belém e São Paulo, em uma fazenda de café no interior paulista, no arraial de Canudos, em um engenho baiano e em um seringal amazonense).

O grande "achado" da obra elaborada pelo grupo de Luciano de Privitellio reside nesse ponto: ao propor seções (unidades) organizadas em torno de um conjunto de questões (e não de um leque abrangente de assuntos), tornou possível que os textos ganhassem maior consistência histórica, quando comparados com os dos demais livros. As inovações metodológicas (tanto do ponto de vista a construção do conhecimento histórico, como da aprendizagem) contidas na obra, associadas às preocupações de ordem pedagógica, que levam em conta os percursos cognitivos que os alunos precisam seguir para conseguir chegar a determinado tipo de raciocínio ou conclusão, conferem à obra grandes diferenciais. Mas os autores não desconsideraram a prática dos professores, impondo-lhes algo 
muito diferente do que fazem há anos. Eles não propuseram uma obra temática, muito menos romperam com o eixo cronológico, característica da História escolar desde sempre. Preferiram estabelecer para cada seção um certo conjunto de anos, de modo que ao final do ano letivo os alunos possam ter uma visão geral do período contemporâneo (séculos XIX e XX). Ao preservarem essa estrutura, mantiveram referências mais seguras para os professores, considerando os saberes escolares há muito consolidados. Inovaram, sem promover rupturas. O livro encontrou assim grande receptividade entre os professores, conferindo à Santillana, a quem coube o desenho e a direção do projeto editorial, e fazendo uso do seu enorme poder comercial, a condição de líder de mercado.

No Brasil, o percurso foi bem diferente: as propostas curriculares lançadas em 2002 não encontraram eco nem na escola, nem na produção editorial, e a sua implantação tornou-se mais difícil. A tradição de uma certa concepção de conhecimento histórico escolar foi mantida, ainda que algumas mudanças de abordagem tenham sido verificadas. Apesar de mais ousada, a reforma brasileira redundou em resultados muito mais modestos, ainda que os avanços sejam expressivamente maiores do que o verificado no México, onde a estrutura educacional relativa ao Ensino Médio, descentralizada e fora do âmbito da SEP, impediu que o ensino de História pudesse se desenvolver segundo novas concepções.

Assim, duas reformas curriculares com grandes semelhanças sob diversos aspectos, desencadeadas simultaneamente, resultaram em duas configu-rações do ensino de História bastante distintas. Nosso trabalho possibilitou constatar como os livros didáticos jogaram peso decisivo para tal.

Essa situação é um bom exemplo do papel desempenhado pelos livros didáticos e como é fundamental procurar analisá-los dentro de um contexto o mais abrangente possível, para tentar compreender os diversos fatores que nele interferem e que ajudam a constituir a cultura escolar. Acreditamos que por meio da nossa pesquisa, que tornou possível compreender as motivações de tal situação, ficou evidenciado o profundo entrelaçamento entre as concepções de História e de ensino presentes nos livros didáticos. 


\section{FONTES}

ALONSO, Marisa et al. Historia Mundial Contemporánea. Serie Activa. Buenos Aires: Puerto de Palos Casa de Ediciones, 2002.

MOTA, Myriam B. e BRAICK, Patrícia. História: das Cavernas aos Terceiro Milênio. São Paulo: Moderna, 2002.

PASTOR, Marialba. Historia Universal. Bachillerato. México: Santillana, 2003.

PÉREZ MONROE, Julieta, LARA CISNEROS, Geraldo e ROMERO GARCIA, Juan Manuel. Historia Universal: de los orígenes de la modernidad a la crisis del mundo globalizado. México: Oxford, 2003.

PRIVITELLIO, Luciano et al. História del mundo contemporâneo - Desde la "doble revolución" hasta nuestro dias. Coleção Polimodal. Buenos Aires: Santillana, 2002.

VICENTNO, Cláudio e DORIGO, Gianpaolo. História para o Ensino Médio: história geral e do Brasil. São Paulo: Scipione, 2001.

\section{BIBLIOGRAFIA}

ABRAMOVAY, Miriam e CASTRO, Mary (Coord). Ensino Médio: múltiplas vozes. Brasília: UNESCO/MEC, 2003.

ABUD, Kátia. "Conhecimento histórico e Ensino de História: A produção de conhecimento histórico escolar" . In ANPUH, Encontros com a História no. 2 Sujeito na História: práticas e representações. São Paulo: EDUSC, 1999.

AGUILLAR PINEDA, Matilde. El sujeto cognoscente y I historia: hacia un replanteamiento de las formas de enseñanza. Universidad Pedagógica Nacional, 2003. Especialidad en estrategias de enseñanza y aprendizage de la Historia en la escuela.

APPLE, Michel. Trabalho docente e textos: Economia política das relações de classe e gênero em educação. Porto Alegre: ArtMed, 1995.

ARAUJO, Luciana Telles de. O uso do livro diático no ensino de História: depoimentos de professores de escolas estaduais de ensino fundamental situadas em São Paulo. Pontifícia Universidade Católica de São Paulo, 2001. Dissertação de mestrado.

BARBOZA, Ricardo et al. Educación Media y cultura adolescente - Desafios del siglo XXI. Buenos Aires: Academia Nacional de Educación, 2003.

BARCA, Isabel. O Pensamento Histórico dos jovens. Braga: Universidade do Minho/Centro de Estudos em Educação e Psicologia, 2000. 
BERGER Fo., RUY Leite. " Enseñanza media: los desafios de la inclusión”. In BRASLAVSKY, Cecilia. La educación secundaria. ¿Cambio o inmutabilidad? Buenos Aires: Santillana, 2001, pp. $337-372$.

BITTENCOURT, Circe Maria F. Pátria, civilização e trabalho. O ensino de História nas escolas paulistas (1917 - 1939). São Paulo: Loyola, 1990.

. Livro didático e conhecimento histórico: uma história do saber escolar. Faculdade de Educação da Universidade de São Paulo (FE-USP), 1993. Tese de doutoramento.

. "Propostas curriculares de História: continuidades e transformações". In: BARRETO, Elba de Sá B. (Org.). Os currículos do ensino fundamental para as escolas brasileiras. Campinas: Autores Associados; São Paulo: Fundação Carlos Chagas, 1998, pp.127 - 161.

BOURDIEU, Pierre. A economia das trocas simbólicas. São Paulo: Perspectiva, 1992.

(Org.). O saber histórico na sala de aula. São Paulo: Contexto, 2001.

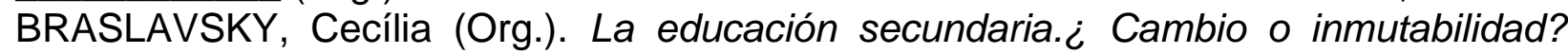
Análisis y debate de procesos europeos y latinoamericanos contemporáneos. Buenos Aires: Santillana, 2001.

BRUTER, Annie. "Histoire et identité:mariage indissoluble ou union passagère?" In: TUTIAUX-GUILLON, Nicole et NOURRISSON, Didier .Identités, memóires, consciense historique. Saint-Étienne: Université de Saint-Étienne, 2003.

BUENO, Maria Sylvia Simões. Políticas atuais para o Ensino Médio. Campinas, Papirus, 2000.

BREZO, Liliana "El Paragauy y la Argentina en los textos escolaresU una perspectiva bilateral de las representaciones del otro". Entrepasados, Ano VI, n¹2. 1997. pp. COMPLETAR

CAPELATO, Maria Helena R. Multidões em cena. Propaganda política no Varguismo e no Peronismo. Campinas: Papirus, 1998.

"Estado Novo: Novas Histórias...". In Freitas, Marcos Cezar (Org.). Historiografia Brasileira em Perspectiva. São Paulo: Contexto/USF, 1998, p. 183-213.

CARBONE, Graciela. Libros escolares: una introducción a su análisis y evaluación. Buenos Aires: Fondo de Cultura Económica, 2003.

CARDOSO, Ciro Flamarion. Um historiador fala de teoria e metodologia. Bauru: EDUSC, 2005.

CARNOY, Martin. Mundialização e Reforma na Educação. Brasília; UNESCO/IIIPE, 2002.

CARRETERO, Mario e VOSS, James F (Compls). Aprender y pensar la história.Buenos Aires, Amorrotu, 2004. 
CASTANÓN, Roberto e SECO, Rosa María. La Educación Média Superior en México. Una invitación a la reflexion. Mexico: Noriega, 2000.

CASTREJÓN DIEZ, Jaime. "El bachillerato". In: LATAPI SARRE, Pablo. (Coord.). Un siglo de educaión en México. México: Fondo de Estudios e Investigaciones Ricardo Zevada; Consejo Nacional para la Cultura y las Artes;Fondo de Cultura Económica, 1997, pp. 276 -297.

CERRI, Luis Fernando (Org.). O Ensino de História e a Ditadura Militar. Curitiba, Aos Quatro Ventos, 2003.

"Saberes históricos diante da avaliação do ensino: notas sobre os conteúdos de história nas provas do Exame Nacional do Ensino Médio". Revista Brasileira de História, n. 48, vol. 24, 2005, p. 213 - 231.

CHARTIER, Anne Marie e Hérbrard. Discursos sobre a leitura. São Paulo: Ática, 1995.

CHERVEL, André. "Historia das disciplinas escolares: reflexões sobre um campo de pesquisas". Teoria \& Educação. No. 2, p. 177 - 229, 1990.

e COMPÈRE, Marie-Madeleine. "Lês humanités dans l'Histoire de I'enseignement français". Histoire de l'educación, no. 74, p. 5-38, maio 1997.

CHEVALLARD, Yves. Transposition didatique. Grenoble: La Pensée Sauvage, 1991.

CHOPPIN, ALAIN. "Las políticas en libros escolares en el mundo". In PÉREZ SILLER, Javier e RADKAU GARCIA, Verena. Identidad en el imaginario nacional: reescritura y enseñanza de la Historia. Puebla: Instituto de Ciencias Sociales/Colegio de San Luiz; Brauschwerg: Institut Georg-Eckert, 1998, p. 169 180.

"Os manuais escolares na França e a formação do cidadão". Veritas, n. 43, Dez. 1998, p. $183-192$.

Les manuels scolaire - Histoire et actualité. Paris: Hachette, 1992.

"História dos livros e das edições didáticas: sobre o estado da arte". Educação e Pesquisa, vol. 30, n. 3, set/dez 2004.

CIAMPI, Helenice. A História pensada e ensinada: da geração das certezas à geração das incertezas. São Paulo: EDUC/PAPESP, 2000.

CITRON, Suzanne. Ensinar a história hoje: a memória perdida e reencontrada. Lisboa: Livros Horizonte, 1990.

COLL, César. Os conteúdos da Reforma. Porto Alegre: ArtMed, 1998. 
Constituição da República Federativa do Brasil. São Paulo: Imprensa Oficial do Estado, 2001.

CORDEIRO, Jaime. A História no centro do debate. São Paulo: Cultura Acadêmcia, 2000.

CUESTA FERNANDEZ, Raymundo. Sociogénesis de uma disciplina escolar: la Historia. Barcelona: Ediciones Pomares-Corridor, 1997.

CUNHA, Luiz Antonio. "As agências financeiras internacionais e a reforma brasileira do Ensino Técnico: a crítica da crítica”. In: ZIBAS, D. AGUIAR, M. e BUENO, M.S.S. O Ensino Médio e a reforma da Educação Básica. Brasília: Plano, 2002.

Declaração Mundial sobre Educação Para Todos. Plano de ação para satisfazer as necessidades básicas em aprendizagem. Brasília: UNICEF, 1990.

Diretrizes Curriculares Nacionais para o Ensino Médio. Brasília, MEC, 2002.

DELORS, Jacques. Educação Um tesouro a descobrir - Relatório para a UNESCO da Comissão internacional sobre Educação para o século XXI. São Paulo: Cortez; Brasília MEC/UNESCO, 2003.

DE ROSSI, Vera Lúcia e ZAMBONI, Ernesta.Quanto tempo o tempo tem. Campinas: Alínea, 2003.

DIAS, Maria de Fátima. A Invenção da América na cultura escolar. Universidade Estadual de Campinas, 1997. Tese de doutoramento.

Florianópolis, 2004.

História da América. Ensino, poder e identidade.

DOLZ, Joaquim e OLLANGNIER, Edmée. O enigma da competência em Educação. Porto Alegre: ArtMed, 2004.

EDUCACIÓN 2001. Revista Mexicana de Educación, n. 103, Deciembre 2003.

Educación Polimodal Acuerdo Marco. Ministério de la Cultura y Educación de la Nación. 1997.

ERETZA ROMERO, Rocio. Estratégias especificas que utiliza el adolescente ante textos de historia em el segundo nível de enseñanza secundaria. Universidad Pedagógica Nacional, 1999. Tesis de maestria.

FANFANI, Emilio Tenti (Compl) Educación média para todos. Los desafios de la democratización del acceso. Buenos Aires, Altamira, 2003.

FARICELLI, Marilu de Freitas. Conteúdo Pedagógico da História como disciplina escolar: exercícios propostos por livros didáticos de $5^{a}$ e $6^{a}$ série. Pontifícia Universidade Católica, 2005. Dissertação de mestrado. 
FERNANDÉZ, Ana Lia; FINOCCHIO, Silvia e FUMAGALLI, Laura. " Cambio de la educación secundaria en la Argentina". In BRASLAVSKY, Cecilia. La educación secundaria. ¿Cambio o inmutabilidad? Buenos Aires: Santillana, 2001, p. 337 372.

FERRO, Marc. História Vigiada. São Paulo: Martins Fontes, 1989.

FILMUS, Daniel et al. Cada vez más necesaria, cada vez más isuficiente. Escuela media y mercado de trabajo en écpocas de globalizacion. Buenos Aires, Santillana, 2001.

FINOCCHIO, Silvia (coord). Enseñar ciencias sociales. Buenos Aires: Troquel, 1997.

. "La enseñanza de la Historia em en el tercer ciclo de la EGB: una aproximación a lacomplexa realción de los contenidos". Entrepasados, Ano VI, n. 12, 1997, pp. $141-151$.

FONSECA, Selva Guimarães. Os caminhos da História Ensinada. Campinas: Papirus, 1983.

FONSECA, Thaís Nívia de Lima e. História e Ensino de História. Belo Horizonte: Autêntica, 2003.

FORQUIN, Jean-Claude. Escola e cultura escolar - As bases sociais e epistemológicas do conhecimento escolar. Porto Alegre: Arres Médicas, 1993.

FRANCO, Stella M. S. Luzes e sombras na construção da nação argentina: os manuais de história nacional (1868-1912). Bragança Paulista: EDUSF, 2003.

GARCIA MINGUEZ, J. y BEAS MIRANDA, M. (Compls). Libros de texto y construcción de materiales curriculares. Granada (Espanha): Proyecto Sur de Ediciones, 1995.

GASPARELLO, Arlette Medeiro. Construtores de Identidades: a pedagogia da nação nos livros didáticos da escola secundária brasileira. São Paulo, IGLU, 2004.

GATTI, Decio. A escrita escolar da História: Livro Didático e ensino no Brasil (1970 1990). Bauru/Uberlândia: EDUSC/ EDUFU, 2004.

GOODSON, Ivor. A construção social do currículo. Lisboa: EDUCA, 1997.

.Currículo: teoria e história. Petrópolis: Vozes, 1995.

GVIRTZ, Silvina. " Los contenidos de la escuela en la Argentina de hoy". In Las transformaciones de la educación en diez años de democracial. Buenos Aires: FLACSO, 1995.

HERY, Evelyne. Un siècle de leçons d'histoire enseignée au lycée 1870 - 1970. Rennes: Presses Universitaire de Rennes, 1999.

HÖFLING, Eloísa de Mattos. "Notas para a discussão quanto à implementação de programas de governo: em foco o PNLD". Educação e Sociedade, ano XXI, n. 70, abril de 2000, pp. $159-171$. 
HOLLANDA, GUY. Programas e Compêndios de História para o Ensino Secundário Brasileiro 1931 - 1956. Rio de Janeiro: INEP - Ministério da Educação e Cultura, 1957.

JACOMINI, Márcia A. "A escola e os educadores em tempo de ciclos de progressão continuada: uma análise das experiências no estado de São Paulo". Educação e Pesquisa, vol. 30, n. 3, 2004, $401-408$.

JOLY, Martine. Introdução à análise da imagem. Campinas: Papirus, 1996.

JOHNSEN, Egil B. Libros textos en el caliddoscopio. Barcelona: Ediciones PomaresCorridor, 1996.

JULIA, Dominique. "A cultura escolar como objeto histórico". Revista brasileira de História da Educação. No. 1, p. 9-43, 2001.

KARNAL, Leandro (Org.). História na sala de aula: conceitos, práticas e propostas. São Paulo: Contexto, 2003.

KOSHIBA, Luiz. A elaboração do conhecimento histórico (contribuição ao ensino de História). Faculdade de Ciências e Letras da Universidade Estadual Paulista Campus Araraquara, 1995, tese de Livre-Docência.

KUENZER, Acácia. Ensino Médio: construindo uma proposta para os que vivem do trabalho. São Paulo: Cortez,2002.

LAJOLO, Marisa. "Livro didático: um quase manual de usuário". Em Aberto, v. 16, n. 69, jan/mar. 1996.

LANZA, Hilda y FINOCCHIO, Silvia. La enseñanza de la História en la Argentina de hoy ( Tomo III). Os Aires: MiNo y Davill Editores, 1993.

LATAPI SRRE, Pablo (Coord.). Um siglo de educación en México. México: Fondo de Estudios e Investigaciones Ricardo Zevada; Consejo Nacional para la Cultura y las Artes;Fondo de Cultura Económica, 1997.

LAVILLE, Christian. "Além do conhecimento produzido e disseminado. Consciência histórica e educação histórica". Belo Horizonte: IX Encontro Regional da ANPUH, 2002 (extraído de www.fae.ufmg.br/ANPUH).

Lei de Diretrizes e Bases da Educação Nacional. São Paulo, Editora do Brasil, 1996.

Ley General de Educación. México: SEP, 1993.

LEITE, Miriam Moreira. O Ensino da História no Primeiro e no Ginásio. São Paulo: Cultrix, 1969.

LOMÔNACO, José Fernando B. A natureza dos conceitos: visões psicológicas. Instituto de Psicologia, Universidade de São Paulo, 1997. Tese de Livre Docência.

LOPES, Alice Ribeiro Casemiro. Conhecimento escolar: ciência e cotidiano. Rio de Janeiro: UERJ, 1999. 
LOURO, Margarida Felgueras. Pensar a História - repensar o seu ensino. Porto: Porto Editora, 1994.

LOYO, Marta. "La enseñanza de la Historia en México vista por medio de una muestra epresentativa de los textos de historia destinados a la Enseñanza Media básica". IN: Memorias del simposio de historiografia mexicanista. México: Comité Mexicano de Ciencias Históricas/ Gobierno del Estado de Morelos/Instituto de Investigaciones Históricas (UNAM), 1990, pp. 813 -835.

LUCINI, Marizete. Tempo, narrativa e ensino de História. Porto Alegre: Mediação, 2000.

MACHDO, Nilson J. Epistemologia e didática - as concepções de conhecimento e inteligência e pratica docente. São Paulo, Cortez, 2000.

MAFRA, Leila de A. e CAVALCANTI, Ednar de C. O Ensino Mèdio no Brasil: da ruptura do privilégio à conquista do direito. Brasília:INEP, 1992.

MARINA, José Antonio. Teoria da Inteligência criadora. Lisboa: Angrama, 1995.

MARTINEZ BONAFÉ, Jaume. Políticas del libro texto escolar. Madrid: Morata, 2002.

MARTINEZ, Raul. "Orígenes de la educación pública en México". IN: SOLANA, Fernando et al. Histori de la educación pública en México. México: Fondo de Cultura Económica, 1997.

MELLO, Paulo Eduardo D. de. Vestibular e Currículo: o Saber Histórico Escolar e os Exames Vestibulares da FUVEST. Faculdade de Educação da Universidade de São Paulo, 2000. Dissertação de mestrado.

MENDONÇA, Nadir Doingues. O uso dos conceitos. Petrópolis: Vozes, 1994.

MESKENAS, Paulo. A produção do livro didático: sua relação com o Estado, autor e editor. Faculdade de Educação da Universidade de São Paulo, 1992, Dissertação de mestrado.

MINISTÉRIO DA EDUCAÇÃO. Parâmetros Curriculares Nacionais do Ensino Médio. Brasília: MEC, 2002.

MINISTÉRIO DA EDUCAÇÃO. Ensino das Humanidades: A modernidade em questão. Cadernos SENEB. São Paulo: Cortez, Brasília, Secretaria Nacional de Educação Básica, 1991.

MONIOT, Henri. "Há aprendizagem histórica?".In Moniot, H. Didactique de l'histoire. Paris: Natan, 1993, pp. 155-165.

MONTER, Elvira V. La reforma curricular de 1993 y su impacto en la enseñanza en la escuela secundaria. Universidade Pedagógica Nacional (México), 1999.

MORIN, Edgar. A cabeça bem feita: repensar a reforma, repensar o pensamento. Rio de Janeiro: Bertrand Brasil, 2001. 
MUNAKATA, Kazumi. Produzindo livros didáticos e paradidáticos.Pontifícia Universidade Católica de São Paulo, 1997. Tese de doutoramento.

. "investigações acerca dos livros escolares no Brasil: das idéias à materialidade". In Memória Del VI Contreso Iberoamericano de Historia de la Educación Latinoamericana, San Luis Potosoi (versão em CD-ROM), 2003.

. "Histórias que os livros didáticos contam depois que acabou a ditadura no Brasil". IN: FREITAS, Marcos Cezar. Historiografia brasileira em perspectiva. São Paulo, Contexto, 2001.

Livro didático: produção e leitura". In Abreu, Marcia (Org.) Leitura, História e História da leitura. Campinas: Mercado de Letras, 2000, 271- 594.

Núcleo de Conoscimientos y Formación Básicos que debe proporciar el bachillerto de la UNAM. UNAM, 2000.

NAPOLITANO, Marcos F. " História Contemporânea: pensando a estranha história sem fim”. In Karnal, L. (Org.). História na sala de aula. São Paulo: Contexto, 2003. P. $163-184$.

NUNES, Silma do Carmo. Concepções de mundo no ensino de História. Campinas: Papirus, 1996.

OSSENBACH, Gabriela e SOMOZA, Miguel (Eds.). Los manuales escolares como fuente para la História de la Educación en America Latina. Madrid: Universidad Nacional de Educación a Distancia, 2001.

PAIVA, Eduardo França. História \& Imgem. Belo Horizonte, Autêntica, 2002.

Parâmetros Curriculares Nacionais do Ensino Médio. Brasília: MEC, 2002.

PENIN, Sonia. Aula: espaço de conhecimento, lugar de cultura. Campinas: Papirus, 1994.

PERES, Sebastião. O Ensino de História e as Reformas Educacionais no Mercosul. Universidade Federal de Minas Gerais, 2001. Tese de doutoramento.

PÉREZ SILLER, Javier e RADKAU GARCIA, Verena (Coords). Identidad en el imaginario nacional: reescritura y enseñanza de la historia. Puebla: Instituto de Ciencias Sociales/Colegio de San Luiz; Brauschwerg: Institut Georg-Eckert, 1998.

PERRENOUD, Philippe. Construir as competências desde a escola. Porto Alegre: ArtMed, 1999.

PINSKY, Jaime. O ensino da História e a criação do fato. São Paulo: Contexto, 1988.

PRADO, Maria Ligia C. América Latina no século XIX: Tramas, Telas e Textos.São Paulo: EDUSP, 1999.

. "Repensando a História comparada da América Latina". Revista de História, no. 153, 20. Sem. 2005. 
PRIETO, Ana Maria. "La educación Media Superior". In: BERTUSSI, Guadelupe T. Anuário Educativo Mexicano. México: Universidad Pedagógica Nacional, 2001.

PRIORI, Angelo. "A concepção de história nos manuais didáticos: uma releitura". História \& Ensino, Vol. 8, 2002, pp. 19 -25.

PRIVITELLIO, Luciano de. "Los otros en la historia escolar: las naciones estranjeras en los manuales de historia argentina entre 1956 e 1989." Etrepasados, nº. 15, 1998, pp. $129-149$.

PROENÇA, Maria Cândida. Ensinar/aprender história - questões de didática aplicada. Lisboa: Livros Horizonte, 1990.

RICCI, Claudia. "A academia vai ao ensino de $1^{\circ}$ e $2^{\circ}$. graus". Revista Brasileira de História. V. 19, no. 19, p. 135-142, 1989/1990.

ROMERO, Luis Alberto. La Argentina en la escuela. La idea de nación en los textos escolares. Buenos Aires: Siglo XXI, 2004.

ROMERO, Rocio Eretza. Estratégias específicas que utiliza el adolescente ante textos de historia en el segundo nível de ensñanza secundaria. Universidade Pedagógica Nacional (México), 1998. Tesis de licenciatura en Psicologia Educativa.

RÜSEN, Jörn. Razão histórica. Teoria da história: os fundamentos da ciência histórica. Brasília: UnB, 2001.

SACRISTÁN, Gimeno. "Materiales y textos: contradiciones de la democracia cultural". In Garcai Minguez, J. e Beas Miranda, M. Libros texto como construcción de materiales curriculares. Granada: Proyecto Sur de Ediciones, 1995.

2000.

. O Currículo: uma reflexão sobre a prática. Porto Alegre: ArtMed,

SCHMIDT, Maria Auxiliadora e CAINELLI, Marlene. Ensinar História. São Paulo: Scipione, 2004.

SECRETARIA DE EDUCACIÓN PÚBLICA. Artículo $3^{\circ}$ Constitucional y Ley General de Educación. 1993.

SECRETARIA DE EDUCACIÓN PÚBliCA. Perfil de la Educación en México. México: SEP, 1999.

SEGAL, Andre. "Pour une didactique de la durée. In: MONIOT, Henri. Enseigner I'histoire - des manuels à la mémoire. Berne: Peter Long, 1984, pp. 93 - 111.

SILVA, Marco Antonio. "Do museu à sala de aula" . Projeto História, SP, v. 20, p. 253 $267,2000$.

SILVA, Tomaz Tadeu. Documentos e Identidade: uma introdução às teorias do currículo. Belo Horizonte, Autêntica, 2003.

SILVA, Vitória R. "O ensino de História da América no Brasil". Diálogos, v.8, no. 2, p.83-104, 2004. 
SIMAN, Lana Mara de C. e FONSECA, Thaís Nívea de L. (Orgs.). Inaugurando a História e construindo a nação - Discursos e imagens no ensino de História. Belo Horizonte, Autêntica, 2001.

SOLÉ, Isabel. Estratégias de leitura. Porto Alegre:ArtMed, 1998.

TIRAMONTI, Guilhermina, BRASLAVSKY, Cecília y FILMUS, Daniel (Compls.). Las transformaciones de la educación en diez años de democracia. Buenos Aires: FLACSO, 1995.

WALTY, Ivete Lara C. Palavras e imagens: leituras cruzadas. Belo Horizonte, Autêntica,2001.

ZIBAS, D. AGUIAR, M. e BUENO, M.S.S. O Ensino Médio e a reforma da Educação Básica. Brasília: Plano, 2002.

ZIEGLER, Sandra. De las políticas curriculares a las resignificaciones de los docentes: una análisis de la reforma de los años'90 en la Provincia de Buenos Aires a partir de la recepción de los documentos curriculares por parte de los docentes. FLACSO, 2001. Tesis de doctoramento. 